
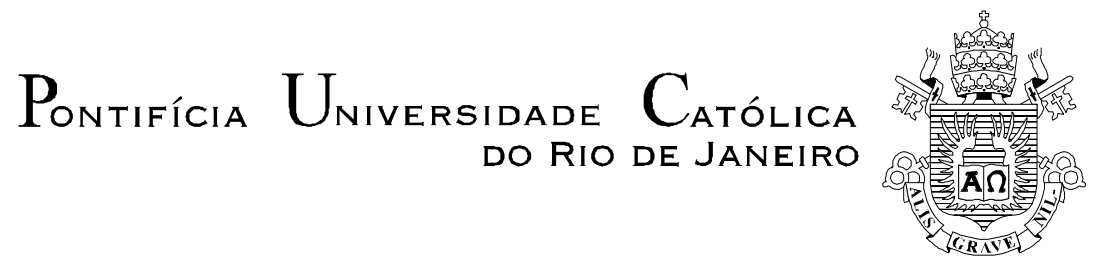

Nicholas Pinho Ribeiro

\title{
Sistemas de Inferência Fuzzy Hierárquicos Aplicados à Caracterização da Confiabilidade Humana
}

\section{Dissertação de Mestrado}

Dissertação apresentada como requisito parcial para obtenção do título de Mestre pelo Programa de PósGraduação em Engenharia Elétrica da PUC-Rio.

Orientadora: Profa. Marley Maria Bernardes Rebuzzi Vellasco Co-orientador: Prof. Ricardo Tanscheit 


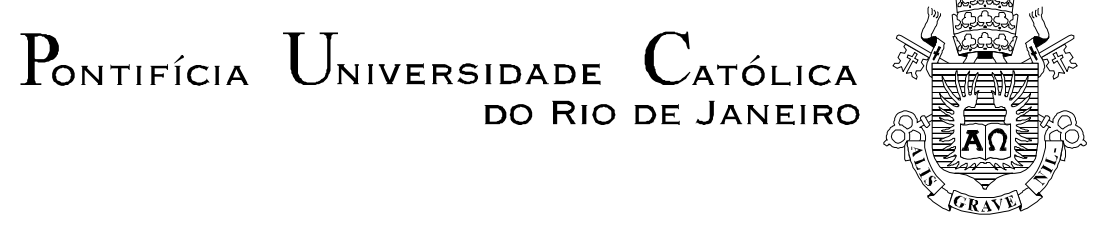

Nicholas Pinho Ribeiro

\section{Sistemas de Inferência Fuzzy Hierárquicos Aplicados à Caracterização da Confiabilidade Humana}

Dissertação apresentada como requisito parcial para obtenção do título de Mestre pelo Programa de PósGraduação em Engenharia Elétrica da PUC-Rio. Aprovada pela Comissão Examinadora abaixo assinada.

Profa. Marley Maria Bernardes Rebuzzi Vellasco

Orientadora

Departamento de Engenharia Elétrica - PUC-Rio

Prof. Ricardo Tanscheit

Co-orientador

Departamento de Engenharia Elétrica - PUC-Rio

Profa. Dilza de Mattos Szwarcman

UEZO

Prof. Jesús Domech Moré

Universidade Estácio de Sá

Profa. Karla Tereza Figueiredo Leite

UEZO

Prof. José Eugênio Leal Coordenador Setorial do Centro

Técnico Científico - PUC-Rio

Rio de Janeiro, 14 de Maio de 2014 
Todos os direitos reservados. É proibida a reprodução total ou parcial do trabalho sem autorização da universidade, do autor e da orientadora.

\section{Nicholas Pinho Ribeiro}

Graduou-se em Engenharia Industrial pela Pontifícia Universidade Católica do Rio de Janeiro (PUC-Rio) em 2010.

Ficha Catalográfica

Ribeiro, Nicholas Pinho

Sistemas de inferência fuzzy hierárquicos aplicados à caracterização da confiabilidade humana / Nicholas Pinho Ribeiro; orientadora: Marley Maria Bernardes Rebuzzi Vellasco - 2014. 256 f. : il. (color.) ; $30 \mathrm{~cm}$

Dissertação (mestrado) - Pontifícia Universidade Católica do Rio de Janeiro, Departamento de Engenharia Elétrica, 2014. Inclui bibliografia

1. Engenharia elétrica - Teses. 2. Confiabilidade Humana. 3. Lógica Fuzzy. 4. Inteligência Computacional. 5. Sistemas de Inferência Fuzzy Hierárquicos. 6. Erros Humanos. 7. Caracterização. 8. Performance Shaping Factors. I. Vellasco, Marley Maria Bernardes Rebuzzi. II. Pontifícia Universidade Católica do Rio de Janeiro. Departamento de Engenharia Elétrica. III. Título.

CDD: 621.3 


\section{Agradecimentos}

À minha mãe, que teve participação importantíssima na decisão de cursar o mestrado, além da lembrança de todo o apoio e valores passados, sem os quais este trabalho não seria possível.

À minha orientadora Professora Marley, pelo apoio, incentivo, confiança e parceria para a realização deste trabalho.

Ao meu co-orientador Professor Ricardo, pela disponibilidade e importantes contribuições.

Ao meu pai, pelo constante apoio e motivação para que eu concluísse esta etapa.

À minha amiga Manoela, por ajudar sempre que precisei, colocando seus conhecimentos à disposição.

Aos colegas da PUC-Rio que fizeram parte desta jornada, seja freqüentando as mesmas aulas, formando grupos de estudo, ou convivendo no mesmo laboratório de pesquisa.

Aos funcionários da PUC-Rio que viraram amigos, cuja simpatia transformou situações de dia-a-dia em memórias valiosas.

A todos os amigos e familiares que, de uma forma ou de outra, me estimularam e me ajudaram.

Aos professores que participaram da comissão examinadora, por dedicar seu tempo e expertise na avaliação deste trabalho.

À CAPES, e à PUC-Rio, pelos auxílios, infra-estrutura, e oportunidades maravilhosas, imprescindíveis para que este trabalho fosse realizado. 


\section{Resumo}

Ribeiro, Nicholas Pinho. Vellasco, Marley Maria Bernardes Rebuzzi. Sistemas de Inferência Fuzzy Hierárquicos Aplicados à Caracterização da Confiabilidade Humana. Rio de Janeiro, 2014. 256p. Dissertação de Mestrado - Departamento de Engenharia Elétrica, Pontifícia Universidade Católica do Rio de Janeiro.

A maioria dos estudos existentes em controle de qualidade de processos focam no desempenho de máquinas e ferramentas. Assim, estes já contam com bons métodos para serem controlados. Contudo, erros humanos em potencial estão presentes em todos os processos industriais que contenham a relação homemmáquina, fazendo com que a necessidade de se avaliar a qualidade do desempenho humano seja de igual importância. A abordagem para se avaliar quão suscetível à falha humana estão tais processos baseiam-se em probabilidades de erro, supondo que o desempenho humano funciona da mesma maneira que o desempenho de máquinas, ou em PSFs (Performance Shaping Factors), variáveis representativas de características de desempenho humano. Embora esta última abordagem seja mais eficiente, ainda existem críticas a sua falta de contextualização: tais características são avaliadas separadamente uma das outras, e independentemente da tarefa que o operador esteja realizando. Sistemas de Inferência Fuzzy (SIFs) permitem que variáveis lingüísticas sejam avaliadas em conjunto, isto é, passa a ser possível criar um modelo que assimile as nuances da variação do comportamento de um PSF concomitantemente com a alteração de outro PSF. Dessa forma, a caracterização da confiabilidade humana, considerando que diversos PSFs afetam no desempenho dos demais, pode ser satisfeita ao se fazer uso de SIFs interligados seqüencialmente - SIFs hierárquicos. Para se contextualizar a caracterização da confiabilidade humana por tarefa realizada, necessita-se que os PSFs pertinentes a cada determinada tarefa sejam medidos novamente e realimentados ao sistema (desenvolvido nesta dissertação). O SIF geral (composto por nove camadas de SIFs hierárquicos) foi testado com dados hipotéticos e dados reais de operadores e tarefas de uma empresa do setor elétrico brasileiro. Os resultados encontrados foram satisfatórios e evidenciaram que a Lógica Fuzzy, na forma de SIFs hierárquicos, pode ser utilizada para caracterizar a confiabilidade humana, com a vantagem de fazê-lo enquanto seu contexto é considerado. 


\section{Palavras-chave}

Confiabilidade Humana; Lógica Fuzzy; Inteligência Computacional; Sistemas de Inferência Fuzzy Hierárquicos; Erros Humanos; Caracterização; Performance Shaping Factors. 


\section{Abstract}

Ribeiro, Nicholas Pinho. Vellasco, Marley Maria Bernardes Rebuzzi (Advisor). Hierarchical Fuzzy Inference Systems Applied to Human Reliability Assessment. Rio de Janeiro, 2014. 256p. MSc. Dissertation - Departamento de Engenharia Elétrica, Pontifícia Universidade Católica do Rio de Janeiro.

Most of existing studies in quality control focus on machinery performance. There are effective and advanced control methods to deal with that. However, potential human errors are present in every industrial process operated by humans. Therefore, evaluating the quality of human performance becomes as important as evaluate machinery's. The approach to evaluate how much processes are susceptible to human error are based on error probabilities, by assuming that human performance is similar to machinery performance, or on PSFs (Performance Shaping Factors) - variables representing human features. Although this based approach is more efficient, there are still criticisms about its lack of context awareness: those features are evaluated separately from one another, and regardless of which task the employee is performing. Fuzzy Inference Systems (FISs) allow linguistic variables to be evaluated simultaneously, thus making it possible to develop a method that gathers the nuances of behavioral changes of a PSF whilst another PSF varies. With this method, and considering that different PSFs affect the performance of others, human reliability can be assessed through the use of sequentially interconnected FISs - Hierarchical Fuzzy Inference Systems. In order to contextualize this assessment by tasks, each of the PSFs that affects each task will have to be measured and fed into the system (as developed within this dissertation) once per task and per employee. The main FIS (which contains nine layers of hierarchical FISs) was tested by using both hypothetical and real data from operators and tasks of a Brazilian electricity company. Results were satisfactory and attested that Fuzzy Logic, in the form of hierarchical FISs, can be used to assess human reliability, with the advantage of also taking the context into account. 


\section{Keywords}

Human Reliability; Fuzzy Logic; Computational Intelligence; Hierarchical Fuzzy Inference Systems; Human Errors; Assessment; Performance Shaping Factors. 


\section{Sumário}

1. Introdução 14

1.1. Motivação 14

$\begin{array}{ll}\text { 1.2. Objetivos } & 16\end{array}$

$\begin{array}{lr}\text { 1.3. Estrutura da Dissertação } & 17\end{array}$

2. Fundamentos 18

2.1. Confiabilidade Humana 18

2.1.1. Avaliação Tradicional e Fatores de Desempenho Humano 18

2.1.2. Tipos de Erro 27

3. Metodologia 32

3.1. Generalização da Metodologia 32

3.2. PSFs Avaliados 33

3.3. Agrupamento e Estruturação dos SIFs Hierárquicos 41

3.4. Regras dos Sistemas de Inferência Fuzzy Hierárquicos 53

3.4.1. Etapa Informação $\quad 54$

3.4.2. Etapa Decisão 85

3.4.3. Etapa Ação 125

4. Estudos de Caso 170

4.1. Contextualização de PSFs com Tarefas 170

4.2. O Projeto ConfHIA 171

4.3. Implementação 171

4.4. Tarefas Avaliadas 172

4.5. Casos Hipotéticos (para Validação do Modelo) 173

4.6. Casos com Tarefas Reais 176

5. Conclusões e Trabalhos Futuros 181

5.1. Conclusões 181

5.2. Trabalhos Futuros 182 
Referências Bibliográficas

Apêndice A - Tarefas e PSFs Pertinentes 


\section{Lista de Figuras}

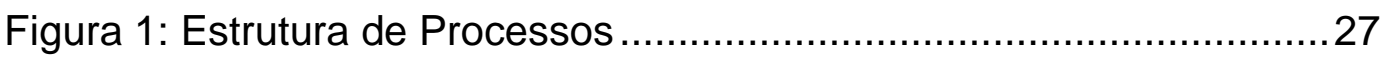

Figura 2: Diagrama de blocos do modelo proposto.................................32

Figura 3: Exemplo de SIF hierárquico do primeiro nível........................... 42

Figura 4: Exemplo de SIF hierárquico do segundo nível......................... 43

Figura 5: Agrupamento de SIFs hierárquicos do primeiro ao quinto

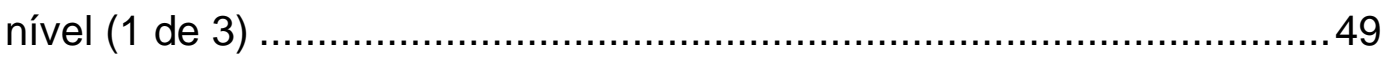

Figura 6: Agrupamento de SIFs hierárquicos do primeiro ao quinto

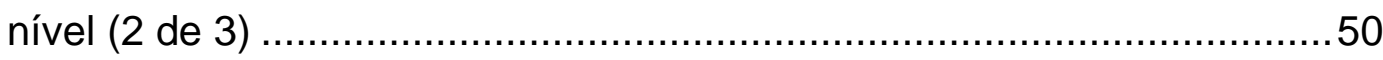

Figura 7: Agrupamento de SIFs hierárquicos do primeiro ao quinto

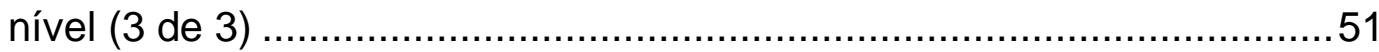

Figura 8: Agrupamento de SIFs hierárquicos remanescentes do primeiro nível....

Figura 9: Agrupamento dos SIFs hierárquicos de terceiro e quinto nível até o último nível.

Figura 10: Gráfico representativo do universo de valores e dos conjuntos das variáveis fuzzy do sistema. 


\section{Lista de Tabelas}

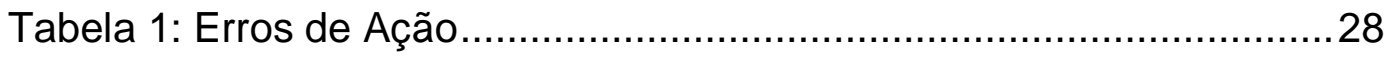

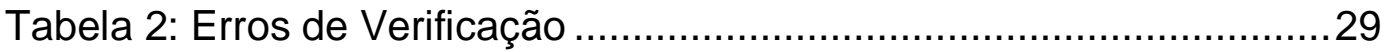

Tabela 3: Erros de Recuperação.............................................................29

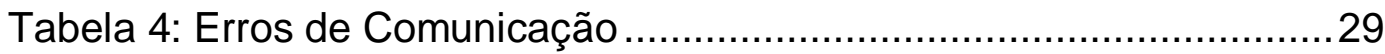

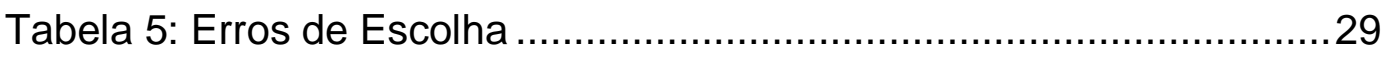

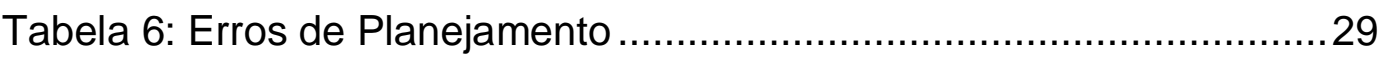

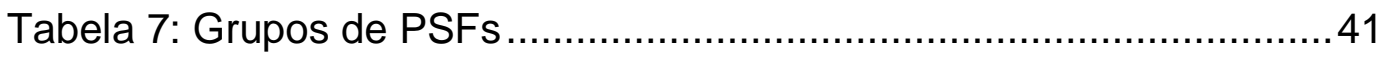

Tabela 8: Agrupamento dos PSFs em SIFs de 1ำ nível ............................48

Tabela 9: Desempenho dos PSFs do operador .................................176

Tabela 10: Possibilidades de Erro do operador selecionadopara as primeiras tarefas do Procedimento para Execução deIntervenção

Tabela 11: Possibilidades de Erro do operador selecionado para as tarefas do Procedimento para Implantação de Documentação

Tabela 12: Possibilidades de Erro do operador selecionado para as cinco primeiras tarefas do Procedimento para Registros de Operação. 178 Tabela 13: Possibilidades de Erro do operador selecionado para as cinco primeiras tarefas do Procedimento para Operação em Regime Normal

Tabela 14: Possibilidades de Erro do operador selecionado para as cinco primeiras tarefas do Procedimento para Programação de Intervenção em Urgência ou Emergência

Tabela 15: Possibilidades de Erro do operador selecionado para as cinco primeiras tarefas do Procedimento para Recomposição 180

Tabela 16: Associação de tarefas do Procedimento para Execução de Intervenção com PSFs pertinentes.

Tabela 17: Associação de tarefas do Procedimento para Implantação de Documentação com PSFs pertinentes

Tabela 18: Associação de tarefas do Procedimento para Implantação de Documentação com PSFs pertinentes 224

Tabela 19: Associação de tarefas do Procedimento para Operação 
em Regime Normal com PSFs pertinentes 233

Tabela 20: Associação de tarefas do Procedimento para

Programação de Intervenção em Urgência ou Emergência com

PSFs pertinentes

Tabela 21: Associação de tarefas do Procedimento para

Recomposição com PSFs pertinentes. 256 


\section{1. \\ Introdução}

\section{1. Motivação}

Sabe-se que o erro humano é um fator intrínseco às relações homemmáquina e às interpessoais, e que a eficiência humana é variável, ambos dependentes de diversos outros fatores, além da qualificação, capacitação, nível de treinamento ou de motivação do empregado (Lorenzo, 2001) e (Szwarcman, 2009). Apesar disso, geralmente as estratégias de gestão priorizam a aplicação de recursos em estudos de confiabilidade de equipamentos (Federal Aviation Administration, 2013) e de otimização de processos através da automação em tempo real (Jinzhu, 2012). De forma geral, são desenvolvidas essas linhas para depois se adaptar o homem ao processo, quando na realidade dever-se-ia pesquisar também a confiabilidade e o desempenho humanos para, na medida do possível, adaptar o equipamento e o ambiente ao homem.

Erros humanos foram historicamente tidos como aleatórios (Swain, 1990): a qualidade da execução de tarefas por uma pessoa era tratada da mesma forma que a qualidade da execução por máquinas. Tarefas humanas eram modeladas por probabilidades de erros. Isto significa que a causa desses erros eram ignoradas, dada a dificuldade em identificá-las. Porém, é imprescindível compreender que um erro humano, necessariamente, tem uma causa e essa tem de ser bem definida. O motivo pelo qual um erro humano ocorreu pode ter inúmeras naturezas: deslize ao executar um movimento, distração ao receber uma informação não clara ou falta de experiência ao tomar uma decisão importante.

É esperado que, eventualmente, um operador cometa um erro e o processo que ele esteja operando venha a falhar (sendo descontinuado provisória ou permanentemente). Ao afetar o custo de produção (Jallon, 2011), os acidentes de trabalho levam empresas a aumentar preços, o que pode prejudicar a sua competitividade, a sua imagem, e o seu faturamento. $\mathrm{O}$ adicional pago a trabalhadores em condições perigosas, o pagamento de altos prêmios de seguros, 
as ações por danos morais, a perda de certificados de qualidade e as multas ambientais prejudicam severamente o resultado operacional das empresas. Muitas vezes tenta-se diminuir o impacto dessas falhas no faturamento/desempenho das empresas/indústrias fazendo uso de seguradoras, ou de simples alocação de capital a fim de cobrir tais acontecimentos. Amenizar o impacto financeiro é apenas uma maneira de lidar com o problema, mas esta é uma abordagem pouco eficiente, já que não impede que outras falhas ocorram e nem que a mesma falha ocorra novamente.

Os modelos existentes de caracterização da confiabilidade humana a estudam no nível de processos - o nível mais alto de estruturação das seqüências de etapas internas do funcionamento de uma indústria (Domech, 2007) - e no nível de procedimentos (Szwarcman, 2010). Considera-se que essa estrutura é composta de tarefas seqüenciais que compõem um procedimento, e estes por sua vez compõem um processo. Essa avaliação é válida, e tem mostrado avanços importantes no estudo da confiabilidade humana, porém ficou exposta a críticas ao não considerar que o contexto de cada tarefa varia, ainda que pertencente a um mesmo processo. Assim, se o contexto dos processos e procedimentos for bem avaliado, as causas dos erros humanos podem passar a ser conhecidas e bem definidas. A partir do conhecimento da causa de cada falha torna-se possível mitigá-la, antes que necessariamente uma falha em potencial ocorra, seja ela causada por um fator interno ao operador, externo, cognitivo, de personalidade, de stress psicológico ou de stress fisiológico.

Deseja-se tratar a possibilidade de ocorrência de erros humanos como situações/eventos onde todas as variáveis são conhecidas. Um dado evento, se possuir um número suficientemente grande de fatores desconhecidos (ou imensuráveis) o influenciando, pode ser modelado por alguma distribuição de probabilidade, uma vez que seja considerado aleatório. Um dos exemplos mais básicos, o lançamento de um dado, é considerado aleatório: a probabilidade de "dar um número" é de 16,67\%. Porém, se todas as variáveis em questão forem analisadas, poder-se-ia prever o resultado. Se souber qual face está para cima, qual a velocidade que o dado será lançado, o ângulo de lançamento, o material da superfície em que irá aterrissar, o ângulo desta superfície, a altura da qual o dado foi lançado em relação à superfície e o tamanho das arestas do dado, o evento passará a ser previsível e o resultado poderia ser previsto. Naturalmente, essa 
precisão é tão grande quanto o número de variáveis analisadas, e tão real quanto for possível medir cada uma delas.

A utilização de Lógica Fuzzy para a avaliação e caracterização da confiabilidade humana é inédita na literatura. Os modelos citados, (Domech, 2007) e (Szwarcman, 2010), utilizam números fuzzy em uma determinada etapa (agregação da opinião de especialistas), mas não um sistema de inferência. Este trabalho propõe uma abordagem que diminui a incerteza inerente ao estudo da caracterização da confiabilidade humana, pois faz uso de sistemas de inferência fuzzy, capazes de absorver e tratar correta e eficientemente a imprecisão intrínseca às características humanas que devem ser estudadas. Além disso, a abordagem proposta é adaptável: pode ser aplicada a qualquer empresa, mediante a eventual modificação dos fatores levados em consideração.

Acidentes reais e de grande escala poderiam ter sido evitados se a confiabilidade humana tivesse sido alvo de mais aplicações práticas (Shappell, 2001). Analogamente, espera-se que após a instalação em empresas da metodologia aqui desenvolvida, acidentes futuros sejam de fato evitados. Não se pretende prever o momento exato em que um operador irá cometer um erro catastrófico. $\mathrm{O}$ interesse reside em identificar quais situações estão mais sujeitas a erros humanos e por qual motivo, para que possam ser alteradas antes que o erro venha a ocorrer. Ao se identificar que uma tarefa tem alta possibilidade de falha, já se sabe onde alocar recursos investimentos e efetuar mudanças. $\mathrm{O}$ segundo passo é descobrir a causa da falha em potencial, de maneira que passa a identificar a etapa do processo que deve ser modificada e o que nela deve ser aprimorado.

\section{2.}

\section{Objetivos}

O objetivo principal desta dissertação é identificar quais tarefas de uma empresa estão mais sujeitas a falhas humanas, para que gestores sejam informados, com antecedência, sobre quais áreas estão mais críticas no que diz respeito à segurança e à eficiência de projeto.

Secundariamente, tem-se o objetivo de evidenciar quais tipos de erros humanos se relacionam com cada possível falha (Hendrickson, 2010), uma vez que as metodologias existentes não permitem que as causas dos erros sejam 
identificadas, isto é, não se sabe qual tipo de erro ocorreu durante a falha da tarefa. Para tanto, foi necessário reavaliar a confiabilidade humana, propondo uma abordagem inédita para caracterizá-la. A caracterização da confiabilidade humana proposta neste trabalho é realizada no nível de tarefas, o nível mais baixo possível de ser alcançado na prática.

\section{3. \\ Estrutura da Dissertação}

Esta dissertação possui mais quatro capítulos, que são apresentados a seguir.

No Capítulo 2 são explicados os fundamentos nos quais este trabalho se baseia. Apresenta-se um levantamento bibliográfico sobre confiabilidade humana, bem como as maneiras existentes para agrupar os diferentes erros humanos em tipos, que facilitam o entendimento e o estudo.

No terceiro capítulo, o modelo proposto é exposto, uma nova maneira de caracterizar a confiabilidade humana é sugerida, permitindo que esta seja analisada em níveis mais baixos. Deseja-se que as causas das falhas sejam identificadas, portanto é necessário que o modelo suporte em detalhe os procedimentos considerados.

O quarto capítulo apresenta um estudo de caso, com uma empresa real do setor elétrico brasileiro, além de situações hipotéticas utilizadas apenas para validar o modelo proposto. Ainda no Capítulo 4, os resultados são avaliados, de forma que a eficiência do modelo possa ser julgada.

No quinto e último capítulo o trabalho é concluído e são discutidos possíveis trabalhos futuros: o que deve ser alterado para que o modelo continue pertinente quando aplicado a diferentes empresas, e quais outras áreas do conhecimento, além da Confiabilidade Humana, podem fazer uso de modelos similares. 


\section{2. \\ Fundamentos}

\section{1. \\ Confiabilidade Humana}

\subsection{1. Avaliação Tradicional e Fatores de Desempenho Humano}

Foi realizado um levantamento bibliográfico de diferentes abordagens para se avaliar a confiabilidade humana. A avaliação da confiabilidade humana surge da avaliação probabilística da segurança, uma vez que o erro humano é intrínseco aos acidentes de trabalho. Embora a necessidade de considerar o erro humano nas avaliações probabilísticas da segurança (PSA - Probabilistic Safety Assessment) venha da engenharia, pois esta é que está interessada em minimizá-los, o conceito inicial é herdado da ciência do comportamento, e esta não pode ser ignorada (Hollnagel, 2005). Naturalmente, ao se utilizar o termo "erro humano", não se está apontando que a responsabilidade do erro em si é da pessoa (ou colaborador, mais especificamente, pelo fato do estudo ter como alvo empresas e indústrias) relacionada ao erro. $\mathrm{O}$ erro pode ter sido causado por uma omissão de uma ação, ou tomada de uma ação, num momento errado que indiretamente afetou a segurança (John A. Volpe - National Transportation Systems Center, 2003).

A avaliação da confiabilidade humana pode ser resumida em quatro importantes etapas:

1. Avaliação qualitativa de problemas dos fatores humanos: analisar o impacto do ambiente de trabalho e da tecnologia atual no desempenho humano. Deve-se levar em consideração todas as regras de operação; procedimentos; informações disponíveis; e se possível, entrevistas com os colaboradores envolvidos com o processo. O objetivo é identificar as principais fontes de risco de erro humano. 
2. Pesquisa nos bancos de dados: quando existentes, identificar quais informações de erros passados são relevantes para a quantificação de possíveis erros futuros

3. Quantificação: desenvolver estimativas quantitativas da possibilidade de cada ação humana em questão ocorrer. Essa etapa pode fazer uso de especialistas, que muitas vezes são necessários por sua capacidade de prover boas estimativas de quão relevante é uma ação, em casos em que tal informação não está disponível em bancos de dados. Ou simplesmente fazer ajustes nas informações já existentes, para que ela possa ser adaptada e utilizada no processo a ser considerada.

4. Documentação: permitir revisão e compreensão/entendimento futuro e aprofundado dos detalhes da quantificação. É ideal que todos resultados sejam bem documentados, de maneira que possam formar novas bases de estimativas (ou complementar as já existentes), para que a avaliação da confiabilidade humana possa ser aprimorada a cada estudo/aplicação.

Segundo Domech (2004), na teoria convencional, a confiabilidade de um sistema é definida como a probabilidade que tem o sistema para desempenhar funções predefinidas (sem falhas) num tempo predeterminado sob condições préespecificadas. A teoria convencional de confiabilidade é baseada em duas suposições:

- A probabilidade que falhe o comportamento do sistema está inteiramente caracterizada num contexto de medidas de probabilidade.

- O sistema demonstra somente dois estados nítidos: funcionando ou falhado; em qualquer instante, o sistema se encontra em um dos dois estados.

Segundo Fujita (1992) a análise de confiabilidade humana iniciou-se nos anos 50. Um dos primeiros estudos realizados, baseado na análise convencional de confiabilidade, foi feito no Sandia National Laboratory nos Estados Unidos, envolvendo sistemas de armas nucleares. Foi desenvolvido um banco de dados de 
confiabilidade humana no Instituto Americano de Pesquisa para o Armazenamento de Dados (American Institute Research Data Store - AIR) até o início dos anos 60. Nos Estados Unidos, durante um simpósio em 1964, foi apresentado o estado da arte dos métodos de Confiabilidade Humana, sendo a técnica THERP(Technical for Human Error Rate Prediction) e a simulação de Monte Carlo as mais destacadas. Swain (1990) classificou os métodos de análise de confiabilidade humana como métodos de duas gerações. A primeira geração de métodos foi influenciada amplamente pelo enfoque de análise probabilística de segurança (PSA). Swain afirmou que a metodologia THERP tinha chegado a um nível que podia ser aplicada a problemas industriais reais, enquanto a simulação de Monte Carlo começava a ser mostrar como uma metodologia significativa de pesquisa. Todos estes métodos dependem de dados qualitativos (ações de erros e PSFs) e quantitativos (probabilidades de erros humanos - HEP) para a avaliação das ações humanas.

Dentre os métodos de primeira geração desenvolvidos, os que merecem destaque são: THERP (Technique for Human ErrorRate Prediction), ASEP (Accident Sequence Evaluation Program), HCR (Human Cognitive Reliability), PHRA (Probabilistic Human Reliability Analysis) e SLIM (Success Likelihood Index Method). Seus dados podem ser extraídos de quatro diferentes fontes, podem ser: estimados de especialistas, estudos de simulação (em HCR e PHRA), experimentos e experiências operacionais (em THERP e ASEP). Swain (1983) considerou que as principais características comuns aos métodos da primeira geração foram:

1. O enfoque da THERP usa a tecnologia convencional de confiabilidade, no qual o desempenho humano é comparado ao desempenho de um equipamento (tarefas humanas são substituídas por probabilidades nominais de erros).

2. A análise de confiabilidade humana é limitada somente às ações humanas que são incluídas na análise probabilística de segurança na árvore de eventos. Assim, a qualidade da análise depende da precisão e o cuidado do modelo de análise probabilística de segurança. 
3. A ação humana é representada de forma binária, ou seja, os únicos resultados possíveis são sucesso integral ou falha integral.

4. Os aspectos cognitivos internos não tiveram o tratamento adequado. Os erros cognitivos foram tidos como a causa de uma omissão (uma tarefa ou parte de uma tarefa que deveria ter sido executada, mas não foi), ou de uma comissão (uma tarefa ou parte de uma tarefa que é executada incorretamente). Contudo, o erro cognitivo não acontece nesse estágio, e sim durante os processos de diagnoses (tais como: busca, classificação, interpretação, ou tomada de decisões).

5. A confiabilidade humana é tida como a probabilidade de que a ação humana requerida seja realizada corretamente no momento requerido, ou seja, é a probabilidade de "não ocorrer erro humano". O erro humano é determinado pelos limites de tolerância estabelecidos pelo sistema sobre o qual se atua; por isso a definição de confiabilidade humana está associada à confiabilidade e disponibilidade dos sistemas.

Pela forma como a quantificação das probabilidades do desempenho incorreto das ações humanas é feita, criou-se a necessidade de se manter um banco dedados sobre as probabilidades de erros humanos (HEP) para diferentes tarefas. Como alguns desses dados podem ser obtidos de situações nas quais as ações humanas podem ser descritas relativamente fáceis num ambiente simples, sua aplicação para as situações nas quais as ações humanas devem ser realizadas num ambiente mais complicado, pode ser errônea ou sem efeito.

6. Tratamento indireto do contexto: as ações humanas que necessitam ser analisadas são identificadas dentro de uma árvore de eventos. A tarefa de interesse é decomposta em subtarefas com suas correspondentes "probabilidades nominais de erros humanos". A análise da tarefa é complementada com os fatores de incidência no comportamento (Performance Shaping Factors - PSFs). Um PSF é qualquer fator que influencia no comportamento humano e portanto na qualidade de sua 
resposta ou desempenho. Entretanto os mecanismos no qual os PSFs exercem uma influência sobre o desempenho humano não são descritos através do modelo do operário. A influência dos PSFs sobre o desempenho do operário é simplesmente levado em conta através da multiplicação de HEPs nominais

Rassmussen (1990) desenvolveu o esquema S-R-K. Em tal método são considerados três tipos de comportamento humano: comportamento baseado na destreza (relação automática "estímulo - resposta"; não existe um processo de interpretação ou diagnóstico, e depende do nível de treinamento e prática mas não da complexidade da tarefa); comportamento baseado em regras (utiliza parcialmente tanto interpretação quanto nível de práticas); e o comportamento baseado no conhecimento (depende totalmente dos conhecimentos do operário e de sua habilidade para utilizá-los). Este modelo é baseado na suposição de que os seres humanos geralmente realizam suas tarefas no nível mais baixo possível para minimizar o volume de elementos de tomada de decisões ou de processos cognitivos. As tarefas baseadas na destreza requerem pouco ou nenhum processo de tomada de decisões e, por isso, ao receber o estímulo a tarefa é diretamente executada. No caso das tarefas baseadas em regras, certo processo de tomada de decisões é demandado, fazendo com que ao receber o estímulo inicial, a informação recebida passe por um processo de assimilação, processamento e planejamento do que será feito - o operador seleciona/decide qual o procedimento adequado para a situação.

Segundo Fujita (1992), Hannaman et. al tentaram combinar o esquema S-R$\mathrm{K}$ com o conceito de correlação tempo-confiabilidade, e propuseram o método HCR (Human Cognitive Reliability). Este método considerava os três tipos de comportamento humano anteriores: destreza, regras e conhecimento; assim como três fatores de incidência no comportamento: experiência, stress e interação homem-máquina.

Nos anos 80, algumas propostas de incorporação de modelos estatísticos à análise de confiabilidade humana surgiram, influenciando na criação de técnicas estruturadas. Uma delas, tida como a mais comum, foi o SHARP (Systematic Human Action Reliability) proposto por Hannaman. Tal modelo adota os métodos 
HCR e THERP como padrões para avaliação das falhas cognitivas e falhas de procedimento respectivamente.

Whalley (1983) afirmou que o método PRA (Probabilistic Risk Assessment) foi considerado o mais importante para aumentar a segurança em engenharia. Este método reforçou o fato de que havia uma necessidade para o estudo contínuo da falha humana. Embrey (1990) explorou o uso de especialistas para constituir um modelo de confiabilidade humana e proporcionar as probabilidades de falha. Esse modelo considera a Probabilidade de Erro Humano (HEP) como uma função dos PSFs, e os efeitos totais de diferentes PSFs podem ser agregados através da decomposição funcional de atributos múltiplos (Multiple Attribute Utility Decomposition). Este modelo é conhecido como SLIMMAU (Success Likelihood Index - Multiple Attribute Utility Decomposition).

O desenvolvimento da tecnologia mudou a natureza do trabalho humano. Por isso, no desenvolvimento de projetos de sistemas, além dos aspectos ergonômicos convencionais, devem ser considerados também os aspectos ergonômicos cognitivos. Assim, as análises de confiabilidade humana da primeira geração foram substituídas pela segunda geração dentro de um contexto sensitivo - análise de confiabilidade cognitiva.

Segundo Hollnagel (1998), as falhas humanas estão presentes nos sistemas cognitivos: a base para o entendimento do desempenho humano é ter um conhecimento detalhado das ações humanas tanto no contexto objetivo, quanto na sua imagem subjetiva (existente na mente humana). Desta forma, se é capaz de definir, predizer e reconhecer o limiar desse sistema cognitivo num contexto dado, o qual pode levar a erros cognitivos.

Segundo Domech (2004), os métodos da segunda geração, tais como ATHEANA (A Technique for Human Error Analysis), HERMES (Human Error Risk Management for Engineering Systems), MERMOS (Méthode d'Evaluation de la Réalisation des Missions Opérateur pour la Sureté) e CREAM (Cognitive Reliability and Error Analysis Method), já consideravam os níveis de decisão, os processos de diagnose, as destrezas, os conhecimentos do operador e os fatores organizacionais. Domech considerou as seguintes características como as mais notáveis dentre as comuns dos métodos de segunda geração: 
1. O método ATHEANA começa com uma apresentação de eventos de falha humana (HFEs) que são identificados a partir de cenários de acidente ao se utilizar um modelo de Análises Probabilístico de Segurança (PSA).

2. Os HFEs são caracterizados através de ações inseguras (AIs), as quais constituem ações inapropriadas escolhidas pelo operador (ou não escolhidas quando necessárias) que resultam numa degradação da condição de segurança do sistema.

3. O seguinte passo é para caracterizar o contexto de indução ao erro (EFC), que é o efeito combinado dos fatores de incidência no comportamento (PSF's) com as condições do sistema que criam uma situação em que o erro humano é provável.

Hollnagel (1998) definiu as seguintes características do modelo ATHEANA:

1. É centrado na identificação do contexto de indução ao erro e dos erros humanos, em particular aos erros de comissão que podem ocorrer no contexto de indução ao erro após o acontecimento de um acidente (ao cometer um erro o pessoal pode originar uma situação anormal ou acidente).

2. Procedimentos muito detalhados para se conhecer em detalhe a razão pela qual as ações não seguras são associadas a eventos de falha humana. $\mathrm{O}$ método identifica detalhadamente os mecanismos de erros através de regras formais e informais (procedimento heurístico). É usado para fazer uma análise retrospectiva (causa - contexto - efeito; efeito - contexto - causa) de um número pequeno de eventos de falha humana.

3. É um tipo de PSA orientado, no qual os eventos de falha humana são tratados de uma forma binária de sucesso ou falha. 
4. É centrada fundamentalmente em análises de identificação de erros humanos pós-acidentes.

O CREAM é um método de análise tanto retrospectivo quanto prospectivo. A análise prospectiva ajuda a predizer como será o desempenho humano indo desde as causas até os efeitos. A análise retrospectiva faz uma análise dos eventos desde o efeito até as causas. Este método, quando usado para predizer o desempenho humano, apresenta as seguintes características (Domech, 2004):

1. A tarefa é selecionada a partir da Análise Probabilística de Segurança de conseqüências de um evento ou a partir de outra análise similar.

2. A tarefa é analisada através de um método de análise hierárquico de tarefas.

3. São avaliadas as condições de trabalho, também chamadas de condições de desempenho comum (CPCs - Common Performance Conditions) sob as quais é desempenhada a tarefa. Um total de nove CPCs é usado no CREAM: (a) adequação da organização, (b) condições de trabalho, (c) adequação da interação homem-máquina e do suporte operacional, (d) disponibilidade dos procedimentos, (e) número de objetivos simultâneos, (f) disponibilidade de tempo, (g) horário do dia, (h) adequação da preparação e do treinamento, e (i) qualidade da colaboração do grupo.

4. O Perfil de Demandas Cognitivas é construído para identificar as demandas específicas para o conhecimento em termos de um conjunto simplificado de funções cognitivas, ou seja, observação, interpretação, planejamento e execução. 
5. A probabilidade do uso do modo de controle é determinada para cada elemento da tarefa através de uma integração de efeitos dos CPCs específicos para a tarefa dada.

6. A probabilidade de falha da função cognitiva é identificada em termos das quatro funções cognitivas mencionadas em (4).

7. As probabilidades de falhas cognitivas para cada elemento da tarefa e para a tarefa como um todo podem ser estimadas através da probabilidade nominal de falha cognitiva (CFP) para cada probabilidade de falha das funções cognitivas e, em seguida avaliandose os efeitos dos CPCs sobre os valores CFPs nominais.

Segundo Kim (2001), as características fundamentais do CREAM são descritas como um método que:

1. Identifica as tarefas ou ações humanas que requerem ou dependem do conhecimento e da experiência humana, e que podem ser afetadas pelas variações na confiabilidade cognitiva.

2. Determina as condições (tarefas ou ações) sob as quais a confiabilidade cognitiva pode ser reduzida, e quando podem constituir uma fonte de risco (CPCs).

3. Avalia as conseqüências do desempenho humano sobre a segurança do sistema usado nas PSAs.

4. Desenvolve e especifica modificações que melhorem estas condições (tarefas ou ações), desde que sirvam para aumentar a confiabilidade cognitiva.

A metodologia tradicional utilizada no Departamento de Engenharia Elétrica da PUC-Rio em projetos e teses passadas é baseada em PSFs (Performance Shaping Factors) (Domech, 2004), (Domech, 2007), (Szwarcman, 2009), e 
(Szwarcman, 2010).Faz-se uso da aplicação de questionários para os colaboradores da empresa, possibilitando uma coleta de seu desempenho junto às suas tarefas; em paralelo outro questionário é apresentado a especialistas, que tem suas opiniões agregadas em um padrão de desempenho esperado para cada PSF. Embora números fuzzy sejam utilizados para agregar opinião destes especialistas,não existem sistemas de inferência. Ao final é montado um quadro comparativo, no qual o desempenho humano (discriminado por colaborador) pode ser avaliado ao se verificar quão distante do padrão (positiva ou negativamente) está cada PSF considerado. Porém, existem críticas ao uso de PSFs para avaliar a confiabilidade humana (Hollnagel, 2005): diz-se que a análise baseada em PSF's contém duas suposições errôneas do ponto de vista da ciência do comportamento. Uma é considerar que a probabilidade de falha de uma ação independe do contexto no qual ela está inserida; e a outra é considerar que o desempenho de um dado PSF não influencia nos demais. E Dessa maneira, percebeu-se a necessidade de caracterizar a confiabilidade humana de uma forma que o contexto tivesse maior influencia e que os PSF's fossem avaliados em conjunto.

\subsection{2.}

\section{Tipos de Erro}

A metodologia proposta considera que o processo a ser analisado seja estruturado conforme exibido na Figura 1:

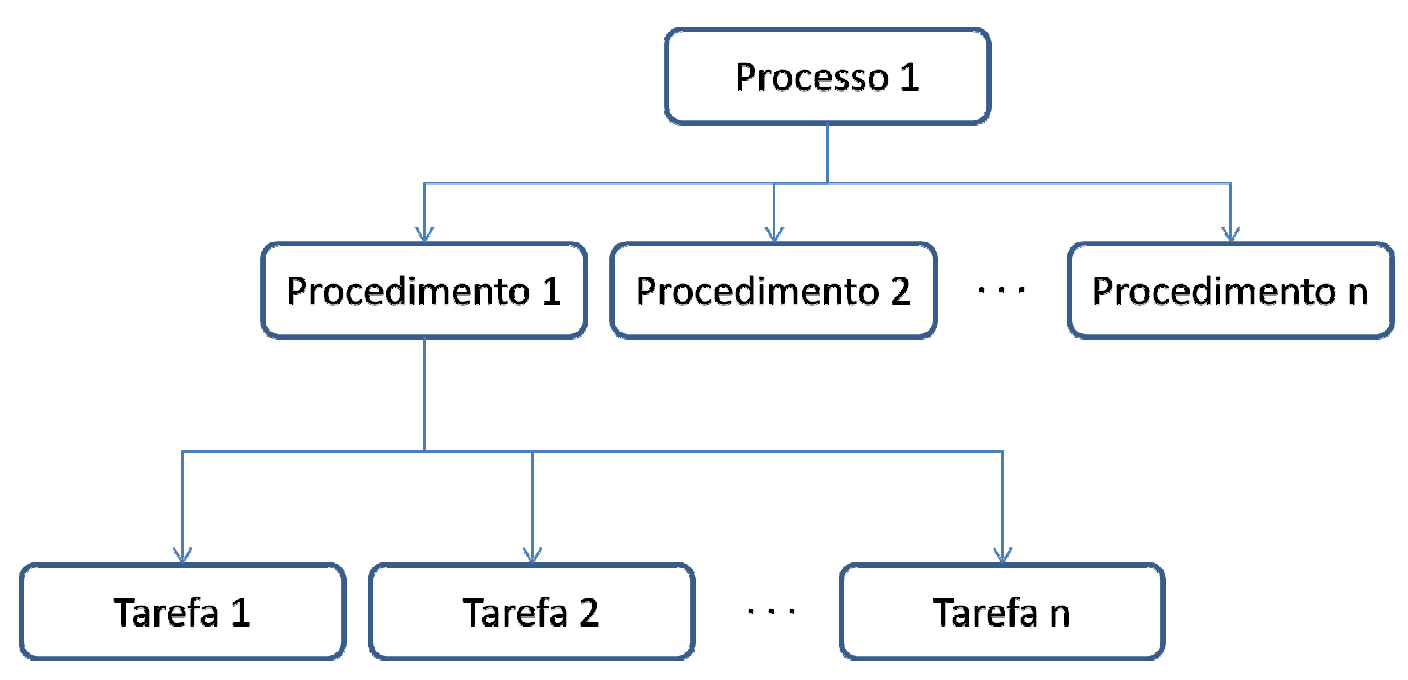

Figura 1: Estrutura de Processos 
Essa abordagem é a mesma utilizada pela maioria dos modelos de caracterização da confiabilidade humana existentes na literatura, e permite assumir que a confiabilidade de um processo é dada pela agregação das confiabilidades individuais de cada uma de suas tarefas.

Os erros humanos ocorrem em tarefas que devem ser executadas em determinada seqüência, que por sua vez formam um processo. Cada tarefa que venha a ser executada erroneamente, ou apenas parcialmente executada, ou não executada, afetará diferentemente o processo. Pode-se dizer que cada tarefa tem um nível de importância para que o processo possa ser realizado com sucesso. Dessa maneira, percebe-se que diferentes tarefas são influenciadas por diferentes PSF's. Além disso, diferentes PSF's resultam em diferentes tipos de erros, quando não atendidos satisfatoriamente.

Abaixo são mostradas as Tabelas 1, 2, 3, 4, 5 e 6, adaptadas da utilizada na metodologia PHEA - Análise Preditiva do Erro Humano (Embrey, 2010), que pode ser utilizada para auxiliar na organização dos tipos de erros humanos possíveis.

\begin{tabular}{|c|c|}
\hline \multicolumn{2}{|c|}{ Erros de Ação } \\
\hline A1 & Operação muito longa / curta \\
\hline A2 & Tempo de operação mal calculado \\
\hline A3 & Operação na direção errada \\
\hline A4 & Operação excessiva / atenuada \\
\hline A5 & Operação muito rápida / muito lenta \\
\hline A6 & Desalinhamento \\
\hline A7 & Operação correta em objeto errado \\
\hline A8 & Operação errada em objeto certo \\
\hline A9 & Operação omitida \\
\hline A10 & Operação incompleta \\
\hline A11 & Operação muito adiantada / atrasada \\
\hline A12 & Operação executada na ordem errada \\
\hline A13 & Posicionamento equivocado \\
\hline
\end{tabular}

Tabela 1: Erros de Ação 


\begin{tabular}{|c|c|}
\hline \multicolumn{2}{|c|}{ Erros de Verificação } \\
\hline V1 & Verificação omitida \\
\hline V2 & Verificação incompleta \\
\hline V3 & $\begin{array}{c}\text { Verificação correta no objeto } \\
\text { errado }\end{array}$ \\
\hline V4 & Verificação errada no objeto certo \\
\hline V5 & $\begin{array}{c}\text { Verificação muito adiantada / } \\
\text { atrasada }\end{array}$ \\
\hline
\end{tabular}

Tabela 2: Erros de Verificação

\begin{tabular}{|c|c|}
\hline \multicolumn{2}{|c|}{ Erros de Recuperação } \\
\hline R1 & Informação não obtida \\
\hline R2 & Informação errada obtida \\
\hline R3 & $\begin{array}{c}\text { Recuperação parcial da } \\
\text { informação }\end{array}$ \\
\hline R4 & $\begin{array}{c}\text { Informação interpretada } \\
\text { erroneamente }\end{array}$ \\
\hline
\end{tabular}

Tabela 3: Erros de Recuperação

\begin{tabular}{|c|c|}
\hline \multicolumn{2}{|c|}{ Erros de Comunicação } \\
\hline C1 & Informação não comunicada \\
\hline C2 & Informação errada comunicada \\
\hline C3 & $\begin{array}{c}\text { Comunicação parcial da } \\
\text { informação }\end{array}$ \\
\hline C4 & $\begin{array}{c}\text { Informação comunicada de } \\
\text { maneira não clara }\end{array}$ \\
\hline
\end{tabular}

Tabela 4: Erros de Comunicação

\begin{tabular}{|l|c|}
\hline \multicolumn{2}{|c|}{ Erros de Escolha } \\
\hline E1 & Escolha omitida \\
\hline E2 & Escolha errada \\
\hline
\end{tabular}

Tabela 5: Erros de Escolha

\begin{tabular}{|l|c|}
\hline \multicolumn{2}{|c|}{ Erros de Planejamento } \\
\hline P1 & $\begin{array}{c}\text { Planejamento incorreto devido a } \\
\text { análise prévia errada }\end{array}$ \\
\hline P2 & $\begin{array}{c}\text { Análise prévia correta, porém } \\
\text { planejamento mal formulado }\end{array}$ \\
\hline
\end{tabular}

Tabela 6: Erros de Planejamento 
Outra maneira de se classificar erros humanos em diferentes tipos, é sugerida por Hendrickson (2010). Esta abordagem é similar a anterior, porém alguns grupos são unificados, de maneira que todo e qualquer erro humano é classificado como um erro de Informação, de Decisão, ou de Ação. Os três diferentes tipos de erros humanos são associados com a etapa em que ocorreu, tais etapas estão presentes na execução de qualquer tarefa, e são elas:

- Etapa I (Informação) - externa ao operador, a informação é apresentada a ele. A demanda cognitiva associada à essa etapa é limitada à obtenção da informação (algum processamento dela pode ocorrer nessa etapa, porém consideravelmente limitado).

- Etapa D (Decisão) - interna ao operador. O operador utiliza a informação obtida/percebida/recebida na etapa anterior e, juntamente com suas memórias, conhecimento e experiência (além de vícios de execução), desenvolve um entendimento do que deve fazer e modela mentalmente a situação (ainda que involuntariamente). O operador entra num estágio mental de tomada de decisão, no qual planeja qual será a estratégia apropriada para lidar com a situação que lhe foi apresentada (isto é, situação que construiu mentalmente), escolhendo quais ações irá tomar. Essa etapa é dividida em duas sub-etapas: Diagnosticar: modelagem da situação; Decidir: escolher quais ações irá executar.

- Etapa A (Ação): execução da decisão tomada na etapa anterior.

Ainda, Hendrickson constatou que cada uma das etapas, que envolvem uma tarefa (recebimento de informação, tomada de decisão/planejamento, e execução/ação), contém por sua vez sub-etapas internas a elas. Então, a etapa de Informação contém três sub-etapas: informação, decisão e ação; por sua vez o mesmo é válido para as etapas de Decisão e de Ação.

A abordagem de Hendrickson é a mais adequada para o modelo proposto no Capítulo 3, pois propõe um entendimento prático mais simples do que a de Embrey, sem perder conteúdo. Contudo, a análise no nível das sub-etapas internas a cada uma das três principais é excessivo. Assim, a metodologia aqui 
desenvolvida irá se ater às etapas de Informação, Decisão, e Ação, conforme descrito no próximo capítulo. 


\section{3. \\ Metodologia}

A abordagem desenvolvida neste trabalho é explicada neste capítulo. Para facilitar o entendimento, faz-se o uso do diagrama de blocos exibido na Figura 2:

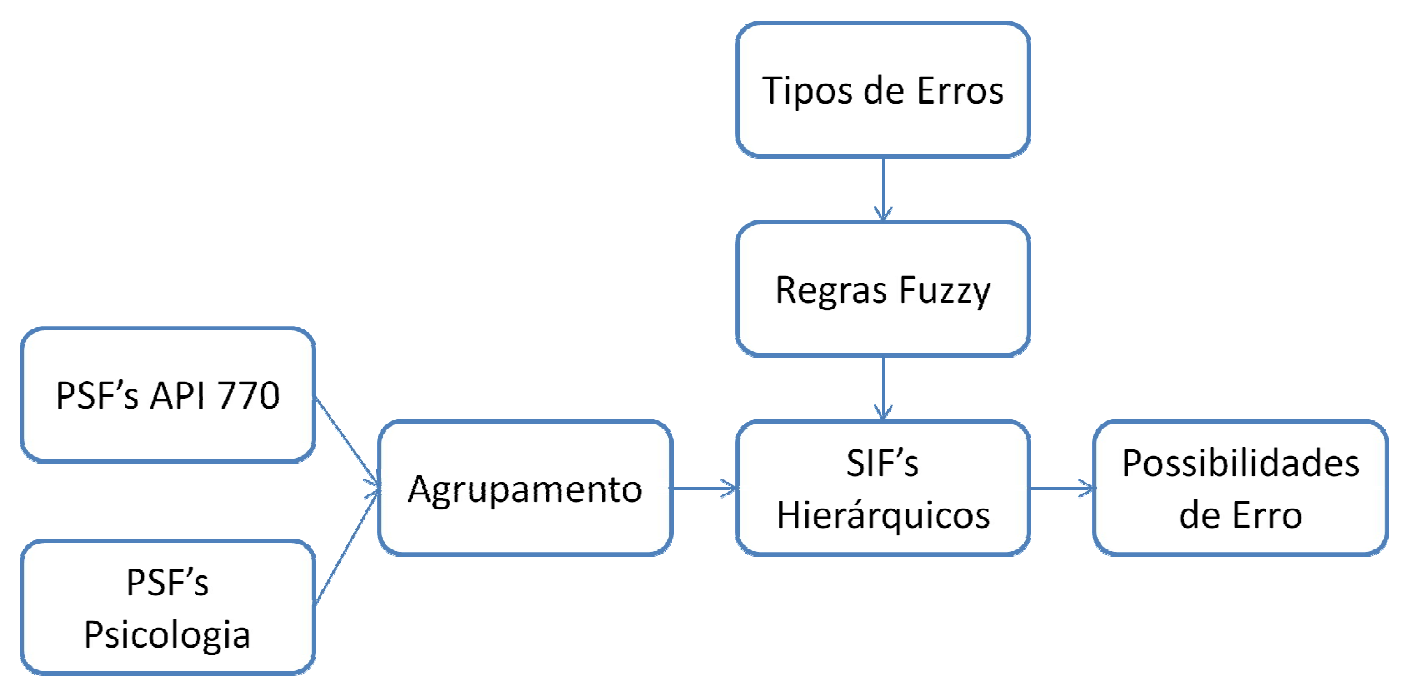

Figura 2: Diagrama de blocos do modelo proposto.

Primeiramente serão discutidos quais PSFs (Performance Shaping Factors) são mais pertinentes para a metodologia proposta. A seguir, serão agrupados e formarão Sistemas de Inferência Fuzzy Hierárquicos. Posteriormente, os tipos de erros referentes às etapas discutidas no Capítulo 2 serão associados às regras destes sistemas, para que então possam ser calculadas as possibilidades de erros de cada uma dessas três diferentes etapas relativas à confiabilidade humana no ambiente de trabalho.

\section{1.}

\section{Generalização da Metodologia}

A concepção dessa metodologia foi estabelecida com base em grupos de PSFs que se aplicam para diversos tipos de empresas e indústrias. Contudo, ela pode ser adaptada para incluir novos PSFs, ou até mesmo reorganizar a maneira 
como estes compõem os SIFs, visando a se ajustar a empresas com características particulares.

As etapas para a estruturação da metodologia são:

- Determinar quais PSFs serão utilizados (ou seja, quais são pertinentes ao contexto da empresa);

- Determinar quais PSFs serão agrupados para formar SIFs, levando em consideração seu grau de similaridade;

- Agrupar as saídas destes primeiros SIFs (possibilidades parciais de erro) para formar SIF's Hierárquicos até que um último SIF seja formado;

- Revisitar cada SIF de cada nível hierárquico, estabelecendo as regras fuzzy para cada tipo de erro humano que se deseja avaliar.

\section{2. \\ PSFs Avaliados}

A metodologia aqui proposta faz uso de 77 PSFs baseados na norma API 770 (Lorenzo 2001), bem como em normas de psicologia agrupadas por Wang (2008).

A norma API 770 foi publicada em 2001 e contém uma série de recomendações com o objetivo de diminuir erros humanos ao melhorar o desempenho humano em processos industriais (seu subtítulo é "A Manager's Guide to Reducing Human Errors - Improving Human Performance in the Process Industries"). Nela são apresentados os seguintes PSFs internos ao empregado: treinamento/habilidades; prática/experiência, conhecimento de padrões de desempenho, tensão mental ou física, inteligência, motivação, personalidade, estado emocional, gênero, condição física/saúde, influência de outros agentes externos (pessoas, família), identificação com o grupo e cultura. Porém, como citado, ela constitui um guia de boas práticas, diferenciando-se de uma metodologia aplicada. Como o trabalho aqui proposto visa à aplicação prática e à real diminuição de erros nas empresas, algumas adaptações são necessárias. As adaptações realizadas foram: 
- Estado emocional é uma variável extremamente volátil, que, embora indiscutivelmente influencie o comportamento humano, não pode ser medida diretamente e nem a todo instante. Uma maneira para se avaliá-la é representá-la por outras mais viáveis de se medir, como fatores cognitivos de personalidade - se um funcionário está com falta de atenção, fraca memória e tem alto teor de irritabilidade e agressividade, é lógico que o seu estado emocional não está bom. Estes fatores citados são mais viáveis de serem medidos.

- Gênero é outro fator citado na norma API 770 que não deve ser considerado ao se avaliar a possibilidade de erro humano, pois é controverso afirmar que em uma determinada tarefa homens tem mais chance de falhar do que mulheres, ou vice-versa. Gênero é uma variável de "alto nível"; se for desejável avaliá-la pode-se fazer uso de outras variáveis que a expliquem, isto é, se homens teoricamente são mais indicados para desempenhar alguma função envolvendo força física, deve-se simplesmente considerar os PSFs Exercício Físico, Fadiga, Constrição de Movimentos e Longa Duração do Stress Fisiológico. Se, estatisticamente, mulheres são mais indicadas para exercer alguma função que necessite de uma maior organização, devese analisar o comportamento dos PSFs Capacidade Analítica, Capacidade de Classificação, Ordem, e Desempenho. Essas considerações são de suma importância, uma vez que um empregado do sexo masculino pode cumprir determinada função com melhor desempenho que um funcionário do sexo feminino, mesmo que historicamente ela seja mais bem desempenhada por mulheres, ou vice-versa.

- O PSF Inteligência, para qualquer tarefa que não seja apenas mecânica/"braçal", é essencial, porém medir a inteligência de uma pessoa é tão polêmico quanto difícil. Testes de Q.I. medem raciocínio lógico, o que não é exatamente inteligência. Qualquer teste com um tema de estudo irá medir mais conhecimento e cultura do que de fato a inteligência, além de ser afetado diretamente pelo estado emocional do 
respondente. Ainda que fosse possível medir corretamente a inteligência de uma pessoa, atribuir a falha em um processo à deficiência de intelecto é politicamente incorreto e passível de ações judiciais. Para contornar esse problema, pode-se medir as capacidades intelectuais mais pertinentes ao trabalho de uma pessoa em uma empresa, tais como: Capacidade Analítica, Capacidade de Antecipação, Capacidade de Classificação, Capacidade de Tomada de Decisões, Inteligência numérica (capacidade de cálculos), Memória, Percepção de séries, e Predisposição para novos conhecimentos.

- O PSF personalidade foi desmembrado em diversos outros, e será detalhado a seguir.

A influência da personalidade de um funcionário na maneira como este irá desempenhar suas funções não pode ser ignorada. Se a personalidade é capaz de influenciar a forma como se realiza uma tarefa, necessariamente tem sua parcela de impacto na possibilidade de uma pessoa cometer diferentes tipos de erro. A atenção dada pela norma API 770 ao PSF personalidade é pouca, o que dificulta sua aplicação prática, pois não se trata de um fator que pode ser classificado como "bom" ou "ruim". Para se medir quão adequada a personalidade de cada pessoa é a uma determinada tarefa, decidiu-se torná-la um grupo de PSFs, de maneira que cada quesito da personalidade pudesse ser avaliado separadamente num primeiro estágio, para a seguir ser considerado em conjunto com os demais.

Outro aspecto importante que deve ser considerado é a existência dos fatores cognitivos. A forma de perceber o ambiente a sua volta, bem como assimilar os acontecimentos, está presente/ativa constantemente e ininterruptamente ao se realizar qualquer ação, seja no trabalho quanto na vida pessoal. Sendo assim, artigos de Psicologia foram consultados para se estabelecerem diretrizes para se avaliar a influência destes fatores no desempenho humano. A variedade de fatores cognitivos e de personalidade estudados na psicologia é consideravelmente ampla e o nível de detalhe pode ser tão profundo quanto se queira. Wang (2008) sugere uma lista extensa destes fatores relacionados ao estudo de erros humanos. Os fatores citados em seu trabalho incluem: segurança/medo, alegria/tristeza, prazer/raiva, amor/ódio, ambição, 
impulsividade, tentativa durante incerteza, obediência a regras, auto-expectativa, orgulho de seu trabalho, responsabilidade, disciplina, meticulosidade, cuidado, assertividade, ser enérgico, tolerante, sensibilidade, confiante, individualista, trabalho em equipe, produtividade, persistência, conhecimento, habilidade, experiência, instrutivo, aprendizagem, expressividade, transferência de conhecimento, reação a eventos, eficiência, atenção, abstração, busca, categorização, planejamento, capacidade de tomada de decisão, solução de problemas, análise, síntese, ser agradável, tolerante, prestativo, abrangência de contato, variedade de formas de contato, consultivo, responsável, respeitoso, confiável, simpático, modesto, fiel, flexível, independente, capacidade de colaboração, capacidade de comunicação, extrovertido, introvertido, cultura, liderança, orientação de grupo, capacidade de organização, consideração com os demais, compatibilidade, taxa de erros contingentes, taxa de erros repetidos, capacidade de corrigir erros, capacidade de apontar, concentração, precisão, percepção, consistência, sistematização, talento, capacidade de abstração, imaginação, capacidade de criar analogias, curiosidade, habilidade de modelar/design, habilidade manual, mente aberta, hobbies, ser quieto, ativo, literatura, e visão. Porém, medir todas essas variáveis para todos os empregados de uma empresa pode ser inviável do ponto de vista prático, devido ao dispêndio de tempo e custo. Assim, selecionaram-se alguns desses fatores para que a personalidade e a capacidade cognitiva de cada funcionário pudessem ser avaliadas de maneira pertinente ao objetivo que se deseja alcançar: identificar possíveis erros humanos utilizando Lógica Fuzzy.

Os fatores foram condensados em:

- Fatores Cognitivos

- Capacidade Analítica

- Capacidade de Antecipação

- Capacidade de Classificação

- Capacidade de Tomada de Decisões

- Continuidade de matrizes ou conjuntos

○ Estruturação do campo perceptivo (topologia)

- Identificação com grupos

- Inteligência numérica (capacidade de cálculos) 

○ Memória
○ Nível de Atenção
- Percepção de séries
○ Predisposição para novos conhecimentos

- Fatores de Personalidade
- Afago
○ Afiliação
○ Agressão
- Assistência
- Autonomia
- Deferência
○ Denegação
○ Desempenho
○ Dominância
○ Exibição
○ Intracepção
○ Mudança
- Ordem
- Persistência

Os fatores do Grupo de PSFs Fatores de Personalidade representam as seguintes características:

- Afago - desejar afago, ou seja, apoio, orientação ou necessitar constantemente de alguém que o entenda e o proteja, ou sofrer de ansiedade, insegurança e desespero

- Afiliação - demonstração de confiança, boa vontade e lealdade aos colegas de trabalho

- Agressão - elevado grau de irritação, com desejo de superar com vigor e violência a oposição

- Assistência - desejos e sentimentos de piedade, compaixão e ternura, pelos quais o sujeito deseja ser simpático 
- Autonomia - não gostar de executar as tarefas impostas pela autoridade e tender a desafiar as convenções

- Deferência - necessidade de admirar e reverenciar, ou seja, expressar o desejo de admirar e dar suporte a um superior, gostar de elogiar e honrar os superiores e obedecê-los

- Denegação - sentimento de resignação, admissão de inferioridade, erro e fracasso

- Desempenho - sentimento de ambição e empenho, desejo de realizar algo difícil como organizar objetos, pessoas, idéias, gostar de se sobressair, fazer coisas com rapidez, vencer obstáculos e manter altos padrões de desempenho

- Dominância - sentir auto-confiança e desejo de controlar os outros, influenciar ou dirigir o comportamento dos colegas através de sugestão, persuasão ou comando

- Exibição - ser vaidoso, gostar de dramatizar os fatos para impressionar e entreter

- Intracepção - tendência de se deixar determinar pelas condições concretas, observáveis e físicas, ser pessoal nos julgamentos, pouco prático, egocêntrico, individualista, intuitivo nas observações, dedutivo e parcial em suas opiniões

- Mudança - gostar de novidade, com pouca ligação aos lugares, pessoas ou objetos, gostar de coisas novas e diferentes

- Ordem - tendência de organização, equilíbrio e precisão

- Persistência - tendência a finalizar qualquer trabalho, ainda que difícil (pessoas que primam por ver o resultado final de um trabalho)

A norma API 770 também indica a importância de se avaliar o ambiente em que o empregado está inserido. O grupo de PSFs que trata destas características é o de PSFs Externos contemplando: Ações desenvolvidas por Supervisores, Colegas, Representantes de Sindicatos e Pessoal de Regulamentação; Capacidade Crítica da Tarefa; Complexidade da Tarefa (Carga de Informações); Comunicação; Cuidados e Advertências; Disponibilidade de Equipamentos Especiais; Estrutura de Equipe; Estrutura Organizacional; Fatores de Interface de 
Hardware; Feedback (Conhecimento de Resultados); Freqüência e Repetitividade da Tarefa; Horas de Trabalho / Intervalos de Trabalho; Instrumentos; Insumos; Métodos de Trabalho; Políticas da Planta; Procedimentos (Escritos ou Não Escritos); Qualidade do Ambiente; Quantidade de Pessoal; e Rodízio de Turnos.

Os PSFs estudados e seus grupos, são apresentados na Tabela 7.

\begin{tabular}{|c|c|}
\hline Grupo de PSF's & Nome do Fator \\
\hline Fatores Cognitivos & Capacidade Analítica \\
\hline Fatores Cognitivos & Capacidade de Antecipação \\
\hline Fatores Cognitivos & Capacidade de Classificação \\
\hline Fatores Cognitivos & Capacidade de Tomada de Decisões \\
\hline Fatores Cognitivos & Continuidade de matrizes ou conjuntos \\
\hline Fatores Cognitivos & Estruturação do campo perceptivo (topologia) \\
\hline Fatores Cognitivos & Identificação com grupos \\
\hline Fatores Cognitivos & Inteligência numérica (capacidade de cálculos) \\
\hline Fatores Cognitivos & Memória \\
\hline Fatores Cognitivos & Nível de Atenção \\
\hline Fatores Cognitivos & Percepção de séries \\
\hline Fatores Cognitivos & Predisposição para novos conhecimentos \\
\hline Fatores de Personalidade & Afago \\
\hline Fatores de Personalidade & Afiliação \\
\hline Fatores de Personalidade & Agressão \\
\hline Fatores de Personalidade & Assistência \\
\hline Fatores de Personalidade & Autonomia \\
\hline Fatores de Personalidade & Deferência \\
\hline Fatores de Personalidade & Denegação \\
\hline Fatores de Personalidade & Desempenho \\
\hline Fatores de Personalidade & Dominância \\
\hline Fatores de Personalidade & Exibição \\
\hline Fatores de Personalidade & Intracepção \\
\hline Fatores de Personalidade & Mudança \\
\hline Fatores de Personalidade & Ordem \\
\hline Fatores de Personalidade & Persistência \\
\hline Fatores de Stress Fisiológicos & Constrição de Movimentos \\
\hline
\end{tabular}




\begin{tabular}{|c|c|}
\hline Fatores de Stress Fisiológicos & Dor ou Desconforto \\
\hline Fatores de Stress Fisiológicos & Exercício Físico \\
\hline Fatores de Stress Fisiológicos & Fadiga \\
\hline Fatores de Stress Fisiológicos & Fome ou Sede \\
\hline Fatores de Stress Fisiológicos & Interrupção do Ritmo Circadiano \\
\hline Fatores de Stress Fisiológicos & Longa Duração do Stress \\
\hline Fatores de Stress Fisiológicos & Repetição de M ovimentos \\
\hline Fatores de Stress Fisiológicos & Trabalho em Alturas \\
\hline Fatores de Stress Psicológicos & Alta Velocidade na Execução da Tarefa \\
\hline Fatores de Stress Psicológicos & Ameaças (de Falha, de Perda do Emprego, etc.) \\
\hline Fatores de Stress Psicológicos & Carga Pesada de Informações \\
\hline Fatores de Stress Psicológicos & $\begin{array}{c}\text { Distrações (devido a Ruído, Clarão, M ovimentos, } \\
\text { etc.) }\end{array}$ \\
\hline Fatores de Stress Psicológicos & $\begin{array}{l}\text { Falta de Recompensas, Reconhecimento e } \\
\text { Benefícios }\end{array}$ \\
\hline Fatores de Stress Psicológicos & Início Inesperado do Stress \\
\hline Fatores de Stress Psicológicos & $\begin{array}{c}\text { M otivos Conflitantes sobre o Desempenho no } \\
\text { Trabalho }\end{array}$ \\
\hline Fatores de Stress Psicológicos & Perda de Sensibilidade \\
\hline Fatores de Stress Psicológicos & Períodos de Vigilância Longos, sem Acontecimentos \\
\hline Fatores de Stress Psicológicos & Reforço Negativo \\
\hline Fatores de Stress Psicológicos & Sugestões Inconsistentes \\
\hline Fatores de Stress Psicológicos & Trabalho M onótono, Degradante ou Sem Sentido \\
\hline Fatores Externos & $\begin{array}{c}\text { Ações desenvolvidas por Supervisores, Colegas, } \\
\text { Representantes de Sindicatos, e Pessoal de } \\
\text { Regulamentação }\end{array}$ \\
\hline Fatores Externos & Capacidade Crítica da Tarefa \\
\hline Fatores Externos & Complexidade da Tarefa (Carga de Informações) \\
\hline Fatores Externos & Comunicação \\
\hline Fatores Externos & Cuidados e Advertências \\
\hline Fatores Externos & Disponibilidade de Equipamentos Especiais \\
\hline Fatores Externos & Estrutura de Equipe \\
\hline Fatores Externos & Estrutura Organizacional \\
\hline Fatores Externos & Fatores de Interface de Hardware \\
\hline
\end{tabular}




\begin{tabular}{|c|c|}
\hline Fatores Externos & Feedback (Conhecimento de Resultados) \\
\hline Fatores Externos & Freqüência e Repetitividade da Tarefa \\
\hline Fatores Externos & Horas de Trabalho / Intervalos de Trabalho \\
\hline Fatores Externos & Instrumentos \\
\hline Fatores Externos & Insumos \\
\hline Fatores Externos & M étodos de Trabalho \\
\hline Fatores Externos & Políticas da Planta \\
\hline Fatores Externos & Procedimentos (Escritos ou Não Escritos) \\
\hline Fatores Externos & Qualidade do Ambiente \\
\hline Fatores Externos & Quantidade de Pessoal \\
\hline Fatores Externos & Rodízio de Turnos \\
\hline Fatores Internos & Condição Física/Saúde \\
\hline Fatores Internos & Conhecimento de Padrões de Desempenho \\
\hline Fatores Internos & Experiência \\
\hline Fatores Internos & $\begin{array}{l}\text { Influência de outros agentes externos (pessoas, } \\
\qquad \text { família) }\end{array}$ \\
\hline Fatores Internos & Motivação \\
\hline Fatores Internos & Nível de cultura de segurança \\
\hline Fatores Internos & Nível de cultura organizacional \\
\hline Fatores Internos & Nível de práticas \\
\hline Fatores Internos & Qualidade do Treinamento \\
\hline Fatores Internos & Tensão Mental ou Física \\
\hline
\end{tabular}

Tabela 7: Grupos de PSF's

\section{3.}

\section{Agrupamento e Estruturação dos SIFs Hierárquicos}

Um PSF mal desempenhado pode influenciar em todos os tipos de erros ou apenas em um deles. Por exemplo, o PSF Comunicação é evidentemente crítico para a etapa de Informação de inúmeras tarefas, porém, em uma análise preliminar, não seria tão importante para as demais etapas. Contudo, muitas tarefas podem ser executadas em grupo, fazendo com que a Comunicação seja essencial no momento da tomada de Decisão; assim como algumas tarefas são 
especialmente baseadas na transferência de informação e, com isto, a Ação também é influenciada diretamente por este PSF.

A metodologia aqui proposta faz uso de Lógica Fuzzy para calcular a possibilidade de falha de uma tarefa dado o desempenho de cada PSF. A capacidade de se lidar com variáveis e regras lingüísticas permite criar um modelo adaptável para cada etapa de avaliação dos PSFs. Uma grande crítica da qual a caracterização da confiabilidade humana por PSFs foi alvo (Hollnagel, 2005) é que avaliação de um PSF é feita independentemente do desempenho dos demais. $\mathrm{Na}$ prática, é fácil perceber que um fator de personalidade evidentemente influencia a maneira como um empregado irá utilizar sua experiência numa situação de emergência, assim como um fator cognitivo influencia a sua capacidade analítica no momento da tomada de decisão. A Lógica Fuzzy fornece o ferramental necessário para avaliar os PSFs em conjunto, agrupando-os em Sistemas de Inferência Fuzzy hierárquicos a cada etapa, mantendo a análise em grupo coerente sem deixar que se perca a noção do que está sendo considerado.

O modelo como um todo pode ser visto como um grande SIF, que recebe 77 variáveis lingüísticas de entrada e fornece a possibilidade de um erro ocorrer em uma determinada tarefa. Por ser inviável criar regras que analisem simultaneamente 77 variáveis, optou-se fazer uso de SIFs hierárquicos:

- PSFs similares ou com influência maior e mais direta sobre outro são agrupados em duplas ou trios e formam um SIF;

- a saída deste SIF será a possibilidade de erro parcial, causada pelo desempenho destes PSFs (como exemplificado na Figura 3);

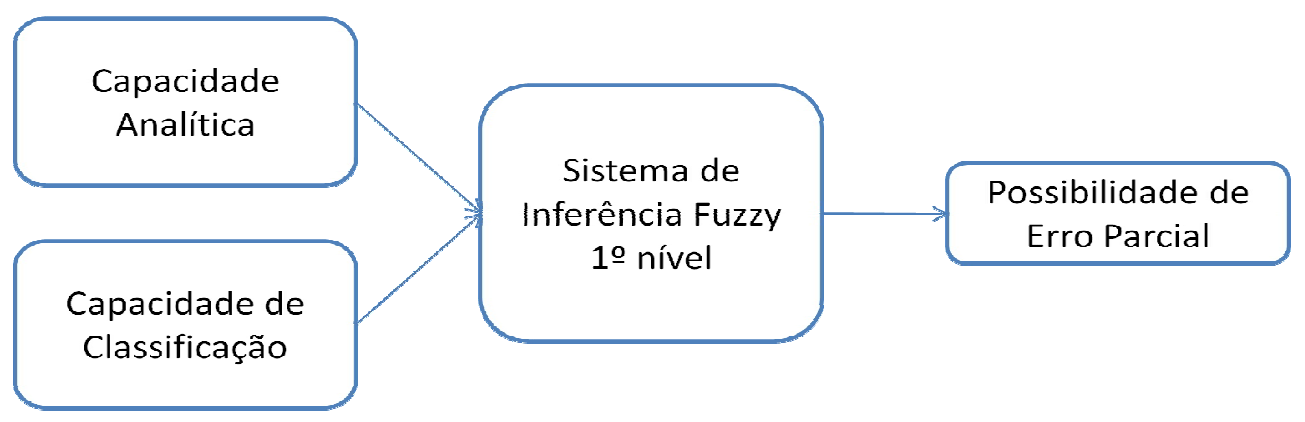

Figura 3: Exemplo de SIF hierárquico do primeiro nível. 
- esta saída será representativa dos PSF's que a gerou e se juntará com saídas de outros SIF's, também agrupadas em duplas ou trios, como variáveis de entrada do SIF seguinte (como exemplificado na Figura 4);

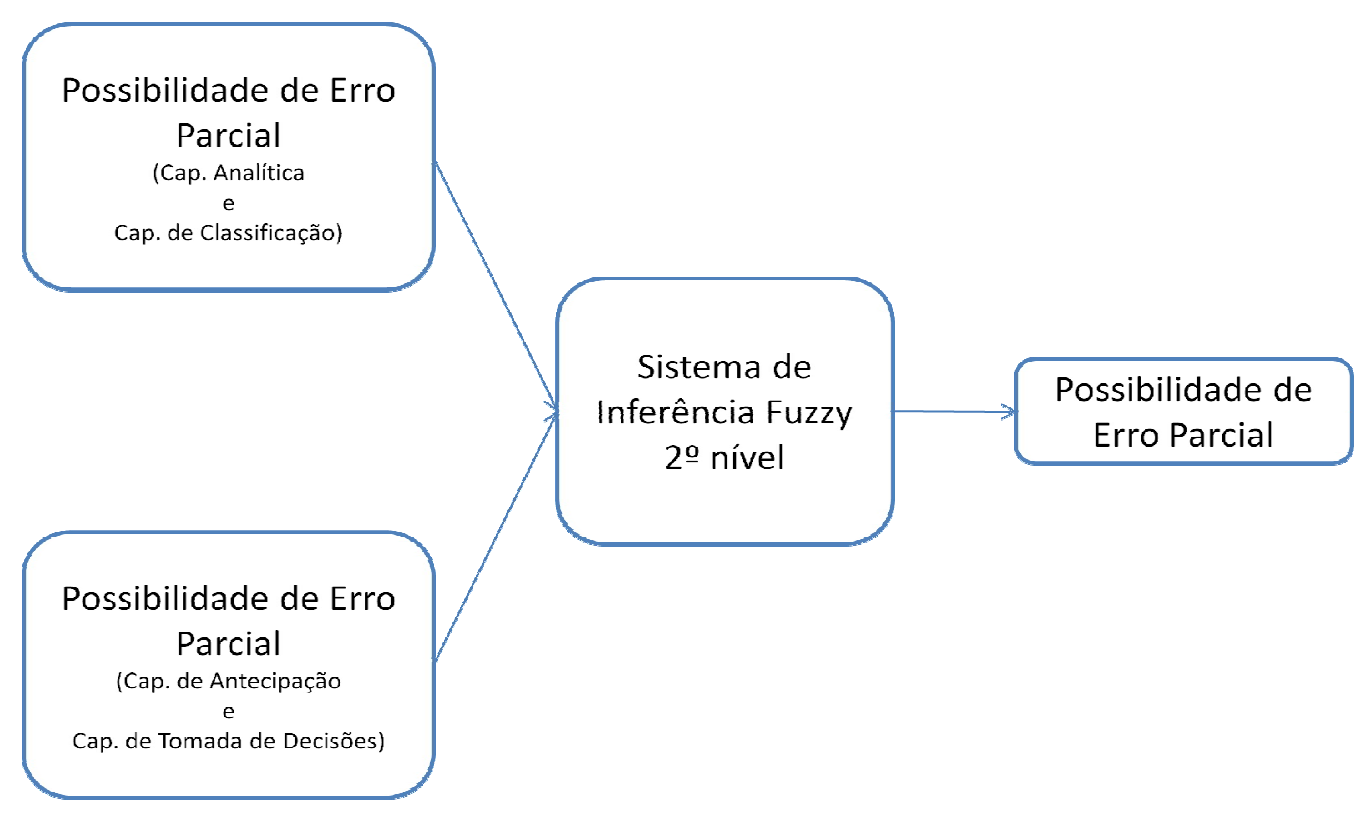

Figura 4: Exemplo de SIF hierárquico do segundo nível

- este novo SIF será responsável por agrupar as possibilidades de erro parciais e determinar qual a possibilidade de erro definida pelo conjunto de PSF's avaliados até o momento;

- o procedimento continua, até que todos os PSF's tenham sido avaliados, enquanto a influência do desempenho de cada um deles é considerada no desempenho dos demais, para se calcular finalmente a possibilidade de erro total da tarefa em questão.

Como o objetivo é não só calcular a possibilidade de erro, mas também especificar qual o seu tipo, e um SIF é tão eficiente quão bem estipuladas forem suas regras internas, faz-se necessário determinar regras diferentes para cada tipo de erro estudado. As variáveis de entrada (PSFs) são as mesmas para qualquer variável de saída (tipos de erro), diferindo apenas na maneira como influenciam nas demais e no nível de importância que assumem. Para ser possível contemplar todas as características citadas, é preciso criar um SIF para cada tipo de erro, com 
a mesma estrutura (variáveis de entrada e SIFs internos) e variando as regras, para uma melhor adequação ao tipo de erro que se deseja calcular.

Como citado anteriormente, os PSFs devem ser avaliados conjuntamente. Para tal, foram agrupados em pequenos conjuntos (com dois ou três elementos), baseando-se no grau de similaridade que apresentavam entre si e na capacidade de influenciar diretamente os demais. A Tabela 8 mostra o primeiro nível de agrupamento, isto é, os primeiros pares e trios formados por PSFs. Os agrupamentos seguintes são realizados unindo-se grupos dois a dois ou três a três. A cor e o número na coluna "Sub-grupo" indica como os PSFs foram agrupados. As linhas com letras no lugar de números indica que o PSF ainda não foi agrupado nesta etapa, por não ser tão semelhante ou influente em outro PSF, fazendo com que venha a ser melhor avaliado quando associado futuramente a um conjunto maior.

\begin{tabular}{|c|c|c|}
\hline Sub-grupo & Grupo de PSF & Nome do PSF \\
\hline 1 & Fatores Cognitivos & Capacidade Analítica \\
\hline 2 & Fatores Cognitivos & Capacidade de Antecipação \\
\hline 1 & Fatores Cognitivos & Capacidade de Classificação \\
\hline 2 & Fatores Cognitivos & Capacidade de Tomada de Decisões \\
\hline 3 & Fatores Cognitivos & Continuidade de matrizes ou conjuntos \\
\hline 3 & Fatores Cognitivos & $\begin{array}{l}\text { Estruturação do campo perceptivo } \\
\text { (topologia) }\end{array}$ \\
\hline A & Fatores Cognitivos & Identificação com grupos \\
\hline 4 & Fatores Cognitivos & $\begin{array}{l}\text { Inteligência numérica (capacidade de } \\
\text { cálculos) }\end{array}$ \\
\hline 5 & Fatores Cognitivos & Memória \\
\hline B & Fatores Cognitivos & Nível de Atenção \\
\hline 4 & Fatores Cognitivos & Percepção de séries \\
\hline 5 & Fatores Cognitivos & Predisposição para novos conhecimentos \\
\hline 6 & $\begin{array}{c}\text { Fatores de } \\
\text { Personalidade }\end{array}$ & Afago \\
\hline 6 & $\begin{array}{c}\text { Fatores de } \\
\text { Personalidade }\end{array}$ & Afiliação \\
\hline 7 & Fatores de & Agressão \\
\hline
\end{tabular}




\begin{tabular}{|c|c|c|}
\hline & Personalidade & \\
\hline 8 & $\begin{array}{c}\text { Fatores de } \\
\text { Personalidade }\end{array}$ & Assistência \\
\hline 7 & $\begin{array}{c}\text { Fatores de } \\
\text { Personalidade }\end{array}$ & Autonomia \\
\hline 8 & $\begin{array}{c}\text { Fatores de } \\
\text { Personalidade }\end{array}$ & Deferência \\
\hline C & $\begin{array}{c}\text { Fatores de } \\
\text { Personalidade }\end{array}$ & Denegação \\
\hline 9 & $\begin{array}{c}\text { Fatores de } \\
\text { Personalidade }\end{array}$ & Desempenho \\
\hline 9 & $\begin{array}{c}\text { Fatores de } \\
\text { Personalidade }\end{array}$ & Dominância \\
\hline 10 & $\begin{array}{c}\text { Fatores de } \\
\text { Personalidade }\end{array}$ & Exibição \\
\hline 10 & $\begin{array}{c}\text { Fatores de } \\
\text { Personalidade }\end{array}$ & Intracepção \\
\hline D & $\begin{array}{c}\text { Fatores de } \\
\text { Personalidade }\end{array}$ & Mudança \\
\hline 11 & $\begin{array}{c}\text { Fatores de } \\
\text { Personalidade }\end{array}$ & Ordem \\
\hline 11 & $\begin{array}{c}\text { Fatores de } \\
\text { Personalidade }\end{array}$ & Persistência \\
\hline 12 & $\begin{array}{c}\text { Fatores de Stress } \\
\text { Fisiológicos }\end{array}$ & Constrição de M ovimentos \\
\hline 12 & $\begin{array}{c}\text { Fatores de Stress } \\
\text { Fisiológicos }\end{array}$ & Dor ou Desconforto \\
\hline 13 & $\begin{array}{l}\text { Fatores de Stress } \\
\text { Fisiológicos }\end{array}$ & Exercício Físico \\
\hline 13 & $\begin{array}{c}\text { Fatores de Stress } \\
\text { Fisiológicos }\end{array}$ & Fadiga \\
\hline 14 & $\begin{array}{c}\text { Fatores de Stress } \\
\text { Fisiológicos }\end{array}$ & Fome ou Sede \\
\hline
\end{tabular}




\begin{tabular}{|c|c|c|}
\hline 14 & $\begin{array}{l}\text { Fatores de Stress } \\
\text { Fisiológicos }\end{array}$ & Interrupção do Ritmo Circadiano \\
\hline 15 & $\begin{array}{l}\text { Fatores de Stress } \\
\text { Fisiológicos }\end{array}$ & Longa Duração do Stress \\
\hline 15 & $\begin{array}{l}\text { Fatores de Stress } \\
\text { Fisiológicos }\end{array}$ & Repetição de M ovimentos \\
\hline$E$ & $\begin{array}{l}\text { Fatores de Stress } \\
\text { Fisiológicos }\end{array}$ & Trabalho em Alturas \\
\hline $\mathrm{F}$ & $\begin{array}{l}\text { Fatores de Stress } \\
\text { Psicológicos }\end{array}$ & Alta Velocidade na Execução da Tarefa \\
\hline 16 & $\begin{array}{c}\text { Fatores de Stress } \\
\text { Psicológicos }\end{array}$ & $\begin{array}{c}\text { Ameaças (de Falha, de Perda do Emprego, } \\
\text { etc.) }\end{array}$ \\
\hline 17 & $\begin{array}{c}\text { Fatores de Stress } \\
\text { Psicológicos }\end{array}$ & Carga Pesada de Informações \\
\hline 18 & $\begin{array}{l}\text { Fatores de Stress } \\
\text { Psicológicos }\end{array}$ & $\begin{array}{c}\text { Distrações (devido a Ruído, Clarão, } \\
\text { M ovimentos, etc.) }\end{array}$ \\
\hline 16 & $\begin{array}{c}\text { Fatores de Stress } \\
\text { Psicológicos }\end{array}$ & $\begin{array}{c}\text { Falta de Recompensas, Reconhecimento e } \\
\text { Benefícios }\end{array}$ \\
\hline 17 & $\begin{array}{c}\text { Fatores de Stress } \\
\text { Psicológicos }\end{array}$ & Início Inesperado do Stress \\
\hline 16 & $\begin{array}{l}\text { Fatores de Stress } \\
\text { Psicológicos }\end{array}$ & $\begin{array}{c}\text { Motivos Conflitantes sobre } 0 \\
\text { Desempenho no Trabalho }\end{array}$ \\
\hline 18 & $\begin{array}{l}\text { Fatores de Stress } \\
\text { Psicológicos }\end{array}$ & Perda de Sensibilidade \\
\hline 19 & $\begin{array}{c}\text { Fatores de Stress } \\
\text { Psicológicos }\end{array}$ & $\begin{array}{c}\text { Períodos de Vigilância Longos, sem } \\
\text { Acontecimentos }\end{array}$ \\
\hline 20 & $\begin{array}{l}\text { Fatores de Stress } \\
\text { Psicológicos }\end{array}$ & Reforço Negativo \\
\hline 20 & $\begin{array}{c}\text { Fatores de Stress } \\
\text { Psicológicos }\end{array}$ & Sugestões Inconsistentes \\
\hline 19 & $\begin{array}{c}\text { Fatores de Stress } \\
\text { Psicológicos }\end{array}$ & $\begin{array}{l}\text { Trabalho M onótono, Degradante ou Sem } \\
\text { Sentido }\end{array}$ \\
\hline 21 & Fatores Externos & $\begin{array}{l}\text { Ações desenvolvidas por Supervisores, } \\
\text { Colegas, Representantes de Sindicatos, e }\end{array}$ \\
\hline
\end{tabular}




\begin{tabular}{|c|c|c|}
\hline & & Pessoal de Regulamentação \\
\hline 22 & Fatores Externos & Capacidade Crítica da Tarefa \\
\hline 22 & Fatores Externos & $\begin{array}{l}\text { Complexidade da Tarefa (Carga de } \\
\text { Informações) }\end{array}$ \\
\hline 21 & Fatores Externos & Comunicação \\
\hline 23 & Fatores Externos & Cuidados e Advertências \\
\hline 24 & Fatores Externos & $\begin{array}{c}\text { Disponibilidade de Equipamentos } \\
\text { Especiais }\end{array}$ \\
\hline 25 & Fatores Externos & Estrutura de Equipe \\
\hline 25 & Fatores Externos & Estrutura Organizacional \\
\hline 23 & Fatores Externos & Fatores de Interface de Hardware \\
\hline 28 & Fatores Externos & Feedback (Conhecimento de Resultados) \\
\hline 26 & Fatores Externos & Freqüência e Repetitividade da Tarefa \\
\hline 26 & Fatores Externos & $\begin{array}{c}\text { Horas de Trabalho / Intervalos de } \\
\text { Trabalho }\end{array}$ \\
\hline 24 & Fatores Externos & Instrumentos \\
\hline 24 & Fatores Externos & Insumos \\
\hline 27 & Fatores Externos & M étodos de Trabalho \\
\hline 27 & Fatores Externos & Políticas da Planta \\
\hline 28 & Fatores Externos & Procedimentos (Escritos ou Não Escritos) \\
\hline G & Fatores Externos & Qualidade do Ambiente \\
\hline 29 & Fatores Externos & Quantidade de Pessoal \\
\hline 29 & Fatores Externos & Rodízio de Turnos \\
\hline 30 & Fatores Internos & Condição Física/Saúde \\
\hline 31 & Fatores Internos & $\begin{array}{c}\text { Conhecimento de Padrões de } \\
\text { Desempenho }\end{array}$ \\
\hline 31 & Fatores Internos & Experiência \\
\hline 30 & Fatores Internos & $\begin{array}{l}\text { Influência de outros agentes externos } \\
\text { (pessoas, família) }\end{array}$ \\
\hline 32 & Fatores Internos & M otivação \\
\hline 33 & Fatores Internos & Nível de cultura de segurança \\
\hline 33 & Fatores Internos & Nível de cultura organizacional \\
\hline
\end{tabular}




\begin{tabular}{|c|c|c|}
\hline 34 & Fatores Internos & Nível de práticas \\
\hline 34 & Fatores Internos & Qualidade do Treinamento \\
\hline 32 & Fatores Internos & Tensão M ental ou Física \\
\hline
\end{tabular}

Tabela 8: Agrupamento dos PSF's em SIF's de $1^{\circ}$ nível

Cada conjunto da Tabela 8 é um SIF do $1^{\circ}$ nível, que define regras de inferência fuzzy para cada combinação de comportamento/desempenho das suas variáveis de entrada, e a seguir calcula qual a possibilidade de falha parcial delas conjuntamente. A visualização do agrupamento dos SIFs, a partir do $2^{\circ}$ nível até o nível final, no formato de tabela dificulta a compreensão do modelo como um todo. Assim, a exibição do modelo é realizada por diagrama de blocos, conforme mostrado nas Figuras 5, 6, 7, 8 e 9. 


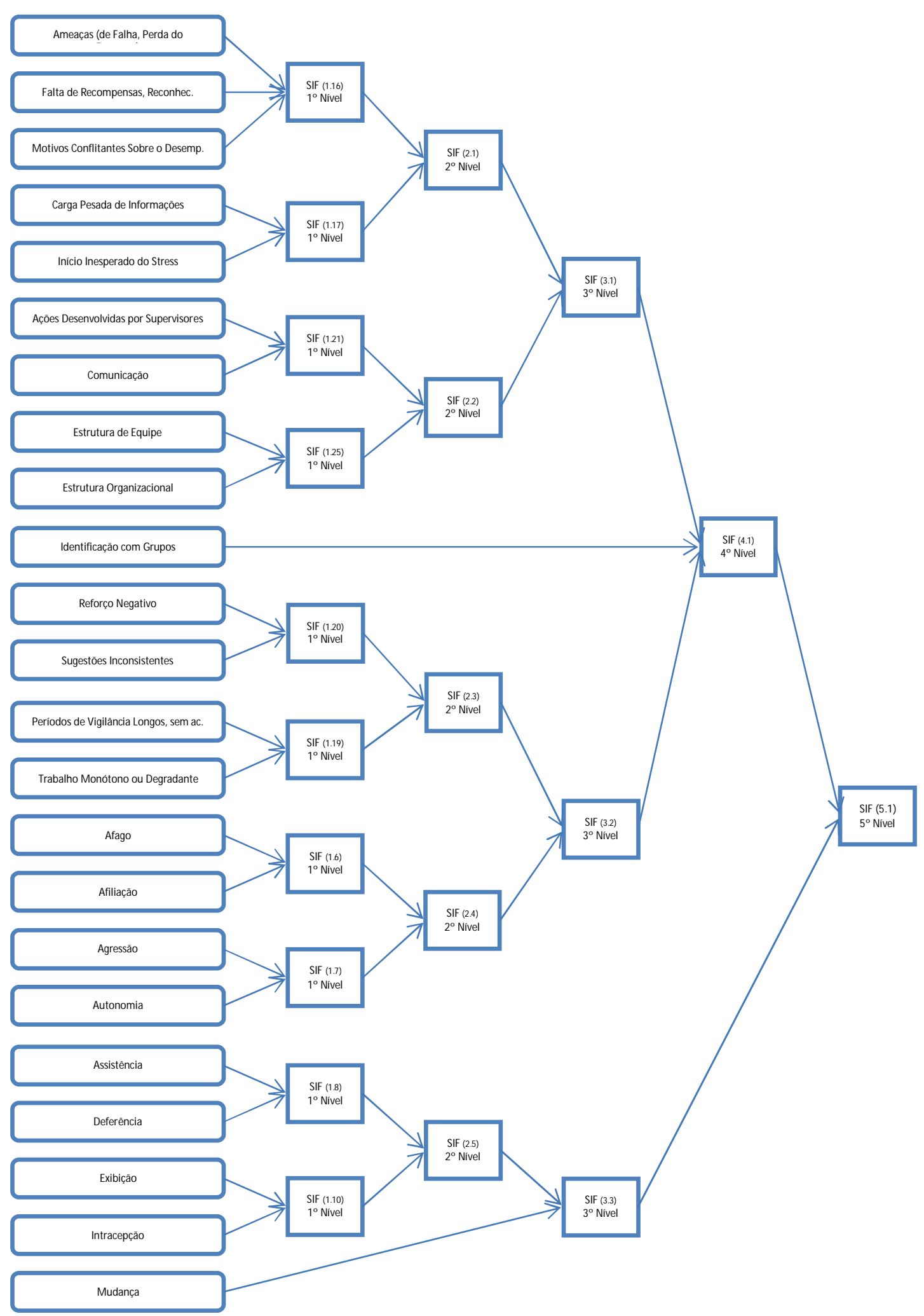

Figura 5: Agrupamento de SIFs hierárquicos do primeiro ao quinto nível (1 de 3)

Os SIFs hierárquicos mostrados na Figura 5 formam o SIF 5.1, que será agrupado com outro SIF posteriormente. 


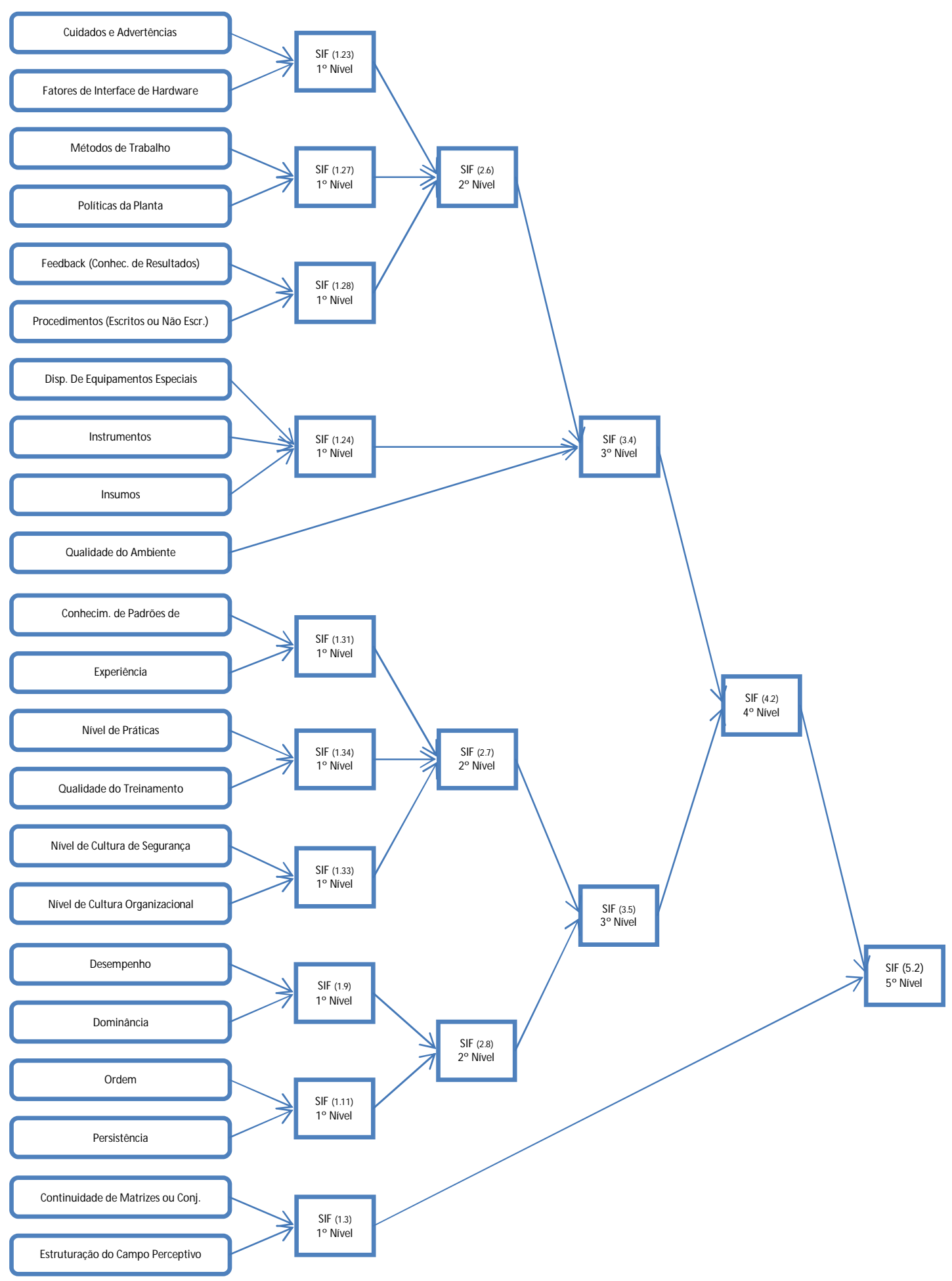

Figura 6: Agrupamento de SIFs hierárquicos do primeiro ao quinto nível (2 de 3)

Analogamente à Figura 5, os SIFs hierárquicos mostrados na Figura 6 formam o SIF 5.2, cuja saída servirá de variável de entrada para um SIF de nível superior (SIF 6.1). 


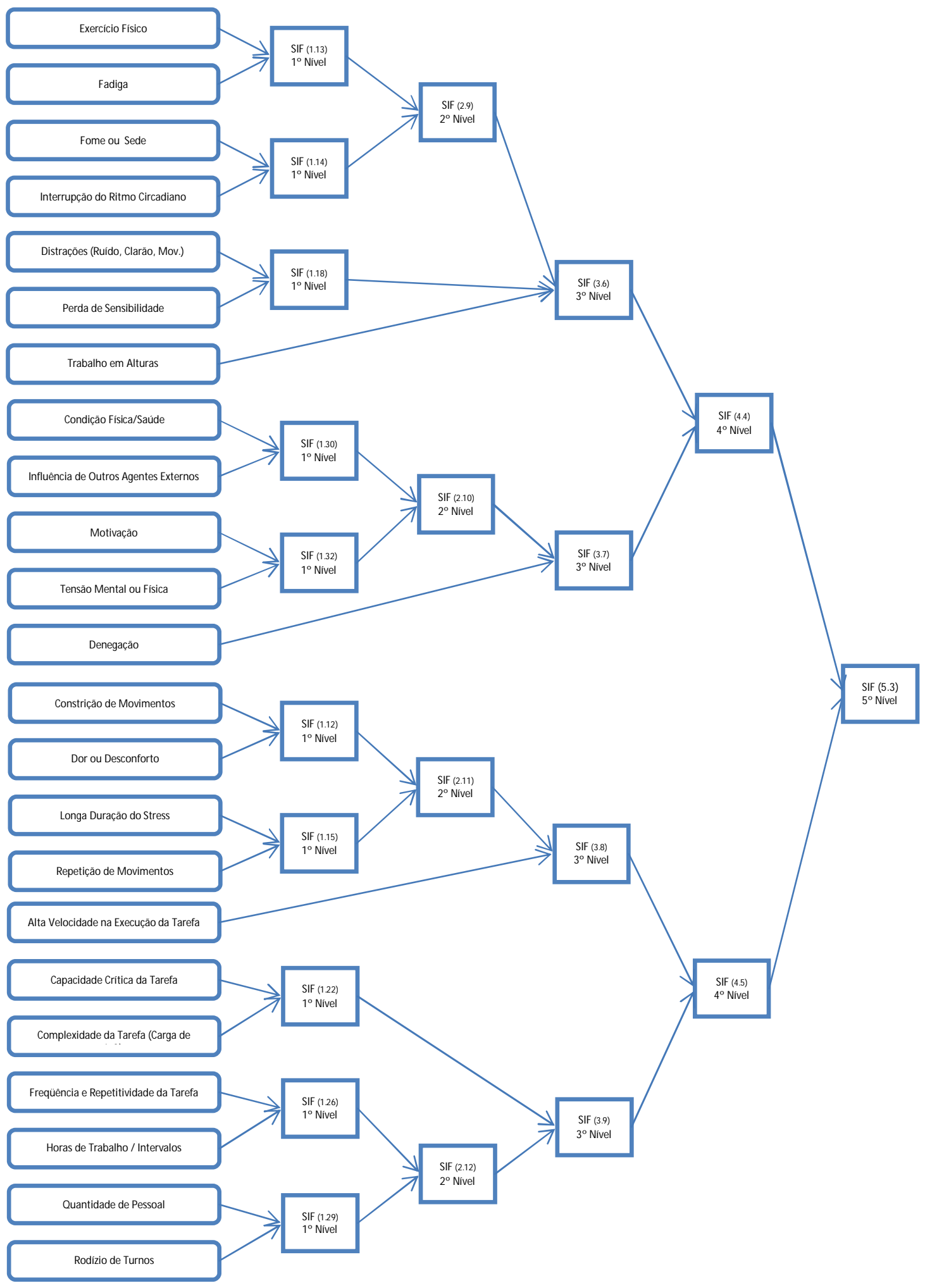

Figura 7: Agrupamento de SIFs hierárquicos do primeiro ao quinto nível (3 de 3)

Os SIFs hierárquicos mostrados na Figura 7 formam o SIF 5.3, cuja saída também servirá de variável de entrada para um SIF de nível superior (SIF 8.1). 


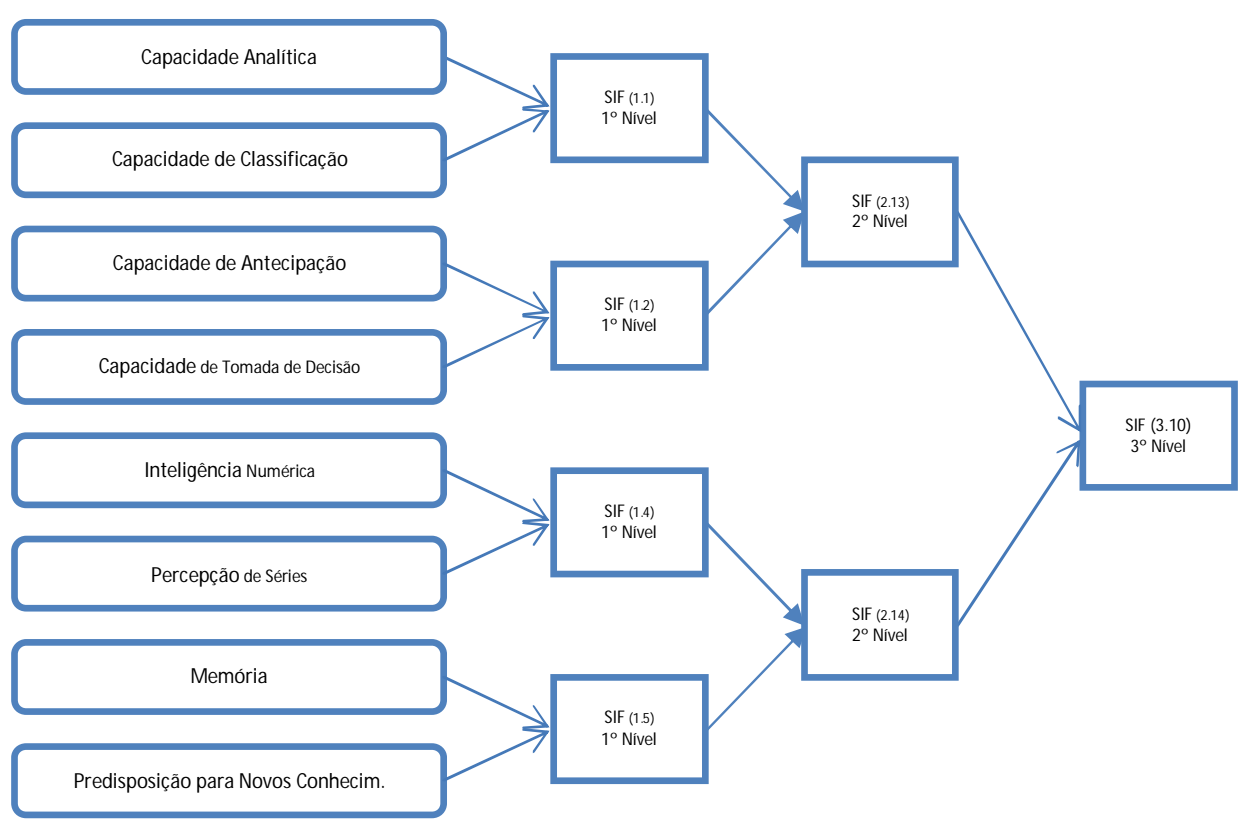

Figura 8: Agrupamento de SIFs hierárquicos remanescentes do primeiro nível

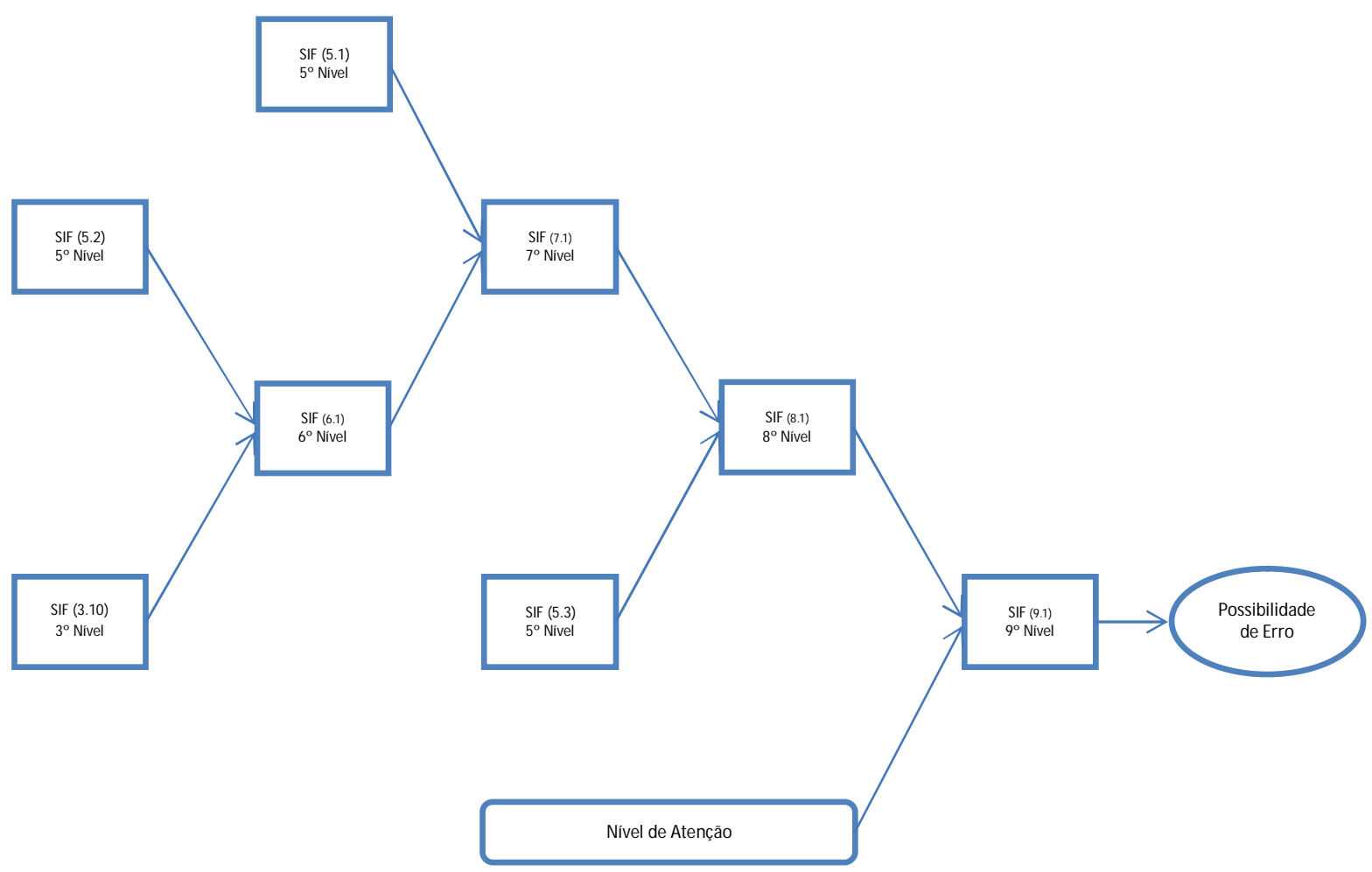

Figura 9: Agrupamento dos SIFs hierárquicos de terceiro e quinto nível até o último nível

A Figura 9 mostra como os SIFs 5.1, 5.2, 5.3, e 3.10 (Figuras 5, 6, 7 e 8) se relacionam para finalmente formarem o SIF final que calcula a possibilidade de erro total da tarefa (de causa humana). 


\section{4 .}

\section{Regras dos Sistemas de Inferência Fuzzy Hierárquicos}

Cada SIF definido anteriormente possui suas próprias regras fuzzy, responsáveis por determinar como um PSF influencia o(s) outro(s) que compõe(m) o SIF ao qual pertence. Como já explicado, cada tipo de erro contém regras diferentes para os mesmos PSF estudados.

Todas as 77 variáveis de entrada (PSF's), bem como as intermediárias (possibilidades de erro parcial) e a de saída (possibilidade de erro total) têm os mesmos conjuntos de termos lingüísticos (Baixo, Médio e Alto) e mesmo universo de valores (0\% a 100\%) como mostrado na Figura 10, ainda que as variáveis de entrada tratem de desempenho dos fatores, e as demais de possibilidade de erro.

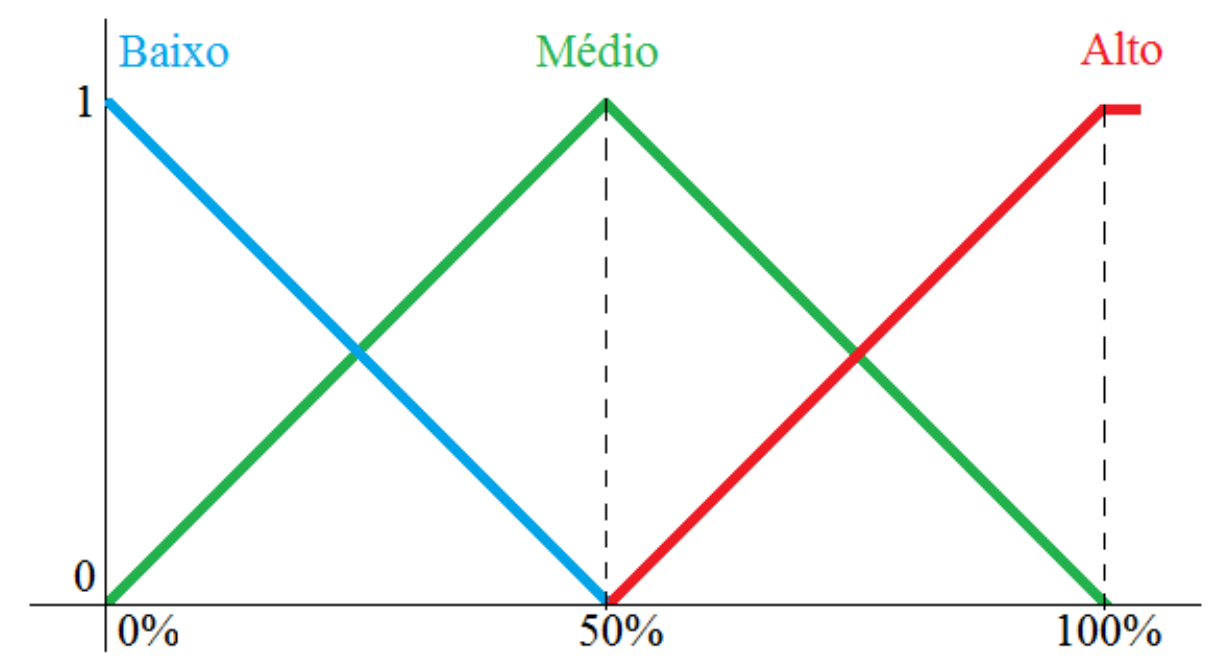

Figura 10: Gráfico representativo do universo de valores e dos conjuntos das variáveis fuzzy do sistema

Alguns PSFs são positivos, como é o caso de Comunicações. "Se Comunicações é Baixa (...)" é algo ruim, o ideal é que as comunicações entre equipes e entre funcionários e superiores sejam altas. Porém, outros são negativos, como o PSF Complexidade de Informações. O ideal seria que as informações fossem sempre as mais simples possíveis, para garantir o sucesso da tarefa e do processo como um todo.

Da mesma forma como alguns PSFs influenciam mais do que outros cada etapa da realização de uma tarefa (obtenção da Informação, planejamento/tomada 
de Decisão, execução da tarefa/Ação), alguns tem tão baixa influência que podem, e devem, ser considerados como indiferentes, uma vez que o objetivo do trabalho é identificar quais são os mais pertinentes para cada possibilidade de falha. A avaliação de quão importante é um PSF para a etapa analisada foi baseada no que (Hendrickson, 2010) considerou como crítico para o sucesso de cada uma delas.

\subsection{1. \\ Etapa Informação}

Como a etapa de Informação é tida como limitada quanto à demanda de fatores cognitivos e de fatores de personalidade, poucos deles foram considerados como potencialmente causadores de erro.

Os fatores indiferentes para esta etapa são: Capacidade Analítica, Capacidade de Classificação, Capacidade de Antecipação, Capacidade de Tomada de Decisões, Continuidade de matrizes ou conjuntos, Estruturação do campo perceptivo (topologia), Inteligência numérica (capacidade de cálculos), Percepção de séries, Agressão, Autonomia, Assistência, Deferência, Desempenho, Dominância, Exibição, Intracepção, Ordem e Persistência.

Os PSFs do Grupo Fatores de Stress Fisiológicos também são indiferentes nesta etapa, uma vez que não influenciam diretamente a obtenção de informação. Naturalmente, se mantida por longo prazo uma característica como Fome ou Sede, a capacidade de um empregado assimilar as informações necessárias para executar com sucesso uma tarefa será prejudicada. Mas o motivo pelo qual isso ocorre é por que outros PSFs influentes nesta etapa estão sendo afetados. Isto é: um PSF (que não influencia diretamente a Informação) influencia outro PSF. Estes últimos sendo os que de fato são pertinentes à Informação, e são avaliados independentemente da razão pela qual estão sendo mal desempenhados. Por exemplo: se um operador tem seu Ritmo Circadiano Interrompido, sua capacidade de obter a informação sobre como proceder será prejudicada por não lembrar do que lhe foi dito (abrangido pelo PSF Memória), ou por não ter prestado atenção no momento em que estava recebendo a informação (abrangido pelo PSF Nível de Atenção), ou até mesmo por estar distraído (abrangido pelo PSF Distrações). A influência de um PSF do Grupo Fatores de Stress Fisiológicos é indireta.

As regras para o tipo de erro Informação são exibidas a seguir. 


\subsubsection{1.}

\section{SIF's Hierárquicos do Primeiro Nível}

As regras abaixo exibem o relacionamento de dois ou três PSFs e o respectivo resultado. Devem ser lidas da seguinte maneira: "Se PSF-(primeira coluna) é desempenho-(segunda coluna) e PSF-(terceira coluna) é desempenho(quarta coluna) então Possibilidade de erro parcial é possibilidade-(quinta coluna). Exemplo: Se Memória é Baixa e Predisposição para novos conhecimentos é Baixa então Possibilidade de erro de informação parcial é Alta.

\begin{tabular}{|c|c|c|c|c|}
\hline Se & é & e & é & $\begin{array}{c}\text { Então } \\
\text { possibilidade } \\
\text { de erro de } \\
\text { Informação } \\
\text { é }\end{array}$ \\
\hline Memória & Baixa & $\begin{array}{c}\text { Predisposição para novos } \\
\text { conhecimentos }\end{array}$ & $*$ & Alta \\
\hline Memória & $*$ & $\begin{array}{c}\text { Predisposição para novos } \\
\text { conhecimentos }\end{array}$ & Baixa & Alta \\
\hline Memória & Média & $\begin{array}{c}\text { Predisposição para novos } \\
\text { conhecimentos }\end{array}$ & M édia & Média \\
\hline Memória & Média & $\begin{array}{c}\text { Predisposição para novos } \\
\text { conhecimentos }\end{array}$ & Alta & Baixa \\
\hline Memória & Alta & $\begin{array}{c}\text { Predisposição para novos } \\
\text { conhecimentos }\end{array}$ & M édia & Baixa \\
\hline Afago & Alto & Afiliação & $*$ & Alta \\
\hline Afago & $*$ & Afiliação & Baixa & Alta \\
\hline Afago & Média & Afiliação & Média & Média \\
\hline Afago & Média & Afiliação & Alta & Média \\
\hline Afago & Baixa & Afiliação & Média & Média \\
\hline Afago & Baixa & Alta & Baixa \\
\hline
\end{tabular}

Os PSFs Ameaças (de Falha, de Perda do Emprego, etc.); Falta de Recompensas, Reconhecimento e Benefícios; e Motivos Conflitantes sobre o Desempenho no Trabalho compõe um SIF de, evidentemente, três variáveis de entrada. Para serem mais bem exibidas, suas regras foram separadas em três grupos mostrados a seguir. 
Se o PSF Ameaças (de Falha, de Perda do Emprego, etc.) é Alto, o empregado está sob forte ameaça de falha e/ou de perda do emprego, e então, independentemente do desempenho dos outros dois PSFs, a possibilidade de erro de informação parcial relativa a este SIF é Alta. Isto ocorre por que a ameaça de perda de emprego é um fator constante, e não recorrente a curto prazo ou esporádico. Há uma indicação de que o empregado afetado por esse fator está sob desequilíbrio psicológico, inclusive no momento de receber a informação.

\begin{tabular}{|c|c|c|c|c|}
\hline $\begin{array}{c}\text { Falta de Recompensas, } \\
\text { Reconhecimento e } \\
\text { Benefícios }\end{array}$ & $*$ & $\begin{array}{c}\text { Motivos Conflitantes sobre } \\
\text { o Desempenho no Trabalho }\end{array}$ & $*$ & Alta \\
\hline
\end{tabular}

Caso o nível de ameaças seja Médio, as regras consideradas são as seguintes:

\begin{tabular}{|c|l|c|c|c|}
\hline $\begin{array}{c}\text { Falta de Recompensas, } \\
\text { Reconhecimento e } \\
\text { Benefícios }\end{array}$ & Baixa & $\begin{array}{c}\text { M otivos Conflitantes sobre } \\
\text { o Desempenho no } \\
\text { Trabalho }\end{array}$ & Baixo & M édia \\
\hline $\begin{array}{c}\text { Falta de Recompensas, } \\
\text { Reconhecimento e } \\
\text { Benefícios }\end{array}$ & Baixa & $\begin{array}{c}\text { M otivos Conflitantes sobre } \\
\text { o Desempenho no } \\
\text { Trabalho }\end{array}$ & Médio & M édia \\
\hline $\begin{array}{c}\text { Falta de Recompensas, } \\
\text { Reconhecimento e } \\
\text { Benefícios }\end{array}$ & Baixa & $\begin{array}{c}\text { Motivos Conflitantes sobre } \\
\text { o Desempenho no } \\
\text { Trabalho }\end{array}$ & Alto & M édia \\
\hline $\begin{array}{c}\text { Falta de Recompensas, } \\
\text { Reconhecimento e } \\
\text { Benefícios }\end{array}$ & Média & $\begin{array}{c}\text { Motivos Conflitantes sobre } \\
\text { o Desempenho no } \\
\text { Trabalho }\end{array}$ & Baixo & M édia \\
\hline $\begin{array}{c}\text { Falta de Recompensas, } \\
\text { Reconhecimento e } \\
\text { Benefícios }\end{array}$ & M édia & $\begin{array}{c}\text { Motivos Conflitantes sobre } \\
\text { o Desempenho no } \\
\text { Trabalho }\end{array}$ & Médio & M édia \\
\hline $\begin{array}{c}\text { Falta de Recompensas, } \\
\text { Reconhecimento e } \\
\text { Benefícios }\end{array}$ & Média & $\begin{array}{c}\text { Motivos Conflitantes sobre } \\
\text { o Desempenho no } \\
\text { Trabalho }\end{array}$ & Alto & Alta \\
\hline $\begin{array}{c}\text { Falta de Recompensas, } \\
\text { Reconhecimento e } \\
\text { Benefícios }\end{array}$ & Alta & $\begin{array}{c}\text { Motivos Conflitantes sobre } \\
\text { o Desempenho no } \\
\text { Trabalho }\end{array}$ & Baixo & M édia \\
\hline $\begin{array}{c}\text { Falta de Recompensas, } \\
\text { Reconhecimento e } \\
\text { Benefícios }\end{array}$ & Alta & $\begin{array}{c}\text { Motivos Conflitantes sobre } \\
\text { o Desempenho no } \\
\text { Trabalho }\end{array}$ & Médio & M édia \\
\hline $\begin{array}{c}\text { Falta de Recompensas, } \\
\text { Reconhecimento e } \\
\text { Benefícios }\end{array}$ & Alta & $\begin{array}{c}\text { Motivos Conflitantes sobre } \\
\text { o Desempenho no } \\
\text { Trabalho }\end{array}$ & Alto & Alta \\
\hline
\end{tabular}

Caso o nível de ameaças seja baixo, os demais fatores não são suficientes por si só para indicar uma possibilidade de erro significativa no momento da obtenção da informação, uma vez que o funcionário está tranqüilo no que diz 
respeito à sua estabilidade de emprego e capacidade de realizar a tarefa com sucesso.

\begin{tabular}{|c|c|c|c|c|}
\hline $\begin{array}{c}\text { Falta de Recompensas, } \\
\text { Reconhecimento e } \\
\text { Benefícios }\end{array}$ & $*$ & $\begin{array}{c}\text { Motivos Conflitantes sobre } \\
\text { o Desempenho no Trabalho }\end{array}$ & $*$ & Baixa \\
\hline
\end{tabular}

O PSF Carga Pesada de Informações, naturalmente, é um dos mais influentes para o tipo de erro aqui analisado. Dessa forma, pode-se perceber que sua importância é maior do que a de Início Inesperado do Stress.

\begin{tabular}{|c|c|c|c|c|}
\hline $\begin{array}{c}\text { Carga Pesada de } \\
\text { Informações }\end{array}$ & Baixa & Início Inesperado do Stress & Baixo & Baixa \\
\hline $\begin{array}{c}\text { Carga Pesada de } \\
\text { Informações }\end{array}$ & Baixa & Início Inesperado do Stress & M édio & Baixa \\
\hline $\begin{array}{c}\text { Carga Pesada de } \\
\text { Informações }\end{array}$ & Baixa & Início Inesperado do Stress & Alto & M édia \\
\hline $\begin{array}{c}\text { Carga Pesada de } \\
\text { Informações }\end{array}$ & Média & Início Inesperado do Stress & Baixo & M édia \\
\hline $\begin{array}{c}\text { Carga Pesada de } \\
\text { Informações }\end{array}$ & Média & Início Inesperado do Stress & M édio & M édia \\
\hline $\begin{array}{c}\text { Carga Pesada de } \\
\text { Informações }\end{array}$ & Média & Início Inesperado do Stress & Alto & Alta \\
\hline $\begin{array}{c}\text { Carga Pesada de } \\
\text { Informações }\end{array}$ & Alta & Início Inesperado do Stress & Baixo & Alta \\
\hline $\begin{array}{c}\text { Carga Pesada de } \\
\text { Informações }\end{array}$ & Alta & Início Inesperado do Stress & Médio & Alta \\
\hline $\begin{array}{c}\text { Carga Pesada de } \\
\text { Informações }\end{array}$ & Alta & Início Inesperado do Stress & Alto & Alta \\
\hline
\end{tabular}

Uma distração no momento do recebimento da informação pode ser impeditiva para o sucesso da tarefa. A perda de sensibilidade é mais pertinente ao momento da realização da tarefa propriamente dita (Ação). 


\begin{tabular}{|c|c|c|c|c|}
\hline $\begin{array}{c}\text { Distrações (devido a Ruído, } \\
\text { Clarão, M ovimentos, etc.) }\end{array}$ & Baixa & Perda de Sensibilidade & Baixa & Baixa \\
\hline $\begin{array}{c}\text { Distrações (devido a Ruído, } \\
\text { Clarão, M ovimentos, etc.) }\end{array}$ & Baixa & Perda de Sensibilidade & Média & Baixa \\
\hline $\begin{array}{c}\text { Distrações (devido a Ruído, } \\
\text { Clarão, M ovimentos, etc.) }\end{array}$ & Baixa & Perda de Sensibilidade & Alta & Média \\
\hline $\begin{array}{c}\text { Distrações (devido a Ruído, } \\
\text { Clarão, M ovimentos, etc.) }\end{array}$ & Média & Perda de Sensibilidade & Baixa & M édia \\
\hline $\begin{array}{c}\text { Distrações (devido a Ruído, } \\
\text { Clarão, M ovimentos, etc.) }\end{array}$ & Média & Perda de Sensibilidade & Média & Média \\
\hline $\begin{array}{c}\text { Distrações (devido a Ruído, } \\
\text { Clarão, M ovimentos, etc.) }\end{array}$ & Média & Perda de Sensibilidade & Alta & Alta \\
\hline $\begin{array}{c}\text { Distrações (devido a Ruído, } \\
\text { Clarão, M ovimentos, etc.) }\end{array}$ & Alta & Perda de Sensibilidade & Baixa & Alta \\
\hline $\begin{array}{c}\text { Distrações (devido a Ruído, } \\
\text { Clarão, M ovimentos, etc.) }\end{array}$ & Alta & Perda de Sensibilidade & Média & Alta \\
\hline $\begin{array}{c}\text { Distraç̃̃es (devido a Ruído, } \\
\text { Clarão, M ovimentos, etc.) }\end{array}$ & Alta & Perda de Sensibilidade & Alta & Alta \\
\hline
\end{tabular}

\begin{tabular}{|c|c|c|c|c|}
\hline $\begin{array}{l}\text { Períodos de Vigilância } \\
\text { Longos, sem } \\
\text { Acontecimentos }\end{array}$ & Baixa & $\begin{array}{c}\text { Trabalho M onótono, } \\
\text { Degradante ou Sem } \\
\text { Sentido }\end{array}$ & Baixa & Baixa \\
\hline $\begin{array}{l}\text { Períodos de Vigilância } \\
\text { Longos, sem } \\
\text { Acontecimentos }\end{array}$ & Baixa & $\begin{array}{c}\text { Trabalho M onótono, } \\
\text { Degradante ou Sem } \\
\text { Sentido }\end{array}$ & Média & Baixa \\
\hline $\begin{array}{l}\text { Períodos de Vigilância } \\
\text { Longos, sem } \\
\text { Acontecimentos }\end{array}$ & Baixa & $\begin{array}{l}\text { Trabalho M onótono, } \\
\text { Degradante ou Sem } \\
\text { Sentido }\end{array}$ & Alta & Média \\
\hline $\begin{array}{l}\text { Períodos de Vigilância } \\
\text { Longos, sem } \\
\text { Acontecimentos }\end{array}$ & Média & $\begin{array}{c}\text { Trabalho M onótono, } \\
\text { Degradante ou Sem } \\
\text { Sentido }\end{array}$ & Baixa & Baixa \\
\hline $\begin{array}{l}\text { Períodos de Vigilância } \\
\text { Longos, sem } \\
\text { Acontecimentos }\end{array}$ & M édia & $\begin{array}{c}\text { Trabalho M onótono, } \\
\text { Degradante ou Sem } \\
\text { Sentido }\end{array}$ & Média & Média \\
\hline $\begin{array}{l}\text { Períodos de Vigilância } \\
\text { Longos, sem } \\
\text { Acontecimentos }\end{array}$ & M édia & $\begin{array}{c}\text { Trabalho M onótono, } \\
\text { Degradante ou Sem } \\
\text { Sentido }\end{array}$ & Alta & Alta \\
\hline $\begin{array}{l}\text { Períodos de Vigilância } \\
\text { Longos, sem } \\
\text { Acontecimentos }\end{array}$ & Alta & $\begin{array}{c}\text { Trabalho M onótono, } \\
\text { Degradante ou Sem } \\
\text { Sentido }\end{array}$ & Baixa & Média \\
\hline $\begin{array}{l}\text { Períodos de Vigilância } \\
\text { Longos, sem } \\
\text { Acontecimentos }\end{array}$ & Alta & $\begin{array}{c}\text { Trabalho M onótono, } \\
\text { Degradante ou Sem } \\
\text { Sentido }\end{array}$ & Média & Alta \\
\hline $\begin{array}{l}\text { Períodos de Vigilância } \\
\text { Longos, sem } \\
\text { Acontecimentos }\end{array}$ & Alta & $\begin{array}{l}\text { Trabalho M onótono, } \\
\text { Degradante ou Sem } \\
\text { Sentido }\end{array}$ & Alta & Alta \\
\hline
\end{tabular}




\begin{tabular}{|c|c|c|c|c|}
\hline Reforço Negativo & Baixa & Sugestões Inconsistentes & Baixa & Baixa \\
\hline Reforço Negativo & Baixa & Sugestões Inconsistentes & Média & M édia \\
\hline Reforço Negativo & Baixa & Sugestões Inconsistentes & Alta & Alta \\
\hline Reforço Negativo & Média & Sugestões Inconsistentes & Baixa & M édia \\
\hline Reforço Negativo & Média & Sugestões Inconsistentes & Média & M édia \\
\hline Reforço Negativo & Média & Sugestões Inconsistentes & Alta & Alta \\
\hline Reforço Negativo & Alta & Sugestões Inconsistentes & Baixa & Alta \\
\hline Reforço Negativo & Alta & Sugestões Inconsistentes & Média & Alta \\
\hline Reforço Negativo & Alta & Sugestões Inconsistentes & Alta & Alta \\
\hline
\end{tabular}

O PSF Comunicação é essencial nesta etapa; portanto, se ele está sendo mal desempenhado, a etapa terá alta possibilidade de falhar.

\begin{tabular}{|c|c|c|c|c|}
\hline $\begin{array}{l}\text { Ações desenvolvidas por } \\
\text { Supervisores, Colegas, } \\
\text { Representantes de } \\
\text { Sindicatos, e Pessoal de } \\
\text { Regulamentação }\end{array}$ & $*$ & Comunicação & Baixa & Alta \\
\hline $\begin{array}{l}\text { Ações desenvolvidas por } \\
\text { Supervisores, Colegas, } \\
\text { Representantes de } \\
\text { Sindicatos, e Pessoal de } \\
\text { Regulamentação }\end{array}$ & Baixa & Comunicação & Média & Média \\
\hline $\begin{array}{l}\text { Ações desenvolvidas por } \\
\text { Supervisores, Colegas, } \\
\text { Representantes de } \\
\text { Sindicatos, e Pessoal de } \\
\text { Regulamentação }\end{array}$ & Baixa & Comunicação & Alta & Média \\
\hline $\begin{array}{l}\text { Ações desenvolvidas por } \\
\text { Supervisores, Colegas, } \\
\text { Representantes de } \\
\text { Sindicatos, e Pessoal de } \\
\text { Regulamentação }\end{array}$ & Média & Comunicação & Média & Média \\
\hline $\begin{array}{l}\text { Ações desenvolvidas por } \\
\text { Supervisores, Colegas, } \\
\text { Representantes de } \\
\text { Sindicatos, e Pessoal de } \\
\text { Regulamentação }\end{array}$ & Média & Comunicação & Alta & Baixa \\
\hline $\begin{array}{l}\text { Ações desenvolvidas por } \\
\text { Supervisores, Colegas, } \\
\text { Representantes de } \\
\text { Sindicatos, e Pessoal de } \\
\text { Regulamentação }\end{array}$ & Alta & Comunicação & Média & Baixa \\
\hline $\begin{array}{l}\text { Ações desenvolvidas por } \\
\text { Superv., Colegas, Repr. de } \\
\text { Sindicatos, e Pessoal de } \\
\text { Regulamentação }\end{array}$ & Alta & Comunicação & Alta & Baixa \\
\hline
\end{tabular}


Os fatores Capacidade Crítica da Tarefa e Complexidade da Tarefa são críticos nesta etapa. Qualquer um que esteja Alto fará com que a possibilidade de falha parcial resultante também seja Alta.

\begin{tabular}{|c|c|c|c|c|}
\hline $\begin{array}{c}\text { Capacidade Crítica da } \\
\text { Tarefa }\end{array}$ & Baixa & $\begin{array}{c}\text { Complexidade da Tarefa } \\
\text { (Carga de Informações) }\end{array}$ & Baixa & Baixa \\
\hline $\begin{array}{c}\text { Capacidade Crítica da } \\
\text { Tarefa }\end{array}$ & Baixa & $\begin{array}{c}\text { Complexidade da Tarefa } \\
\text { (Carga de Informações) }\end{array}$ & M édia & M édia \\
\hline $\begin{array}{c}\text { Capacidade Crítica da } \\
\text { Tarefa }\end{array}$ & $*$ & $\begin{array}{c}\text { Complexidade da Tarefa } \\
\text { (Carga de Informações) }\end{array}$ & Alta & Alta \\
\hline $\begin{array}{c}\text { Capacidade Crítica da } \\
\text { Tarefa }\end{array}$ & Média & $\begin{array}{c}\text { Complexidade da Tarefa } \\
\text { (Carga de Informações) }\end{array}$ & Baixa & Baixa \\
\hline $\begin{array}{c}\text { Capacidade Crítica da } \\
\text { Tarefa }\end{array}$ & Média & $\begin{array}{c}\text { Complexidade da Tarefa } \\
\text { (Carga de Informações) }\end{array}$ & Média & M édia \\
\hline $\begin{array}{c}\text { Capacidade Crítica da } \\
\text { Tarefa }\end{array}$ & Alta & $\begin{array}{c}\text { Complexidade da Tarefa } \\
\text { (Carga de Informações) }\end{array}$ & $*$ & Alta \\
\hline
\end{tabular}

Alguns PSFs do Grupo Fatores Externos são indiferentes para a Informação: Cuidados e Advertências, Fatores de Interface de Hardware, Disponibilidade de Equipamentos Especiais, Instrumentos, Insumos, Freqüência e Repetitividade da Tarefa, Horas de Trabalho/Intervalos de Trabalho, Quantidade de Pessoal e Rodízio de Turnos.

\begin{tabular}{|c|c|c|c|c|}
\hline Estrutura de Equipe & Baixa & Estrutura Organizacional & Baixa & Alta \\
\hline Estrutura de Equipe & Baixa & Estrutura Organizacional & Média & Alta \\
\hline Estrutura de Equipe & Baixa & Estrutura Organizacional & Alta & Alta \\
\hline Estrutura de Equipe & Média & Estrutura Organizacional & Baixa & Alta \\
\hline Estrutura de Equipe & Média & Estrutura Organizacional & Média & M édia \\
\hline Estrutura de Equipe & Média & Estrutura Organizacional & Alta & Baixa \\
\hline Estrutura de Equipe & Alta & Estrutura Organizacional & Baixa & Alta \\
\hline Estrutura de Equipe & Alta & Estrutura Organizacional & Média & Baixa \\
\hline Estrutura de Equipe & Alta & Estrutura Organizacional & Alta & Baixa \\
\hline
\end{tabular}

Um conhecimento equivocado, ou melhor, o desconhecimento das políticas e métodos pode prejudicar diretamente a assimilação da informação por parte do empregado. A simulação mental (Hendrick, 2010) do que o funcionário espera receber de informação gera uma expectativa do que está prestes a lhe ser transmitido. Se esta expectativa for errônea/discrepante da realidade, a informação, ainda que transmitida corretamente, pode ser mal interpretada/entendida de outra maneira. 


\begin{tabular}{|c|c|c|c|c|}
\hline Métodos de Trabalho & Baixo & Políticas da Planta & Baixa & Alta \\
\hline Métodos de Trabalho & Baixo & Políticas da Planta & Média & Alta \\
\hline Métodos de Trabalho & Baixo & Políticas da Planta & Alta & M édia \\
\hline Métodos de Trabalho & Médio & Políticas da Planta & Baixa & Alta \\
\hline Métodos de Trabalho & Médio & Políticas da Planta & Média & M édia \\
\hline Métodos de Trabalho & Médio & Políticas da Planta & Alta & Baixa \\
\hline Métodos de Trabalho & Alto & Políticas da Planta & Baixa & M édia \\
\hline Métodos de Trabalho & Alto & Políticas da Planta & Média & Baixa \\
\hline Métodos de Trabalho & Alto & Políticas da Planta & Alta & Baixa \\
\hline
\end{tabular}

Procedimentos (escritos ou não) influenciam a Informação, principalmente por se constituírem em um método de transmiti-la. A ausência de Feedback dos resultados das tarefas anteriores também pode prejudicar diretamente a obtenção da informação, uma vez que isto afeta a segurança interna/confiança do empregado na realização de suas funções, prejudicando assim a sua simulação mental.

\begin{tabular}{|c|c|c|c|c|}
\hline $\begin{array}{c}\text { Feedback (Conhecimento } \\
\text { de Resultados) }\end{array}$ & Baixo & $\begin{array}{c}\text { Procedimentos (Escritos ou } \\
\text { Não Escritos) }\end{array}$ & Baixo & Alta \\
\hline $\begin{array}{c}\text { Feedback (Conhecimento } \\
\text { de Resultados) }\end{array}$ & Baixo & $\begin{array}{c}\text { Procedimentos (Escritos ou } \\
\text { Não Escritos) }\end{array}$ & M édio & Alta \\
\hline $\begin{array}{c}\text { Feedback (Conhecimento } \\
\text { de Resultados) }\end{array}$ & Baixo & $\begin{array}{c}\text { Procedimentos (Escritos ou } \\
\text { Não Escritos) }\end{array}$ & Alto & M édia \\
\hline $\begin{array}{c}\text { Feedback (Conhecimento } \\
\text { de Resultados) }\end{array}$ & Médio & $\begin{array}{c}\text { Procedimentos (Escritos ou } \\
\text { Não Escritos) }\end{array}$ & Baixo & Alta \\
\hline $\begin{array}{c}\text { Feedback (Conhecimento } \\
\text { de Resultados) }\end{array}$ & Médio & $\begin{array}{c}\text { Procedimentos (Escritos ou } \\
\text { Não Escritos) }\end{array}$ & M édio & M édia \\
\hline $\begin{array}{c}\text { Feedback (Conhecimento } \\
\text { de Resultados) }\end{array}$ & Médio & $\begin{array}{c}\text { Procedimentos (Escritos ou } \\
\text { Não Escritos) }\end{array}$ & Alto & Baixa \\
\hline $\begin{array}{c}\text { Feedback (Conhecimento } \\
\text { de Resultados) }\end{array}$ & Alto & $\begin{array}{c}\text { Procedimentos (Escritos ou } \\
\text { Não Escritos) }\end{array}$ & Baixo & Alta \\
\hline $\begin{array}{c}\text { Feedback (Conhecimento } \\
\text { de Resultados) }\end{array}$ & Alto & $\begin{array}{c}\text { Procedimentos (Escritos ou } \\
\text { Não Escritos) }\end{array}$ & M édio & Baixa \\
\hline $\begin{array}{c}\text { Feedback (Conhecimento } \\
\text { de Resultados) }\end{array}$ & Alto & $\begin{array}{c}\text { Procedimentos (Escritos ou } \\
\text { Não Escritos) }\end{array}$ & Alto & Baixa \\
\hline
\end{tabular}

O PSF Influência de Outros Agentes Externos (pessoas, família) poderia ser considerado como positivo ou negativo no desempenho humano. Se fosse considerado negativo, significaria que uma Alta influência resultaria em fortes variações no desempenho do funcionário, porém dificultaria a associação com a qualidade dessa influencia. Não se pode dizer que todas as influências externas 
são necessariamente ruins (da mesma forma como não se pode dizer que são necessariamente boas). Dessa forma, decidiu-se considerar que uma influência alta é algo bom. Como se a influencia que a família vem causando é boa/positiva, ou ainda que o funcionário não se deixa influenciar - indica que o funcionário é capaz de separar trabalho de vida pessoal. Outra maneira válida para solucionar o problema seria separar o PSF em dois: "Quão Influenciado Por Agentes Externos O Funcionário É"; e "Como Vem Se Comportando No Funcionário As Influências Atuais".

Ambos PSF's aqui avaliados são importantes e é inegável que sua influência deve ser considerada na caracterização da confiabilidade humana em diversas tarefas, porém é imprescindível observar que são extremamente voláteis. Condição Física/Saúde engloba doenças, que tem os mais variados períodos de duração e sintomas prejudiciais ao desempenho humano. Se o problema de saúde danificar, mesmo que temporariamente, os sentidos da visão ou da audição, o recebimento da informação será diretamente comprometido. Ainda, deve-se considerar que o funcionário pode muitas vezes não estar trabalhando caso alguma condição de saúde grave o afete (o que influenciaria o PSF "Quantidade de Pessoal"). Analogamente, influências da família podem variar abruptamente de um dia para outro.

\begin{tabular}{|c|c|c|c|c|}
\hline Condição Física/Saúde & Baixa & $\begin{array}{c}\text { Influência de Outros } \\
\text { Agentes Externos (pessoas, } \\
\text { família) }\end{array}$ & $*$ & Alta \\
\hline Condição Física/Saúde & $*$ & $\begin{array}{c}\text { Influência de outros } \\
\text { agentes externos (pessoas, } \\
\text { família) }\end{array}$ & Baixa & Alta \\
\hline Condição Física/Saúde & Média & $\begin{array}{c}\text { Influência de outros } \\
\text { agentes externos (pessoas, } \\
\text { família) }\end{array}$ & Média & M édia \\
\hline Condição Física/Saúde & Média & $\begin{array}{c}\text { Influência de outros } \\
\text { agentes externos (pessoas, } \\
\text { família) }\end{array}$ & Alta & Baixa \\
\hline Condição Física/Saúde & Alta & $\begin{array}{c}\text { Influência de outros } \\
\text { agentes externos (pessoas, } \\
\text { família) }\end{array}$ & Média & Baixa \\
\hline Condição Física/Saúde & Alta & $\begin{array}{c}\text { Influência de outros } \\
\text { agentes externos (pessoas, } \\
\text { família) }\end{array}$ & Alta & Baixa \\
\hline
\end{tabular}

Da mesma maneira que os PSF's Métodos de Trabalho, Políticas da Planta, e Feedback (Conhecimento de Resultados) afetam a Informação, os PSF's das 
regras abaixo também o fazem. A predisposição a ouvir/receber aquilo que se espera com base em experiências passadas, bem como em vícios de trabalho, é inevitável. Contudo, se estes PSF's tiverem bom comportamento no funcionário a tarefa terá alta chance de ser bem sucedida.

\begin{tabular}{|c|c|c|c|c|}
\hline $\begin{array}{c}\text { Conhecimento de Padrões } \\
\text { de Desempenho }\end{array}$ & Baixo & Experiência & Baixa & Alta \\
\hline $\begin{array}{c}\text { Conhecimento de Padrões } \\
\text { de Desempenho }\end{array}$ & Baixo & Experiência & M édia & Alta \\
\hline $\begin{array}{c}\text { Conhecimento de Padrões } \\
\text { de Desempenho }\end{array}$ & Baixo & Experiência & Alta & M édia \\
\hline $\begin{array}{c}\text { Conhecimento de Padrões } \\
\text { de Desempenho }\end{array}$ & Médio & Experiência & Baixa & Alta \\
\hline $\begin{array}{c}\text { Conhecimento de Padrões } \\
\text { de Desempenho }\end{array}$ & Médio & Experiência & Média & M édia \\
\hline $\begin{array}{c}\text { Conhecimento de Padrões } \\
\text { de Desempenho }\end{array}$ & Médio & Experiência & Alta & Baixa \\
\hline $\begin{array}{c}\text { Conhecimento de Padrões } \\
\text { de Desempenho }\end{array}$ & Alto & Experiência & Baixa & M édia \\
\hline $\begin{array}{c}\text { Conhecimento de Padrões } \\
\text { de Desempenho }\end{array}$ & Alto & Experiência & Média & Baixa \\
\hline $\begin{array}{c}\text { Conhecimento de Padrões } \\
\text { de Desempenho }\end{array}$ & Alto & Experiência & Alta & Baixa \\
\hline
\end{tabular}

Ambos PSF's do SIF abaixo influenciam diretamente todas as fases relativas a execução de uma tarefa. Motivação é um fator interno que tem a propriedade de causar forte impacto nos fatores do Grupo de PSF's de Personalidade.

Tensão física não tem influência direta no recebimento da informação. Já Tensão Mental influencia todas as etapas: pode aumentar a ocorrência de lapsos/deslizes, bem como alterar a "working memory" e a capacidade do funcionário de perceber e observar quais variáveis são pertinentes à tarefa que está prestes a executar ou receber.

\begin{tabular}{|c|c|c|c|c|}
\hline Motivação & Baixa & Tensão Mental ou Física & Baixa & M édia \\
\hline Motivação & Baixa & Tensão M ental ou Física & Média & Alta \\
\hline Motivação & Baixa & Tensão M ental ou Física & Alta & Alta \\
\hline Motivação & Média & Tensão Mental ou Física & Baixa & Baixa \\
\hline Motivação & Média & Tensão M ental ou Física & Média & M édia \\
\hline Motivação & Média & Tensão Mental ou Física & Alta & Alta \\
\hline Motivação & Alta & Tensão Mental ou Física & Baixa & Baixa \\
\hline Motivação & Alta & Tensão Mental ou Física & Média & Baixa \\
\hline Motivação & Alta & Tensão Mental ou Física & Alta & M édia \\
\hline
\end{tabular}


Nível de Cultura de Segurança define como o funcionário "enxerga" o que lhe está sendo passado e como aquilo se encaixa sob a ótica da empresa. Nível de Cultura Organizacional mal desempenhado, no que diz respeito à etapa atual, engloba desconhecer meios de comunicação e quais Métodos de Trabalho são mais propícios.

\begin{tabular}{|c|l|c|c|c|}
\hline $\begin{array}{c}\text { Nível de Cultura de } \\
\text { Segurança }\end{array}$ & Baixo & $\begin{array}{c}\text { Nível de Cultura } \\
\text { Organizacional }\end{array}$ & Baixo & Alta \\
\hline $\begin{array}{c}\text { Nível de Cultura de } \\
\text { Segurança }\end{array}$ & Baixo & $\begin{array}{c}\text { Nível de Cultura } \\
\text { Organizacional }\end{array}$ & M édio & Alta \\
\hline $\begin{array}{c}\text { Nível de Cultura de } \\
\text { Segurança }\end{array}$ & Baixo & $\begin{array}{c}\text { Nível de Cultura } \\
\text { Organizacional }\end{array}$ & Alto & M édia \\
\hline $\begin{array}{c}\text { Nível de Cultura de } \\
\text { Segurança }\end{array}$ & M édio & $\begin{array}{c}\text { Nível de Cultura } \\
\text { Organizacional }\end{array}$ & Baixo & Alta \\
\hline $\begin{array}{c}\text { Nível de Cultura de } \\
\text { Segurança }\end{array}$ & M édio & $\begin{array}{c}\text { Nível de Cultura } \\
\text { Organizacional }\end{array}$ & Médio & M édia \\
\hline $\begin{array}{c}\text { Nível de Cultura de } \\
\text { Segurança }\end{array}$ & M édio & $\begin{array}{c}\text { Nível de Cultura } \\
\text { Organizacional }\end{array}$ & Alto & Baixa \\
\hline $\begin{array}{c}\text { Nível de Cultura de } \\
\text { Segurança }\end{array}$ & Altol de Cultura & Organizacional & M édia \\
\hline $\begin{array}{c}\text { Nível de Cultura de } \\
\text { Segurança }\end{array}$ & Alto & $\begin{array}{c}\text { Nível de Cultura } \\
\text { Organizacional }\end{array}$ & Médio & Baixa \\
\hline $\begin{array}{c}\text { Nível de Cultura de } \\
\text { Segurançana }\end{array}$ & Altura & Alto & Baixa \\
\hline
\end{tabular}

Os PSF's Qualidade do Treinamento e Nível de Práticas afetam como o funcionário espera receber a informação indiretamente, sendo melhor avaliado pelo PSF Conhecimento de Padrões de Desempenho, por isso são considerados como indiferente para a Informação, com o objetivo de não super-valorizar tal quesito.

\subsubsection{2.}

\section{SIF's Hierárquicos do Segundo Nível}

Similarmente à seção anterior, esta exibe o relacionamento de dois ou três saídas dos SIFs hierárquicos do primeiro nível e o resultado respectivo. A diferença reside em que todas as variáveis são possibilidades de erro e não mais desempenho dos PSFs, então uma variável estar com comportamento Baixo indica que a possibilidade de seus PSF's falharem é pequena, portanto é uma avaliação positiva para a tarefa.

Como os PSFs de Personalidade Agressão e Autonomia são considerados como indiferentes para a obtenção da informação, a possibilidade de erro parcial 
deste sub-grupo só depende da possibilidade de erro parcial do sub-grupo dos PSFs Afago e Afiliação.

\begin{tabular}{|c|c|c|c|c|}
\hline $\begin{array}{c}\text { Se possibilidade de erro } \\
\text { de Informação do Sub- } \\
\text { grupo }\end{array}$ & é & $\begin{array}{c}\text { Então } \\
\text { e possibilidade de erro de } \\
\text { Informação do Sub-grupo }\end{array}$ & é & $\begin{array}{c}\text { possibilidade } \\
\text { de erro de } \\
\text { Informação } \\
\text { é }\end{array}$ \\
\hline $\begin{array}{c}\text { Afago } \\
\text { Afiliação }\end{array}$ & Baixa & $\begin{array}{c}\text { Agressão } \\
\text { Autonomia }\end{array}$ & Ind. & Baixa \\
\hline $\begin{array}{c}\text { Afago } \\
\text { Afiliação }\end{array}$ & Média & $\begin{array}{c}\text { Agressão } \\
\text { Autonomia }\end{array}$ & Ind. & M édia \\
\hline Afago & Alta & Agressão & Ind. & Alta \\
\hline Afiliação & Autonomia & & \\
\hline
\end{tabular}

Analogamente ao sub-grupo anterior, os PSFs Inteligência Numérica e Percepção de Séries são indiferentes para a Informação.

\begin{tabular}{|c|c|c|c|c|}
\hline $\begin{array}{c}\text { Inteligência Numérica } \\
\text { (capacidade de cálculos) } \\
\text { Percepção de Séries }\end{array}$ & Ind. & $\begin{array}{c}\text { Memória } \\
\text { Predisposição para Novos } \\
\text { Conhecimentos }\end{array}$ & Baixa & Baixa \\
\hline $\begin{array}{c}\text { Inteligência Numérica } \\
\text { (capacidade de cálculos) } \\
\text { Percepção de Séries }\end{array}$ & Ind. & $\begin{array}{c}\text { Memória } \\
\text { Predisposição para Novos } \\
\text { Conhecimentos }\end{array}$ & Média & Média \\
\hline $\begin{array}{c}\text { Inteligência Numérica } \\
\text { (capacidade de cálculos) } \\
\text { Percepção de Séries }\end{array}$ & Ind. & $\begin{array}{c}\text { Memória } \\
\text { Predisposição para Novos } \\
\text { Conhecimentos }\end{array}$ & Alta & Alta \\
\hline
\end{tabular}

Ambos sub-grupos possuem PSFs de alta influência na Informação: o PSF Ameaças em um; e o Carga Pesada de Informações em outro. Dessa forma, salvo o caso em que os dois sub-grupo indiquem possibilidade de falha Baixa, uma possibilidade de falha significativa será resultante deste SIF de segundo nível. 


\begin{tabular}{|c|c|c|c|c|}
\hline $\begin{array}{l}\text { Ameaças (de Falha, de } \\
\text { Perda do Emprego, etc.) } \\
\text { Falta de Recompensas, } \\
\text { Reconhecimento e } \\
\text { Benefícios } \\
\text { Motivos Conflitantes sobre } \\
\text { o Desempenho no Trabalho }\end{array}$ & Baixa & $\begin{array}{l}\text { Carga Pesada de } \\
\text { Informações } \\
\text { Início Inesperado do Stress }\end{array}$ & Baixa & Baixa \\
\hline II & Baixa & II & Média & Média \\
\hline II & Baixa & II & Alta & Média \\
\hline II & Média & II & Baixa & Média \\
\hline II & Média & II & Média & Média \\
\hline II & Média & II & Alta & Alta \\
\hline II & Alta & II & Baixa & Média \\
\hline II & Alta & II & Média & Alta \\
\hline II & Alta & II & Alta & Alta \\
\hline
\end{tabular}

Os PSFs Reforço Negativo e Sugestões Inconsistentes são um pouco mais pertinentes à Informação do que os do outro sub-grupo, sendo assim sua influência no resultado deste SIF será suavemente maior.

\begin{tabular}{|c|c|c|c|c|}
\hline Reforço Negativo & Baixa & $\begin{array}{c}\text { Períodos de Vigilância } \\
\text { Longos, sem } \\
\text { Acontecimentos } \\
\text { Trabalho Monótono, } \\
\text { Degradante ou Sem } \\
\text { Sentido }\end{array}$ & Baixa & Baixa \\
\hline II Inconsistentes & Baixa & II & Média & Baixa \\
\hline II & Baixa & II & Alta & M édia \\
\hline II & Média & II & Baixa & M édia \\
\hline II & Média & II & Média & M édia \\
\hline II & Média & II & Alta & Alta \\
\hline II & Alta & II & Baixa & M édia \\
\hline II & Alta & II & Média & Alta \\
\hline II & Alta & II & Alta & Alta \\
\hline
\end{tabular}

A Comunicação, obviamente, é o fator mais influente para a obtenção de informação. Seu sub-grupo é, portanto, mais representativo neste SIF. 


\begin{tabular}{|c|c|c|c|c|}
\hline $\begin{array}{c}\text { Ações desenvolvidas por } \\
\text { Supervisores, Colegas, } \\
\text { Representantes de } \\
\begin{array}{c}\text { Sindicatos, e Pessoal de } \\
\text { Regulamentação } \\
\text { Comunicação }\end{array}\end{array}$ & Baixa & Estrutura de Equipe & Baixa & Baixa \\
\hline II & Baixa & Estrutura Organizacional & & \\
\hline II & Baixa & II & Média & M édia \\
\hline II & Média & II & Alta & Alta \\
\hline II & Média & II & Baixa & M édia \\
\hline II & Média & II & Média & M édia \\
\hline II & Alta & II & Alta \\
\hline II & Alta & II & Baixa & Alta \\
\hline II & Alta & II édia & Alta \\
\hline & & & Alta & Alta \\
\hline
\end{tabular}

No sub-gupo do segundo nível que trata dos PSFs Métodos de Trabalho, Políticas da Planta, Feedback (Conhecimento de Resultados), e Procedimentos (Escritos ou Não Escritos) também considera os PSFs Cuidados e Advertências e Fatores de Interface de Hardware. Porém, estes dois últimos são indiferentes para o quesito Informação.

Neste SIF, é incoerente ou raro que exista algum funcionário que pertença simultaneamente a um grupo que indique baixa possibilidade e outro que indique alta possibilidade. Não é factível alguém conhecer os Métodos de Trabalho e as Políticas da Planta enquanto não possui boa noção de quais são os Procedimentos corretos. Porém, apenas para evitar o não tratamento de um eventual caso, a possibilidade Média foi determinada para esta situação. Média se aplica melhor, pois se está dizendo que ambos os sub-grupos tem mesmo grau de importância para este SIF, ainda que na prática provavelmente este caso não venha a ocorrer.

\begin{tabular}{|c|c|c|c|c|}
\hline Métodos de Trabalho & Baixa & $\begin{array}{c}\text { Feedback (Conhecimento } \\
\text { de Resultados) } \\
\text { Procedimentos (Escritos ou } \\
\text { Não Escritos) }\end{array}$ & Baixa & Baixa \\
\hline II & Baixa & II & Média & Baixa \\
\hline II & Baixa & II & Alta & M édia \\
\hline II & Média & II & Baixa & Baixa \\
\hline II & Média & II & Média & M édia \\
\hline II & Média & II & Alta & Alta \\
\hline II & Alta & II & Baixa & M édia \\
\hline II & Alta & II & Média & Alta \\
\hline II & Alta & II & Alta & Alta \\
\hline
\end{tabular}


Similarmente ao SIF anterior, é pouco provável que um funcionário esteja com Condição Física/Saúde ruim e ainda mantenha Tensão Mental ou Física boa. Da mesma forma que não é condizente com a realidade ter a Influência de outros agentes externos lhe causando forte impacto negativo e permanecer com Motivação alta. Para efeitos de boas práticas, caso este trabalho venha a ser de fato comercializado, se faz necessário implementar um alerta ao usuário para que seja verificado a possibilidade de o funcionário não ter tido seus PSFs avaliados corretamente. De qualquer maneira, estes casos são aqui tratados, ainda que consciente de sua baixa probabilidade de ocorrência.

\begin{tabular}{|c|c|c|c|c|}
\hline $\begin{array}{c}\text { Condição Física/Saúde } \\
\text { Influência de outros } \\
\text { agentes externos (pessoas, } \\
\text { família) }\end{array}$ & Baixa & Motivação & Baixa & Baixa \\
\hline II & Baixa & II & Mental ou Física & M édia \\
\hline II & Baixa & II & Alta & M édia \\
\hline II & Média & II & Baixa & Baixa \\
\hline II & Média & II & Média & Média \\
\hline II & Média & II & Alta & Alta \\
\hline II & Alta & II & Baixa & Média \\
\hline II & Alta & II & Média & Alta \\
\hline II & Alta & II & Alta & Alta \\
\hline
\end{tabular}

No sub-gupo do segundo nível que aborda dos PSFs Conhecimento de Padrões de Desempenho, Experiência, Nível de cultura de segurança, e Nível de cultura organizacional também engloba os PSFs Nível de práticas e Qualidade do Treinamento. Porém, estes dois últimos são indiferentes para a Informação.

\begin{tabular}{|c|c|c|c|c|}
\hline $\begin{array}{c}\text { Conhecimento de Padrões } \\
\text { de Desempenho } \\
\text { Experiência }\end{array}$ & Baixa & $\begin{array}{c}\text { Nível de cultura de } \\
\text { segurança } \\
\text { Nível de cultura } \\
\text { organizacional }\end{array}$ & Baixa & Baixa \\
\hline II & Baixa & II & Média & Baixa \\
\hline II & Baixa & II & Alta & M édia \\
\hline II & Média & II & Baixa & M édia \\
\hline II & Média & II & Média & M édia \\
\hline II & Média & II & Alta & Alta \\
\hline II & Alta & II & Baixa & M édia \\
\hline II & Alta & II & Média & Alta \\
\hline II & Alta & II & Alta & Alta \\
\hline
\end{tabular}




\subsubsection{3.}

\section{SIFs Hierárquicos do Terceiro Nível}

Conforme explicado anteriormente, os SIFs desse nível recebem as saídas do SIF anterior como variável de entrada e calcula a possibilidade de erro parcial para a Informação referente aos PSFs agrupados até este ponto.

\begin{tabular}{|c|c|c|c|c|}
\hline $\begin{array}{c}\text { Se possibilidade de erro } \\
\text { de Informação do Sub- } \\
\text { grupo }\end{array}$ & é & $\begin{array}{l}\text { e possibilidade de erro de } \\
\text { Informação do Sub-grupo }\end{array}$ & é & $\begin{array}{c}\text { Então } \\
\text { possibilidade } \\
\text { de erro de } \\
\text { Informação } \\
\text { é }\end{array}$ \\
\hline $\begin{array}{l}\text { Ameaças (de Falha, de } \\
\text { Perda do Emprego, etc.) } \\
\text { Falta de Recompensas, } \\
\text { Reconhecimento e } \\
\text { Benefícios } \\
\text { Motivos Conflitantes } \\
\text { sobre o Desempenho no } \\
\text { Trabalho } \\
\text { Carga Pesada de } \\
\text { Informações } \\
\text { Início Inesperado do } \\
\text { Stress }\end{array}$ & Baixa & $\begin{array}{l}\text { Ações desenvolvidas por } \\
\text { Supervisores, Colegas, } \\
\text { Representantes de } \\
\text { Sindicatos, e Pessoal de } \\
\text { Regulamentação } \\
\text { Comunicação } \\
\text { Estrutura de Equipe } \\
\text { Estrutura Organizacional }\end{array}$ & Baixa & Baixa \\
\hline II & Baixa & II & Média & Média \\
\hline II & Baixa & II & Alta & Alta \\
\hline II & Média & II & Baixa & Média \\
\hline II & Média & II & Média & Média \\
\hline II & Média & II & Alta & Alta \\
\hline II & Alta & II & Baixa & Média \\
\hline II & Alta & II & Média & Alta \\
\hline II & Alta & II & Alta & Alta \\
\hline
\end{tabular}

Os PSFs Capacidade Analítica, Capacidade de Classificação, Capacidade de Antecipação, e Capacidade de Tomada de Decisões são indiferentes para esta etapa, fazendo com que o SIF atual só dependa do resultado do SIF do outro subgrupo. Por sua vez o sub-grupo que contém o PSF Memória é de suma importância para todas as etapas de uma tarefa, uma vez que é representativo da característica "working memory", explicitamente avaliada como presente a todo instante no trabalho humano (Baddeley, 2003). 


\begin{tabular}{|c|c|c|c|c|}
\hline $\begin{array}{c}\text { Capacidade Analítica } \\
\text { Capacidade de Classificação } \\
\text { Capacidade de Antecipação } \\
\text { Capacidade de Tomada de } \\
\text { Decisões }\end{array}$ & Ind. & $\begin{array}{l}\text { Inteligência numérica } \\
\text { (capacidade de cálculos) } \\
\text { Percepção de séries } \\
\text { Memória } \\
\text { Predisposição para novos } \\
\text { conhecimentos }\end{array}$ & Baixa & Baixa \\
\hline II & Ind. & II & Média & Média \\
\hline II & Ind. & II & Alta & Alta \\
\hline
\end{tabular}

O SIF abaixo, composto pelos PSFs Cuidados e Advertências, Fatores de Interface de Hardware, Métodos de Trabalho, Políticas da Planta, Feedback (Conhecimento de Resultados), Procedimentos (Escritos ou Não Escritos), e Qualidade do Ambiente, também possui os PSFs Disponibilidade de Equipamentos Especiais, Instrumentos, e Insumos. Contudo estes três últimos não exercem influência direta na etapa em questão.

O PSF Qualidade do Ambiente é tratado aqui como um sub-grupo inteiro; ele não havia sido relacionado em outro SIF até então. Por isso, vale lembrar que, para o sub-grupo da Qualidade do Ambiente estar indicando possibilidade de erro de informação Baixa, é porque a Qualidade do Ambiente está Alta, ou seja, boa. Não confundir o conteúdo dessas regras com o "comportamento do PSF no empregado". Elas indicam apenas como possibilidades parciais de erros provenientes dos SIFs anteriores influenciam umas nas outras, de modo a comporem a possibilidade de erro do SIF atual.

\begin{tabular}{|c|c|c|c|c|}
\hline $\begin{array}{c}\text { Cuidados e Advertências } \\
\text { Fatores de Interface de } \\
\text { Hardware } \\
\text { M étodos de Trabalho } \\
\text { Políticas da Planta } \\
\text { Feedback (Conhecimento } \\
\text { de Resultados) } \\
\text { Procedimentos (Escritos ou } \\
\text { Não Escritos) }\end{array}$ & Baixa & Qualidade do Ambiente & Baixa & Baixa \\
\hline II & Baixa & Qualidade do Ambiente & Média & Baixa \\
\hline II & Baixa & Qualidade do Ambiente & Alta & Média \\
\hline II & Média & Qualidade do Ambiente & Baixa & Baixa \\
\hline II & Média & Qualidade do Ambiente & Média & Média \\
\hline II & Média & Qualidade do Ambiente & Alta & Alta \\
\hline II & Alta & Qualidade do Ambiente & Baixa & Alta \\
\hline II & Alta & Qualidade do Ambiente & Média & Alta \\
\hline II & Alta & Qualidade do Ambiente & Alta & Alta \\
\hline
\end{tabular}


Os PSFs Exercício Físico, Fadiga, Fome ou Sede, Interrupção do Ritmo Circadiano são indiferentes para a Informação, assim como o Trabalho em Alturas, também abordado por este SIF. Desta forma, apenas o resultado relativo aos PSFs Distrações, e Perda de Sensibilidade são pertinentes para este SIF do terceiro nível. O mesmo é válido para outros SIFs cuja uma das entradas é indiferente.

\begin{tabular}{|c|c|c|c|c|}
\hline $\begin{array}{c}\text { Exercício Físico } \\
\text { Fadiga }\end{array}$ & Ind. & $\begin{array}{c}\text { Distrações (devido a Ruído, } \\
\text { Clarão, M ovimentos, etc.) }\end{array}$ & Baixa & Baixa \\
$\begin{array}{c}\text { Fome ou Sede } \\
\text { Interrupção do Ritmo } \\
\text { Circadiano }\end{array}$ & & Perda de Sensibilidade & & \\
\hline II & Ind. & II & Média & M édia \\
\hline II & Ind. & II & Alta & Alta \\
\hline
\end{tabular}

\begin{tabular}{|c|l|c|c|c|}
\hline $\begin{array}{c}\text { Capacidade Crítica da } \\
\text { Tarefa }\end{array}$ & Baixa & $\begin{array}{c}\text { Freqüência e Repetitividade } \\
\text { da Tarefa } \\
\text { Horas de Trabalho / } \\
\text { Intervalos de Trabalho } \\
\text { Quantidade de Pessoal } \\
\text { (Carga de Informações) } \\
\text { Rodízio de Turnos }\end{array}$ & Ind. & Baixa \\
\hline$\|$ & Média & $\|$ & Ind. & M édia \\
\hline$\|$ & Alta & II & Ind. & Alta \\
\hline
\end{tabular}

\begin{tabular}{|c|c|c|c|c|}
\hline Desempenho & Ind. & $\begin{array}{c}\text { Conhecimento de Padrões } \\
\text { de Desempenho } \\
\text { Experiência } \\
\text { Nível de cultura de } \\
\text { segurança } \\
\text { Nível de cultura } \\
\text { organizacional } \\
\text { Nível de práticas } \\
\text { Qualidade do Treinamento }\end{array}$ & Baixa & Baixa \\
Persistência & Ind. & Média & M édia \\
\hline II & Ind & II & Alta & Alta \\
\hline II & Ind. & & & \\
\hline
\end{tabular}




\begin{tabular}{|c|c|c|c|c|}
\hline $\begin{array}{c}\text { Condição Física/Saúde } \\
\text { Influência de outros } \\
\text { agentes externos (pessoas, } \\
\text { família) } \\
\begin{array}{c}\text { Motivação } \\
\text { Tensão Mental ou Física }\end{array}\end{array}$ & Baixa & Denegação & Ind. & Baixa \\
\hline II & Média & Denegação & Ind. & M édia \\
\hline II & Alta & Denegação & Ind. & Alta \\
\hline
\end{tabular}

O SIF abaixo, relaciona fatores de stress psicológicos com fatores de personalidade. A maneira como um grupo influencia o outro permite que observações interessantes sejam realizadas. Sugestões Inconsistentes, quando indicando alta possibilidade de erro, por si só deveria fazer o SIF seguinte resultar em um erro de informação de alta possibilidade. Porém, ao analisarmos a outra entrada deste SIF visualiza-se fatores de personalidade que, se presentes de maneira positiva no funcionário, podem amenizar o impacto negativo e garantir a transferência/assimilação de informação. Isto significa que: se o funcionário for leal, simpático, e não for agressivo, ainda que esteja envolto por situações de reforço negativo, entediantes e com sugestões inconsistentes será capaz de superálas, pois sua personalidade não lhe deixa ser influenciado por tais fatores.

Similar a observação anterior, o extremo oposto também é factível. Supondo-se que um funcionário seja passível de ser facilmente alterado pelas situações de contexto negativo, caso estes não estejam ocorrendo, a informação será transmitida sem problemas. Isto ocorrerá pelo fato de que os demais PSFs (os do Grupo de Fatores de Stress Psicológicos) estarem sendo bem desempenhados (embora o funcionário em questão não seja o responsável por isso, e sim os demais). Em outras palavras, ainda que a pessoa seja abruptamente influenciável por situações negativas, o erro só ocorrerá se estas se manifestarem. 


\begin{tabular}{|c|c|c|c|c|}
\hline $\begin{array}{l}\text { Afiliação } \\
\text { Agressão } \\
\text { Autonomia }\end{array}$ & Baixa & $\begin{array}{l}\text { Períodos de Vigilância } \\
\text { Longos, sem } \\
\text { Acontecimentos } \\
\text { Trabalho M onótono, } \\
\text { Degradante ou Sem } \\
\text { Sentido } \\
\text { Reforço Negativo } \\
\text { Sugestões Inconsistentes }\end{array}$ & Baixa & Baixa \\
\hline II & Baixa & \| & Média & Baixa \\
\hline II & Baixa & II & Alta & Média \\
\hline II & Média & II & Baixa & Baixa \\
\hline II & Média & II & Média & Média \\
\hline II & Média & II & Alta & Alta \\
\hline II & Alta & II & Baixa & Média \\
\hline II & Alta & II & Média & Alta \\
\hline II & Alta & II & Alta & Alta \\
\hline
\end{tabular}

\subsubsection{4.}

\section{SIFs Hierárquicos do Quarto Nível}

Como em alguns SIFs anteriores, um dos sub-grupos é indiferente para a Informação.

\begin{tabular}{|c|c|c|c|c|}
\hline $\begin{array}{c}\text { Se possibilidade de erro } \\
\text { de Informação do Sub- } \\
\text { grupo }\end{array}$ & é & $\begin{array}{l}\text { e possibilidade de erro de } \\
\text { Informação do Sub-grupo }\end{array}$ & é & $\begin{array}{c}\text { Então } \\
\text { possibilidade } \\
\text { de erro de } \\
\text { Informação } \\
\text { é }\end{array}$ \\
\hline $\begin{array}{l}\text { Constrição de M ovimentos } \\
\text { Dor ou Desconforto }\end{array}$ & & $\begin{array}{c}\text { Capacidade Crítica da } \\
\text { Tarefa } \\
\text { Complexidade da Tarefa } \\
\text { (Carga de Informações) }\end{array}$ & & \\
\hline $\begin{array}{l}\text { Longa Duração do Stress } \\
\text { Repetição de M ovimentos }\end{array}$ & Ind. & $\begin{array}{c}\text { Freqüência e } \\
\text { Repetitividade da Tarefa } \\
\text { Horas de Trabalho / } \\
\text { Intervalos de Trabalho }\end{array}$ & Baixa & Baixa \\
\hline $\begin{array}{l}\text { Alta Velocidade na } \\
\text { Execução da Tarefa }\end{array}$ & & $\begin{array}{c}\text { Quantidade de Pessoal } \\
\text { Rodízio de Turnos }\end{array}$ & & \\
\hline Constrição de M ovimentos & Ind. & $\begin{array}{c}\text { Capacidade Crítica da } \\
\text { Tarefa }\end{array}$ & Média & Média \\
\hline Constrição de M ovimentos & Ind. & $\begin{array}{c}\text { Capacidade Crítica da } \\
\text { Tarefa }\end{array}$ & Alta & Alta \\
\hline
\end{tabular}


O SIF a seguir engloba três sub-grupos, isto é, três variáveis de entrada, a saber:

\begin{tabular}{|c|c|c|}
\hline $\begin{array}{l}\text { Ameaças (de Falha, de } \\
\text { Perda do Emprego, etc.) }\end{array}$ & \multirow{10}{*}{ Identificação com grupos } & Afago \\
\hline $\begin{array}{c}\text { Falta de Recompensas, } \\
\text { Reconhecimento e } \\
\text { Benefícios }\end{array}$ & & Afiliação \\
\hline $\begin{array}{l}\text { Motivos Conflitantes sobre } \\
\text { o Desempenho no Trabalho }\end{array}$ & & Agressão \\
\hline $\begin{array}{l}\text { Carga Pesada de } \\
\text { Informações }\end{array}$ & & Autonomia \\
\hline Início Inesperado do Stress & & \\
\hline $\begin{array}{l}\text { Supervisores, Colegas, } \\
\text { Representantes de }\end{array}$ & & $\begin{array}{l}\text { Períodos de Vigilância } \\
\text { Longos, sem }\end{array}$ \\
\hline $\begin{array}{l}\text { Sindicatos, e Pessoal de } \\
\text { Regulamentação }\end{array}$ & & Acontecimentos \\
\hline Comunicação & & $\begin{array}{l}\text { Trabalho M onótono, } \\
\text { Degradante ou Sem Sentido }\end{array}$ \\
\hline Estrutura de Equipe & & Reforço Negativo \\
\hline Estrutura Organizacional & & Sugestões Inconsistentes \\
\hline
\end{tabular}

Para mais bem exibir o comportamento da influência de um sobre os outros, suas regras foram divididas em três seções.

Um caso interessante mostrado na primeira seção é quando o primeiro subgrupo indica Baixa, o segundo indica Alta, e o terceiro indica Baixa possibilidade de erro de informação. É representante da situação em que, embora a identificação com os grupos esteja ruim, a comunicação com os mesmos está boa o suficiente, assim como o nível de agressão do funcionário é/está baixo, dessa forma não há erros de informação iminentes, porém pode ser encarado com o um equilíbrio instável, uma pequena variação pode fazer a possibilidade de erro aumentar drasticamente.

Caso o sub-grupo dos PSFs Ameaças (de Falha, de Perda do Emprego, etc.); Falta de Recompensas, Reconhecimento e Benefícios; Motivos Conflitantes sobre o Desempenho no Trabalho; Carga Pesada de Informações; Início Inesperado do Stress; Ações desenvolvidas por Supervisores, Colegas, Representantes de Sindicatos, e Pessoal de Regulamentação; Comunicação; Estrutura de Equipe; e Estrutura Organizacional esteja indicando Baixa possibilidade de erro de informação: 


\begin{tabular}{|c|c|c|c|c|}
\hline $\begin{array}{c}\text { Se possibilidade de erro } \\
\text { de Informação do Sub- } \\
\text { grupo }\end{array}$ & é & $\begin{array}{l}\text { e possibilidade de erro de } \\
\text { Informação do Sub-grupo }\end{array}$ & é & $\begin{array}{c}\text { Então } \\
\text { possibilidade } \\
\text { de erro de } \\
\text { Informação } \\
\text { é }\end{array}$ \\
\hline Identificação com grupos & Baixa & $\begin{array}{c}\text { Afago } \\
\text { Afiliação } \\
\text { Agressão } \\
\text { Autonomia } \\
\text { Períodos de Vigilância } \\
\text { Longos, sem } \\
\text { Acontecimentos } \\
\text { Trabalho M onótono, } \\
\text { Degradante ou Sem } \\
\text { Sentido } \\
\text { Reforço Negativo } \\
\text { Sugestões Inconsistentes }\end{array}$ & Baixa & Baixa \\
\hline Identificação com grupos & Baixa & II & Média & Baixa \\
\hline Identificação com grupos & Baixa & II & Alta & Média \\
\hline Identificação com grupos & Média & II & Baixa & Baixa \\
\hline Identificação com grupos & Média & II & Média & Média \\
\hline Identificação com grupos & Média & II & Alta & Média \\
\hline Identificação com grupos & Alta & II & Baixa & Baixa \\
\hline Identificação com grupos & Alta & II & Média & Média \\
\hline Identificação com grupos & Alta & II & Alta & Alta \\
\hline
\end{tabular}

Caso o primeiro sub-grupo esteja indicando Média:

\begin{tabular}{|l|l|l|c|c|}
\hline Identificação com grupos & Baixa & II & Baixa & Baixa \\
\hline Identificação com grupos & Baixa & II & Média & M édia \\
\hline Identificação com grupos & Baixa & II & Alta & M édia \\
\hline Identificação com grupos & Média & II & Baixa & M édia \\
\hline Identificação com grupos & Média & II & Média & M édia \\
\hline Identificação com grupos & Média & II & Alta & Alta \\
\hline Identificação com grupos & Alta & II & Baixa & M édia \\
\hline Identificação com grupos & Alta & II & Média & Alta \\
\hline Identificação com grupos & Alta & II & Alta & Alta \\
\hline
\end{tabular}


E caso o primeiro sub-grupo esteja indicando Alta:

\begin{tabular}{|l|c|c|c|c|}
\hline Identificação com grupos & Baixa & II & Baixa & M édia \\
\hline Identificação com grupos & Baixa & II & Média & M édia \\
\hline Identificação com grupos & Baixa & II & Alta & Alta \\
\hline Identificação com grupos & Média & II & Baixa & Média \\
\hline Identificação com grupos & Média & II & Média & Alta \\
\hline Identificação com grupos & Média & II & Alta & Alta \\
\hline Identificação com grupos & Alta & II & Baixa & Alta \\
\hline Identificação com grupos & Alta & II & Média & Alta \\
\hline Identificação com grupos & Alta & II & Alta & Alta \\
\hline
\end{tabular}

O SIF que contém o PSF Métodos de Trabalho também contém outros PSFs que influenciam a Informação de maneira mais direta, sendo por sua vez o que terá mais impacto neste SIF de quarto nível.

\begin{tabular}{|c|c|c|c|c|}
\hline $\begin{array}{l}\text { Cuidados e Advertências } \\
\text { Fatores de Interface de } \\
\text { Hardware } \\
\text { M étodos de Trabalho } \\
\text { Políticas da Planta } \\
\text { Feedback (Conhecimento } \\
\text { de Resultados) } \\
\text { Procedimentos (Escritos ou } \\
\text { Não Escritos) } \\
\text { Qualidade do Ambiente }\end{array}$ & Baixa & $\begin{array}{c}\text { Desempenho } \\
\text { Dominância } \\
\text { Ordem } \\
\text { Persistência } \\
\text { Conhecimento de Padrões } \\
\text { de Desempenho } \\
\text { Experiência } \\
\text { Nível de cultura de } \\
\text { segurança } \\
\text { Nível de cultura } \\
\text { organizacional } \\
\text { Nível de práticas } \\
\text { Qualidade do Treinamento }\end{array}$ & Baixa & Baixa \\
\hline II & Baixa & II & Média & Baixa \\
\hline II & Baixa & II & Alta & M édia \\
\hline II & Média & II & Baixa & Média \\
\hline II & Média & II & Média & Média \\
\hline II & Média & II & Alta & Média \\
\hline II & Alta & II & Baixa & M édia \\
\hline II & Alta & II & Média & Alta \\
\hline II & Alta & II & Alta & Alta \\
\hline
\end{tabular}

O sub-grupo da primeira coluna do SIF abaixo tem apenas dois PSFs nãoindiferentes para a Informação. Contudo, o PSF Distrações está presente lá, que é uma das maneiras de se manifestar os PSFs presentes no outro sub-grupo. Portanto se Distrações está indicando Baixa possibilidade de erro, mesmo que Motivação ou Tensão Mental esteja indicando Alta, a informação ainda pode ser 
passada corretamente, uma vez que o colaborador não perdeu sua concentração. Segundo (Hendrick, 2010) "situation awareness" é explicitamente um quesito de influencia diretamente a Informação, e se Distrações está bem desempenhado, o funcionário está consciente da situação a qual está inserido.

\begin{tabular}{|c|c|c|c|c|}
\hline $\begin{array}{c}\text { Exercício Físico } \\
\text { Fadiga } \\
\text { Fome ou Sede } \\
\text { Interrupção do Ritmo } \\
\text { Circadiano } \\
\text { Distrações (devido a } \\
\text { Ruído, Clarão, } \\
\text { Movimentos, etc.) } \\
\text { Perda de Sensibilidade } \\
\text { Trabalho em Alturas }\end{array}$ & Baixa & $\begin{array}{c}\text { Condição Física/Saúde } \\
\text { Influência de outros agentes } \\
\text { externos (pessoas, família) } \\
\text { M otivação } \\
\text { Tensão M ental ou Física } \\
\text { Denegação }\end{array}$ & Baixa & Baixa \\
\hline II & Baixa & II & Média & Média \\
\hline II & Baixa & II & Alta & Média \\
\hline II & Média & II & Baixa & Baixa \\
\hline II & Média & II & Média & Média \\
\hline II & Média & II & Alta & Alta \\
\hline II & Alta & II & Baixa & Média \\
\hline II & Alta & II & Média & Alta \\
\hline II & Alta & II & Alta & Alta \\
\hline
\end{tabular}

\subsubsection{5.}

\section{SIFs Hierárquicos do Quinto Nível}

No sub-grupo da primeira coluna apenas os PSFs Capacidade Crítica da Tarefa e Complexidade da Tarefa influenciam a Informação, contudo tais PSFs são críticos para esta etapa, fazendo com que sua importância seja significativa para o SIF de quinto nível que o contém. 


\begin{tabular}{|c|c|c|c|c|}
\hline $\begin{array}{c}\text { Se possibilidade de erro } \\
\text { de Informação do Sub- } \\
\text { grupo }\end{array}$ & é & $\begin{array}{l}\text { e possibilidade de erro de } \\
\text { Informação do Sub-grupo }\end{array}$ & é & $\begin{array}{c}\text { Então } \\
\text { possibilidade } \\
\text { de erro de } \\
\text { Informação } \\
\text { é }\end{array}$ \\
\hline $\begin{array}{c}\text { Constrição de } \\
\text { M ovimentos } \\
\text { Dor ou Desconforto } \\
\text { Longa Duração do } \\
\text { Stress } \\
\text { Repetição de } \\
\text { M ovimentos } \\
\text { Alta Velocidade na } \\
\text { Execução da Tarefa } \\
\text { Capacidade Crítica da } \\
\text { Tarefa } \\
\text { Complexidade da Tarefa } \\
\text { (Carga de Informações) } \\
\text { Freqüência e } \\
\text { Repetitividade da } \\
\text { Tarefa } \\
\text { Horas de Trabalho / } \\
\text { Intervalos de Trabalho } \\
\text { Quantidade de Pessoal } \\
\text { Rodízio de Turnos }\end{array}$ & Baixa & $\begin{array}{c}\text { Exercício Físico } \\
\text { Fadiga } \\
\text { Fome ou Sede } \\
\text { Interrupção do Ritmo } \\
\text { Circadiano } \\
\text { Distrações (devido a Ruído, } \\
\text { Clarão, M ovimentos, etc.) } \\
\text { Perda de Sensibilidade } \\
\text { Trabalho em Alturas } \\
\text { Condição Física/Saúde } \\
\text { Influência de outros agentes } \\
\text { externos (pessoas, família) } \\
\text { M otivação } \\
\text { Tensão M ental ou Física } \\
\text { Denegação }\end{array}$ & Baixa & Baixa \\
\hline II & Baixa & II & Média & Baixa \\
\hline II & Baixa & II & Alta & Média \\
\hline II & Média & II & Baixa & Baixa \\
\hline II & Média & II & Média & Média \\
\hline II & Média & II & Alta & Alta \\
\hline II & Alta & II & Baixa & Média \\
\hline II & Alta & II & Média & Alta \\
\hline II & Alta & II & Alta & Alta \\
\hline
\end{tabular}

Continuidade de Matrizes ou Conjuntos, bem como Estruturação do Campo Perceptivo são indiferentes para a obtenção de informação. 


\begin{tabular}{|c|c|c|c|c|}
\hline $\begin{array}{c}\text { Cuidados e Advertências } \\
\text { Fatores de Interface de } \\
\text { Hardware } \\
\text { Métodos de Trabalho } \\
\text { Políticas da Planta } \\
\text { Feedback (Conhecimento } \\
\text { de Resultados) } \\
\text { Procedimentos (Escritos ou } \\
\text { Não Escritos) } \\
\text { Qualidade do Ambiente } \\
\text { Desempenho } \\
\text { Dominância } \\
\text { Ordem } \\
\text { Persistência } \\
\text { Conhecimento de Padrões } \\
\text { de Desempenho } \\
\text { Experiência } \\
\text { Nível de cultura de } \\
\text { segurança } \\
\text { Nível de cultura } \\
\text { organizacional } \\
\text { Nível de práticas } \\
\text { Qualidade do Treinamento }\end{array}$ & Baixa & $\begin{array}{c}\text { Continuidade de M atrizes } \\
\text { ou Conjuntos }\end{array}$ & Ind. & Baixa \\
\hline II & Média & II & Ind. & Média \\
\hline II & Alta & II & Ind. & Alta \\
\hline
\end{tabular}


Os PSFs Assistência, Deferência, Exibição, Intracepção, e Mudança são indiferentes para a obtenção da informação.

\begin{tabular}{|c|c|c|c|c|}
\hline $\begin{array}{l}\text { Ameaças (de Falha, de } \\
\text { Perda do Emprego, etc.) } \\
\text { Falta de Recompensas, } \\
\text { Reconhecimento e } \\
\text { Benefícios } \\
\text { M otivos Conflitantes sobre } \\
\text { o Desempenho no Trabalho } \\
\text { Carga Pesada de } \\
\text { Informações } \\
\text { Início Inesperado do Stress } \\
\text { Ações desenvolvidas por } \\
\text { Supervisores, Colegas, } \\
\text { Representantes de } \\
\text { Sindicatos, e Pessoal de } \\
\text { Regulamentação } \\
\text { Comunicação } \\
\text { Estrutura de Equipe } \\
\text { Estrutura Organizacional } \\
\text { Identificação com grupos } \\
\text { Afago } \\
\text { Afiliação } \\
\text { Agressão } \\
\text { Autonomia } \\
\text { Períodos de Vigilância } \\
\text { Longos, sem } \\
\text { Acontecimentos } \\
\text { Trabalho M onótono, } \\
\text { Degradante ou Sem Sentido } \\
\text { Reforço Negativo } \\
\text { Sugestões Inconsistentes } \\
\end{array}$ & Baixa & $\begin{array}{l}\text { Exibição } \\
\text { Intracepção }\end{array}$ & Ind. & Baixa \\
\hline II & Média & II & Ind. & Média \\
\hline II & Alta & II & Ind. & Alta \\
\hline
\end{tabular}




\subsubsection{6.}

\section{SIF Hierárquico do Sexto Nível}

Novamente, apesar de uma das variáveis de entrada do SIF possuírem maior quantidade de PSFs que influenciam diretamente a Informação, o nível de importância das variáveis presentes no outro sub-grupo fazem com que ambos tenham grande participação na saída deste SIF de sexto nível.

\begin{tabular}{|c|c|c|c|c|}
\hline $\begin{array}{l}\text { Se possibilidade de erro de } \\
\text { Informação do Sub-grupo }\end{array}$ & é & $\begin{array}{c}\text { e possibilidade de erro } \\
\text { de Informação do Sub- } \\
\text { grupo }\end{array}$ & é & $\begin{array}{c}\text { Então } \\
\text { possibilidade } \\
\text { de erro de } \\
\text { Informação } \\
\text { é }\end{array}$ \\
\hline $\begin{array}{l}\text { Cuidados e Advertências / } \\
\text { Fatores de Interface / } \\
\text { Métodos de Trabalho / } \\
\text { Políticas da Planta / } \\
\text { Feedback (conhecimentos } \\
\text { de resultados) / } \\
\text { Procedimentos (Escritos ou } \\
\text { Não Escritos) / Qualidade } \\
\text { do Ambiente / } \\
\text { Desempenho / Dominância } \\
\text { / Ordem / Persistência / } \\
\text { Conhecimento de Padrões } \\
\text { de Desempenho / } \\
\text { Experiência / Cultura de } \\
\text { Segurança / Cultura } \\
\text { Organizacional / Nível de } \\
\text { Práticas / Qualidade do } \\
\text { Treinamento / } \\
\text { Continuidade de M atrizes } \\
\text { ou Conjuntos / } \\
\text { Estruturação do Campo } \\
\text { Perceptivo (topologia) }\end{array}$ & Baixa & $\begin{array}{l}\text { Capacidade Analítica } \\
\text { Capacidade de } \\
\text { Classificação } \\
\text { Capacidade de } \\
\text { Antecipação } \\
\text { Capacidade de Tomada } \\
\text { de Decisões } \\
\text { Inteligência numérica } \\
\text { (capacidade de cálculos) } \\
\text { Percepção de séries } \\
\text { M emória } \\
\text { Predisposição para } \\
\text { novos conhecimentos }\end{array}$ & Baixa & Baixa \\
\hline II & Baixa & II & Média & Baixa \\
\hline II & Baixa & II & Alta & Média \\
\hline II & Média & II & Baixa & Baixa \\
\hline 11 & Média & II & Média & Média \\
\hline II & Média & II & Alta & Alta \\
\hline II & Alta & II & Baixa & Média \\
\hline II & Alta & II & Média & Alta \\
\hline II & Alta & II & Alta & Alta \\
\hline
\end{tabular}




\subsubsection{7. \\ SIF Hierárquico do Sétimo Nível}

O sub-grupo composto pelo PSF Ameaças e os demais tem maior impacto na Informação do que o outro sub-grupo, dessa forma, sua influência nas regras deste SIF também é maior.

\begin{tabular}{|c|c|c|c|c|}
\hline $\begin{array}{c}\text { Se possibilidade de erro } \\
\text { de Informação do Sub- } \\
\text { grupo }\end{array}$ & é & $\begin{array}{l}\text { e possibilidade de erro de } \\
\text { Informação do Sub-grupo }\end{array}$ & é & $\begin{array}{c}\text { Então } \\
\text { possibilidade } \\
\text { de erro de } \\
\text { Informação } \\
\text { é }\end{array}$ \\
\hline $\begin{array}{c}\text { Cuidados / Fatores de } \\
\text { Interface / Métodos de } \\
\text { Trabalho / Políticas da } \\
\text { Planta / Feedback / } \\
\text { Procedimentos / } \\
\text { Qualidade do Ambiente / } \\
\text { Desempenho / } \\
\text { Dominância / Ordem / } \\
\text { Persistência / } \\
\text { Conhecimento de Padrões } \\
\text { / Experiência / Cultura de } \\
\text { Segurança / Cultura } \\
\text { Organizacional / Práticas / } \\
\text { Qualidade do } \\
\text { Treinamento / } \\
\text { Continuidade de M atrizes } \\
\text { ou Conjuntos / } \\
\text { Estruturação do Campo } \\
\text { Perceptivo (topologia) / } \\
\text { Capacidade Analítica / } \\
\text { Capacidade de } \\
\text { Classificação / Capacidade } \\
\text { de Antecipação / } \\
\text { Capacidade de Tomada de } \\
\text { Decisões / Inteligência } \\
\text { numérica / Percepção de } \\
\text { séries / M emória / } \\
\text { Predisposição para Novos } \\
\text { Conhecimentos }\end{array}$ & Baixa & $\begin{array}{c}\text { Ameaças / Falta de } \\
\text { Reconhecimento / } \\
\text { M otivos Conflitantes / } \\
\text { Carga Pesada de } \\
\text { Informações / Início } \\
\text { Inesperado do Stress / } \\
\text { Ações desenvolvidas por } \\
\text { Supervisores / } \\
\text { Comunicação / Estrutura } \\
\text { de Equipe Estrutura } \\
\text { Organizacional / } \\
\text { Identificação com grupos / } \\
\text { Afago / Afiliação / } \\
\text { Agressão / Autonomia / } \\
\text { Períodos sem } \\
\text { Acontecimentos / } \\
\text { Trabalho M onótono / } \\
\text { Reforço Negativo / } \\
\text { Sugestões Inconsistentes / } \\
\text { Assistência / Deferência / } \\
\text { Exibição / Intracepção / } \\
\text { M udança }\end{array}$ & Baixa & Baixa \\
\hline II & Baixa & II & Média & Média \\
\hline II & Baixa & II & Alta & Alta \\
\hline II & Média & II & Baixa & Baixa \\
\hline II & Média & II & Média & Média \\
\hline II & Média & II & Alta & Alta \\
\hline II & Alta & II & Baixa & Média \\
\hline II & Alta & II & Média & Alta \\
\hline II & Alta & II & Alta & Alta \\
\hline
\end{tabular}




\subsubsection{8.}

\section{SIF Hierárquico do Oitavo Nível}

O sub-grupo da primeira coluna do SIF abaixo possui uma grande quantidade de fatores que demoram mais tempo para alterar seu desempenho, ou que são fixos dado um intervalo de tempo. Como por exemplo, fatores de personalidade, fatores relativos à experiência e conhecimento. Diferem de fatores situacionais, que variam a curto prazo. O sub-grupo que contém o PSF Distrações (terceira coluna) é composto por PSFs de variação mais sensível a curto prazo/volatilidade.

\begin{tabular}{|c|c|c|c|c|}
\hline $\begin{array}{c}\text { Se possibilidade de erro } \\
\text { de Informação do Sub- } \\
\text { grupo }\end{array}$ & é & $\begin{array}{c}\text { e possibilidade de erro } \\
\text { de Informação do Sub- } \\
\text { grupo }\end{array}$ & é & $\begin{array}{c}\text { Então } \\
\text { possibilidade } \\
\text { de erro de } \\
\text { Informação } \\
\text { é }\end{array}$ \\
\hline $\begin{array}{c}\text { Cuidados / Fatores de } \\
\text { Interface / M étodos de } \\
\text { Trabalho / Políticas da } \\
\text { Planta / Feedback / } \\
\text { Procedimentos / } \\
\text { Qualidade do Ambiente / } \\
\text { Desempenho / } \\
\text { Dominância / Ordem / } \\
\text { Persistência / } \\
\text { Conhecimento de Padrões } \\
\text { / Experiência / Cultura de } \\
\text { Segurança / Cultura } \\
\text { Organizacional / Práticas / } \\
\text { Qualidade do } \\
\text { Treinamento / } \\
\text { Continuidade de Matrizes } \\
\text { ou Conjuntos / } \\
\text { Estruturação do Campo } \\
\text { Perceptivo (topologia) / } \\
\text { Capacidade Analítica / } \\
\text { Capacidade de } \\
\text { Classificação / Capacidade } \\
\text { de Antecipação / } \\
\text { Capacidade de Tomada de } \\
\text { Decisões / Inteligência } \\
\text { numérica / Percepção de } \\
\text { Séries / M emória / } \\
\text { Predisposição para Novos } \\
\text { Conhecimentos / Ameaças } \\
\text { / Falta de } \\
\text { Reconhecimento / } \\
\text { Motivos Conflitantes / }\end{array}$ & Baixa & $\begin{array}{c}\text { Constrição de } \\
\text { Movimentos / Dor ou } \\
\text { Desconforto / Longa } \\
\text { duração do Stress / } \\
\text { Repetição de M ov. / Alta } \\
\text { Velocidade na Execução / } \\
\text { Capacidade Crítica / } \\
\text { Complexidade / } \\
\text { Repetitividade / } \\
\text { Intervalos / Quantidade } \\
\text { de Pessoal / Turnos / } \\
\text { Exercício Físico / Fadiga / } \\
\text { Fome ou Sede / Int. Ritmo } \\
\text { Circ. / Distrações / Perda } \\
\text { de Sensibilidade / } \\
\text { Trabalho em Alturas / } \\
\text { Condição Física/ Saúde / } \\
\text { Agentes externos / } \\
\text { M otivaçãoo / Tensão } \\
\text { M ental ou Física / } \\
\text { Denegação }\end{array}$ & Baixa & Baixa \\
\hline
\end{tabular}




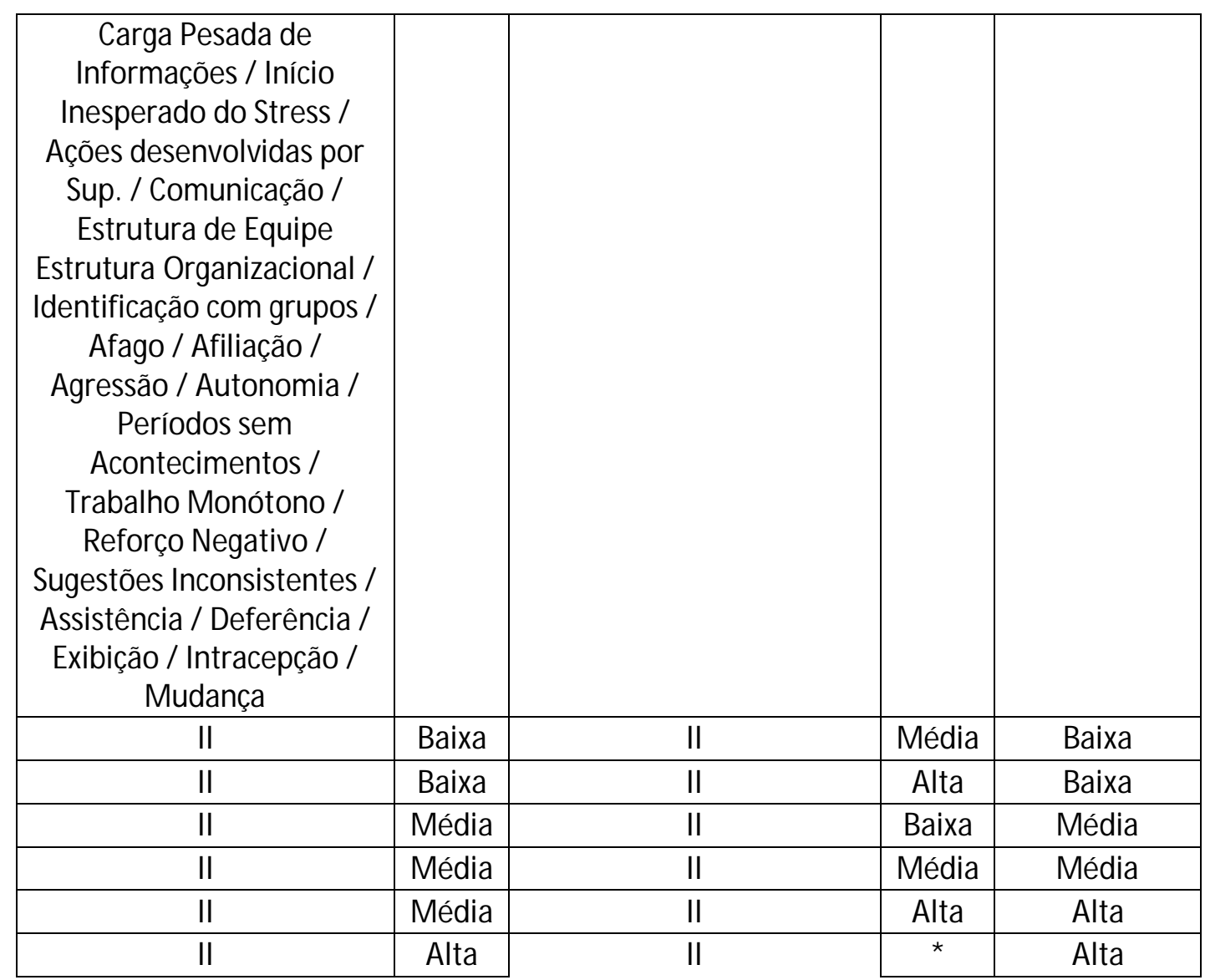

\subsubsection{9. \\ SIF Hierárquico do Nono Nível}

O PSF Nível de Atenção como mostrado na Figura 9 é uma das entradas do SIF final, no qual a outra é entrada é a saída do SIF Hierárquico do Oitavo Nível. De fato, o PSF Nível de Atenção é o de maior importância para qualquer etapa relativa ao desempenho humano em uma tarefa, por isso se junta neste SIF final. A atenção, se indicativa de uma alta possibilidade de falha, poderá por si só ser responsável por um erro humano, ainda que os demais PSFs estejam sendo bem desempenhados. Um funcionário não será capaz de lembrar (PSF Memória) do que foi lhe passado se estava com grande déficit de atenção no momento em que suas obrigações lhe foram transmitidas - não é possível lembrar de algo que não foi assimilado; da mesma forma como sua experiência e conhecimentos são capazes apenas de garantir a expectativa do que lhe será informado, mas não realmente captar e absorver a informação. Naturalmente, se os principais PSFs 
pertinentes à Informação estiverem com excelente desempenho, a falta de atenção poderá ter seu impacto amenizado, mas não eliminado.

\begin{tabular}{|c|c|c|c|c|}
\hline Demais PSFs & Baixa & Nível de Atenção & Baixa & Baixa \\
\hline Demais PSFs & Baixa & Nível de Atenção & Média & M édia \\
\hline Demais PSFs & Baixa & Nível de Atenção & Alta & M édia \\
\hline Demais PSFs & M édia & Nível de Atenção & Baixa & M édia \\
\hline Demais PSFs & M édia & Nível de Atenção & Média & M édia \\
\hline Demais PSFs & M édia & Nível de Atenção & Alta & Alta \\
\hline Demais PSFs & Alta & Nível de Atenção & $*$ & Alta \\
\hline
\end{tabular}

\subsection{2.}

\section{Etapa Decisão}

A etapa de Decisão é interna ao funcionário, e faz uso das suas lembranças, conhecimentos e experiências para planejar como irá agir a respeito da informação coletada na etapa anterior. É quando o colaborador se imagina realizando a tarefa, isto é, como ele a modela antes de executá-la propriamente.

Uma consideração feita aqui é que a informação recebida na etapa anterior estava correta, e sua assimilação ocorreu sem erros. Caso essa premissa não seja verdadeira, não há problema no que diz respeito aos cálculos de possibilidade de erro desta tarefa, mas é importante ressaltar que são considerados apenas erros de Decisão, enquanto erros de Informação foram calculados na etapa anterior isoladamente. Naturalmente, uma tarefa pode conter simultaneamente erros em múltiplas etapas, neste caso, o sistema desenvolvido neste trabalho apontará a possibilidade de erro da tarefa em cada fase de sua realização separadamente.

Durante esta etapa, a maioria dos PSFs do Grupo de PSFs Fatores de Stress Fisiológicos não exercem influência direta. Os PSFs desse grupo que são considerados como indiferentes são: Constrição de Movimentos, Dor ou Desconforto, Exercício Físico, Fadiga, Longa Duração do Stress, Repetição de Movimentos, e Trabalho em Alturas. Apenas os fatores Fome ou Sede, e Interrupção do Ritmo Circadiano são capazes de afetar negativa e diretamente o desempenho humano na etapa de Decisão.

Analogamente, os PSFs Cuidados e Advertências, Fatores de Interface de Hardware, Quantidade de Pessoal, e Rodízio de Turnos pertencentes ao Grupo de PSFs Fatores Externos também não influenciam diretamente a Decisão pois são fatores que se manifestam apenas durante a execução da tarefa (etapa Ação). 
As regras para o tipo de erro Decisão são exibidas a seguir.

\subsubsection{1.}

\section{SIFs Hierárquicos do Primeiro Nível}

Os PSFs presentes nestes dois primeiros SIFs apesar de não serem importantes na etapa anterior, aqui são imprescindíveis para o sucesso da tarefa. Capacidade Analítica, Capacidade de Classificação, Capacidade de Antecipação e Capacidade de Tomada de Decisões são fatores cruciais no momento do planejamento e simulação mental do que se irá fazer na etapa seguinte.

\begin{tabular}{|c|c|c|c|c|}
\hline Se & é & e & é & $\begin{array}{c}\text { Então } \\
\text { possibilidade } \\
\text { de erro de } \\
\text { Decisão é }\end{array}$ \\
\hline Capacidade Analítica & Baixa & $\begin{array}{l}\text { Capacidade de } \\
\text { Classificação }\end{array}$ & $*$ & Alta \\
\hline Capacidade Analítica & $*$ & $\begin{array}{l}\text { Capacidade de } \\
\text { Classificação }\end{array}$ & Baixa & Alta \\
\hline Capacidade Analítica & M édia & $\begin{array}{l}\text { Capacidade de } \\
\text { Classificação }\end{array}$ & Média & Média \\
\hline Capacidade Analítica & M édia & $\begin{array}{l}\text { Capacidade de } \\
\text { Classificação }\end{array}$ & Alta & Baixa \\
\hline Capacidade Analítica & Alta & $\begin{array}{l}\text { Capacidade de } \\
\text { Classificação }\end{array}$ & Média & Baixa \\
\hline Capacidade Analítica & Alta & $\begin{array}{l}\text { Capacidade de } \\
\text { Classificação }\end{array}$ & Alta & Baixa \\
\hline $\begin{array}{l}\text { Capacidade de } \\
\text { Antecipação }\end{array}$ & Baixa & $\begin{array}{c}\text { Capacidade de Tomada de } \\
\text { Decisões }\end{array}$ & Baixa & Alta \\
\hline $\begin{array}{l}\text { Capacidade de } \\
\text { Antecipação }\end{array}$ & Baixa & $\begin{array}{c}\text { Capacidade de Tomada de } \\
\text { Decisões }\end{array}$ & M édia & Média \\
\hline $\begin{array}{l}\text { Capacidade de } \\
\text { Antecipação }\end{array}$ & Baixa & $\begin{array}{c}\text { Capacidade de Tomada de } \\
\text { Decisões }\end{array}$ & Alta & Média \\
\hline $\begin{array}{l}\text { Capacidade de } \\
\text { Antecipação }\end{array}$ & Média & $\begin{array}{c}\text { Capacidade de Tomada de } \\
\text { Decisões }\end{array}$ & Baixa & Alta \\
\hline $\begin{array}{l}\text { Capacidade de } \\
\text { Antecipação }\end{array}$ & M édia & $\begin{array}{c}\text { Capacidade de Tomada de } \\
\text { Decisões }\end{array}$ & Média & Média \\
\hline $\begin{array}{l}\text { Capacidade de } \\
\text { Antecipação }\end{array}$ & M édia & $\begin{array}{c}\text { Capacidade de Tomada de } \\
\text { Decisões }\end{array}$ & Alta & Baixa \\
\hline $\begin{array}{l}\text { Capacidade de } \\
\text { Antecipação }\end{array}$ & Alta & $\begin{array}{c}\text { Capacidade de Tomada de } \\
\text { Decisões }\end{array}$ & Baixa & Alta \\
\hline $\begin{array}{l}\text { Capacidade de } \\
\text { Antecipação }\end{array}$ & Alta & $\begin{array}{c}\text { Capacidade de Tomada de } \\
\text { Decisões }\end{array}$ & Média & Baixa \\
\hline $\begin{array}{l}\text { Capacidade de } \\
\text { Antecipação }\end{array}$ & Alta & $\begin{array}{c}\text { Capacidade de Tomada de } \\
\text { Decisões }\end{array}$ & Alta & Baixa \\
\hline
\end{tabular}


O PSF Estruturação do Campo Perceptivo não é pertinente nesta etapa, contundo na etapa de Ação seu mal desempenho pode ser crítico. Continuidade de Matrizes ou Conjuntos reflete o quão bem o funcionário conhece/percebe seu ambiente de trabalho, o que influencia diretamente na maneira como irá decidir sobre como agir.

\begin{tabular}{|c|c|c|c|c|}
\hline $\begin{array}{c}\text { Continuidade de matrizes } \\
\text { ou conjuntos }\end{array}$ & Baixa & $\begin{array}{c}\text { Estruturação do campo } \\
\text { perceptivo (topologia) }\end{array}$ & Baixa & Alta \\
\hline $\begin{array}{c}\text { Continuidade de matrizes } \\
\text { ou conjuntos }\end{array}$ & Baixa & $\begin{array}{c}\text { Estruturação do campo } \\
\text { perceptivo (topologia) }\end{array}$ & M édia & Alta \\
\hline $\begin{array}{c}\text { Continuidade de matrizes } \\
\text { ou conjuntos }\end{array}$ & Baixa & $\begin{array}{c}\text { Estruturação do campo } \\
\text { perceptivo (topologia) }\end{array}$ & Alta & Alta \\
\hline $\begin{array}{c}\text { Continuidade de matrizes } \\
\text { ou conjuntos }\end{array}$ & Média & $\begin{array}{c}\text { Estruturação do campo } \\
\text { perceptivo (topologia) }\end{array}$ & Baixa & M édia \\
\hline $\begin{array}{c}\text { Continuidade de matrizes } \\
\text { ou conjuntos }\end{array}$ & Média & $\begin{array}{c}\text { Estruturação do campo } \\
\text { perceptivo (topologia) }\end{array}$ & Média & Média \\
\hline $\begin{array}{c}\text { Continuidade de matrizes } \\
\text { ou conjuntos }\end{array}$ & Média & $\begin{array}{c}\text { Estruturação do campo } \\
\text { perceptivo (topologia) }\end{array}$ & Alta & M édia \\
\hline $\begin{array}{c}\text { Continuidade de matrizes } \\
\text { ou conjuntos }\end{array}$ & Alta & $\begin{array}{c}\text { Estruturação do campo } \\
\text { perceptivo (topologia) }\end{array}$ & Baixa & Baixa \\
\hline $\begin{array}{c}\text { Continuidade de matrizes } \\
\text { ou conjuntos }\end{array}$ & Alta & $\begin{array}{c}\text { Estruturação do campo } \\
\text { perceptivo (topologia) }\end{array}$ & M édia & Baixa \\
\hline $\begin{array}{c}\text { Continuidade de matrizes } \\
\text { ou conjuntos }\end{array}$ & Alta & $\begin{array}{c}\text { Estruturação do campo } \\
\text { perceptivo (topologia) }\end{array}$ & Alta & Baixa \\
\hline
\end{tabular}

Os PSFs do SIF abaixo são indicadores da habilidade de raciocínio lógico do operador, com influência direta na Decisão.

\begin{tabular}{|c|c|c|c|c|}
\hline $\begin{array}{c}\text { Inteligência numérica } \\
\text { (capacidade de cálculos) }\end{array}$ & Baixa & Percepção de séries & Baixa & Alta \\
\hline $\begin{array}{c}\text { Inteligência numérica } \\
\text { (capacidade de cálculos) }\end{array}$ & Baixa & Percepção de séries & Média & Alta \\
\hline $\begin{array}{c}\text { Inteligência numérica } \\
\text { (capacidade de cálculos) }\end{array}$ & Baixa & Percepção de séries & Alta & M édia \\
\hline $\begin{array}{c}\text { Inteligência numérica } \\
\text { (capacidade de cálculos) }\end{array}$ & Média & Percepção de séries & Baixa & Alta \\
\hline $\begin{array}{c}\text { Inteligência numérica } \\
\text { (capacidade de cálculos) }\end{array}$ & Média & Percepção de séries & Média & Média \\
\hline $\begin{array}{c}\text { Inteligência numérica } \\
\text { (capacidade de cálculos) }\end{array}$ & Média & Percepção de séries & Alta & Baixa \\
\hline $\begin{array}{c}\text { Inteligência numérica } \\
\text { (capacidade de cálculos) }\end{array}$ & Alta & Percepção de séries & Baixa & Média \\
\hline $\begin{array}{c}\text { Inteligência numérica } \\
\text { (capacidade de cálculos) }\end{array}$ & Alta & Percepção de séries & Média & Baixa \\
\hline $\begin{array}{c}\text { Inteligência numérica } \\
\text { (capacidade de cálculos) }\end{array}$ & Alta & Percepção de séries & Alta & Baixa \\
\hline
\end{tabular}


Memória é um dos fatores mais importantes na etapa de Decisão. A incapacidade de lembrar do que lhe foi passado na etapa da Informação pode fazer com que um planejamento adequado seja impraticável. A Predisposição para Novos Conhecimentos também constitui um fator de influência direta, pois representa a capacidade do funcionário de se desvencilhar de vícios de trabalho, provenientes de experiências anteriores, quando diante de uma situação nova, ainda que com aspectos similares a outras já conhecidas.

\begin{tabular}{|c|c|c|c|c|}
\hline Memória & Baixa & $\begin{array}{c}\text { Predisposição para novos } \\
\text { conhecimentos }\end{array}$ & $*$ & Alta \\
\hline Memória & $*$ & $\begin{array}{c}\text { Predisposição para novos } \\
\text { conhecimentos }\end{array}$ & Baixa & Alta \\
\hline Memória & M édia & $\begin{array}{c}\text { Predisposição para novos } \\
\text { conhecimentos }\end{array}$ & Média & M édia \\
\hline Memória & M édia & $\begin{array}{c}\text { Predisposição para novos } \\
\text { conhecimentos }\end{array}$ & Alta & Baixa \\
\hline Memória & Alta & $\begin{array}{c}\text { Predisposição para novos } \\
\text { conhecimentos }\end{array}$ & Média & Baixa \\
\hline
\end{tabular}

O PSF Afago é negativo, isto é, a pessoa desejar proteção ou sofrer de ansiedade constitui um empecilho durante a tomada de decisão.

Um funcionário que seja tranqüilo em relação à ansiedade e não tenha necessidade de proteção (Afago Baixo) ainda terá alta chance de cometer erros se não tiver consideração alguma aos colegas de trabalho/equipe(Afiliação Baixa): será desleal ao tomar decisões que possam afetar negativamente a execução de tarefas de terceiros.

\begin{tabular}{|c|c|c|c|c|}
\hline Afago & Alto & Afiliação & $*$ & Alta \\
\hline Afago & $*$ & Afiliação & Baixa & Alta \\
\hline Afago & Média & Afiliação & Média & M édia \\
\hline Afago & Média & Afiliação & Alta & M édia \\
\hline Afago & Baixa & Afiliação & Média & M édia \\
\hline Afago & Baixa & Afiliação & Alta & Baixa \\
\hline
\end{tabular}


Os demais Fatores de Personalidade são similares na maneira como influenciam a Decisão, refletem como o funcionário irá decidir com base em sua percepção pessoal da sua tarefa e de sua equipe.

\begin{tabular}{|c|c|c|c|c|}
\hline Agressão & Alta & Autonomia & $*$ & Alta \\
\hline Agressão & $*$ & Autonomia & Alta & Alta \\
\hline Agressão & Média & Autonomia & Média & M édia \\
\hline Agressão & Média & Autonomia & Baixa & Média \\
\hline Agressão & Baixa & Autonomia & Média & Média \\
\hline Agressão & Baixa & Autonomia & Baixa & Baixa \\
\hline Assistência & Baixa & Deferência & Baixa & Baixa \\
\hline Assistência & Baixa & Deferência & Média & Média \\
\hline Assistência & Baixa & Deferência & Alta & Alta \\
\hline Assistência & Média & Deferência & Baixa & Baixa \\
\hline Assistência & Média & Deferência & Média & Média \\
\hline Assistência & Média & Deferência & Alta & Média \\
\hline Assistência & Alta & Deferência & Baixa & Baixa \\
\hline Assistência & Alta & Deferência & Média & Média \\
\hline Assistência & Alta & Deferência & Alta & Média \\
\hline Desempenho & Baixo & Dominância & Baixa & Média \\
\hline Desempenho & Baixo & Dominância & Média & Média \\
\hline Desempenho & Baixo & Dominância & Alta & Alta \\
\hline Desempenho & Médio & Dominância & Baixa & Baixa \\
\hline Desempenho & Médio & Dominância & Média & Baixa \\
\hline Desempenho & Médio & Dominância & Alta & Média \\
\hline Desempenho & Alto & Dominância & Baixa & Baixa \\
\hline Desempenho & Alto & Dominância & Média & Baixa \\
\hline Desempenho & Alto & Dominância & Alta & Média \\
\hline Exibição & Baixa & Intracepção & Baixa & Baixa \\
\hline Exibição & Baixa & Intracepção & Média & Média \\
\hline Exibição & Média & Intracepção & Baixa & Média \\
\hline Exibição & Média & Intracepção & Média & Média \\
\hline Exibição & Alta & Intracepção & $*$ & Alta \\
\hline Exibição & $*$ & Intracepção & Alta & Alta \\
\hline
\end{tabular}


Os PSFs Ordem e Persistência do Grupo de PSFs Fatores de Personalidade merecem destaque em relação aos demais. Durante esta fase, tais fatores são responsáveis por definir quão eficiente será o planejamento que o funcionário irá fazer, não por suas capacidades (englobadas pelos PSFs de Fatores Cognitivos) mas sim pela sua vontade em realizar um trabalho bem executado.

\begin{tabular}{|c|c|c|c|c|}
\hline Ordem & Baixa & Persistência & Baixa & Alta \\
\hline Ordem & Baixa & Persistência & Média & Alta \\
\hline Ordem & Baixa & Persistência & Alta & M édia \\
\hline Ordem & Média & Persistência & Baixa & Alta \\
\hline Ordem & Média & Persistência & Média & M édia \\
\hline Ordem & Média & Persistência & Alta & Baixa \\
\hline Ordem & Alta & Persistência & Baixa & M édia \\
\hline Ordem & Alta & Persistência & Média & Baixa \\
\hline Ordem & Alta & Persistência & Alta & Baixa \\
\hline
\end{tabular}

Os PSFs deste SIF são os únicos Fatores Fisiológicos com influência direta nesta etapa. São importantes, pois uma interrupção significa do ritmo circadiano pode prejudicar a forma como funcionário raciocina. Da mesma maneira, manifestações de fome ou sede extremas são capazes de prejudicar o primor de uma pessoa para com suas tarefas.

\begin{tabular}{|c|c|c|c|c|}
\hline Fome ou Sede & Baixa & $\begin{array}{c}\text { Interrupção do Ritmo } \\
\text { Circadiano }\end{array}$ & Baixa & Baixa \\
\hline Fome ou Sede & Baixa & $\begin{array}{c}\text { Interrupção do Ritmo } \\
\text { Circadiano }\end{array}$ & Média & Baixa \\
\hline Fome ou Sede & Baixa & $\begin{array}{c}\text { Interrupção do Ritmo } \\
\text { Circadiano }\end{array}$ & Alta & Média \\
\hline Fome ou Sede & Média & $\begin{array}{c}\text { Interrupção do Ritmo } \\
\text { Circadiano }\end{array}$ & Baixa & Baixa \\
\hline Fome ou Sede & Média & $\begin{array}{c}\text { Interrupção do Ritmo } \\
\text { Circadiano }\end{array}$ & Média & Baixa \\
\hline Fome ou Sede & Média & $\begin{array}{c}\text { Interrupção do Ritmo } \\
\text { Circadiano }\end{array}$ & Alta & Média \\
\hline Fome ou Sede & Alta & $\begin{array}{c}\text { Interrupção do Ritmo } \\
\text { Circadiano }\end{array}$ & Baixa & Média \\
\hline Fome ou Sede & Alta & $\begin{array}{c}\text { Interrupção do Ritmo } \\
\text { Circadiano }\end{array}$ & Média & Média \\
\hline Fome ou Sede & Alta & $\begin{array}{c}\text { Interrupção do Ritmo } \\
\text { Circadiano }\end{array}$ & Alta & Alta \\
\hline
\end{tabular}


Novamente, para melhor exibir o comportamento dos PSFs Ameaças (de Falha, de Perda do Emprego, etc.); Falta de Recompensas, Reconhecimento e Benefícios; e Motivos Conflitantes sobre o Desempenho no Trabalho, suas regras foram separadas em três. No caso de Decisão a influência é bem alta, um fator como Motivos Conflitantes sobre o Desempenho no Trabalho pode por si só causar este erro.

Caso Ameaças (de Falha, de Perda do Emprego, etc.) seja Baixo, ou seja, pouca ou nenhuma Ameaça:

\begin{tabular}{|c|l|c|c|c|}
\hline $\begin{array}{c}\text { Falta de Recompensas, } \\
\text { Reconhecimento e } \\
\text { Benefícios }\end{array}$ & Baixa & $\begin{array}{c}\text { M otivos Conflitantes sobre } \\
\text { o Desempenho no } \\
\text { Trabalho }\end{array}$ & Baixo & Baixa \\
\hline $\begin{array}{c}\text { Falta de Recompensas, } \\
\text { Reconhecimento e } \\
\text { Benefícios }\end{array}$ & Baixa & $\begin{array}{c}\text { M otivos Conflitantes sobre } \\
\text { o Desempenho no } \\
\text { Trabalho }\end{array}$ & Médio & Baixa \\
\hline $\begin{array}{c}\text { Falta de Recompensas, } \\
\text { Reconhecimento e } \\
\text { Benefícios }\end{array}$ & Baixa & $\begin{array}{c}\text { M otivos Conflitantes sobre } \\
\text { o Desempenho no } \\
\text { Trabalho }\end{array}$ & Alto & M édia \\
\hline $\begin{array}{c}\text { Falta de Recompensas, } \\
\text { Reconhecimento e } \\
\text { Benefícios }\end{array}$ & M édia & $\begin{array}{c}\text { M otivos Conflitantes sobre } \\
\text { o Desempenho no } \\
\text { Trabalho }\end{array}$ & Baixo & Baixa \\
\hline $\begin{array}{c}\text { Falta de Recompensas, } \\
\text { Reconhecimento e } \\
\text { Benefícios }\end{array}$ & M édia & $\begin{array}{c}\text { Motivos Conflitantes sobre } \\
\text { o Desempenho no } \\
\text { Trabalho }\end{array}$ & M édio & M édia \\
\hline $\begin{array}{c}\text { Falta de Recompensas, } \\
\text { Reconhecimento e } \\
\text { Benefícios }\end{array}$ & M édia & $\begin{array}{c}\text { Motivos Conflitantes sobre } \\
\text { o Desempenho no } \\
\text { Trabalho }\end{array}$ & Alto & Alta \\
\hline $\begin{array}{c}\text { Falta de Recompensas, } \\
\text { Reconhecimento e } \\
\text { Benefícios }\end{array}$ & Alta & $\begin{array}{c}\text { Motivos Conflitantes sobre } \\
\text { o Desempenho no } \\
\text { Trabalho }\end{array}$ & Baixo & Baixa \\
\hline $\begin{array}{c}\text { Falta de Recompensas, } \\
\text { Reconhecimento e } \\
\text { Benefícios }\end{array}$ & Alta & $\begin{array}{c}\text { M otivos Conflitantes sobre } \\
\text { o Desempenho no } \\
\text { Trabalho }\end{array}$ & Médio & Alta \\
\hline $\begin{array}{c}\text { Falta de Recompensas, } \\
\text { Reconhecimento e } \\
\text { Benefícios }\end{array}$ & Alta & $\begin{array}{c}\text { Motivos Conflitantes sobre } \\
\text { o Desempenho no } \\
\text { Trabalho }\end{array}$ & Alto & Alta \\
\hline
\end{tabular}


Caso Ameaças (de Falha, de Perda do Emprego, etc.) seja Médio:

\begin{tabular}{|c|c|c|c|c|}
\hline $\begin{array}{c}\text { Falta de Recompensas, } \\
\text { Reconhecimento e } \\
\text { Benefícios }\end{array}$ & Baixa & $\begin{array}{c}\text { M otivos Conflitantes sobre } \\
\text { o Desempenho no } \\
\text { Trabalho }\end{array}$ & Baixo & Baixa \\
\hline $\begin{array}{c}\text { Falta de Recompensas, } \\
\text { Reconhecimento e } \\
\text { Benefícios }\end{array}$ & Baixa & $\begin{array}{c}\text { M otivos Conflitantes sobre } \\
\text { o Desempenho no } \\
\text { Trabalho }\end{array}$ & Médio & M édia \\
\hline $\begin{array}{c}\text { Falta de Recompensas, } \\
\text { Reconhecimento e } \\
\text { Benefícios }\end{array}$ & Baixa & $\begin{array}{c}\text { M otivos Conflitantes sobre } \\
\text { o Desempenho no } \\
\text { Trabalho }\end{array}$ & Alto & Alta \\
\hline $\begin{array}{c}\text { Falta de Recompensas, } \\
\text { Reconhecimento e } \\
\text { Benefícios }\end{array}$ & M édia & $\begin{array}{c}\text { Motivos Conflitantes sobre } \\
\text { o Desempenho no } \\
\text { Trabalho }\end{array}$ & Baixo & M édia \\
\hline $\begin{array}{c}\text { Falta de Recompensas, } \\
\text { Reconhecimento e } \\
\text { Benefícios }\end{array}$ & M édia & $\begin{array}{c}\text { Motivos Conflitantes sobre } \\
\text { o Desempenho no } \\
\text { Trabalho }\end{array}$ & Médio & M édia \\
\hline $\begin{array}{c}\text { Falta de Recompensas, } \\
\text { Reconhecimento e } \\
\text { Benefícios }\end{array}$ & Média & $\begin{array}{c}\text { Motivos Conflitantes sobre } \\
\text { o Desempenho no } \\
\text { Trabalho }\end{array}$ & Alto & Alta \\
\hline $\begin{array}{c}\text { Falta de Recompensas, } \\
\text { Reconhecimento e } \\
\text { Benefícios }\end{array}$ & Alta & $\begin{array}{c}\text { Motivos Conflitantes sobre } \\
\text { o Desempenho no } \\
\text { Trabalho }\end{array}$ & Baixo & Alta \\
\hline $\begin{array}{c}\text { Falta de Recompensas, } \\
\text { Reconhecimento e } \\
\text { Benefícios }\end{array}$ & Alta & $\begin{array}{c}\text { Motivos Conflitantes sobre } \\
\text { o Desempenho no } \\
\text { Trabalho }\end{array}$ & M édio & Alta \\
\hline $\begin{array}{c}\text { Falta de Recompensas, } \\
\text { Reconhecimento e } \\
\text { Benefícios }\end{array}$ & Alta & $\begin{array}{c}\text { Motivos Conflitantes sobre } \\
\text { o Desempenho no } \\
\text { Trabalho }\end{array}$ & Alto & Alta \\
\hline
\end{tabular}


Caso Ameaças (de Falha, de Perda do Emprego, etc.) seja Alto:

\begin{tabular}{|c|c|c|c|c|}
\hline $\begin{array}{c}\text { Falta de Recompensas, } \\
\text { Reconhecimento e } \\
\text { Benefícios }\end{array}$ & Baixa & $\begin{array}{c}\text { M otivos Conflitantes sobre } \\
\text { o Desempenho no } \\
\text { Trabalho }\end{array}$ & Baixo & M édia \\
\hline $\begin{array}{c}\text { Falta de Recompensas, } \\
\text { Reconhecimento e } \\
\text { Benefícios }\end{array}$ & Baixa & $\begin{array}{c}\text { Motivos Conflitantes sobre } \\
\text { o Desempenho no } \\
\text { Trabalho }\end{array}$ & Médio & M édia \\
\hline $\begin{array}{c}\text { Falta de Recompensas, } \\
\text { Reconhecimento e } \\
\text { Benefícios }\end{array}$ & Baixa & $\begin{array}{c}\text { Motivos Conflitantes sobre } \\
\text { o Desempenho no } \\
\text { Trabalho }\end{array}$ & Alto & Alta \\
\hline $\begin{array}{c}\text { Falta de Recompensas, } \\
\text { Reconhecimento e } \\
\text { Benefícios }\end{array}$ & Média & $\begin{array}{c}\text { Motivos Conflitantes sobre } \\
\text { o Desempenho no } \\
\text { Trabalho }\end{array}$ & Baixo & M édia \\
\hline $\begin{array}{c}\text { Falta de Recompensas, } \\
\text { Reconhecimento e } \\
\text { Benefícios }\end{array}$ & M édia & $\begin{array}{c}\text { Motivos Conflitantes sobre } \\
\text { o Desempenho no } \\
\text { Trabalho }\end{array}$ & Médio & Alta \\
\hline $\begin{array}{c}\text { Falta de Recompensas, } \\
\text { Reconhecimento e } \\
\text { Benefícios }\end{array}$ & M édia & $\begin{array}{c}\text { Motivos Conflitantes sobre } \\
\text { o Desempenho no } \\
\text { Trabalho }\end{array}$ & Alto \\
\hline $\begin{array}{c}\text { Falta de Recompensas, } \\
\text { Reconhecimento e } \\
\text { Benefícios }\end{array}$ & Alta & $\begin{array}{c}\text { Motivos Conflitantes sobre } \\
\text { o Desempenho no } \\
\text { Trabalho }\end{array}$ & Baixo & M édia \\
\hline $\begin{array}{c}\text { Falta de Recompensas, } \\
\text { Reconhecimento e } \\
\text { Benefícios }\end{array}$ & Alta & $\begin{array}{c}\text { Motivos Conflitantes sobre } \\
\text { o Desempenho no } \\
\text { Trabalho }\end{array}$ & Médio & Alta \\
\hline $\begin{array}{c}\text { Falta de Recompensas, } \\
\text { Beconhecimento e }\end{array}$ & Alta & $\begin{array}{c}\text { Motivos Conflitantes sobre } \\
\text { o Desempenho no } \\
\text { Trabalho }\end{array}$ & Alto & Alta \\
\hline
\end{tabular}

Carga Pesada de Informações trata da quantidade de informação que foi transmitida para o funcionário. Considerando que essa informação foi integralmente recebida, avaliar todos os seus parâmetros durante a etapa de Decisão pode ser crítico. Concomitantemente, ter recebido uma informação que seja causadora de stress atrapalhará a forma como o funcionário irá abordar e planejar sua seqüência de ações. 


\begin{tabular}{|c|c|c|c|c|}
\hline $\begin{array}{c}\text { Carga Pesada de } \\
\text { Informações }\end{array}$ & Baixa & Início Inesperado do Stress & Baixo & Baixa \\
\hline $\begin{array}{c}\text { Carga Pesada de } \\
\text { Informações }\end{array}$ & Baixa & Início Inesperado do Stress & M édio & Baixa \\
\hline $\begin{array}{c}\text { Carga Pesada de } \\
\text { Informações }\end{array}$ & Baixa & Início Inesperado do Stress & Alto & M édia \\
\hline $\begin{array}{c}\text { Carga Pesada de } \\
\text { Informações }\end{array}$ & Média & Início Inesperado do Stress & Baixo & M édia \\
\hline $\begin{array}{c}\text { Carga Pesada de } \\
\text { Informações }\end{array}$ & Média & Início Inesperado do Stress & M édio & M édia \\
\hline $\begin{array}{c}\text { Carga Pesada de } \\
\text { Informações }\end{array}$ & Média & Início Inesperado do Stress & Alto & Alta \\
\hline $\begin{array}{c}\text { Carga Pesada de } \\
\text { Informações }\end{array}$ & Alta & Início Inesperado do Stress & Baixo & Alta \\
\hline $\begin{array}{c}\text { Carga Pesada de } \\
\text { Informações }\end{array}$ & Alta & Início Inesperado do Stress & Médio & Alta \\
\hline $\begin{array}{c}\text { Carga Pesada de } \\
\text { Informações }\end{array}$ & Alta & Início Inesperado do Stress & Alto & Alta \\
\hline
\end{tabular}

Os fatores englobados pelo SIF abaixo tratam de características momentâneas, ainda que cruciais. Sofrer qualquer espécie de distração no momento da tomada de decisão diminuirá a qualidade desta, assim como ter algum sentido falhando. É de se esperar que a influência maior desses PSFs seja no momento da Ação, porém o impacto mental também deve ser considerado.

\begin{tabular}{|c|c|c|c|c|}
\hline $\begin{array}{c}\text { Distrações (devido a Ruído, } \\
\text { Clarão, M ovimentos, etc.) }\end{array}$ & Baixa & Perda de Sensibilidade & Baixa & Baixa \\
\hline $\begin{array}{c}\text { Distrações (devido a Ruído, } \\
\text { Clarão, M ovimentos, etc.) }\end{array}$ & Baixa & Perda de Sensibilidade & M édia & Baixa \\
\hline $\begin{array}{c}\text { Distrações (devido a Ruído, } \\
\text { Clarão, M ovimentos, etc.) }\end{array}$ & Baixa & Perda de Sensibilidade & Alta & M édia \\
\hline $\begin{array}{c}\text { Distrações (devido a Ruído, } \\
\text { Clarão, M ovimentos, etc.) }\end{array}$ & M édia & Perda de Sensibilidade & Baixa & M édia \\
\hline $\begin{array}{c}\text { Distrações (devido a Ruído, } \\
\text { Clarão, M ovimentos, etc.) }\end{array}$ & M édia & Perda de Sensibilidade & M édia & M édia \\
\hline $\begin{array}{c}\text { Distrações (devido a Ruído, } \\
\text { Clarão, M ovimentos, etc.) }\end{array}$ & Média & Perda de Sensibilidade & Alta & Alta \\
\hline $\begin{array}{c}\text { Distrações (devido a Ruído, } \\
\text { Clarão, M ovimentos, etc.) }\end{array}$ & Alta & Perda de Sensibilidade & Baixa & M édia \\
\hline $\begin{array}{c}\text { Distrações (devido a Ruído, } \\
\text { Clarão, Movimentos, etc.) }\end{array}$ & Alta & Perda de Sensibilidade & M édia & Alta \\
\hline $\begin{array}{c}\text { Distrações (devido a Ruído, } \\
\text { Clarão, Movimentos, etc.) }\end{array}$ & Alta & Perda de Sensibilidade & Alta & Alta \\
\hline
\end{tabular}




\begin{tabular}{|c|c|c|c|c|}
\hline $\begin{array}{l}\text { Períodos de Vigilância } \\
\text { Longos, sem } \\
\text { Acontecimentos }\end{array}$ & Baixa & $\begin{array}{c}\text { Trabalho M onótono, } \\
\text { Degradante ou Sem } \\
\text { Sentido }\end{array}$ & Baixa & Baixa \\
\hline $\begin{array}{l}\text { Períodos de Vigilância } \\
\text { Longos, sem } \\
\text { Acontecimentos }\end{array}$ & Baixa & $\begin{array}{l}\text { Trabalho M onótono, } \\
\text { Degradante ou Sem } \\
\text { Sentido }\end{array}$ & Média & Baixa \\
\hline $\begin{array}{l}\text { Períodos de Vigilância } \\
\text { Longos, sem } \\
\text { Acontecimentos }\end{array}$ & Baixa & $\begin{array}{c}\text { Trabalho M onótono, } \\
\text { Degradante ou Sem } \\
\text { Sentido }\end{array}$ & Alta & Média \\
\hline $\begin{array}{l}\text { Períodos de Vigilância } \\
\text { Longos, sem } \\
\text { Acontecimentos }\end{array}$ & Média & $\begin{array}{c}\text { Trabalho M onótono, } \\
\text { Degradante ou Sem } \\
\text { Sentido }\end{array}$ & Baixa & Baixa \\
\hline $\begin{array}{l}\text { Períodos de Vigilância } \\
\text { Longos, sem } \\
\text { Acontecimentos }\end{array}$ & Média & $\begin{array}{c}\text { Trabalho M onótono, } \\
\text { Degradante ou Sem } \\
\text { Sentido }\end{array}$ & Média & Média \\
\hline $\begin{array}{l}\text { Períodos de Vigilância } \\
\text { Longos, sem } \\
\text { Acontecimentos }\end{array}$ & Média & $\begin{array}{c}\text { Trabalho M onótono, } \\
\text { Degradante ou Sem } \\
\text { Sentido }\end{array}$ & Alta & Alta \\
\hline $\begin{array}{l}\text { Períodos de Vigilância } \\
\text { Longos, sem } \\
\text { Acontecimentos }\end{array}$ & Alta & $\begin{array}{c}\text { Trabalho M onótono, } \\
\text { Degradante ou Sem } \\
\text { Sentido }\end{array}$ & Baixa & Média \\
\hline $\begin{array}{l}\text { Períodos de Vigilância } \\
\text { Longos, sem } \\
\text { Acontecimentos }\end{array}$ & Alta & $\begin{array}{c}\text { Trabalho M onótono, } \\
\text { Degradante ou Sem } \\
\text { Sentido }\end{array}$ & Média & Alta \\
\hline $\begin{array}{l}\text { Períodos de Vigilância } \\
\text { Longos, sem } \\
\text { Acontecimentos }\end{array}$ & Alta & $\begin{array}{c}\text { Trabalho M onótono, } \\
\text { Degradante ou Sem } \\
\text { Sentido }\end{array}$ & Alta & Alta \\
\hline
\end{tabular}

Os PSFs aqui avaliados são de influência direta sobre esta etapa. Dois aspectos de ambos devem ser considerados: com que frequiência ocorrem, e como o funcionário se deixa abalar por eles. Evidentemente, caso o colaborador se deixe influenciar por palpites, comentários ou interrupções não construtivas sua decisão ficará debilitada.

\begin{tabular}{|c|c|c|c|c|}
\hline Reforço Negativo & Baixa & Sugestões Inconsistentes & Baixa & Baixa \\
\hline Reforço Negativo & Baixa & Sugestões Inconsistentes & Média & M édia \\
\hline Reforço Negativo & Baixa & Sugestões Inconsistentes & Alta & M édia \\
\hline Reforço Negativo & Média & Sugestões Inconsistentes & Baixa & M édia \\
\hline Reforço Negativo & Média & Sugestões Inconsistentes & Média & M édia \\
\hline Reforço Negativo & Média & Sugestões Inconsistentes & Alta & Alta \\
\hline Reforço Negativo & Alta & Sugestões Inconsistentes & Baixa & M édia \\
\hline Reforço Negativo & Alta & Sugestões Inconsistentes & Média & Alta \\
\hline Reforço Negativo & Alta & Sugestões Inconsistentes & Alta & Alta \\
\hline
\end{tabular}


Para que o planejamento de uma tarefa possa ser eficientemente construído, se faz necessário saber o que outros membros de sua equipe estão fazendo, sejam eles de igual nível hierárquico dentro da empresa, de maior nível ou ainda de fiscalização. Não só isso, mas também estar ciente de como as ações dos demais irão impactar no seu próprio desempenho.

\begin{tabular}{|c|c|c|c|c|}
\hline $\begin{array}{l}\text { Ações desenvolvidas por } \\
\text { Supervisores, Colegas, } \\
\text { Representantes de } \\
\text { Sindicatos, e Pessoal de } \\
\text { Regulamentação }\end{array}$ & $*$ & Comunicação & Baixa & Alta \\
\hline $\begin{array}{l}\text { Ações desenvolvidas por } \\
\text { Supervisores, Colegas, } \\
\text { Representantes de } \\
\text { Sindicatos, e Pessoal de } \\
\text { Regulamentação }\end{array}$ & Baixa & Comunicação & Média & M édia \\
\hline $\begin{array}{l}\text { Ações desenvolvidas por } \\
\text { Supervisores, Colegas, } \\
\text { Representantes de } \\
\text { Sindicatos, e Pessoal de } \\
\text { Regulamentação }\end{array}$ & Baixa & Comunicação & Alta & Média \\
\hline $\begin{array}{l}\text { Ações desenvolvidas por } \\
\text { Supervisores, Colegas, } \\
\text { Representantes de } \\
\text { Sindicatos, e Pessoal de } \\
\text { Regulamentação }\end{array}$ & Média & Comunicação & Média & Média \\
\hline $\begin{array}{l}\text { Ações desenvolvidas por } \\
\text { Supervisores, Colegas, } \\
\text { Representantes de } \\
\text { Sindicatos, e Pessoal de } \\
\text { Regulamentação }\end{array}$ & Média & Comunicação & Alta & Baixa \\
\hline $\begin{array}{l}\text { Ações desenvolvidas por } \\
\text { Supervisores, Colegas, } \\
\text { Representantes de } \\
\text { Sindicatos, e Pessoal de } \\
\text { Regulamentação }\end{array}$ & Alta & Comunicação & M édia & Baixa \\
\hline $\begin{array}{l}\text { Ações desenvolvidas por } \\
\text { Supervisores, Colegas, } \\
\text { Representantes de } \\
\text { Sindicatos, e Pessoal de } \\
\text { Regulamentação }\end{array}$ & Alta & Comunicação & Alta & Baixa \\
\hline
\end{tabular}

O nível de importância da tarefa para o procedimento como um todo irá impactar no nervosismo do funcionário, bem como demandará maior qualidade no planejamento. Uma tarefa complexa e com alto nível de importância exigirá que o operador tenha fatores de personalidade e cognitivos capazes de lidar corretamente com o "peso" imposto por elas. Tal correlação é tratada por SIFs dos 
níveis hierárquicos seguintes, conforme diferentes PSFs começam a ser avaliados em conjunto.

\begin{tabular}{|c|c|c|c|c|}
\hline $\begin{array}{c}\text { Capacidade Crítica da } \\
\text { Tarefa }\end{array}$ & Baixa & $\begin{array}{c}\text { Complexidade da Tarefa } \\
\text { (Carga de Informações) }\end{array}$ & Baixa & Baixa \\
\hline $\begin{array}{c}\text { Capacidade Crítica da } \\
\text { Tarefa }\end{array}$ & Baixa & $\begin{array}{c}\text { Complexidade da Tarefa } \\
\text { (Carga de Informações) }\end{array}$ & M édia & M édia \\
\hline $\begin{array}{c}\text { Capacidade Crítica da } \\
\text { Tarefa }\end{array}$ & $*$ & $\begin{array}{c}\text { Complexidade da Tarefa } \\
\text { (Carga de Informações) }\end{array}$ & Alta & Alta \\
\hline $\begin{array}{c}\text { Capacidade Crítica da } \\
\text { Tarefa }\end{array}$ & Média & $\begin{array}{c}\text { Complexidade da Tarefa } \\
\text { (Carga de Informações) }\end{array}$ & Baixa & M édia \\
\hline $\begin{array}{c}\text { Capacidade Crítica da } \\
\text { Tarefa }\end{array}$ & Média & $\begin{array}{c}\text { Complexidade da Tarefa } \\
\text { (Carga de Informações) }\end{array}$ & Média & M édia \\
\hline $\begin{array}{c}\text { Capacidade Crítica da } \\
\text { Tarefa }\end{array}$ & Alta & $\begin{array}{c}\text { Complexidade da Tarefa } \\
\text { (Carga de Informações) }\end{array}$ & $*$ & Alta \\
\hline
\end{tabular}

Como o SIF a seguir é composto por três variáveis (Disponibilidade de Equipamentos Especiais, Instrumentos, e Insumos), suas regras foram separadas em três. Os três abordam a existência de materiais para que o colaborador possa executar sua tarefa. Equipamentos Especiais considera a necessidade de uma ferramenta específica para uma determinada tarefa; Instrumentos avalia a existência de uma ferramenta comum, que múltiplos colaboradores possam estar usando ao mesmo tempo (desde que esta esteja disponível em quantidade grande o suficiente); e Insumos trata da disponibilidade de um material não-durável, que é gasto parcial ou totalmente durante a execução da tarefa.

Caso Disponibilidade de Equipamentos Especiais seja Baixa:

\begin{tabular}{|c|c|c|c|c|}
\hline Instrumentos & Baixo & Insumos & Baixo & Alta \\
\hline Instrumentos & Baixo & Insumos & Médio & Alta \\
\hline Instrumentos & Baixo & Insumos & Alto & Alta \\
\hline Instrumentos & Médio & Insumos & Baixo & Alta \\
\hline Instrumentos & Médio & Insumos & Médio & Média \\
\hline Instrumentos & Médio & Insumos & Alto & Média \\
\hline Instrumentos & Alto & Insumos & Baixo & Alta \\
\hline Instrumentos & Alto & Insumos & Médio & Média \\
\hline Instrumentos & Alto & Insumos & Alto & Média \\
\hline
\end{tabular}


Caso Disponibilidade de Equipamentos Especiais seja Média:

\begin{tabular}{|c|c|c|c|c|}
\hline Instrumentos & Baixo & Insumos & Baixo & Alta \\
\hline Instrumentos & Baixo & Insumos & Médio & M édia \\
\hline Instrumentos & Baixo & Insumos & Alto & M édia \\
\hline Instrumentos & Médio & Insumos & Baixo & M édia \\
\hline Instrumentos & Médio & Insumos & Médio & M édia \\
\hline Instrumentos & Médio & Insumos & Alto & M édia \\
\hline Instrumentos & Alto & Insumos & Baixo & M édia \\
\hline Instrumentos & Alto & Insumos & Médio & M édia \\
\hline Instrumentos & Alto & Insumos & Alto & Baixa \\
\hline
\end{tabular}

Caso Disponibilidade de Equipamentos Especiais seja Alta:

\begin{tabular}{|c|c|c|c|c|}
\hline Instrumentos & Baixo & Insumos & Baixo & Alta \\
\hline Instrumentos & Baixo & Insumos & Médio & M édia \\
\hline Instrumentos & Baixo & Insumos & Alto & M édia \\
\hline Instrumentos & Médio & Insumos & Baixo & M édia \\
\hline Instrumentos & Médio & Insumos & Médio & M édia \\
\hline Instrumentos & Médio & Insumos & Alto & Baixa \\
\hline Instrumentos & Alto & Insumos & Baixo & M édia \\
\hline Instrumentos & Alto & Insumos & Médio & Baixa \\
\hline Instrumentos & Alto & Insumos & Alto & Baixa \\
\hline
\end{tabular}

\begin{tabular}{|c|c|c|c|c|}
\hline Estrutura de Equipe & Baixa & Estrutura Organizacional & Baixa & Alta \\
\hline Estrutura de Equipe & Baixa & Estrutura Organizacional & Média & M édia \\
\hline Estrutura de Equipe & Baixa & Estrutura Organizacional & Alta & M édia \\
\hline Estrutura de Equipe & Média & Estrutura Organizacional & Baixa & Alta \\
\hline Estrutura de Equipe & Média & Estrutura Organizacional & Média & M édia \\
\hline Estrutura de Equipe & Média & Estrutura Organizacional & Alta & Baixa \\
\hline Estrutura de Equipe & Alta & Estrutura Organizacional & Baixa & Alta \\
\hline Estrutura de Equipe & Alta & Estrutura Organizacional & Média & M édia \\
\hline Estrutura de Equipe & Alta & Estrutura Organizacional & Alta & Baixa \\
\hline
\end{tabular}

A Freqüência e Repetitividade da Tarefa pode ser boa, no que diz respeito ao aumento do número de práticas, e especialização; mas também pode ser ruim, se considerarmos que o funcionário pode ficar cansado (mental ou fisicamente) por realizar a mesma tarefas repetidas vezes. Dessa forma, percebe-se a importância de avaliá-la junto ao PSF Horas de Trabalho / Intervalos de Trabalho, pois permite levar em consideração a duração da tarefa repetitiva, bem como o quanto de descanso foi ministrado ao funcionário entre execuções. 
Para a Decisão, se o funcionário está desempenhando a mesma tarefa varias vezes, a seqüência do que deve fazer já está decorada/"automática"/bem conhecida por ele. A influência dos intervalos de trabalho só tem a ajudar, caso esteja mais descansado poderá tomar melhores decisões.

\begin{tabular}{|c|c|c|c|c|}
\hline $\begin{array}{c}\text { Freqüência e } \\
\text { Repetitividade da Tarefa }\end{array}$ & Baixa & $\begin{array}{l}\text { Horas de Trabalho / } \\
\text { Intervalos de Trabalho }\end{array}$ & Baixa & Alta \\
\hline $\begin{array}{c}\text { Freqüência e } \\
\text { Repetitividade da Tarefa }\end{array}$ & Baixa & $\begin{array}{l}\text { Horas de Trabalho / } \\
\text { Intervalos de Trabalho }\end{array}$ & Média & Alta \\
\hline $\begin{array}{c}\text { Freqüência e } \\
\text { Repetitividade da Tarefa }\end{array}$ & Baixa & $\begin{array}{l}\text { Horas de Trabalho / } \\
\text { Intervalos de Trabalho }\end{array}$ & Alta & Média \\
\hline $\begin{array}{c}\text { Freqüência e } \\
\text { Repetitividade da Tarefa }\end{array}$ & Média & $\begin{array}{l}\text { Horas de Trabalho / } \\
\text { Intervalos de Trabalho }\end{array}$ & Baixa & Média \\
\hline $\begin{array}{c}\text { Freqüência e } \\
\text { Repetitividade da Tarefa }\end{array}$ & Média & $\begin{array}{l}\text { Horas de Trabalho / } \\
\text { Intervalos de Trabalho }\end{array}$ & Média & Baixa \\
\hline $\begin{array}{c}\text { Freqüência e } \\
\text { Repetitividade da Tarefa }\end{array}$ & Média & $\begin{array}{c}\text { Horas de Trabalho / } \\
\text { Intervalos de Trabalho }\end{array}$ & Alta & Baixa \\
\hline $\begin{array}{c}\text { Freqüência e } \\
\text { Repetitividade da Tarefa }\end{array}$ & Alta & $\begin{array}{c}\text { Horas de Trabalho / } \\
\text { Intervalos de Trabalho }\end{array}$ & Baixa & Baixa \\
\hline $\begin{array}{c}\text { Freqüência e } \\
\text { Repetitividade da Tarefa }\end{array}$ & Alta & $\begin{array}{c}\text { Horas de Trabalho / } \\
\text { Intervalos de Trabalho }\end{array}$ & Média & Baixa \\
\hline $\begin{array}{c}\text { Freqüência e } \\
\text { Repetitividade da Tarefa }\end{array}$ & Alta & $\begin{array}{l}\text { Horas de Trabalho / } \\
\text { Intervalos de Trabalho }\end{array}$ & Alta & Baixa \\
\hline
\end{tabular}

Conhecer os métodos usuais e boas práticas influenciam diretamente no momento interno ao operador: Decisão. Por melhor intencionado que seja o funcionário, caso desconheça as regras da empresa seu planejamento não será tão bem desenvolvido perante aos conceitos internos de boas práticas.

\begin{tabular}{|c|c|c|c|c|}
\hline Métodos de Trabalho & Baixo & Políticas da Planta & Baixa & Alta \\
\hline Métodos de Trabalho & Baixo & Políticas da Planta & Média & Alta \\
\hline Métodos de Trabalho & Baixo & Políticas da Planta & Alta & M édia \\
\hline Métodos de Trabalho & Médio & Políticas da Planta & Baixa & Alta \\
\hline Métodos de Trabalho & Médio & Políticas da Planta & Média & M édia \\
\hline Métodos de Trabalho & Médio & Políticas da Planta & Alta & Baixa \\
\hline Métodos de Trabalho & Alto & Políticas da Planta & Baixa & M édia \\
\hline Métodos de Trabalho & Alto & Políticas da Planta & Média & Baixa \\
\hline Métodos de Trabalho & Alto & Políticas da Planta & Alta & Baixa \\
\hline
\end{tabular}

Os PSFs do SIF abaixo são similares aos o SIF anterior, no que diz respeito a nível de conhecimento de como as tarefas devem ser desempenhadas dentro de sua empresa. Enquanto os anteriores são gerais, estes são pontuais, variam com a 
situação em que se encontram. Decidir ou planejar sem saber quão boa foi sua decisão anterior, e em que ela acarretou, pode ser crítico. Da mesma maneira, desconhecer ou ter um conhecimento equivocado de quais são os procedimentos adequados é potencialmente adverso para um bom desempenho.

Estes PSFs são indiferentes para a etapa seguinte (Ação), pois conhecer os resultados não afeta erros de execução, apenas indiretamente: é pertinente no momento de decidir como agir, o que caracteriza a etapa de Decisão, não podendo ser considerado um lapso.

\begin{tabular}{|c|c|c|c|c|}
\hline $\begin{array}{c}\text { Feedback (Conhecimento } \\
\text { de Resultados) }\end{array}$ & Baixo & $\begin{array}{c}\text { Procedimentos (Escritos ou } \\
\text { Não Escritos) }\end{array}$ & Baixo & Alta \\
\hline $\begin{array}{c}\text { Feedback (Conhecimento } \\
\text { de Resultados) }\end{array}$ & Baixo & $\begin{array}{c}\text { Procedimentos (Escritos ou } \\
\text { Não Escritos) }\end{array}$ & M édio & Alta \\
\hline $\begin{array}{c}\text { Feedback (Conhecimento } \\
\text { de Resultados) }\end{array}$ & Baixo & $\begin{array}{c}\text { Procedimentos (Escritos ou } \\
\text { Não Escritos) }\end{array}$ & Alto & M édia \\
\hline $\begin{array}{c}\text { Feedback (Conhecimento } \\
\text { de Resultados) }\end{array}$ & M édio & $\begin{array}{c}\text { Procedimentos (Escritos ou } \\
\text { Não Escritos) }\end{array}$ & Baixo & Alta \\
\hline $\begin{array}{c}\text { Feedback (Conhecimento } \\
\text { de Resultados) }\end{array}$ & Médio & $\begin{array}{c}\text { Procedimentos (Escritos ou } \\
\text { Não Escritos) }\end{array}$ & M édio & M édia \\
\hline $\begin{array}{c}\text { Feedback (Conhecimento } \\
\text { de Resultados) }\end{array}$ & Médio & $\begin{array}{c}\text { Procedimentos (Escritos ou } \\
\text { Não Escritos) }\end{array}$ & Alto & Baixa \\
\hline $\begin{array}{c}\text { Feedback (Conhecimento } \\
\text { de Resultados) }\end{array}$ & Alto & $\begin{array}{c}\text { Procedimentos (Escritos ou } \\
\text { Não Escritos) }\end{array}$ & Baixo & Alta \\
\hline $\begin{array}{c}\text { Feedback (Conhecimento } \\
\text { de Resultados) }\end{array}$ & Alto & $\begin{array}{c}\text { Procedimentos (Escritos ou } \\
\text { Não Escritos) }\end{array}$ & M édio & Baixa \\
\hline $\begin{array}{c}\text { Feedback (Conhecimento } \\
\text { de Resultados) }\end{array}$ & Alto & $\begin{array}{c}\text { Procedimentos (Escritos ou } \\
\text { Não Escritos) }\end{array}$ & Alto & Baixa \\
\hline
\end{tabular}

Conforme já explicado na etapa de Informação, os PSFs deste SIF influenciam em todas as etapas. Claramente, problemas de saúde afetam a Decisão, seja por motivos fisiológicos ou por diminuir o ânimo do funcionário.

Problemas pessoais externos podem afetar todas as etapas também, por serem capazes de variar consideravelmente o comportamento psicológico de uma pessoa, afetam diretamente o senso de como percebem e avaliam o ambiente que lhe cerca. 


\begin{tabular}{|c|c|c|c|c|}
\hline Condição Física/Saúde & Baixa & $\begin{array}{c}\text { Influência de outros } \\
\text { agentes externos (pessoas, } \\
\text { família) }\end{array}$ & $*$ & Alta \\
\hline Condição Física/Saúde & $*$ & $\begin{array}{c}\text { Influência de outros } \\
\text { agentes externos (pessoas, } \\
\text { família) }\end{array}$ & Baixa & Alta \\
\hline Condição Física/Saúde & Média & $\begin{array}{c}\text { Influência de outros } \\
\text { agentes externos (pessoas, } \\
\text { família) }\end{array}$ & Média & M édia \\
\hline Condição Física/Saúde & Média & $\begin{array}{c}\text { Influência de outros } \\
\text { agentes externos (pessoas, } \\
\text { família) }\end{array}$ & Alta & Baixa \\
\hline Condição Física/Saúde & Alta & $\begin{array}{c}\text { Influência de outros } \\
\text { agentes externos (pessoas, } \\
\text { família) }\end{array}$ & Média & Baixa \\
\hline Condição Física/Saúde & Alta & $\begin{array}{c}\text { Influência de outros } \\
\text { agentes externos (pessoas, } \\
\text { família) }\end{array}$ & Alta & Baixa \\
\hline
\end{tabular}

Os PSFs abaixo são essenciais para a Decisão. Conhecimento de Padrões de Desempenho significa saber qual o nível de qualidade esperado para cada etapa dos procedimentos da empresa, o que juntamente com Experiência molda a maneira do funcionário planejar suas ações futuras.

\begin{tabular}{|c|c|c|c|c|}
\hline $\begin{array}{c}\text { Conhecimento de Padrões } \\
\text { de Desempenho }\end{array}$ & Baixo & Experiência & Baixa & Alta \\
\hline $\begin{array}{c}\text { Conhecimento de Padrões } \\
\text { de Desempenho }\end{array}$ & Baixo & Experiência & M édia & Alta \\
\hline $\begin{array}{c}\text { Conhecimento de Padrões } \\
\text { de Desempenho }\end{array}$ & Baixo & Experiência & Alta & M édia \\
\hline $\begin{array}{c}\text { Conhecimento de Padrões } \\
\text { de Desempenho }\end{array}$ & Médio & Experiência & Baixa & Alta \\
\hline $\begin{array}{c}\text { Conhecimento de Padrões } \\
\text { de Desempenho }\end{array}$ & Médio & Experiência & Média & M édia \\
\hline $\begin{array}{c}\text { Conhecimento de Padrões } \\
\text { de Desempenho }\end{array}$ & Médio & Experiência & Alta & Baixa \\
\hline $\begin{array}{c}\text { Conhecimento de Padrões } \\
\text { de Desempenho }\end{array}$ & Alto & Experiência & Baixa & M édia \\
\hline $\begin{array}{c}\text { Conhecimento de Padrões } \\
\text { de Desempenho }\end{array}$ & Alto & Experiência & Média & Baixa \\
\hline $\begin{array}{c}\text { Conhecimento de Padrões } \\
\text { de Desempenho }\end{array}$ & Alto & Experiência & Alta & Baixa \\
\hline
\end{tabular}

A Motivação, bem como a Tensão Mental pode alterar a "working memory", fazendo com que o colaborador tenha deficiências na sua capacidade de planejamento. 


\begin{tabular}{|c|c|c|c|c|}
\hline Motivação & Baixa & Tensão Mental ou Física & Baixa & M édia \\
\hline Motivação & Baixa & Tensão M ental ou Física & Média & Alta \\
\hline Motivação & Baixa & Tensão M ental ou Física & Alta & Alta \\
\hline Motivação & Média & Tensão M ental ou Física & Baixa & Baixa \\
\hline M otivação & Média & Tensão M ental ou Física & Média & M édia \\
\hline Motivação & Média & Tensão Mental ou Física & Alta & Alta \\
\hline Motivação & Alta & Tensão M ental ou Física & Baixa & Baixa \\
\hline Motivação & Alta & Tensão Mental ou Física & Média & Baixa \\
\hline Motivação & Alta & Tensão Mental ou Física & Alta & M édia \\
\hline
\end{tabular}

É crucial para o bom desempenho das tarefas seu planejamento e as decisões tomadas a seu respeito levem em consideração as regras internas da empresa, sejam elas sobre segurança ou organizacionais.

\begin{tabular}{|c|c|c|c|c|}
\hline $\begin{array}{l}\text { Nível de cultura de } \\
\text { segurança }\end{array}$ & Baixo & $\begin{array}{l}\text { Nível de cultura } \\
\text { organizacional }\end{array}$ & Baixo & Alta \\
\hline $\begin{array}{c}\text { Nível de cultura de } \\
\text { segurança }\end{array}$ & Baixo & $\begin{array}{l}\text { Nível de cultura } \\
\text { organizacional }\end{array}$ & Médio & Alta \\
\hline $\begin{array}{l}\text { Nível de cultura de } \\
\text { segurança }\end{array}$ & Baixo & $\begin{array}{l}\text { Nível de cultura } \\
\text { organizacional }\end{array}$ & Alto & Média \\
\hline $\begin{array}{c}\text { Nível de cultura de } \\
\text { segurança }\end{array}$ & Médio & $\begin{array}{l}\text { Nível de cultura } \\
\text { organizacional }\end{array}$ & Baixo & Alta \\
\hline $\begin{array}{l}\text { Nível de cultura de } \\
\text { segurança }\end{array}$ & M édio & $\begin{array}{l}\text { Nível de cultura } \\
\text { organizacional }\end{array}$ & Médio & Média \\
\hline $\begin{array}{c}\text { Nível de cultura de } \\
\text { segurança }\end{array}$ & M édio & $\begin{array}{l}\text { Nível de cultura } \\
\text { organizacional }\end{array}$ & Alto & Baixa \\
\hline $\begin{array}{c}\text { Nível de cultura de } \\
\text { segurança }\end{array}$ & Alto & $\begin{array}{l}\text { Nível de cultura } \\
\text { organizacional }\end{array}$ & Baixo & M édia \\
\hline $\begin{array}{l}\text { Nível de cultura de } \\
\text { segurança }\end{array}$ & Alto & $\begin{array}{l}\text { Nível de cultura } \\
\text { organizacional }\end{array}$ & Médio & Baixa \\
\hline $\begin{array}{c}\text { Nível de cultura de } \\
\text { segurança }\end{array}$ & Alto & $\begin{array}{c}\text { Nível de cultura } \\
\text { organizacional }\end{array}$ & Alto & Baixa \\
\hline
\end{tabular}

Evidentemente, a quantidade de vezes que o funcionário realizou a tarefa influenciará diretamente na qualidade das decisões que poderá tomar antes de realizá-la novamente. De maneira similar, a Qualidade do Treinamento também é responsável por grande impacto nesta etapa, pois permite ao funcionário colocar em prática conceitos absorvidos anteriormente. 


\begin{tabular}{|c|c|c|c|c|}
\hline Nível de práticas & Baixo & Qualidade do Treinamento & Baixa & Alta \\
\hline Nível de práticas & Baixo & Qualidade do Treinamento & Média & Alta \\
\hline Nível de práticas & Baixo & Qualidade do Treinamento & Alta & M édia \\
\hline Nível de práticas & Médio & Qualidade do Treinamento & Baixa & Alta \\
\hline Nível de práticas & Médio & Qualidade do Treinamento & Média & M édia \\
\hline Nível de práticas & Médio & Qualidade do Treinamento & Alta & Baixa \\
\hline Nível de práticas & Alto & Qualidade do Treinamento & Baixa & M édia \\
\hline Nível de práticas & Alto & Qualidade do Treinamento & Média & Baixa \\
\hline Nível de práticas & Alto & Qualidade do Treinamento & Alta & Baixa \\
\hline
\end{tabular}

\subsubsection{2.}

\section{SIFs Hierárquicos do Segundo Nível}

Vale ressaltar que a partir do Segundo Nível até o nível final, todas as variáveis são possibilidades de erro e não mais desempenho dos PSFs; e que caso uma variável esteja com comportamento Alto significa que a possibilidade de seus PSFs falharem é grande, dessa forma, representa uma avaliação negativa para a tarefa.

O PSF Capacidade de Tomada de Decisões é referente à capacidade do funcionário de resolver como agir diante de uma situação em que seu conhecimento, experiência, e bom senso estão sendo requisitados. O tipo de erro Decisão é referente à todas as questões internas ao funcionário após o recebimento da Informação e antes da Ação, sendo assim, apesar do termo "decisões" estar presente no nome de um dos PSFs aqui analisados, os demais também tem grande importância para esta etapa. 


\begin{tabular}{|c|c|c|c|c|}
\hline $\begin{array}{c}\text { Se possibilidade de erro } \\
\text { de Informação do Sub- } \\
\text { grupo }\end{array}$ & é & $\begin{array}{c}\text { e possibilidade de erro de } \\
\text { Informação do Sub-grupo }\end{array}$ & é & $\begin{array}{c}\text { Então } \\
\text { possibilidade } \\
\text { de erro de } \\
\text { Decisão é }\end{array}$ \\
\hline $\begin{array}{c}\text { Capacidade Analítica } \\
\text { Capacidade de } \\
\text { Classificação }\end{array}$ & Baixa & $\begin{array}{c}\text { Capacidade de } \\
\text { Antecipação } \\
\text { Capacidade de Tomada de } \\
\text { Decisões }\end{array}$ & Baixa & Baixa \\
\hline II & Baixa & II & M édia & Baixa \\
\hline II & Baixa & II & Alta & M édia \\
\hline II & Média & II & Baixa & Baixa \\
\hline II & Média & II & M édia & M édia \\
\hline II & Média & II & Alta & Alta \\
\hline II & Alta & II & Baixa & M édia \\
\hline II & Alta & II & M édia & Alta \\
\hline II & Alta & II & Alta & Alta \\
\hline
\end{tabular}

O SIF abaixo, bem como o anterior, é constituído por PSFs muito importantes para a Decisão, por se tratarem de Fatores Cognitivos.

\begin{tabular}{|c|c|c|c|c|}
\hline $\begin{array}{c}\text { Inteligência numérica } \\
\text { (capacidade de cálculos) } \\
\text { Percepção de séries }\end{array}$ & Baixa & $\begin{array}{c}\text { Memória } \\
\text { Predisposição para novos } \\
\text { conhecimentos }\end{array}$ & Baixa & Baixa \\
\hline II & Baixa & II & Média & Média \\
\hline II & Baixa & II & Alta & Média \\
\hline II & Média & II & Baixa & Baixa \\
\hline II & Média & II & Média & M édia \\
\hline II & Média & II & Alta & Alta \\
\hline II & Alta & II & Baixa & Média \\
\hline II & Alta & II & Média & Alta \\
\hline II & Alta & II & Alta & Alta \\
\hline
\end{tabular}

Apesar de um sub-grupo influenciar no outro da mesma maneira que ocorre nos outros SIFs que tratam de Fatores de Personalidade para esta etapa, é importante lembrar que, no primeiro nível, os PSFs Ordem e Persistência são os mais importantes para a Decisão. 


\begin{tabular}{|c|c|c|c|c|}
\hline $\begin{array}{c}\text { Afago } \\
\text { Afiliação }\end{array}$ & Baixa & $\begin{array}{c}\text { Agressão } \\
\text { Autonomia }\end{array}$ & Baixa & Baixa \\
\hline II & Baixa & II & Média & Baixa \\
\hline II & Baixa & II & Alta & Média \\
\hline II & Média & II & Baixa & Baixa \\
\hline II & Média & II & Média & Média \\
\hline II & Média & II & Alta & Alta \\
\hline II & Alta & II & Baixa & Média \\
\hline II & Alta & II & Média & Alta \\
\hline II & Alta & II & Alta & Alta \\
\hline $\begin{array}{l}\text { Desempenho } \\
\text { Dominância }\end{array}$ & Baixa & $\begin{array}{c}\text { Ordem } \\
\text { Persistência }\end{array}$ & Baixa & Baixa \\
\hline II & Baixa & II & Média & Baixa \\
\hline II & Baixa & II & Alta & Média \\
\hline II & Média & II & Baixa & Baixa \\
\hline II & Média & II & Média & Média \\
\hline II & Média & II & Alta & Alta \\
\hline II & Alta & II & Baixa & Média \\
\hline II & Alta & II & Média & Alta \\
\hline II & Alta & II & Alta & Alta \\
\hline $\begin{array}{l}\text { Assistência } \\
\text { Deferência }\end{array}$ & Baixa & $\begin{array}{c}\text { Exibição } \\
\text { Intracepção }\end{array}$ & Baixa & Baixa \\
\hline II & Baixa & II & Média & Baixa \\
\hline II & Baixa & II & Alta & M édia \\
\hline II & Média & II & Baixa & Baixa \\
\hline II & Média & II & Média & Média \\
\hline II & Média & II & Alta & Alta \\
\hline II & Alta & II & Baixa & Média \\
\hline II & Alta & II & Média & Alta \\
\hline II & Alta & II & Alta & Alta \\
\hline
\end{tabular}

Conforme citado anteriormente, dentre os PSFs do Grupo de PSFs Fatores de Stress Fisiológicos, apenas Fome ou Sede, e Interrupção do Ritmo Circadiano provocam influência direta sobre esta etapa.

\begin{tabular}{|c|c|c|c|c|}
\hline $\begin{array}{c}\text { Exercício Físico } \\
\text { Fadiga }\end{array}$ & Ind. & $\begin{array}{c}\text { Fome ou Sede } \\
\text { Interrupção do Ritmo } \\
\text { Circadiano }\end{array}$ & Baixa & Baixa \\
\hline II & Ind. & II & Média & M édia \\
\hline II & Ind. & II & Alta & Alta \\
\hline
\end{tabular}




\begin{tabular}{|c|c|c|c|c|}
\hline $\begin{array}{l}\text { Ameaças (de Falha, de } \\
\text { Perda do Emprego, etc.) } \\
\text { Falta de Recompensas, } \\
\text { Reconhecimento e } \\
\text { Benefícios } \\
\text { Motivos Conflitantes sobre } \\
\text { o Desempenho no Trabalho }\end{array}$ & Baixa & $\begin{array}{l}\text { Carga Pesada de } \\
\text { Informações } \\
\text { Início Inesperado do Stress }\end{array}$ & Baixa & Baixa \\
\hline II & Baixa & II & Média & Baixa \\
\hline II & Baixa & II & Alta & Média \\
\hline II & Média & II & Baixa & Baixa \\
\hline II & Média & II & Média & Média \\
\hline II & Média & II & Alta & Alta \\
\hline II & Alta & II & Baixa & Média \\
\hline II & Alta & II & Média & Alta \\
\hline II & Alta & II & Alta & Alta \\
\hline
\end{tabular}

\begin{tabular}{|c|c|c|c|c|}
\hline Reforço Negativo & Baixa & $\begin{array}{c}\text { Períodos de Vigilância } \\
\text { Longos, sem } \\
\text { Acontecimentos } \\
\text { Trabalho Monótono, } \\
\text { Degradante ou Sem } \\
\text { Sentido }\end{array}$ & Baixa & Baixa \\
\hline II Inconsistentes & Baixa & II & Média & Baixa \\
\hline II & Baixa & II & Alta & M édia \\
\hline II & Média & II & Baixa & M édia \\
\hline II & Média & II & Média & Média \\
\hline II & Média & II & Alta & Alta \\
\hline II & Alta & II & Baixa & Média \\
\hline II & Alta & II & Média & Alta \\
\hline II & Alta & II & Alta & Alta \\
\hline
\end{tabular}

\begin{tabular}{|c|c|c|c|c|}
\hline $\begin{array}{c}\text { Ações desenvolvidas por } \\
\text { Supervisores, Colegas, } \\
\text { Representantes de } \\
\begin{array}{c}\text { Sindicatos, e Pessoal de } \\
\text { Regulamentação }\end{array}\end{array}$ & Baixa & Estrutura de Equipe & Baixa & Baixa \\
\hline II & Baixa & II & Média & Baixa \\
\hline$I I$ & Baixa & II & Alta & M édia \\
\hline$I I$ & Média & II & Baixa & Baixa \\
\hline$I I$ & Média & II & Média & M édia \\
\hline$I I$ & Média & II & Alta & Alta \\
\hline$I I$ & Alta & II & Baixa & M édia \\
\hline$I I$ & Alta & II & Média & Alta \\
\hline$I I$ & Alta & II & Alta & Alta \\
\hline
\end{tabular}


Como já explicado no sub-item anterior, os PSFs aqui analisados são de suma importância para esta etapa.

\begin{tabular}{|c|c|c|c|c|}
\hline Métodos de Trabalho & Baixa & $\begin{array}{c}\text { Feedback (Conhecimento } \\
\text { de Resultados) } \\
\text { Procedimentos (Escritos ou } \\
\text { Não Escritos) }\end{array}$ & Baixa & Baixa \\
\hline II & Baixa & II & Média & Baixa \\
\hline II & Baixa & II & Alta & M édia \\
\hline II & Média & II & Baixa & Baixa \\
\hline II & Média & II & Média & M édia \\
\hline II & Média & II & Alta & Alta \\
\hline II & Alta & II & Baixa & M édia \\
\hline II & Alta & II & Média & Alta \\
\hline II & Alta & II & Alta & Alta \\
\hline
\end{tabular}

Se a Motivação bem como a Tensão Mental estiverem indicando Alta possibilidade de erro de Decisão, é muito provável que de fato ocorrerá o erro: o aproveitamento da informação obtida na etapa anterior será baixíssimo, prejudicado/intensificado negativamente pela falta de vontade (Motivação Baixa) e pela falta de capacidade (Tensão Mental) de decidir.

\begin{tabular}{|c|c|c|c|c|}
\hline $\begin{array}{c}\text { Condição Física/Saúde } \\
\text { Influência de outros } \\
\text { agentes externos (pessoas, } \\
\text { família) }\end{array}$ & Baixa & Motivação & Baixa & Baixa \\
\hline II & Baixa & II & Média & M édia \\
\hline II & $*$ & II & Alta & Alta \\
\hline II & Média & II & Baixa & Baixa \\
\hline II & Média & II & Média & M édia \\
\hline II & Alta & II & Baixa & M édia \\
\hline II & Alta & II & Média & Alta \\
\hline
\end{tabular}

Para melhor exibir as regras do SIF seguinte, o mesmo foi separado em três. Caso o SIF do primeiro nível que engloba Conhecimento de Padrões de Desempenho, e Experiência esteja indicando Baixa possibilidade de erro de Decisão: 


\begin{tabular}{|c|c|c|c|c|}
\hline $\begin{array}{l}\text { Nível de cultura de } \\
\text { segurança } \\
\text { Nível de cultura } \\
\text { organizacional }\end{array}$ & Baixa & $\begin{array}{l}\text { Nível de práticas } \\
\text { Qualidade do Treinamento }\end{array}$ & Baixa & Baixa \\
\hline II & Baixa & II & Média & Baixa \\
\hline II & Baixa & II & Alta & Baixa \\
\hline II & Média & II & Baixa & Baixa \\
\hline II & Média & II & Média & Média \\
\hline II & Média & II & Alta & Média \\
\hline II & Alta & II & Baixa & Média \\
\hline II & Alta & II & Média & Média \\
\hline II & Alta & II & Alta & Alta \\
\hline
\end{tabular}

Caso Conhecimento de Padrões de Desempenho, e Experiência estejam indicando Média possibilidade de erro de Decisão:

\begin{tabular}{|c|c|c|c|c|}
\hline $\begin{array}{c}\text { Nível de cultura de } \\
\text { segurança } \\
\text { Nível de cultura } \\
\text { organizacional }\end{array}$ & Baixa & $\begin{array}{c}\text { Nível de práticas } \\
\text { Qualidade do Treinamento }\end{array}$ & Baixa & Baixa \\
\hline II & Baixa & II & Média & Média \\
\hline II & Baixa & II & Alta & Média \\
\hline II & Média & II & Baixa & Média \\
\hline II & Média & II & Média & Média \\
\hline II & Média & II & Alta & Alta \\
\hline II & Alta & II & Baixa & Média \\
\hline II & Alta & II & Média & Alta \\
\hline II & Alta & II & Alta & Alta \\
\hline
\end{tabular}

E caso estejam indicando Alta possibilidade de erro de Decisão:

Uma situação interessante prevista por esse SIF é a de o sub-grupo dos PSFs Nível de Cultura de Segurança e Nível de Cultura Organizacional ser o único a indicar Baixa possibilidade de falha enquanto os demais indicam alta. Significa que, por mais que o funcionário esteja consciente da segurança e da organização, não tem experiência, treinamento ou prática suficiente para planejar a maneira correta para agir na etapa seguinte. 


\begin{tabular}{|c|c|c|c|c|}
\hline $\begin{array}{c}\text { Nível de cultura de } \\
\text { segurança } \\
\text { Nível de cultura } \\
\text { organizacional }\end{array}$ & Baixa & $\begin{array}{c}\text { Nível de práticas } \\
\text { Qualidade do Treinamento }\end{array}$ & Baixa & Baixa \\
\hline$I$ & Baixa & $\|$ & Média & M édia \\
\hline$I I$ & Baixa & $\|$ & Alta & Alta \\
\hline$I I$ & Média & $\|$ & Baixa & M édia \\
\hline$I I$ & Média & $\|$ & Média & Alta \\
\hline$I I$ & Média & $\|$ & Alta & Alta \\
\hline$I I$ & Alta & $\|$ & Baixa & Alta \\
\hline$I I$ & Alta & $\|$ & Média & Alta \\
\hline$I I$ & Alta & $\|$ & Alta & Alta \\
\hline
\end{tabular}

\subsubsection{3.}

\section{SIFs Hierárquicos do Terceiro Nível}

\begin{tabular}{|c|c|c|c|c|}
\hline $\begin{array}{c}\text { Se possibilidade de erro } \\
\text { de Informação do Sub- } \\
\text { grupo }\end{array}$ & é & $\begin{array}{l}\text { e possibilidade de erro de } \\
\text { Informação do Sub-grupo }\end{array}$ & é & $\begin{array}{c}\text { Então } \\
\text { possibilidade } \\
\text { de erro de } \\
\text { Decisão é }\end{array}$ \\
\hline $\begin{array}{l}\text { Ameaças (de Falha, de } \\
\text { Perda do Emprego, etc.) } \\
\text { Falta de Recompensas, } \\
\text { Reconhecimento e } \\
\text { Benefícios } \\
\text { M otivos Conflitantes } \\
\text { sobre o Desempenho no } \\
\text { Trabalho } \\
\text { Carga Pesada de } \\
\text { Informações } \\
\text { Início Inesperado do } \\
\text { Stress }\end{array}$ & Baixa & $\begin{array}{l}\text { Ações desenvolvidas por } \\
\text { Supervisores, Colegas, } \\
\text { Representantes de } \\
\text { Sindicatos, e Pessoal de } \\
\text { Regulamentação } \\
\text { Comunicação } \\
\text { Estrutura de Equipe } \\
\text { Estrutura Organizacional }\end{array}$ & Baixa & Baixa \\
\hline II & Baixa & II & Média & Baixa \\
\hline II & Baixa & II & Alta & Média \\
\hline II & Média & II & Baixa & Baixa \\
\hline II & Média & II & Média & Média \\
\hline II & Média & II & Alta & Alta \\
\hline II & Alta & II & Baixa & Média \\
\hline II & Alta & II & Média & Alta \\
\hline II & Alta & II & Alta & Alta \\
\hline
\end{tabular}


Estes PSFs são de suma importância, constituem a base da Decisão, por isso, qualquer um deles que esteja ruim, resultará num erro de decisão, ainda que outros PSFs estejam razoáveis.

\begin{tabular}{|c|c|c|c|c|}
\hline $\begin{array}{c}\text { Capacidade Analítica } \\
\text { Capacidade de } \\
\text { Classificação } \\
\text { Capacidade de Antecipação } \\
\text { Capacidade de Tomada de } \\
\text { Decisões }\end{array}$ & Baixa & $\begin{array}{c}\text { Inteligência numérica } \\
\text { (capacidade de cálculos) } \\
\text { Percepção de séries } \\
\text { Memória } \\
\text { Predisposição para novos } \\
\text { conhecimentos }\end{array}$ & Baixa & Baixa \\
\hline II & Baixa & II & Média & Média \\
\hline II & Baixa & II & Alta & Alta \\
\hline II & Média & II & Baixa & Média \\
\hline II & Média & II & Média & Média \\
\hline II & Média & II & Alta & Alta \\
\hline II & Alta & II & Baixa & Alta \\
\hline II & Alta & II & Média & Alta \\
\hline II & Alta & II & Alta & Alta \\
\hline
\end{tabular}

Os PSFs do sub-grupo que contém o PSF Procedimentos possuem maior influência na Decisão, é citado na literatura (Hendrickson, 2010) que ocasionalmente um funcionário pode fazer uso de fatores externos como instrumentos e procedimentos, porém ter conhecimento das políticas da planta e dos métodos de trabalho, bem como ter um bom feedback é mais importante. $\mathrm{O}$ SIF que engloba tais PSFs também contém o PSF Qualidade do Ambiente, porém este é indiferente para a Decisão.

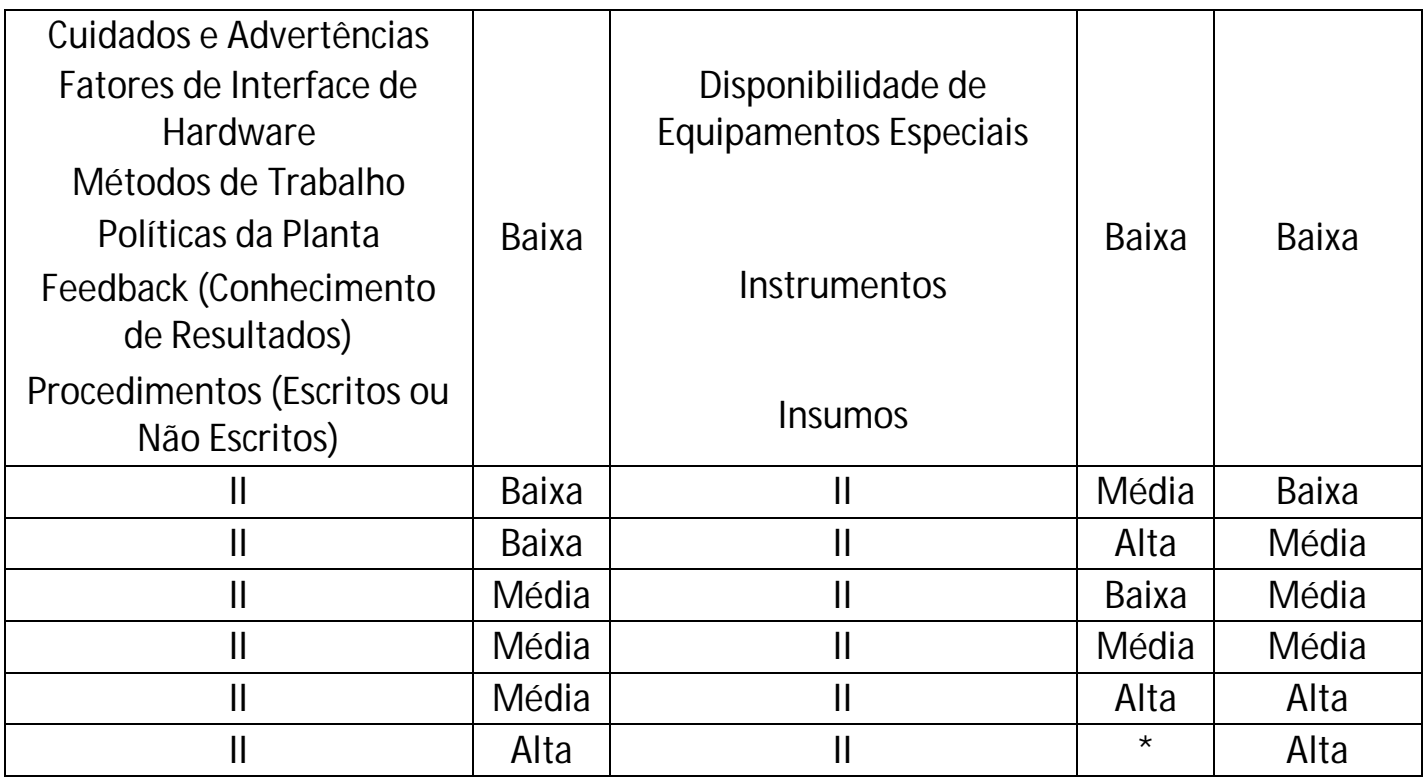


O SIF abaixo também contém o PSF Trabalho em Alturas, porém este só é pertinente para a etapa de Ação.

\begin{tabular}{|c|c|c|c|c|}
\hline $\begin{array}{c}\text { Exercício Físico } \\
\text { Fadiga } \\
\text { Fome ou Sede } \\
\text { Interrupção do Ritmo } \\
\text { Circadiano }\end{array}$ & Baixa & $\begin{array}{c}\text { Distrações (devido a Ruído, } \\
\text { Clarão, M ovimentos, etc.) } \\
\text { Perda de Sensibilidade }\end{array}$ & Baixa & Baixa \\
\hline II & Baixa & II & Média & Média \\
\hline II & Baixa & II & Alta & Média \\
\hline II & Média & II & Baixa & Baixa \\
\hline II & Média & II & Média & Média \\
\hline II & Média & II & Alta & Alta \\
\hline II & Alta & II & Baixa & Média \\
\hline II & Alta & II & Média & Média \\
\hline II & Alta & II & Alta & Alta \\
\hline
\end{tabular}

Capacidade Crítica da Tarefa, e Complexidade da Tarefa (Carga de Informações) são bastante influentes nesta etapa, enquanto Quantidade de Pessoal, e Rodízio de Turnos são indiferentes.

\begin{tabular}{|c|c|c|c|c|}
\hline $\begin{array}{c}\text { Capacidade Crítica da } \\
\text { Tarefa }\end{array}$ & Baixa & $\begin{array}{c}\text { Freqüência e } \\
\text { Repetitividade da Tarefa } \\
\text { Horas de Trabalho / } \\
\text { Intervalos de Trabalho } \\
\text { (Carga de Informaçõos) } \\
\text { Rodízio de Turnos }\end{array}$ & Baixa & Baixa \\
\hline II & Baixa & II & Média & Baixa \\
\hline II & Baixa & II & Alta & M édia \\
\hline II & Média & II & Baixa & M édia \\
\hline II & Média & II & Média & M édia \\
\hline II & Média & II & Alta & Alta \\
\hline II & Alta & II & Baixa & Alta \\
\hline II & Alta & II & Média & Alta \\
\hline II & Alta & II & Alta & Alta \\
\hline
\end{tabular}

Este SIF de terceiro nível é interessante e muito importante para a Decisão, em uma variável de entrada tem-se a vontade de realizar a tarefa de maneira polida, correta, eficiente; e de outro tem-se o conhecimento das diferentes e melhores maneiras de executá-la. Se ambos estão positivos o erro não ocorrerá, contudo, se um deles estiver fraco, o outro sub-grupo não terá sua capacidade aproveitada: por mais que o funcionário tenha o conhecimento, estará sem 
vontade de planejar a execução da tarefa com apreço (essa mesma situação se intensificará quando estes grupos se juntarem ao sub-grupo que contém o PSF Memória). Da mesma forma que, se o funcionário tem vontade de planejar a execução da tarefa da melhor maneira possível, será impedido de fazê-lo caso não possua o conhecimento necessário, seja por ter tido um treinamento precário ou por não conhecer a cultura de segurança e nem a organizacional da empresa.

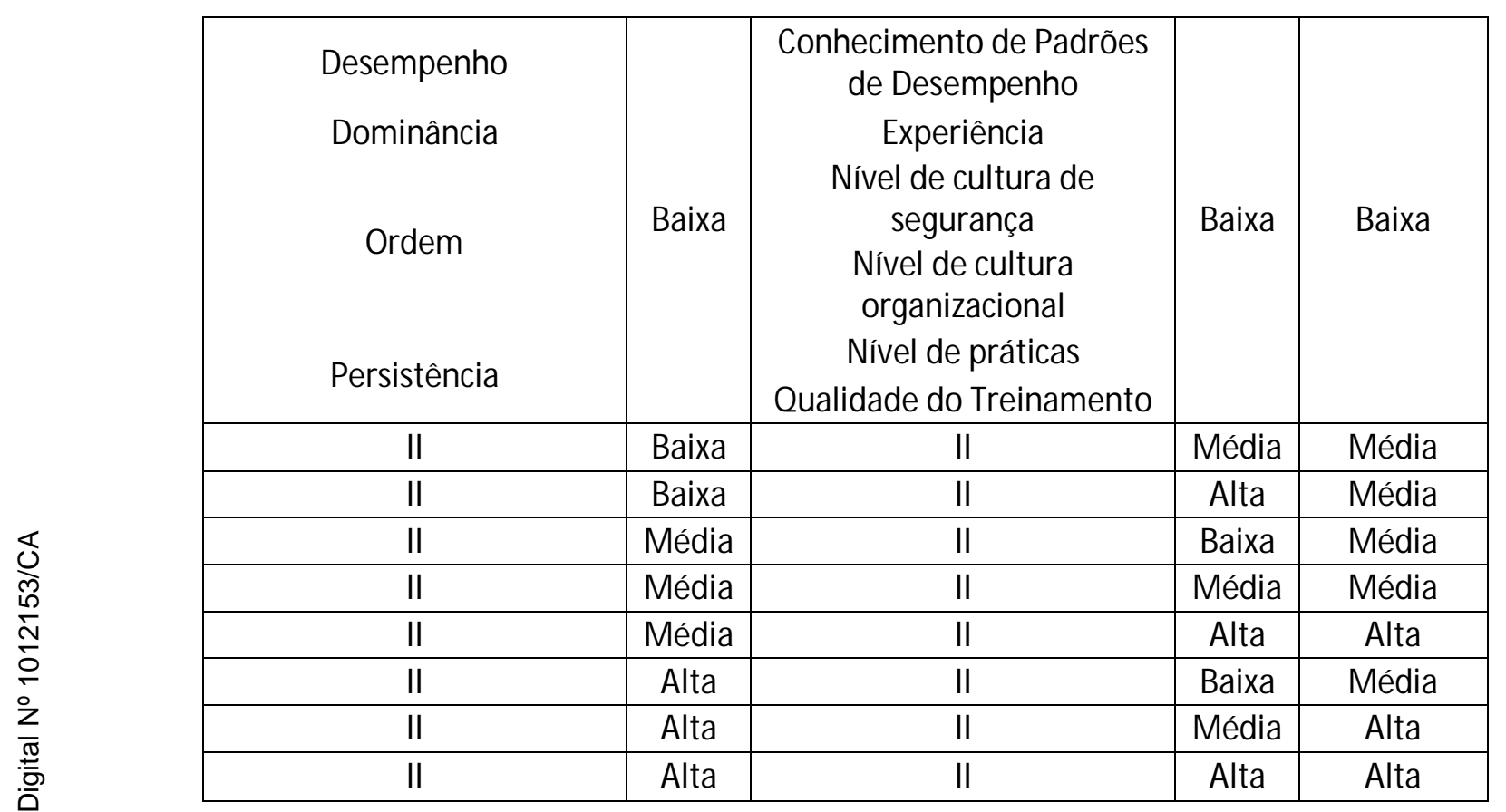

Vale lembrar que para a Denegação estar indicando que a possibilidade de erro de Decisão é Alta, é por que a Denegação está Alta, ou seja ruim. Não confundir a informação contida nessas regras com o "comportamento do PSF no funcionário".

A regra "Se 'Condição Física/Saúde; Influência de outros agentes externos (pessoas, família); Motivação; e Tensão Mental ou Física' tem Baixa possibilidade de erro de Decisão parcial e 'Denegação' tem Alta possibilidade de erro de Decisão parcial então possibilidade de erro de Decisão é Média" é incoerente do ponto de vista de aplicação real. Matematicamente pode ser analisada, mas na prática é irreal. Não faz sentido ter Tensão Mental, e Motivação Baixas enquanto a Denegação está Alta. Isto ocorre por que se a pessoa está manifestando problemas em reconhecer ou admitir sua opinião previamente exposta, é esperado que ela sinta certa "pressão" psicológica e se deixe abalar por este nervosismo 


\begin{tabular}{|c|c|c|c|c|}
\hline $\begin{array}{c}\text { Condição Física/Saúde } \\
\text { Influência de outros } \\
\text { agentes externos } \\
\text { (pessoas, família) } \\
\text { M otivação } \\
\text { Tensão M ental ou Física }\end{array}$ & Baixa & Denegação & Baixa & Baixa \\
\hline II & Baixa & Denegação & Média & Baixa \\
\hline II & Baixa & Denegação & Alta & M édia \\
\hline II & Média & Denegação & Baixa & M édia \\
\hline II & Média & Denegação & Média & M édia \\
\hline II & Média & Denegação & Alta & Alta \\
\hline II & Alta & Denegação & Baixa & Alta \\
\hline II & Alta & Denegação & Média & Alta \\
\hline II & Alta & Denegação & Alta & Alta \\
\hline
\end{tabular}

Estes PSFs são mais influentes durante a etapa de Informação, quando o que será executado está sendo passado de um colaborador para outro, no recebimento da "ordem" ou sugestão. Ainda assim, durante a etapa de Decisão estes fatores tem impacto, negativo ou positivo. A opinião expressada por outra pessoa, influenciará na impressão que o funcionário tem da tarefa que está prestes a realizar. Concomitantemente, a importância dada a tais opiniões será moldada pelos fatores de personalidade do funcionário, e alterarão a maneira como a tarefa será planejada.

\begin{tabular}{|c|c|c|c|c|}
\hline Afago & Baixa & $\begin{array}{c}\text { Períodos de Vigilância } \\
\text { Longos, sem } \\
\text { Acontecimentos } \\
\text { Trabalho M onótono, } \\
\text { Degradante ou Sem } \\
\text { Sentido } \\
\text { Afiliação }\end{array}$ & Baixa & Baixa \\
\hline Agressão & Reforo Negativo \\
Autonomia & Buixa & II & Média & Baixa \\
\hline II & Baixa & II & Alta & M édia \\
\hline II & Média & II & Baixa & Baixa \\
\hline II & Média & II & Média & M édia \\
\hline II & Média & II & Alta & Alta \\
\hline II & Alta & II & Baixa & M édia \\
\hline II & Alta & II & Média & Alta \\
\hline II & Alta & II & Alta & Alta \\
\hline II & & &
\end{tabular}

Os fatores de personalidade avaliados por este SIF versam a respeito da característica intrínseca ao funcionário de apoiar demais colegas de trabalho, seja ao dar crédito por ajuda recebida, ou reconhecer em que momento deve manifestar 
uma opinião própria ou não. O PSF Mudança tem influência direta sobre estes, pois engloba o desejo de alterar decisões anteriores, sendo identificado pela pouca ligação a lugares ou pessoas por parte do funcionário.

\begin{tabular}{|c|c|c|c|c|}
\hline $\begin{array}{c}\text { Assistência } \\
\text { Deferência } \\
\text { Exibição } \\
\text { Intracepção }\end{array}$ & Baixa & Mudança & Baixa & Baixa \\
\hline II & Baixa & Mudança & Média & Baixa \\
\hline II & Baixa & Mudança & Alta & M édia \\
\hline II & Média & Mudança & Baixa & Baixa \\
\hline II & M édia & Mudança & Média & Média \\
\hline II & M édia & Mudança & Alta & Alta \\
\hline II & Alta & Mudança & Baixa & Média \\
\hline II & Alta & Mudança & Média & Alta \\
\hline II & Alta & Mudança & Alta & Alta \\
\hline
\end{tabular}

3.4.2.4.

\section{SIFs Hierárquicos do Quarto Nível}

Os PSFs Constrição de Movimentos, Dor ou Desconforto, Longa Duração do Stress, Repetição de Movimentos, e Alta Velocidade na Execução da Tarefa são indiferentes para a Decisão.

\begin{tabular}{|c|c|c|c|c|}
\hline $\begin{array}{c}\text { Se possibilidade de erro } \\
\text { de Informação do Sub- } \\
\text { grupo }\end{array}$ & é & $\begin{array}{c}\text { Então } \\
\text { e possibilidade de erro de } \\
\text { Informação do Sub-grupo } \\
\text { Dor ou Desconforto }\end{array}$ & é & $\begin{array}{c}\text { possibilidade } \\
\text { de erro de } \\
\text { Decisão é }\end{array}$ \\
\hline $\begin{array}{c}\text { Constrição de M ovimentos } \\
\text { Repetição de Movimentos }\end{array}$ & Ind. & $\begin{array}{c}\text { Capacidade Crítica da } \\
\text { Tarefa } \\
\text { Complexidade da Tarefa } \\
\text { (Carga de Informações) } \\
\text { Freqüência e } \\
\text { Repetitividade da Tarefa } \\
\text { Horas de Trabalho / } \\
\text { Intervalos de Trabalho } \\
\text { Quantidade de Pessoal } \\
\text { Rodízio de Turnos }\end{array}$ & Baixa & Baixa \\
\hline Execução da Tarefa & Ind. & II & M édia & M édia \\
\hline II & Ind. & Il & Alta \\
\hline II & & \multicolumn{2}{|c|}{} \\
\hline
\end{tabular}

Os PSFs do SIF abaixo são mais influentes na etapa anterior (Informação) porém ainda exercem influência na Decisão, no que diz respeito à capacidade do 
funcionário de considerar os demais no momento em que planeja suas próprias Ações futuras.

Como se tratam de três variáveis de entrada, as regras foram divididas em três, para facilitar sua exposição e entendimento. Caso o resultado parcial do SIF de segundo nível que considera os PSFs Ameaças (de Falha, de Perda do Emprego, etc.); Falta de Recompensas, Reconhecimento e Benefícios; Motivos Conflitantes sobre o Desempenho no Trabalho; Carga Pesada de Informações; Início Inesperado do Stress; Ações desenvolvidas por Supervisores, Colegas, Representantes de Sindicatos, e Pessoal de Regulamentação; Comunicação; Estrutura de Equipe; e Estrutura Organizacional seja Baixa:

\begin{tabular}{|c|c|c|c|c|}
\hline Identificação com grupos & Baixa & $\begin{array}{c}\text { Afago } \\
\text { Afiliação } \\
\text { Agressão } \\
\text { Autonomia } \\
\text { Períodos de Vigilância } \\
\text { Longos, sem } \\
\text { Acontecimentos } \\
\text { Trabalho M onótono, } \\
\text { Degradante ou Sem } \\
\text { Sentido } \\
\text { Reforço Negativo } \\
\text { Sugestões Inconsistentes }\end{array}$ & Baixa & Baixa \\
\hline II & Baixa & II & Média & Baixa \\
\hline II & Baixa & II & Alta & Média \\
\hline II & Média & II & Baixa & Baixa \\
\hline II & Média & $\|$ & Média & Média \\
\hline II & Média & II & Alta & Média \\
\hline II & Alta & II & Baixa & Baixa \\
\hline II & Alta & II & Média & Média \\
\hline II & Alta & $\|$ & Alta & Alta \\
\hline
\end{tabular}


Caso seja Média:

\begin{tabular}{|c|c|c|c|c|}
\hline Identificação com grupos & Baixa & $\begin{array}{c}\text { Afago / Afiliação / Agressão } \\
\text { / Autonomia / Períodos } \\
\text { sem Acontecimentos / } \\
\text { Trabalho M onótono / } \\
\text { Reforço Negativo / } \\
\text { Sugestões Inconsistentes }\end{array}$ & Baixa & Baixa \\
\hline II & Baixa & II & Média & M édia \\
\hline II & Baixa & II & Alta & Alta \\
\hline II & Média & II & Baixa & M édia \\
\hline II & Média & II & Média & Média \\
\hline II & Média & II & Alta & Alta \\
\hline II & Alta & II & Baixa & M édia \\
\hline II & Alta & II & Média & Alta \\
\hline II & Alta & II & Alta & Alta \\
\hline
\end{tabular}

E caso seja Alta:

\begin{tabular}{|c|c|c|c|c|}
\hline Identificação com grupos & Baixa & $\begin{array}{c}\text { Afago / Afiliação / Agressão } \\
\text { / Autonomia / Períodos } \\
\text { sem Acontecimentos / } \\
\text { Trabalho M onótono / } \\
\text { Reforço Negativo / } \\
\text { Sugestões Inconsistentes }\end{array}$ & Baixa & M édia \\
\hline II & Baixa & II & Média & M édia \\
\hline II & Baixa & II & Alta & Alta \\
\hline II & Média & II & Baixa & Média \\
\hline II & Média & II & Média & Alta \\
\hline II & Média & II & Alta & Alta \\
\hline II & Alta & II & Baixa & Alta \\
\hline II & Alta & II & Média & Alta \\
\hline II & Alta & II & Alta & Alta \\
\hline & \multicolumn{2}{|c}{}
\end{tabular}

Os dois conjuntos de regras abaixo possuem PSFs de grande influência na Decisão, porém a primeira coluna deles contém alguns PSFs já avaliados anteriormente como indiferentes, fazendo com que o "peso" de seu sub-grupo nos SIFs de quarto nível seja menor. 


\begin{tabular}{|c|c|c|c|c|}
\hline $\begin{array}{l}\text { Cuidados e Advertências } \\
\text { Fatores de Interface de } \\
\text { Hardware } \\
\text { M étodos de Trabalho } \\
\text { Políticas da Planta } \\
\text { Feedback (Conhecimento } \\
\text { de Resultados) } \\
\text { Procedimentos (Escritos ou } \\
\text { Não Escritos) } \\
\text { Qualidade do Ambiente }\end{array}$ & Baixa & $\begin{array}{c}\text { Desempenho } \\
\text { Dominância } \\
\text { Ordem } \\
\text { Persistência } \\
\text { Conhecimento de Padrões } \\
\text { de Desempenho } \\
\text { Experiência } \\
\text { Nível de cultura de } \\
\text { segurança } \\
\text { Nível de cultura } \\
\text { organizacional } \\
\text { Nível de práticas } \\
\text { Qualidade do Treinamento }\end{array}$ & Baixa & Baixa \\
\hline II & Baixa & II & Média & Média \\
\hline II & Baixa & II & Alta & Média \\
\hline II & Média & II & Baixa & Baixa \\
\hline II & Média & II & Média & Média \\
\hline II & Média & II & Alta & Alta \\
\hline II & Alta & II & Baixa & Média \\
\hline II & Alta & II & Média & Alta \\
\hline II & Alta & II & Alta & Alta \\
\hline
\end{tabular}

\begin{tabular}{|c|c|c|c|c|}
\hline $\begin{array}{c}\text { Exercício Físico } \\
\text { Fadiga } \\
\text { Fome ou Sede } \\
\text { Interrupção do Ritmo } \\
\text { Circadiano } \\
\text { Distrações (devido a } \\
\text { Ruído, Clarão, } \\
\text { Movimentos, etc.) } \\
\text { Perda de Sensibilidade } \\
\text { Trabalho em Alturas }\end{array}$ & Baixa & $\begin{array}{c}\text { Condição Física/Saúde } \\
\text { Influência de outros agentes } \\
\text { externos (pessoas, família) } \\
\text { M otivação } \\
\text { Tensão M ental ou Física } \\
\text { Denegação }\end{array}$ & Baixa & Baixa \\
\hline II & Baixa & II & Média & Média \\
\hline II & Baixa & II & Alta & Média \\
\hline II & Média & II & Baixa & Baixa \\
\hline II & Média & II & Média & Média \\
\hline II & Média & II & Alta & Alta \\
\hline II & Alta & II & Baixa & Média \\
\hline II & Alta & II & Média & Alta \\
\hline II & Alta & II & Alta & Alta \\
\hline
\end{tabular}




\subsubsection{5.}

\section{SIFs Hierárquicos do Quinto Nível}

No sub-grupo da primeira coluna do SIF abaixo, apenas Capacidade Crítica da Tarefa, Complexidade da Tarefa, Freqüência e Repetitividade da Tarefa; e Intervalos de Trabalho influenciam a Decisão. Porém sua importância é elevada, fazendo com que seu sub-grupo seja tão influente quanto o outro, que possui maior quantidade de PSFs influentes.

\begin{tabular}{|c|c|c|c|c|}
\hline $\begin{array}{c}\text { Se possibilidade de erro } \\
\text { de Informação do Sub- } \\
\text { grupo }\end{array}$ & é & $\begin{array}{l}\text { e possibilidade de erro de } \\
\text { Informação do Sub-grupo }\end{array}$ & é & $\begin{array}{c}\text { Então } \\
\text { possibilidade } \\
\text { de erro de } \\
\text { Decisão é }\end{array}$ \\
\hline $\begin{array}{c}\text { Constrição de } \\
\text { M ovimentos } \\
\text { Dor ou Desconforto } \\
\text { Longa Duração do Stress } \\
\text { Repetição de } \\
\text { M ovimentos } \\
\text { Alta Velocidade na } \\
\text { Execução da Tarefa } \\
\text { Capacidade Crítica da } \\
\text { Tarefa } \\
\text { Complexidade da Tarefa } \\
\text { (Carga de Informações) } \\
\text { Freqüência e } \\
\text { Repetitividade da Tarefa } \\
\text { Horas de Trabalho / } \\
\text { Intervalos de Trabalho } \\
\text { Quantidade de Pessoal } \\
\text { Rodízio de Turnos }\end{array}$ & Baixa & $\begin{array}{c}\text { Exercício Físico } \\
\text { Fadiga } \\
\text { Fome ou Sede } \\
\text { Interrupção do Ritmo } \\
\text { Circadiano } \\
\text { Distrações (devido a Ruído, } \\
\text { Clarão, M ovimentos, etc.) } \\
\text { Perda de Sensibilidade } \\
\text { Trabalho em Alturas } \\
\text { Condição Física/Saúde } \\
\text { Influência de outros agentes } \\
\text { externos (pessoas, família) } \\
\text { M otivação } \\
\text { Tensão M ental ou Física } \\
\text { Denegação }\end{array}$ & Baixa & Baixa \\
\hline II & Baixa & II & Média & Baixa \\
\hline II & Baixa & II & Alta & Média \\
\hline II & Média & II & Baixa & Baixa \\
\hline II & Média & II & Média & Média \\
\hline II & Média & II & Alta & Alta \\
\hline II & Alta & II & Baixa & Média \\
\hline II & Alta & II & Média & Alta \\
\hline II & Alta & II & Alta & Alta \\
\hline
\end{tabular}




\begin{tabular}{|c|c|c|c|c|}
\hline $\begin{array}{c}\text { Cuidados e Advertências } \\
\text { Fatores de Interface de } \\
\text { Hardware } \\
\text { Métodos de Trabalho } \\
\text { Políticas da Planta } \\
\text { Feedback (Conhecimento } \\
\text { de Resultados) } \\
\text { Procedimentos (Escritos ou } \\
\text { Não Escritos) } \\
\text { Qualidade do Ambiente } \\
\text { Desempenho } \\
\text { Dominância } \\
\text { Ordem } \\
\text { Persistência } \\
\text { Conhecimento de Padrões } \\
\text { de Desempenho } \\
\text { Experiência } \\
\text { Nível de cultura de } \\
\text { segurança } \\
\text { Nível de cultura } \\
\text { organizacional } \\
\text { Nível de práticas } \\
\text { Qualidade do Treinamento }\end{array}$ & Baixa & $\begin{array}{c}\text { Continuidade de matrizes } \\
\text { ou conjuntos }\end{array}$ & Baixa & Baixa \\
\hline II & Baixa & II & Média & Baixa \\
\hline II & Baixa & II & Alta & Baixa \\
\hline II & Média & II & Baixa & Média \\
\hline II & Média & II & Média & Média \\
\hline II & Média & II & Alta & Alta \\
\hline II & Alta & II & Baixa & Alta \\
\hline II & Alta & II & Média & Alta \\
\hline II & Alta & II & Alta & Alta \\
\hline
\end{tabular}


Os PSFs abaixo são críticos para esta etapa, principalmente o sub-grupo que contém o PSF Carga Pesada de Informações.

\begin{tabular}{|c|c|c|c|c|}
\hline $\begin{array}{l}\text { Ameaças (de Falha, de } \\
\text { Perda do Emprego, etc.) } \\
\text { Falta de Recompensas, } \\
\text { Reconhecimento e } \\
\text { Benefícios } \\
\text { M otivos Conflitantes sobre } \\
\text { o Desempenho no Trabalho } \\
\text { Carga Pesada de } \\
\text { Informações } \\
\text { Início Inesperado do Stress } \\
\text { Ações desenvolvidas por } \\
\text { Supervisores, Colegas, } \\
\text { Representantes de } \\
\text { Sindicatos, e Pessoal de } \\
\text { Regulamentação } \\
\text { Comunicação } \\
\text { Estrutura de Equipe } \\
\text { Estrutura Organizacional } \\
\text { Identificação com grupos } \\
\text { Afago } \\
\text { Afiliação } \\
\text { Agressão } \\
\text { Autonomia } \\
\text { Períodos de Vigilância } \\
\text { Longos, sem } \\
\text { Acontecimentos } \\
\text { Trabalho M onótono, } \\
\text { Degradante ou Sem Sentido } \\
\text { Reforço Negativo } \\
\text { Sugestões Inconsistentes }\end{array}$ & Baixa & Intracepção & Baixa & Baixa \\
\hline II & Baixa & II & Média & Baixa \\
\hline II & Baixa & II & Alta & Média \\
\hline II & Média & II & Baixa & Média \\
\hline II & Média & II & Média & Média \\
\hline II & Média & II & Alta & Alta \\
\hline II & Alta & II & Baixa & Alta \\
\hline II & Alta & II & Média & Alta \\
\hline II & Alta & II & Alta & Alta \\
\hline
\end{tabular}




\subsubsection{6.}

\section{SIF Hierárquico do Sexto Nível}

Este SIF é determinante para a Decisão, é responsável por associar e avaliar conjuntamente os principais fatores cognitivos com outros fatores internos e externos muito pertinentes à esta etapa.

\begin{tabular}{|c|c|c|c|c|}
\hline $\begin{array}{c}\text { Se possibilidade de erro } \\
\text { de Informação do Sub- } \\
\text { grupo }\end{array}$ & é & $\begin{array}{l}\text { e possibilidade de erro de } \\
\text { Informação do Sub-grupo }\end{array}$ & é & $\begin{array}{c}\text { Então } \\
\text { possibilidade } \\
\text { de erro de } \\
\text { Decisão é }\end{array}$ \\
\hline $\begin{array}{c}\text { Cuidados / Fatores de } \\
\text { Interface / M étodos de } \\
\text { Trabalho / Políticas da } \\
\text { Planta / Feedback / } \\
\text { Procedimentos / } \\
\text { Qualidade do Ambiente / } \\
\text { Desempenho / } \\
\text { Dominância / Ordem / } \\
\text { Persistência / } \\
\text { Conhecimento de Padrões } \\
\text { / Experiência / Cultura de } \\
\text { segurança / Cultura } \\
\text { organizacional / Práticas / } \\
\text { Qualidade do } \\
\text { Treinamento / } \\
\text { Continuidade de matrizes } \\
\text { ou conjuntos / } \\
\text { Estruturação do campo } \\
\text { perceptivo (topologia) }\end{array}$ & Baixa & $\begin{array}{c}\text { Capacidade de Classificação } \\
\text { Capacidade de Antecipação } \\
\text { Capacidade de Tomada de } \\
\text { Decisões } \\
\text { Inteligência numérica } \\
\text { (capacidade de cálculos) } \\
\text { Percepção de séries } \\
\text { Memória } \\
\text { Predisposição para novos } \\
\text { conhecimentos }\end{array}$ & Baixa & Baixa \\
\hline II & Baixa & II & Média & Média \\
\hline II & Baixa & II & Alta & Alta \\
\hline$\|$ & Média & II & Baixa & Média \\
\hline II & Média & II & Média & Média \\
\hline II & Média & II & Alta & Alta \\
\hline II & Alta & II & Baixa & Média \\
\hline II & Alta & II & Média & Alta \\
\hline II & Alta & II & Alta & Alta \\
\hline
\end{tabular}

\subsubsection{7.}

\section{SIF Hierárquico do Sétimo Nível}

Embora o conjunto da direita possua os PSFs Carga Pesada de Informações, Motivos Conflitantes sobre o Desempenho no Trabalho, Início Inesperado do Stress, Reforço Negativo, e Sugestões Inconsistentes, o da esquerda é o que possui PSFs mais pertinentes à Decisão (como Capacidade Analítica, Capacidade 
de Classificação, Capacidade de Tomada de Decisões, e Memória). Sendo assim, o conjunto da esquerda é responsável por modelar como o funcionário irá se comportar diante das situações adversas representadas pelos PSFs do Grupo de PSFs Fatores Externos.

\begin{tabular}{|c|c|c|c|c|}
\hline $\begin{array}{c}\text { Se possibilidade de erro } \\
\text { de Informação do Sub- } \\
\text { grupo }\end{array}$ & é & $\begin{array}{l}\text { e possibilidade de erro de } \\
\text { Informação do Sub-grupo }\end{array}$ & é & $\begin{array}{c}\text { Então } \\
\text { possibilidade } \\
\text { de erro de } \\
\text { Decisão é }\end{array}$ \\
\hline $\begin{array}{c}\text { Cuidados / Fatores de } \\
\text { Interface / Métodos de } \\
\text { Trabalho / Políticas da } \\
\text { Planta / Feedback / } \\
\text { Procedimentos / } \\
\text { Qualidade do Ambiente / } \\
\text { Desempenho / } \\
\text { Dominância / Ordem / } \\
\text { Persistência / } \\
\text { Conhecimento de Padrões } \\
\text { / Experiência / Cultura de } \\
\text { segurança / Cultura } \\
\text { organizacional / Práticas / } \\
\text { Qualidade do } \\
\text { Treinamento / } \\
\text { Continuidade de matrizes } \\
\text { ou conjuntos / } \\
\text { Estruturação do campo } \\
\text { perceptivo (topologia) / } \\
\text { Capacidade Analítica / } \\
\text { Capacidade de } \\
\text { Classificação / Capacidade } \\
\text { de Antecipação / } \\
\text { Capacidade de Tomada } \\
\text { de Decisões / Inteligência } \\
\text { numérica / Percepção de } \\
\text { séries / M emória / } \\
\text { Predisposição para novos } \\
\text { conhecimentos }\end{array}$ & Baixa & $\begin{array}{c}\text { Ameaças / Falta de } \\
\text { Reconhecimento / } \\
\text { Motivos Conflitantes / } \\
\text { Carga Pesada de } \\
\text { Informações / Início } \\
\text { Inesperado do Stress / } \\
\text { Ações desenvolvidas por } \\
\text { Sup. / Comunicação / } \\
\text { Estrutura de Equipe } \\
\text { Estrutura Organizacional / } \\
\text { Identificação com grupos } \\
\text { / Afago / Afiliação / } \\
\text { Agressão / Autonomia / } \\
\text { Períodos sem } \\
\text { Acontecimentos / } \\
\text { Trabalho M onótono / } \\
\text { Reforço Negativo / } \\
\text { Sugestões Inconsistentes / } \\
\text { Assistência / Deferência / } \\
\text { Mudança }\end{array}$ & Baixa & Baixa \\
\hline II & Baixa & II & Média & Baixa \\
\hline II & Baixa & II & Alta & Média \\
\hline II & Média & II & Baixa & M édia \\
\hline II & Média & II & Média & Média \\
\hline II & Média & II & Alta & Alta \\
\hline II & Alta & II & Baixa & Alta \\
\hline II & Alta & II & Média & Alta \\
\hline II & Alta & II & Alta & Alta \\
\hline
\end{tabular}




\subsubsection{8.}

\section{SIF Hierárquico do Oitavo Nível}

A partir do que já foi explicado anteriormente, o sub-grupo aqui representante dos PSFs internos, cognitivos e de personalidade influenciam a Decisão com maior peso.

\begin{tabular}{|c|c|c|c|c|}
\hline $\begin{array}{c}\text { Se possibilidade de erro } \\
\text { de Informação do Sub- } \\
\text { grupo }\end{array}$ & é & $\begin{array}{c}\text { e possibilidade de erro } \\
\text { de Informação do Sub- } \\
\text { grupo }\end{array}$ & é & $\begin{array}{c}\text { Então } \\
\text { possibilidade } \\
\text { de erro de } \\
\text { Decisão é }\end{array}$ \\
\hline 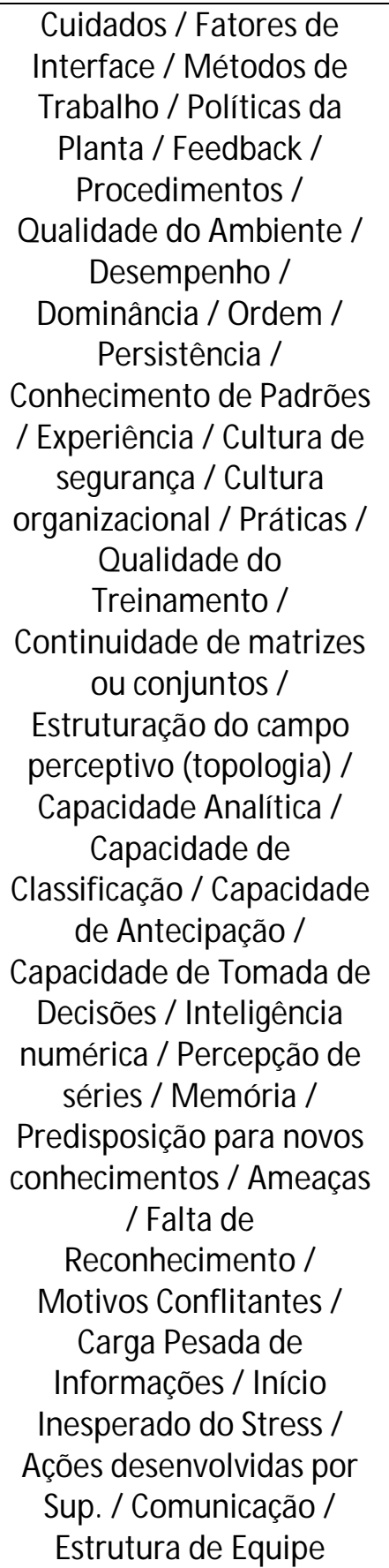 & Baixa & $\begin{array}{l} \\
\\
\text { Constrição de } \\
\text { Movimentos / Dor ou } \\
\text { Desconforto / Longa } \\
\text { duração do Stress / } \\
\text { Repetição de M ov. / Alta } \\
\text { Velocidade na Execução / } \\
\text { Capacidade Crítica / } \\
\text { Complexidade / } \\
\text { Repetitividade / } \\
\text { Intervalos / Quantidade } \\
\text { de Pessoal / Turnos / } \\
\text { Exercício Físico / Fadiga / } \\
\text { Fome ou Sede / Int. Ritmo } \\
\text { Circ. / Distrações / Perda } \\
\text { de Sensibilidade / } \\
\text { Trabalho em Alturas / } \\
\text { Condição Física/ Saúde / } \\
\text { Agentes externos / } \\
\text { M otivação / Tensão } \\
\text { M ental ou Física / } \\
\text { Denegação }\end{array}$ & Baixa & Baixa \\
\hline
\end{tabular}




\begin{tabular}{|c|c|c|c|c|}
\hline $\begin{array}{c}\text { Estrutura Organizacional / } \\
\text { Identificação com grupos / } \\
\text { Afago / Afiliação / } \\
\text { Agressão / Autonomia / } \\
\text { Períodos sem } \\
\text { Acontecimentos / } \\
\text { Trabalho M onótono / } \\
\begin{array}{c}\text { Reforço Negativo / } \\
\text { Sugestões Inconsistentes / } \\
\text { Assistência / Deferência / } \\
\text { Mudança }\end{array}\end{array}$ & & & & \\
& & & & \\
\hline II & & & & \\
\hline II & Baixa & II & & \\
\hline II & Baixa & II & Média & Baixa \\
\hline II & Média & II & Baixa \\
\hline II & Média & II & Baixa & M édia \\
\hline II édia & M édia \\
\hline & Média & II & Alta & Alta \\
\hline & Alta & II & $*$ & Alta \\
\hline
\end{tabular}

\subsubsection{9.}

\section{SIF Hierárquico do Nono Nível}

Novamente, o PSF Nível de Atenção é de extrema importância nesta etapa, bem como em qualquer outra, por ser capaz de praticamente anular qualquer capacidade ou desempenho positivo de outros PSFs. Por outro lado, o bom desempenho desta variável de entrada neste último SIF hierárquico não garante por si só o sucesso da tarefa no quesito Decisão. Ele funciona apenas como um fator de quão eficiente será o aproveitamento dos demais PSFs. Isto significa que se os principais PSFs pertinentes à Decisão estiverem com ótimo desempenho, a falta de atenção terá seu impacto reduzido, ainda que não extinguido.

\begin{tabular}{|c|c|c|c|c|}
\hline Demais PSFs & Baixa & Nível de Atenção & Baixa & Baixa \\
\hline Demais PSFs & Baixa & Nível de Atenção & Média & Baixa \\
\hline Demais PSFs & Baixa & Nível de Atenção & Alta & M édia \\
\hline Demais PSFs & Média & Nível de Atenção & Baixa & M édia \\
\hline Demais PSFs & Média & Nível de Atenção & Média & M édia \\
\hline Demais PSFs & Média & Nível de Atenção & Alta & Alta \\
\hline Demais PSFs & Alta & Nível de Atenção & $*$ & Alta \\
\hline
\end{tabular}




\subsection{3.}

\section{Etapa Ação}

A etapa Ação é externa ao funcionário, é o momento no qual o funcionário de fato realiza a tarefa. É feita colocando em prática todo e qualquer planejamento confeccionado na etapa anterior (Decisão).

Da mesma maneira que ocorre na etapa de Decisão ao assumir que a Informação coletada estava correta, neste momento é considerado que a etapa anterior não apresentou erro. $\mathrm{O}$ objetivo que se espera alcançar ao fazer essa suposição é exclusivamente isolar o cálculo de possibilidade de erros, para ser permitido a atribuição à etapa correta. Portanto, caso exista possibilidades de erros significativas nas etapas anteriores, estas também serão calculadas e indicadas separadamente. Assim, um erro de planejamento que venha a causar um erro de Ação será considerado indireto e atribuído à etapa de Decisão. Nesta etapa de Ação busca se avaliar apenas erros de deslizes e lapsos.

Durante esta etapa, os PSFs do Grupo de PSFs Fatores de Stress Fisiológicos Constrição de Movimentos, Dor ou Desconforto, Exercício Físico, Fadiga, Longa Duração do Stress, e Repetição de Movimentos, que não exercem influência direta nas demais, passam a ser de suma importância.

Os PSFs Cuidados e Advertências, Fatores de Interface de Hardware, Quantidade de Pessoal, e Rodízio de Turnos pertencentes ao Grupo de PSFs Fatores Externos são críticos durante a Ação para o sucesso da tarefa, embora tidos como indiferentes nas duas primeiras etapas. Isso ocorre pois são fatores que se manifestam apenas neste momento, de prática efetiva.

Alguns PSFs do Grupo de PSFs Fatores de Personalidade são indiferentes para esta etapa pois , a saber: Agressão, Autonomia, Assistência, e Deferência.

As regras para o tipo de erro Ação são exibidas a seguir.

\subsubsection{1.}

\section{SIFs Hierárquicos do Primeiro Nível}

Se as tarefas avaliadas forem exclusivamente operacionais, isto é, demandem apenas mão-de-obra e execução de movimentos, a maioria dos PSFs seriam dispensáveis para a etapa Ação. Porém, a análise feita de quais PSFs são relevantes para a tarefa é abordada no Capítulo 4, quando o estudo de caso é 
levado em consideração. Para tarefas "de escritório", as quais demandam explicitamente fatores cognitivos e de personalidade, a grande maioria dos PSFs são influentes nesta fase.

A etapa Decisão utiliza os fatores cognitivos para o planejamento sendo ativados no momento em que o funcionário pensa quais questões são relevantes e como o problema deverá ser abordado o mais eficientemente possível. Na etapa de Ação se a tarefa for intelectual, como por exemplo: "decidir quais documentos devem ser liberados", ou "informar aos responsáveis das instalações autuadas quais medidas tomar", então os fatores cognitivos também são altamente demandados no momento da execução da tarefa. A diferença reside em se planejar previamente à realização da tarefa (Decisão), e efetivamente raciocinar e realizar ações diante de uma situação conforme ela se desenvolve (Ação).

\begin{tabular}{|c|c|c|c|c|}
\hline Se & é & e & é & $\begin{array}{c}\text { Então } \\
\text { possibilidade } \\
\text { de erro de } \\
\text { Ação é }\end{array}$ \\
\hline Capacidade Analítica & Baixa & $\begin{array}{c}\text { Capacidade de } \\
\text { Classificação }\end{array}$ & $*$ & Alta \\
\hline Capacidade Analítica & $*$ & $\begin{array}{c}\text { Capacidade de } \\
\text { Classificação }\end{array}$ & Baixa & Alta \\
\hline Capacidade Analítica & Média & $\begin{array}{c}\text { Capacidade de } \\
\text { Classificação }\end{array}$ & M édia & M édia \\
\hline Capacidade Analítica & Média & $\begin{array}{c}\text { Capacidade de } \\
\text { Classificação }\end{array}$ & Alta & Baixa \\
\hline Capacidade Analítica & Alta & $\begin{array}{c}\text { Capacidade de } \\
\text { Classificação }\end{array}$ & M édia & Baixa \\
\hline Capacidade Analítica & Alta & $\begin{array}{c}\text { Capacidade de } \\
\text { Classificação }\end{array}$ & Alta & Baixa \\
\hline
\end{tabular}




\begin{tabular}{|l|c|c|c|c|}
\hline Capacidade de Antecipação & Baixa & $\begin{array}{c}\text { Capacidade de Tomada de } \\
\text { Decisões }\end{array}$ & Baixa & Alta \\
\hline Capacidade de Antecipação & Baixa & $\begin{array}{c}\text { Capacidade de Tomada de } \\
\text { Decisões }\end{array}$ & Média & Alta \\
\hline Capacidade de Antecipação & Baixa & $\begin{array}{c}\text { Capacidade de Tomada de } \\
\text { Decisões }\end{array}$ & Alta & Alta \\
\hline Capacidade de Antecipação & Média & $\begin{array}{c}\text { Capacidade de Tomada de } \\
\text { Decisões }\end{array}$ & Baixa & Alta \\
\hline Capacidade de Antecipação & Média & $\begin{array}{c}\text { Capacidade de Tomada de } \\
\text { Decisões }\end{array}$ & Média & Média \\
\hline Capacidade de Antecipação & Média & $\begin{array}{c}\text { Capacidade de Tomada de } \\
\text { Decisões }\end{array}$ & Alta & Baixa \\
\hline Capacidade de Antecipação & Alta & $\begin{array}{c}\text { Capacidade de Tomada de } \\
\text { Decisões }\end{array}$ & Baixa & Alta \\
\hline Capacidade de Antecipação & Alta & $\begin{array}{c}\text { Capacidade de Tomada de } \\
\text { Decisões }\end{array}$ & Média & Baixa \\
\hline Capacidade de Antecipação & Alta & $\begin{array}{c}\text { Capacidade de Tomada de } \\
\text { Decisões }\end{array}$ & Alta & Baixa \\
\hline
\end{tabular}

Estruturação do campo perceptivo (topologia) é um PSF particularmente influente nesta etapa, pois reflete a maneira como o funcionário percebe e interpreta o ambiente ao seu redor, alterando diretamente a maneira como irá efetivamente realizar suas ações, podendo inclusive alterar suas decisões tomadas na etapa anterior.

É constatado que cada uma das três etapas utilizadas neste estudo contém por sua vez as mesmas três como sub-etapas (Hendrickson, 2010). Isto significa que a etapa de Ação pode ser subdividida em Informação da Ação, Decisão da Ação, e Ação da Ação. Apesar de aplicar o estudo aqui desenvolvido para este nível de detalhes seja excessivo, é válido observar que parte do que é decidido na etapa de Decisão pode ser alterado pelo funcionário no momento em que executa sua tarefa, conscientemente ou não.

\begin{tabular}{|c|c|c|c|c|}
\hline $\begin{array}{c}\text { Continuidade de matrizes } \\
\text { ou conjuntos }\end{array}$ & Baixa & $\begin{array}{c}\text { Estruturação do campo } \\
\text { perceptivo (topologia) }\end{array}$ & Baixa & Alta \\
\hline $\begin{array}{c}\text { Continuidade de matrizes } \\
\text { ou conjuntos }\end{array}$ & Baixa & $\begin{array}{c}\text { Estruturação do campo } \\
\text { perceptivo (topologia) }\end{array}$ & Média & M édia \\
\hline $\begin{array}{c}\text { Continuidade de matrizes } \\
\text { ou conjuntos }\end{array}$ & Baixa & $\begin{array}{c}\text { Estruturação do campo } \\
\text { perceptivo (topologia) }\end{array}$ & Alta & Baixa \\
\hline $\begin{array}{c}\text { Continuidade de matrizes } \\
\text { ou conjuntos }\end{array}$ & Média & $\begin{array}{c}\text { Estruturação do campo } \\
\text { perceptivo (topologia) }\end{array}$ & Baixa & Alta \\
\hline $\begin{array}{c}\text { Continuidade de matrizes } \\
\text { ou conjuntos }\end{array}$ & Média & $\begin{array}{c}\text { Estruturação do campo } \\
\text { perceptivo (topologia) }\end{array}$ & Média & M édia \\
\hline
\end{tabular}




\begin{tabular}{|c|c|c|c|c|}
\cline { 5 - 5 } $\begin{array}{c}\text { Continuidade de matrizes } \\
\text { ou conjuntos }\end{array}$ & Média & $\begin{array}{c}\text { Estruturação do campo } \\
\text { perceptivo (topologia) }\end{array}$ & Alta & Baixa \\
\hline $\begin{array}{c}\text { Continuidade de matrizes } \\
\text { ou conjuntos }\end{array}$ & Alta & $\begin{array}{c}\text { Estruturação do campo } \\
\text { perceptivo (topologia) }\end{array}$ & Baixa & Alta \\
\hline $\begin{array}{c}\text { Continuidade de matrizes } \\
\text { ou conjuntos }\end{array}$ & Alta & $\begin{array}{c}\text { Estruturação do campo } \\
\text { perceptivo (topologia) }\end{array}$ & Média & Baixa \\
\hline $\begin{array}{c}\text { Continuidade de matrizes } \\
\text { ou conjuntos }\end{array}$ & Alta & $\begin{array}{c}\text { Estruturação do campo } \\
\text { perceptivo (topologia) }\end{array}$ & Alta & Baixa \\
\hline
\end{tabular}

\begin{tabular}{|c|c|c|c|c|}
\hline $\begin{array}{c}\text { Inteligência numérica } \\
\text { (capacidade de cálculos) }\end{array}$ & Baixa & Percepção de séries & Baixa & Alta \\
\hline $\begin{array}{c}\text { Inteligência numérica } \\
\text { (capacidade de cálculos) }\end{array}$ & Baixa & Percepção de séries & Média & Alta \\
\hline $\begin{array}{c}\text { Inteligência numérica } \\
\text { (capacidade de cálculos) }\end{array}$ & Baixa & Percepção de séries & Alta & M édia \\
\hline $\begin{array}{c}\text { Inteligência numérica } \\
\text { (capacidade de cálculos) }\end{array}$ & Média & Percepção de séries & Baixa & Alta \\
\hline $\begin{array}{c}\text { Inteligência numérica } \\
\text { (capacidade de cálculos) }\end{array}$ & Média & Percepção de séries & Média & Média \\
\hline $\begin{array}{c}\text { Inteligência numérica } \\
\text { (capacidade de cálculos) }\end{array}$ & Média & Percepção de séries & Alta & Baixa \\
\hline $\begin{array}{c}\text { Inteligência numérica } \\
\text { (capacidade de cálculos) }\end{array}$ & Alta & Percepção de séries & Baixa & Média \\
\hline $\begin{array}{c}\text { Inteligência numérica } \\
\text { (capacidade de cálculos) }\end{array}$ & Alta & Percepção de séries & Média & Baixa \\
\hline $\begin{array}{c}\text { Inteligência numérica } \\
\text { (capacidade de cálculos) }\end{array}$ & Alta & Percepção de séries & Alta & Baixa \\
\hline
\end{tabular}

Ainda baseado na questão de que o funcionário permanece raciocinando e redefinindo seu curso de $A c ̧ a \tilde{a} o$ enquanto executa a tarefa, é importante analisar os PSFs que tratam da memória de curto prazo. Estes, se tiverem baixo desempenho durante a execução, poderão culminar em uma falha, já que o funcionário pode apresentar resistência a se adaptar a uma nova situação ou esquecer o que havia planejado em um momento anterior.

\begin{tabular}{|c|c|c|c|c|}
\hline Memória & Baixa & $\begin{array}{c}\text { Predisposição para novos } \\
\text { conhecimentos }\end{array}$ & $*$ & Alta \\
\hline Memória & $*$ & $\begin{array}{c}\text { Predisposição para novos } \\
\text { conhecimentos }\end{array}$ & Baixa & Alta \\
\hline Memória & Média & $\begin{array}{c}\text { Predisposição para novos } \\
\text { conhecimentos }\end{array}$ & Média & M édia \\
\hline Memória & Média & $\begin{array}{c}\text { Predisposição para novos } \\
\text { conhecimentos }\end{array}$ & Alta & Baixa \\
\hline Memória & Alta & $\begin{array}{c}\text { Predisposição para novos } \\
\text { conhecimentos }\end{array}$ & Média & Baixa \\
\hline
\end{tabular}


Os fatores de personalidade abaixo exercem impacto direto sobre a Ação, por serem representativos da capacidade do funcionário de ter e demonstrar consideração aos demais. A falta de apreço pelo trabalho de um colega de equipe pode significar desleixo/negligência ao desempenhar suas próprias funções, resultando em erros de execução próprios ou de terceiros.

\begin{tabular}{|c|c|c|c|c|}
\hline Afago & Alto & Afiliação & $*$ & Alta \\
\hline Afago & $*$ & Afiliação & Baixa & Alta \\
\hline Afago & Média & Afiliação & Média & Alta \\
\hline Afago & Média & Afiliação & Alta & M édia \\
\hline Afago & Baixa & Afiliação & Média & M édia \\
\hline Afago & Baixa & Afiliação & Alta & Baixa \\
\hline
\end{tabular}

A vontade por executar a tarefa da melhor maneira possível pode ser um característica excelente no desempenho humano, desde que não interfira no curso de ação dos demais. Se a Dominância exercida por um colaborador for excessiva, o trabalho de outro poderá ser prejudicado.

\begin{tabular}{|c|c|c|c|c|}
\hline Desempenho & M édio & Dominância & Média & Baixa \\
\hline Desempenho & Alto & Dominância & Baixa & M édia \\
\hline Desempenho & Alto & Dominância & Média & M édia \\
\hline Desempenho & Alto & Dominância & Alta & Alta \\
\hline Desempenho & Baixo & Dominância & Baixa & M édia \\
\hline Desempenho & Baixo & Dominância & Média & Alta \\
\hline Desempenho & Baixo & Dominância & Alta & Alta \\
\hline Desempenho & Médio & Dominância & Baixa & Baixa \\
\hline Desempenho & Médio & Dominância & Alta & Alta \\
\hline
\end{tabular}

A Exibição, gostar de chamar a atenção e exaltar suas ações, é evidentemente um problema para o bom desempenho das tarefas. Analogamente, ser fantasioso ou não-realista para as situações que lhe circundam também pode ser significativo para um erro de Ação, principalmente se ambos os PSFs forem mal desempenhados concomitantemente. 


\begin{tabular}{|c|c|c|c|c|}
\hline Exibição & Alta & Intracepção & $*$ & Alta \\
\hline Exibição & $*$ & Intracepção & Alta & Alta \\
\hline Exibição & Média & Intracepção & Média & M édia \\
\hline Exibição & Média & Intracepção & Baixa & M édia \\
\hline Exibição & Baixa & Intracepção & Média & M édia \\
\hline Exibição & Baixa & Intracepção & Baixa & Baixa \\
\hline
\end{tabular}

A organização o primor por realizar com sucesso uma tarefa ainda que difícil são fatores de suma importância para a Ação, se bem desempenhados simultaneamente, podem amenizar o impacto negativo proveniente de demais PSFs e impedir um deslize em potencial. Por outro lado, caso estejam aquém do esperado, irão influenciar negativamente no bom desempenho de outros PSFs.

\begin{tabular}{|c|c|c|c|c|}
\hline Ordem & Baixa & Persistência & Baixa & Alta \\
\hline Ordem & Baixa & Persistência & Média & Alta \\
\hline Ordem & Baixa & Persistência & Alta & M édia \\
\hline Ordem & Média & Persistência & Baixa & Alta \\
\hline Ordem & Média & Persistência & Média & M édia \\
\hline Ordem & Média & Persistência & Alta & Baixa \\
\hline Ordem & Alta & Persistência & Baixa & M édia \\
\hline Ordem & Alta & Persistência & Média & Baixa \\
\hline Ordem & Alta & Persistência & Alta & Baixa \\
\hline
\end{tabular}

O Grupo PSFs Fatores de Stress Fisiológicos são primordiais na execução de tarefas. Caso uma tarefa demande capacidades físicas do funcionário, tais fatores serão os principais responsáveis por definir a qualidade do trabalho desempenhado.

A Dor ou Desconforto é diretamente afetada pela liberdade que a pessoa tem de realizar os movimentos necessários. Caso uma tarefa exija que o funcionário fique mal posicionado no que diz respeito à ergonomia, evidentemente, a dor se iniciará previamente do que poderia (O.S.H.A., 2000). 


\begin{tabular}{|l|c|c|c|c|}
\hline Constrição de M ovimentos & Baixa & Dor ou Desconforto & Baixa & Baixa \\
\hline Constrição de M ovimentos & Baixa & Dor ou Desconforto & Média & M édia \\
\hline Constrição de M ovimentos & $*$ & Dor ou Desconforto & Alta & Alta \\
\hline Constrição de M ovimentos & Média & Dor ou Desconforto & Baixa & M édia \\
\hline Constrição de M ovimentos & Média & Dor ou Desconforto & Média & M édia \\
\hline Constrição de M ovimentos & Alta & Dor ou Desconforto & $*$ & Alta \\
\hline
\end{tabular}

O PSF Fadiga representa o cansaço que o funcionário irá sentir caso sua aptidão física não suporte o esforço que está exercendo, seja por um esforço moderado mantido por longa duração, ou por um esforço pontual que demande força extrema/acima do que pode prover. Dessa forma, o PSF Exercício Físico é o principal fator de influência direta sobre a Fadiga, por se tratar do representante da capacidade de que o funcionário tem fisicamente. Naturalmente, uma pessoa com melhor preparo físico terá seu ponto de Fadiga atingido após realizar mais esforço do que outra com pior preparo físico.

\begin{tabular}{|c|c|c|c|c|}
\hline Exercício Físico & Baixo & Fadiga & Baixa & Baixa \\
\hline Exercício Físico & Baixo & Fadiga & Média & M édia \\
\hline Exercício Físico & $*$ & Fadiga & Alta & Alta \\
\hline Exercício Físico & Médio & Fadiga & Baixa & Baixa \\
\hline Exercício Físico & Médio & Fadiga & Média & M édia \\
\hline Exercício Físico & Alto & Fadiga & Baixa & Baixa \\
\hline Exercício Físico & Alto & Fadiga & Média & Baixa \\
\hline
\end{tabular}

\begin{tabular}{|c|c|c|c|c|}
\hline Fome ou Sede & Baixa & $\begin{array}{c}\text { Interrupção do Ritmo } \\
\text { Circadiano }\end{array}$ & Baixa & Baixa \\
\hline Fome ou Sede & Baixa & $\begin{array}{c}\text { Interrupção do Ritmo } \\
\text { Circadiano }\end{array}$ & Média & Baixa \\
\hline Fome ou Sede & Baixa & $\begin{array}{c}\text { Interrupção do Ritmo } \\
\text { Circadiano }\end{array}$ & Alta & M édia \\
\hline Fome ou Sede & Média & $\begin{array}{c}\text { Interrupção do Ritmo } \\
\text { Circadiano }\end{array}$ & Baixa & Baixa \\
\hline Fome ou Sede & Média & $\begin{array}{c}\text { Interrupção do Ritmo } \\
\text { Circadiano do Ritmo } \\
\text { Circadiano }\end{array}$ & Média & Baixa \\
\hline Fome ou Sede & Alta & $\begin{array}{c}\text { Interrupção do Ritmo } \\
\text { Circadiano }\end{array}$ & Baixa & M édia \\
\hline Fome ou Sede & Alta & $\begin{array}{c}\text { Interrupção do Ritmo } \\
\text { Circadiano }\end{array}$ & Média & M édia \\
\hline Fome ou Sede & Alta & Interrupção do Ritmo Circ. & Alta & Alta \\
\hline
\end{tabular}




\begin{tabular}{|c|c|c|c|c|}
\hline Longa Duração do Stress & Baixa & Repetição de M ovimentos & Baixa & Baixa \\
\hline Longa Duração do Stress & Baixa & Repetição de M ovimentos & Média & Baixa \\
\hline Longa Duração do Stress & Baixa & Repetição de M ovimentos & Alta & M édia \\
\hline Longa Duração do Stress & Média & Repetição de M ovimentos & Baixa & Baixa \\
\hline Longa Duração do Stress & Média & Repetição de M ovimentos & Média & M édia \\
\hline Longa Duração do Stress & Média & Repetição de M ovimentos & Alta & Alta \\
\hline Longa Duração do Stress & Alta & Repetição de M ovimentos & Baixa & M édia \\
\hline Longa Duração do Stress & Alta & Repetição de M ovimentos & Média & Alta \\
\hline Longa Duração do Stress & Alta & Repetição de M ovimentos & Alta & Alta \\
\hline
\end{tabular}

O SIF abaixo contém três variáveis de entrada, portanto suas regras foram dividas em três.

Todos os três PSFs aqui avaliados pertencem ao Grupo de PSFs Fatores de Stress Psicológicos. O nervosismo pode influenciar fortemente no momento da execução ao diminuir a capacidade do funcionário de concentração.

Caso o PSFs Ameaças (de Falha, de Perda do Emprego, etc.) esteja Baixo:

\begin{tabular}{|c|l|c|c|c|}
\hline $\begin{array}{c}\text { Falta de Recompensas, } \\
\text { Reconhecimento e } \\
\text { Benefícios }\end{array}$ & Baixa & $\begin{array}{c}\text { Motivos Conflitantes sobre } \\
\text { o Desempenho no } \\
\text { Trabalho }\end{array}$ & Baixo & Baixa \\
\hline $\begin{array}{c}\text { Falta de Recompensas, } \\
\text { Reconhecimento e } \\
\text { Benefícios }\end{array}$ & Baixa & $\begin{array}{c}\text { Motivos Conflitantes sobre } \\
\text { o Desempenho no } \\
\text { Trabalho }\end{array}$ & Médio & Baixa \\
\hline $\begin{array}{c}\text { Falta de Recompensas, } \\
\text { Reconhecimento e } \\
\text { Benefícios }\end{array}$ & Baixa & $\begin{array}{c}\text { Motivos Conflitantes sobre } \\
\text { o Desempenho no } \\
\text { Trabalho }\end{array}$ & Alto & Baixa \\
\hline $\begin{array}{c}\text { Falta de Recompensas, } \\
\text { Reconhecimento e } \\
\text { Benefícios }\end{array}$ & Média & $\begin{array}{c}\text { Motivos Conflitantes sobre } \\
\text { o Desempenho no } \\
\text { Trabalho }\end{array}$ & Baixo & Baixa \\
\hline $\begin{array}{c}\text { Falta de Recompensas, } \\
\text { Reconhecimento e } \\
\text { Benefícios }\end{array}$ & Média & $\begin{array}{c}\text { Motivos Conflitantes sobre } \\
\text { o Desempenho no } \\
\text { Trabalho }\end{array}$ & Médio & Baixa \\
\hline $\begin{array}{c}\text { Falta de Recompensas, } \\
\text { Reconhecimento e } \\
\text { Benefícios }\end{array}$ & M édia & $\begin{array}{c}\text { Motivos Conflitantes sobre } \\
\text { o Desempenho no } \\
\text { Trabalho }\end{array}$ & Alto & M édia \\
\hline $\begin{array}{c}\text { Falta de Recompensas, } \\
\text { Reconhecimento e } \\
\text { Benefícios }\end{array}$ & Alta & $\begin{array}{c}\text { Motivos Conflitantes sobre } \\
\text { o Desempenho no } \\
\text { Trabalho }\end{array}$ & Baixo & M édia \\
\hline $\begin{array}{c}\text { Falta de Recompensas, } \\
\text { Reconhecimento e } \\
\text { Benefícios }\end{array}$ & Alta & $\begin{array}{c}\text { Motivos Conflitantes sobre } \\
\text { o Desempenho no } \\
\text { Trabalho }\end{array}$ & M édio & M édia \\
\hline $\begin{array}{c}\text { Falta de Recomp., } \\
\text { Reconhec. e Benefícios }\end{array}$ & Alta & $\begin{array}{c}\text { Motivos Conflitantes sobre } \\
\text { o Desempenho no Trab. }\end{array}$ & Alto & Alta \\
\hline
\end{tabular}


Caso esteja Médio:

\begin{tabular}{|c|l|c|c|c|}
\hline $\begin{array}{c}\text { Falta de Recompensas, } \\
\text { Reconhecimento e } \\
\text { Benefícios }\end{array}$ & Baixa & $\begin{array}{c}\text { Motivos Conflitantes sobre } \\
\text { o Desempenho no } \\
\text { Trabalho }\end{array}$ & Baixo & Baixa \\
\hline $\begin{array}{c}\text { Falta de Recompensas, } \\
\text { Reconhecimento e } \\
\text { Benefícios }\end{array}$ & Baixa & $\begin{array}{c}\text { Motivos Conflitantes sobre } \\
\text { o Desempenho no } \\
\text { Trabalho }\end{array}$ & M édio & M édia \\
\hline $\begin{array}{c}\text { Falta de Recompensas, } \\
\text { Reconhecimento e } \\
\text { Benefícios }\end{array}$ & Baixa & $\begin{array}{c}\text { Motivos Conflitantes sobre } \\
\text { o Desempenho no } \\
\text { Trabalho }\end{array}$ & Alto & M édia \\
\hline $\begin{array}{c}\text { Falta de Recompensas, } \\
\text { Reconhecimento e } \\
\text { Benefícios }\end{array}$ & Média & $\begin{array}{c}\text { Motivos Conflitantes sobre } \\
\text { o Desempenho no } \\
\text { Trabalho }\end{array}$ & Baixo & M édia \\
\hline $\begin{array}{c}\text { Falta de Recompensas, } \\
\text { Reconhecimento e } \\
\text { Benefícios }\end{array}$ & M édia & $\begin{array}{c}\text { Motivos Conflitantes sobre } \\
\text { o Desempenho no } \\
\text { Trabalho }\end{array}$ & Médio & M édia \\
\hline $\begin{array}{c}\text { Falta de Recompensas, } \\
\text { Reconhecimento e } \\
\text { Benefícios }\end{array}$ & Média & $\begin{array}{c}\text { Motivos Conflitantes sobre } \\
\text { o Desempenho no } \\
\text { Trabalho }\end{array}$ & Alto & Alta \\
\hline $\begin{array}{c}\text { Falta de Recompensas, } \\
\text { Reconhecimento e } \\
\text { Benefícios }\end{array}$ & Alta & $\begin{array}{c}\text { Motivos Conflitantes sobre } \\
\text { o Desempenho no } \\
\text { Trabalho }\end{array}$ & Baixo & Alta \\
\hline $\begin{array}{c}\text { Falta de Recompensas, } \\
\text { Reconhecimento e } \\
\text { Benefícios }\end{array}$ & Alta & $\begin{array}{c}\text { Motivos Conflitantes sobre } \\
\text { o Desempenho no } \\
\text { Trabalho }\end{array}$ & M édio & Alta \\
\hline $\begin{array}{c}\text { Falta de Recompensas, } \\
\text { Reconhecimento e } \\
\text { Benefícios }\end{array}$ & Alta & $\begin{array}{c}\text { Motivos Conflitantes sobre } \\
\text { o Desempenho no } \\
\text { Trabalho }\end{array}$ & Alto & Alta \\
\hline
\end{tabular}


E caso esteja Alto:

\begin{tabular}{|c|l|c|c|c|}
\hline $\begin{array}{c}\text { Falta de Recompensas, } \\
\text { Reconhecimento e } \\
\text { Benefícios }\end{array}$ & Baixa & $\begin{array}{c}\text { M otivos Conflitantes sobre } \\
\text { o Desempenho no } \\
\text { Trabalho }\end{array}$ & Baixo & M édia \\
\hline $\begin{array}{c}\text { Falta de Recompensas, } \\
\text { Reconhecimento e } \\
\text { Benefícios }\end{array}$ & Baixa & $\begin{array}{c}\text { M otivos Conflitantes sobre } \\
\text { o Desempenho no } \\
\text { Trabalho }\end{array}$ & Médio & M édia \\
\hline $\begin{array}{c}\text { Falta de Recompensas, } \\
\text { Reconhecimento e } \\
\text { Benefícios }\end{array}$ & Baixa & $\begin{array}{c}\text { Motivos Conflitantes sobre } \\
\text { o Desempenho no } \\
\text { Trabalho }\end{array}$ & Alto & Alta \\
\hline $\begin{array}{c}\text { Falta de Recompensas, } \\
\text { Reconhecimento e } \\
\text { Benefícios }\end{array}$ & Média & $\begin{array}{c}\text { Motivos Conflitantes sobre } \\
\text { o Desempenho no } \\
\text { Trabalho }\end{array}$ & Baixo & M édia \\
\hline $\begin{array}{c}\text { Falta de Recompensas, } \\
\text { Reconhecimento e } \\
\text { Benefícios }\end{array}$ & M édia & $\begin{array}{c}\text { Motivos Conflitantes sobre } \\
\text { o Desempenho no } \\
\text { Trabalho }\end{array}$ & M édio & Alta \\
\hline $\begin{array}{c}\text { Falta de Recompensas, } \\
\text { Reconhecimento e } \\
\text { Benefícios }\end{array}$ & M édia & $\begin{array}{c}\text { Motivos Conflitantes sobre } \\
\text { o Desempenho no } \\
\text { Trabalho }\end{array}$ & Alto \\
\hline $\begin{array}{c}\text { Falta de Recompensas, } \\
\text { Reconhecimento e } \\
\text { Benefícios }\end{array}$ & Alta & $\begin{array}{c}\text { Motivos Conflitantes sobre } \\
\text { o Desempenho no } \\
\text { Trabalho }\end{array}$ & Baixo & M édia \\
\hline $\begin{array}{c}\text { Falta de Recompensas, } \\
\text { Reconhecimento e } \\
\text { Benefícios }\end{array}$ & Alta & $\begin{array}{c}\text { Motivos Conflitantes sobre } \\
\text { o Desempenho no } \\
\text { Trabalho }\end{array}$ & Médio & Alta \\
\hline $\begin{array}{c}\text { Falta de Recompensas, } \\
\text { Reconhecimento e } \\
\text { Benefícios }\end{array}$ & Alta & $\begin{array}{c}\text { Motivos Conflitantes sobre } \\
\text { o Desempenho no } \\
\text { Trabalho }\end{array}$ & Alto & Alta \\
\hline
\end{tabular}

A Carga Pesada de Informações numa primeira análise poderia ser considerada indiferente para a Ação. Por isso, vale ressaltar que a "working memory", isto é, memória utilizada para guardar os aspectos relevantes para a tarefa, bem como as decisões tomadas na etapa anterior, é influenciada diretamente pela quantidade de informação que se deseja armazenar. Como já constatado anteriormente, a "working memory" está presente em qualquer etapa da realização de uma tarefa (Hendrickson, 2010), e contém a constante recapitulação do que se está fazendo e o que ainda falta fazer (Baddeley, 2003). 


\begin{tabular}{|c|c|c|c|c|}
\hline $\begin{array}{c}\text { Carga Pesada de } \\
\text { Informações }\end{array}$ & Baixa & Início Inesperado do Stress & Baixo & Baixa \\
\hline $\begin{array}{c}\text { Carga Pesada de } \\
\text { Informações }\end{array}$ & Baixa & Início Inesperado do Stress & M édio & M édia \\
\hline $\begin{array}{c}\text { Carga Pesada de } \\
\text { Informações }\end{array}$ & Baixa & Início Inesperado do Stress & Alto & Alta \\
\hline $\begin{array}{c}\text { Carga Pesada de } \\
\text { Informações }\end{array}$ & Média & Início Inesperado do Stress & Baixo & Baixa \\
\hline $\begin{array}{c}\text { Carga Pesada de } \\
\text { Informações }\end{array}$ & Média & Início Inesperado do Stress & M édio & M édia \\
\hline $\begin{array}{c}\text { Carga Pesada de } \\
\text { Informações }\end{array}$ & Média & Início Inesperado do Stress & Alto & Alta \\
\hline $\begin{array}{c}\text { Carga Pesada de } \\
\text { Informações }\end{array}$ & Alta & Início Inesperado do Stress & Baixo & M édia \\
\hline $\begin{array}{c}\text { Carga Pesada de } \\
\text { Informações }\end{array}$ & Alta & Início Inesperado do Stress & Médio & Alta \\
\hline $\begin{array}{c}\text { Carga Pesada de } \\
\text { Informações }\end{array}$ & Alta & Início Inesperado do Stress & Alto & Alta \\
\hline
\end{tabular}

Evidentemente, distrações tem um forte impacto na $A c ̧ a \tilde{o}$, uma vez que o objetivo de se analisar possibilidades de erros nesta etapa é identificar potenciais lapsos e deslizes. Uma distração, assim como uma falha em algum dos sentidos (principalmente tato, visão e audição) do funcionário, no momento da execução da tarefa aumenta drasticamente a possibilidade de ocorrer um deslize.

\begin{tabular}{|c|c|c|c|c|}
\hline $\begin{array}{c}\text { Distrações (devido a Ruído, } \\
\text { Clarão, M ovimentos, etc.) }\end{array}$ & Baixa & Perda de Sensibilidade & Baixa & Baixa \\
\hline $\begin{array}{c}\text { Distrações (devido a Ruído, } \\
\text { Clarão, M ovimentos, etc.) }\end{array}$ & Baixa & Perda de Sensibilidade & M édia & M édia \\
\hline $\begin{array}{c}\text { Distrações (devido a Ruído, } \\
\text { Clarão, M ovimentos, etc.) }\end{array}$ & Baixa & Perda de Sensibilidade & Alta & Alta \\
\hline $\begin{array}{c}\text { Distrações (devido a Ruído, } \\
\text { Clarão, M ovimentos, etc.) }\end{array}$ & M édia & Perda de Sensibilidade & Baixa & Baixa \\
\hline $\begin{array}{c}\text { Distrações (devido a Ruído, } \\
\text { Clarão, M ovimentos, etc.) }\end{array}$ & M édia & Perda de Sensibilidade & M édia & M édia \\
\hline $\begin{array}{c}\text { Distrações (devido a Ruído, } \\
\text { Clarão, M ovimentos, etc.) }\end{array}$ & Média & Perda de Sensibilidade & Alta & Alta \\
\hline $\begin{array}{c}\text { Distrações (devido a Ruído, } \\
\text { Clarão, M ovimentos, etc.) }\end{array}$ & Alta & Perda de Sensibilidade & Baixa & Alta \\
\hline $\begin{array}{c}\text { Distrações (devido a Ruído, } \\
\text { Clarão, Movimentos, etc.) }\end{array}$ & Alta & Perda de Sensibilidade & M édia & Alta \\
\hline $\begin{array}{c}\text { Distrações (devido a Ruído, } \\
\text { Clarão, Movimentos, etc.) }\end{array}$ & Alta & Perda de Sensibilidade & Alta & Alta \\
\hline
\end{tabular}




\begin{tabular}{|c|c|c|c|c|}
\hline $\begin{array}{c}\text { Períodos de Vigilância } \\
\text { Longos, sem } \\
\text { Acontecimentos }\end{array}$ & Baixa & $\begin{array}{c}\text { Trabalho M onótono, } \\
\text { Degradante ou Sem } \\
\text { Sentido }\end{array}$ & Baixa & Baixa \\
\hline $\begin{array}{c}\text { Períodos de Vigilância } \\
\text { Longos, sem } \\
\text { Acontecimentos }\end{array}$ & Baixa & $\begin{array}{c}\text { Trabalho M onótono, } \\
\text { Degradante ou Sem } \\
\text { Sentido }\end{array}$ & Média & Baixa \\
\hline $\begin{array}{c}\text { Períodos de Vigilância } \\
\text { Longos, sem } \\
\text { Acontecimentos }\end{array}$ & Baixa & $\begin{array}{c}\text { Trabalho M onótono, } \\
\text { Degradante ou Sem } \\
\text { Sentido }\end{array}$ & Alta & M édia \\
\hline $\begin{array}{c}\text { Períodos de Vigilância } \\
\text { Longos, sem } \\
\text { Acontecimentos }\end{array}$ & Média & $\begin{array}{c}\text { Trabalho M onótono, } \\
\text { Degradante ou Sem } \\
\text { Sentido }\end{array}$ & Baixa & Baixa \\
\hline $\begin{array}{c}\text { Períodos de Vigilância } \\
\text { Longos, sem } \\
\text { Acontecimentos }\end{array}$ & M édia & $\begin{array}{c}\text { Trabalho M onótono, } \\
\text { Degradante ou Sem } \\
\text { Sentido }\end{array}$ & Média & M édia \\
\hline $\begin{array}{c}\text { Períodos de Vigilância } \\
\text { Longos, sem } \\
\text { Acontecimentos }\end{array}$ & Média & $\begin{array}{c}\text { Trabalho M onótono, } \\
\text { Degradante ou Sem } \\
\text { Sentido }\end{array}$ & Alta & Alta \\
\hline $\begin{array}{c}\text { Períodos de Vigilância } \\
\text { Longos, sem } \\
\text { Acontecimentos }\end{array}$ & Alta & $\begin{array}{c}\text { Trabalho M onótono, } \\
\text { Degradante ou Sem } \\
\text { Sentido }\end{array}$ & Baixa & M édia \\
\hline $\begin{array}{c}\text { Períodos de Vigilância } \\
\text { Longos, sem } \\
\text { Acontecimentos }\end{array}$ & Alta & $\begin{array}{c}\text { Trabalho M onótono, } \\
\text { Degradante ou Sem } \\
\text { Sentido }\end{array}$ & Média & Alta \\
\hline $\begin{array}{c}\text { Períodos de Vigilância } \\
\text { Longos, sem } \\
\text { Acontecimentos }\end{array}$ & Alta & $\begin{array}{c}\text { Trabalho M onótono, } \\
\text { Degradante ou Sem } \\
\text { Sentido }\end{array}$ & Alta & Alta \\
\hline
\end{tabular}

Uma influência negativa proveniente de algum colega de trabalho durante a execução da tarefa pode significar um erro de $A c ̧ a \tilde{o}$, pois mudar o que foi planejado sem ter tempo para repensar as consequiências pode ser crítico.

\begin{tabular}{|c|c|c|c|c|}
\hline Reforço Negativo & Baixa & Sugestões Inconsistentes & Baixa & Baixa \\
\hline Reforço Negativo & Baixa & Sugestões Inconsistentes & M édia & M édia \\
\hline Reforço Negativo & Baixa & Sugestões Inconsistentes & Alta & M édia \\
\hline Reforço Negativo & Média & Sugestões Inconsistentes & Baixa & M édia \\
\hline Reforço Negativo & Média & Sugestões Inconsistentes & Média & M édia \\
\hline Reforço Negativo & Média & Sugestões Inconsistentes & Alta & Alta \\
\hline Reforço Negativo & Alta & Sugestões Inconsistentes & Baixa & M édia \\
\hline Reforço Negativo & Alta & Sugestões Inconsistentes & Média & Alta \\
\hline Reforço Negativo & Alta & Sugestões Inconsistentes & Alta & Alta \\
\hline
\end{tabular}




\begin{tabular}{|c|c|c|c|c|}
\hline $\begin{array}{l}\text { Ações desenvolvidas por } \\
\text { Supervisores, Colegas, } \\
\text { Representantes de } \\
\text { Sindicatos, e Pessoal de } \\
\text { Regulamentação }\end{array}$ & $*$ & Comunicação & Baixa & Alta \\
\hline $\begin{array}{l}\text { Ações desenvolvidas por } \\
\text { Supervisores, Colegas, } \\
\text { Representantes de } \\
\text { Sindicatos, e Pessoal de } \\
\text { Regulamentação }\end{array}$ & Baixa & Comunicação & Média & Média \\
\hline $\begin{array}{l}\text { Ações desenvolvidas por } \\
\text { Supervisores, Colegas, } \\
\text { Representantes de } \\
\text { Sindicatos, e Pessoal de } \\
\text { Regulamentação }\end{array}$ & Baixa & Comunicação & Alta & Média \\
\hline $\begin{array}{l}\text { Ações desenvolvidas por } \\
\text { Supervisores, Colegas, } \\
\text { Representantes de } \\
\text { Sindicatos, e Pessoal de } \\
\text { Regulamentação }\end{array}$ & Média & Comunicação & Média & Média \\
\hline $\begin{array}{l}\text { Ações desenvolvidas por } \\
\text { Supervisores, Colegas, } \\
\text { Representantes de } \\
\text { Sindicatos, e Pessoal de } \\
\text { Regulamentação }\end{array}$ & Média & Comunicação & Alta & Baixa \\
\hline $\begin{array}{l}\text { Ações desenvolvidas por } \\
\text { Supervisores, Colegas, } \\
\text { Representantes de } \\
\text { Sindicatos, e Pessoal de } \\
\text { Regulamentação }\end{array}$ & Alta & Comunicação & Média & Baixa \\
\hline $\begin{array}{l}\text { Ações desenvolvidas por } \\
\text { Supervisores, Colegas, } \\
\text { Representantes de } \\
\text { Sindicatos, e Pessoal de } \\
\text { Regulamentação }\end{array}$ & Alta & Comunicação & Alta & Baixa \\
\hline
\end{tabular}


Ambos PSFs aqui avaliados afetam a "working memory" bem como o nervosismo do funcionário. Executar uma tarefa com a consciência de que ela representa uma importante parte do processo no qual está inserida, afeta a maneira como o colaborador se porta durante sua execução, podendo deixá-lo mais susceptível a deslizes e lapsos.

\begin{tabular}{|c|c|c|c|c|}
\hline $\begin{array}{c}\text { Capacidade Crítica da } \\
\text { Tarefa }\end{array}$ & Baixa & $\begin{array}{c}\text { Complexidade da Tarefa } \\
\text { (Carga de Informações) }\end{array}$ & Baixa & Baixa \\
\hline $\begin{array}{c}\text { Capacidade Crítica da } \\
\text { Tarefa }\end{array}$ & Baixa & $\begin{array}{c}\text { Complexidade da Tarefa } \\
\text { (Carga de Informações) }\end{array}$ & Média & M édia \\
\hline $\begin{array}{c}\text { Capacidade Crítica da } \\
\text { Tarefa }\end{array}$ & $*$ & $\begin{array}{c}\text { Complexidade da Tarefa } \\
\text { (Carga de Informações) }\end{array}$ & Alta & Alta \\
\hline $\begin{array}{c}\text { Capacidade Crítica da } \\
\text { Tarefa }\end{array}$ & M édia & $\begin{array}{c}\text { Complexidade da Tarefa } \\
\text { (Carga de Informações) }\end{array}$ & Baixa & Baixa \\
\hline $\begin{array}{c}\text { Capacidade Crítica da } \\
\text { Tarefa }\end{array}$ & M édia & $\begin{array}{c}\text { Complexidade da Tarefa } \\
\text { (Carga de Informações) }\end{array}$ & Média & M édia \\
\hline $\begin{array}{c}\text { Capacidade Crítica da } \\
\text { Tarefa }\end{array}$ & Alta & $\begin{array}{c}\text { Complexidade da Tarefa } \\
\text { (Carga de Informações) }\end{array}$ & $*$ & Alta \\
\hline
\end{tabular}

Os PSFs do SIF abaixo são responsáveis por avaliar quão bem explicado estão os avisos, placas e instruções nos equipamentos. Assim, seu bom desempenho é muito importante para o sucesso desta etapa.

\begin{tabular}{|c|l|c|c|c|}
\hline Cuidados e Advertências & Baixo & $\begin{array}{c}\text { Fatores de Interface de } \\
\text { Hardware }\end{array}$ & Baixo & Alta \\
\hline Cuidados e Advertências & Baixo & $\begin{array}{c}\text { Fatores de Interface de } \\
\text { Hardware }\end{array}$ & Médio & Alta \\
\hline Cuidados e Advertências & Baixo & $\begin{array}{c}\text { Fatores de Interface de } \\
\text { Hardware }\end{array}$ & Alto & M édia \\
\hline Cuidados e Advertências & M édio & $\begin{array}{c}\text { Fatores de Interface de } \\
\text { Hardware }\end{array}$ & Baixo & Alta \\
\hline Cuidados e Advertências & M édio & $\begin{array}{c}\text { Fatores de Interface de } \\
\text { Hardware }\end{array}$ & Médio & M édia \\
\hline Cuidados e Advertências & M édio & $\begin{array}{c}\text { Fatores de Interface de } \\
\text { Hardware }\end{array}$ & Alto & Baixa \\
\hline Cuidados e Advertências & Alto & $\begin{array}{c}\text { Fatores de Interface de } \\
\text { Hardware }\end{array}$ & Baixo & M édia \\
\hline Cuidados e Advertências & Alto & $\begin{array}{c}\text { Fatores de Interface de } \\
\text { Hardware }\end{array}$ & Médio & Baixa \\
\hline Cuidados e Advertências & Alto & $\begin{array}{c}\text { Fatores de Interface de } \\
\text { Hardware }\end{array}$ & Alto & Baixa \\
\hline
\end{tabular}

Para facilitar a exibição, as regras do SIF seguinte foram divididas em três. Da mesma maneira como a ausência de equipamentos necessários, ou qualquer outro tipo de material, irá atrapalhar o planejamento se percebido a priori 
(influenciando em um erro de Decisão na etapa anterior), também irá prejudicar a realização efetiva da tarefa caso seja apenas percebido no momento de sua execução.

Caso o PSF Disponibilidade de Equipamentos Especiais esteja com desempenho Baixo:

\begin{tabular}{|c|c|c|c|c|}
\hline Instrumentos & Baixo & Insumos & Baixo & Alta \\
\hline Instrumentos & Baixo & Insumos & Médio & Alta \\
\hline Instrumentos & Baixo & Insumos & Alto & Alta \\
\hline Instrumentos & Médio & Insumos & Baixo & Alta \\
\hline Instrumentos & Médio & Insumos & Médio & M édia \\
\hline Instrumentos & Médio & Insumos & Alto & M édia \\
\hline Instrumentos & Alto & Insumos & Baixo & Alta \\
\hline Instrumentos & Alto & Insumos & Médio & M édia \\
\hline Instrumentos & Alto & Insumos & Alto & M édia \\
\hline
\end{tabular}

Caso Disponibilidade de Equipamentos Especiais esteja com desempenho Médio:

\begin{tabular}{|c|c|c|c|c|}
\hline Instrumentos & Baixo & Insumos & Baixo & Alta \\
\hline Instrumentos & Baixo & Insumos & Médio & M édia \\
\hline Instrumentos & Baixo & Insumos & Alto & M édia \\
\hline Instrumentos & Médio & Insumos & Baixo & M édia \\
\hline Instrumentos & Médio & Insumos & Médio & M édia \\
\hline Instrumentos & Médio & Insumos & Alto & M édia \\
\hline Instrumentos & Alto & Insumos & Baixo & M édia \\
\hline Instrumentos & Alto & Insumos & Médio & M édia \\
\hline Instrumentos & Alto & Insumos & Alto & Baixa \\
\hline
\end{tabular}

E caso seu desempenho esteja Alto:

\begin{tabular}{|c|c|c|c|c|}
\hline Instrumentos & Baixo & Insumos & Baixo & Alta \\
\hline Instrumentos & Baixo & Insumos & Médio & M édia \\
\hline Instrumentos & Baixo & Insumos & Alto & M édia \\
\hline Instrumentos & Médio & Insumos & Baixo & Média \\
\hline Instrumentos & Médio & Insumos & Médio & Média \\
\hline Instrumentos & Médio & Insumos & Alto & Baixa \\
\hline Instrumentos & Alto & Insumos & Baixo & Média \\
\hline Instrumentos & Alto & Insumos & Médio & Baixa \\
\hline Instrumentos & Alto & Insumos & Alto & Baixa \\
\hline
\end{tabular}

Outra questão que deve ser avaliada por ser capaz de causar impacto direto é a falta de organização na equipe e na empresa como um todo. 


\begin{tabular}{|c|c|c|c|c|}
\hline Estrutura de Equipe & Baixa & Estrutura Organizacional & Baixa & Alta \\
\hline Estrutura de Equipe & Baixa & Estrutura Organizacional & Média & Alta \\
\hline Estrutura de Equipe & Baixa & Estrutura Organizacional & Alta & Alta \\
\hline Estrutura de Equipe & Média & Estrutura Organizacional & Baixa & Alta \\
\hline Estrutura de Equipe & Média & Estrutura Organizacional & Média & M édia \\
\hline Estrutura de Equipe & Média & Estrutura Organizacional & Alta & Baixa \\
\hline Estrutura de Equipe & Alta & Estrutura Organizacional & Baixa & Alta \\
\hline Estrutura de Equipe & Alta & Estrutura Organizacional & Média & Baixa \\
\hline Estrutura de Equipe & Alta & Estrutura Organizacional & Alta & Baixa \\
\hline
\end{tabular}

Por melhor que um funcionário fique na prática da realização de uma tarefa, por já conhecê-la e revisitá-la repetidas vezes, se for privado de descanso e pausas a possibilidade de erro de $A c ̧ a ̃ o$ tenderá a aumentar.

\begin{tabular}{|c|c|c|c|c|}
\hline $\begin{array}{c}\text { Freqüência e } \\
\text { Repetitividade da Tarefa }\end{array}$ & Baixa & $\begin{array}{l}\text { Horas de Trabalho / } \\
\text { Intervalos de Trabalho }\end{array}$ & Baixa & Média \\
\hline $\begin{array}{c}\text { Freqüência e } \\
\text { Repetitividade da Tarefa }\end{array}$ & Baixa & $\begin{array}{l}\text { Horas de Trabalho / } \\
\text { Intervalos de Trabalho }\end{array}$ & Média & Média \\
\hline $\begin{array}{c}\text { Freqüência e } \\
\text { Repetitividade da Tarefa }\end{array}$ & Baixa & $\begin{array}{l}\text { Horas de Trabalho / } \\
\text { Intervalos de Trabalho }\end{array}$ & Alta & Baixa \\
\hline $\begin{array}{c}\text { Freqüência e } \\
\text { Repetitividade da Tarefa }\end{array}$ & Média & $\begin{array}{l}\text { Horas de Trabalho / } \\
\text { Intervalos de Trabalho }\end{array}$ & Baixa & Média \\
\hline $\begin{array}{c}\text { Freqüência e } \\
\text { Repetitividade da Tarefa }\end{array}$ & Média & $\begin{array}{l}\text { Horas de Trabalho / } \\
\text { Intervalos de Trabalho }\end{array}$ & Média & Baixa \\
\hline $\begin{array}{c}\text { Freqüência e } \\
\text { Repetitividade da Tarefa }\end{array}$ & Média & $\begin{array}{c}\text { Horas de Trabalho / } \\
\text { Intervalos de Trabalho }\end{array}$ & Alta & Baixa \\
\hline $\begin{array}{c}\text { Freqüência e } \\
\text { Repetitividade da Tarefa }\end{array}$ & Alta & $\begin{array}{l}\text { Horas de Trabalho / } \\
\text { Intervalos de Trabalho }\end{array}$ & Baixa & Alta \\
\hline $\begin{array}{c}\text { Freqüência e } \\
\text { Repetitividade da Tarefa }\end{array}$ & Alta & $\begin{array}{l}\text { Horas de Trabalho / } \\
\text { Intervalos de Trabalho }\end{array}$ & Média & Alta \\
\hline $\begin{array}{c}\text { Freqüência e } \\
\text { Repetitividade da Tarefa }\end{array}$ & Alta & $\begin{array}{l}\text { Horas de Trabalho / } \\
\text { Intervalos de Trabalho }\end{array}$ & Alta & Média \\
\hline
\end{tabular}

Conhecer os resultados não afeta erros de execução, apenas indiretamente: causa impacto no momento de decidir como agir, o que caracteriza a etapa de Decisão e não a de Ação, por não poder ser considerado um lapso. Por outro lado, a precariedade da disponibilidade de explicação clara a respeito dos procedimentos pode causar um erro de $A c ̧ a \tilde{o}$ : se o funcionário se deparar com alguma dúvida e não tiver oportunidade de saná-la; ou ainda se algum procedimento mal escrito for a causa da manifestação de uma incerteza de como 
agir, seja por se diferenciar da Informação recebida anteriormente ou por divergências em relação ao planejamento do seu curso de ação.

\begin{tabular}{|c|c|c|c|c|}
\hline $\begin{array}{c}\text { Feedback (Conhecimento } \\
\text { de Resultados) }\end{array}$ & $*$ & $\begin{array}{c}\text { Procedimentos (Escritos ou } \\
\text { Não Escritos) }\end{array}$ & Baixo & Alto \\
\hline $\begin{array}{c}\text { Feedback (Conhecimento } \\
\text { de Resultados) }\end{array}$ & $*$ & $\begin{array}{c}\text { Procedimentos (Escritos ou } \\
\text { Não Escritos) }\end{array}$ & Médio & M édio \\
\hline $\begin{array}{c}\text { Feedback (Conhecimento } \\
\text { de Resultados) }\end{array}$ & $*$ & $\begin{array}{c}\text { Procedimentos (Escritos ou } \\
\text { Não Escritos) }\end{array}$ & Alto & Baixo \\
\hline
\end{tabular}

Similar ao que acontece com os PSFs Freqüência e Repetitividade da Tarefa; e Horas de Trabalho / Intervalos de Trabalho, os PSFs abaixo tratam de como a pausa é importante para que o funcionário seja capaz de manter a boa qualidade na execução de suas tarefas. Não obstante, estes dois SIFs terão suas saídas agrupadas e serão avaliados conjuntamente em um SIF de segundo nível.

O Rodízio de Turnos só será bem aproveitado se existir um número de funcionários grande o suficiente para que um funcionário cansado só volte a realizar a tarefa quando já estiver recuperado suas energias. Analogamente, a Quantidade de Pessoal não será útil, mesmo quando Alta, caso não se esteja sendo aplicados Rodízio de Turnos eficientemente, isto é: não é eficaz ter um grande número de funcionários disponíveis, se o Rodízio de Turnos estiver mal dimensionado, fazendo com que no momento de descanso os funcionários fiquem mais tempo do que precisam, para a seguir passar um tempo excessivo sem pausa.

\begin{tabular}{|c|c|c|c|c|}
\hline Quantidade de Pessoal & Baixa & Rodízio de Turnos & Baixo & Alta \\
\hline Quantidade de Pessoal & Baixa & Rodízio de Turnos & Médio & Alta \\
\hline Quantidade de Pessoal & Baixa & Rodízio de Turnos & Alto & M édia \\
\hline Quantidade de Pessoal & M édia & Rodízio de Turnos & Baixo & Alta \\
\hline Quantidade de Pessoal & Média & Rodízio de Turnos & Médio & M édia \\
\hline Quantidade de Pessoal & Média & Rodízio de Turnos & Alto & Baixa \\
\hline Quantidade de Pessoal & Alta & Rodízio de Turnos & Baixo & M édia \\
\hline Quantidade de Pessoal & Alta & Rodízio de Turnos & Médio & Baixa \\
\hline Quantidade de Pessoal & Alta & Rodízio de Turnos & Alto & Baixa \\
\hline
\end{tabular}

Condição Física afeta diretamente Ação por ser capaz de invalidar, ou ao menos depreciar, a capacidade de executar tarefas. Como já dito anteriormente, problemas de saúde afetam todas as etapas relativas a realização de uma tarefa: Informação, Decisão e Ação. A influência de agentes externos pode atrapalhar a 
execução ao constituir um fator de nervosismo, abalando a capacidade de concentração do colaborador.

\begin{tabular}{|c|c|c|c|c|}
\hline Condição Física/Saúde & Baixa & $\begin{array}{c}\text { Influência de outros } \\
\text { agentes externos (pessoas, } \\
\text { família) }\end{array}$ & $*$ & Alta \\
\hline Condição Física/Saúde & $*$ & $\begin{array}{c}\text { Influência de outros } \\
\text { agentes externos (pessoas, } \\
\text { família) }\end{array}$ & Baixa & Alta \\
\hline Condição Física/Saúde & M édia & $\begin{array}{c}\text { Influência de outros } \\
\text { agentes externos (pessoas, } \\
\text { família) }\end{array}$ & Média & Média \\
\hline Condição Física/Saúde & Média & $\begin{array}{c}\text { Influência de outros } \\
\text { agentes externos (pessoas, } \\
\text { família) }\end{array}$ & Alta & Baixa \\
\hline Condição Física/Saúde & Alta & $\begin{array}{c}\text { Influência de outros } \\
\text { agentes externos (pessoas, } \\
\text { família) }\end{array}$ & Média & Baixa \\
\hline Condição Física/Saúde & Alta & $\begin{array}{c}\text { Influência de outros } \\
\text { agentes externos (pessoas, } \\
\text { família) }\end{array}$ & Alta & Baixa \\
\hline
\end{tabular}

A Experiência afeta a $A c ̧ a \tilde{o}$ ao influenciar o quanto de perícia o funcionário tem em relação a determinada tarefa. O Conhecimento de Padrões de Desempenho permite ao colaborador perceber, durante a execução da tarefa, se a mesma está sendo feita corretamente, ou se deve tomar alguma atitude para mudar seu andamento.

\begin{tabular}{|c|c|c|c|c|}
\hline $\begin{array}{c}\text { Conhecimento de Padrões } \\
\text { de Desempenho }\end{array}$ & Baixo & Experiência & Baixa & Alta \\
\hline $\begin{array}{c}\text { Conhecimento de Padrões } \\
\text { de Desempenho }\end{array}$ & Baixo & Experiência & M édia & Alta \\
\hline $\begin{array}{c}\text { Conhecimento de Padrões } \\
\text { de Desempenho }\end{array}$ & Baixo & Experiência & Alta & M édia \\
\hline $\begin{array}{c}\text { Conhecimento de Padrões } \\
\text { de Desempenho }\end{array}$ & Médio & Experiência & Baixa & Alta \\
\hline $\begin{array}{c}\text { Conhecimento de Padrões } \\
\text { de Desempenho }\end{array}$ & Médio & M édia & M édia \\
\hline $\begin{array}{c}\text { Conhecimento de Padrões } \\
\text { de Desempenho }\end{array}$ & Médio & Experiência & Alta & Baixa \\
\hline $\begin{array}{c}\text { Conhecimento de Padrões } \\
\text { de Desempenho }\end{array}$ & Alto & Experiência & Média & Baixa \\
\hline $\begin{array}{c}\text { Conhecimento de Padrões } \\
\text { de Desempenho }\end{array}$ & Alto & Experiência & Alta & Baixa \\
\hline $\begin{array}{c}\text { Conhecimento de Padrões } \\
\text { de Desempenho }\end{array}$ & Alto & Édia \\
\hline
\end{tabular}


Tensão Física, similar ao que ocorre com o PSF Condição Física/Saúde, tem influência direta na etapa Ação. Como já citado anteriormente, Tensão Mental afeta todas as etapas, particularmente no caso da Ação pode aumentar a ocorrência de lapsos e deslizes ao diminuir a concentração do funcionário.

\begin{tabular}{|c|c|c|c|c|}
\hline Motivação & Baixa & Tensão Mental ou Física & Baixa & M édia \\
\hline Motivação & Baixa & Tensão Mental ou Física & Média & Alta \\
\hline Motivação & Baixa & Tensão Mental ou Física & Alta & Alta \\
\hline Motivação & M édia & Tensão Mental ou Física & Baixa & Baixa \\
\hline Motivação & M édia & Tensão Mental ou Física & Média & M édia \\
\hline Motivação & Média & Tensão Mental ou Física & Alta & Alta \\
\hline Motivação & Alta & Tensão Mental ou Física & Baixa & Baixa \\
\hline Motivação & Alta & Tensão Mental ou Física & Média & Baixa \\
\hline Motivação & Alta & Tensão Mental ou Física & Alta & M édia \\
\hline
\end{tabular}

Os PSFs do SIF abaixo tem grande importância pois são representativos da capacidade do funcionário de identificar quais métodos e políticas devem ser observados com mais apreço, e em quais momentos deve fazê-lo. Lhe permite executar a tarefa obedecendo corretamente os procedimentos que mais se adéquam ao trabalho que está desempenhando.

\begin{tabular}{|c|c|c|c|c|}
\hline $\begin{array}{l}\text { Nível de cultura de } \\
\text { segurança }\end{array}$ & Baixo & $\begin{array}{l}\text { Nível de cultura } \\
\text { organizacional }\end{array}$ & Baixo & Alta \\
\hline $\begin{array}{l}\text { Nível de cultura de } \\
\text { segurança }\end{array}$ & Baixo & $\begin{array}{l}\text { Nível de cultura } \\
\text { organizacional }\end{array}$ & Médio & Alta \\
\hline $\begin{array}{l}\text { Nível de cultura de } \\
\text { segurança }\end{array}$ & Baixo & $\begin{array}{l}\text { Nível de cultura } \\
\text { organizacional }\end{array}$ & Alto & Média \\
\hline $\begin{array}{l}\text { Nível de cultura de } \\
\text { segurança }\end{array}$ & Médio & $\begin{array}{l}\text { Nível de cultura } \\
\text { organizacional }\end{array}$ & Baixo & Alta \\
\hline $\begin{array}{l}\text { Nível de cultura de } \\
\text { segurança }\end{array}$ & M édio & $\begin{array}{l}\text { Nível de cultura } \\
\text { organizacional }\end{array}$ & Médio & Média \\
\hline $\begin{array}{l}\text { Nível de cultura de } \\
\text { segurança }\end{array}$ & Médio & $\begin{array}{l}\text { Nível de cultura } \\
\text { organizacional }\end{array}$ & Alto & Baixa \\
\hline $\begin{array}{l}\text { Nível de cultura de } \\
\text { segurança }\end{array}$ & Alto & $\begin{array}{l}\text { Nível de cultura } \\
\text { organizacional }\end{array}$ & Baixo & M édia \\
\hline $\begin{array}{l}\text { Nível de cultura de } \\
\text { segurança }\end{array}$ & Alto & $\begin{array}{l}\text { Nível de cultura } \\
\text { organizacional }\end{array}$ & Médio & Baixa \\
\hline $\begin{array}{l}\text { Nível de cultura de } \\
\text { segurança }\end{array}$ & Alto & $\begin{array}{l}\text { Nível de cultura } \\
\text { organizacional }\end{array}$ & Alto & Baixa \\
\hline
\end{tabular}


Os fatores internos Nível de Práticas e Qualidade do Treinamento são críticos nesta etapa, pois moldam a maneira como o funcionário de fato executará as suas funções.

\begin{tabular}{|c|c|c|c|c|}
\hline Nível de práticas & Baixo & Qualidade do Treinamento & Baixa & Alta \\
\hline Nível de práticas & Baixo & Qualidade do Treinamento & M édia & Alta \\
\hline Nível de práticas & Baixo & Qualidade do Treinamento & Alta & M édia \\
\hline Nível de práticas & M édio & Qualidade do Treinamento & Baixa & Alta \\
\hline Nível de práticas & M édio & Qualidade do Treinamento & Média & M édia \\
\hline Nível de práticas & M édio & Qualidade do Treinamento & Alta & Baixa \\
\hline Nível de práticas & Alto & Qualidade do Treinamento & Baixa & M édia \\
\hline Nível de práticas & Alto & Qualidade do Treinamento & Média & Baixa \\
\hline Nível de práticas & Alto & Qualidade do Treinamento & Alta & Baixa \\
\hline
\end{tabular}

\subsubsection{2.}

\section{SIFs Hierárquicos do Segundo Nível}

Vale lembrar que as regras a seguir se diferem das anteriores pois todas suas variáveis são medidas em possibilidades de erro, inclusive as de entrada, anteriormente medidas em qualidade de desempenho.

\begin{tabular}{|c|c|c|c|c|}
\hline $\begin{array}{c}\text { Se possibilidade de erro } \\
\text { de Informação do Sub- } \\
\text { grupo }\end{array}$ & é & $\begin{array}{c}\text { e possibilidade de erro de } \\
\text { Informação do Sub-grupo }\end{array}$ & é & $\begin{array}{c}\text { Então } \\
\text { possibilidade } \\
\text { de erro de } \\
\text { Ação é }\end{array}$ \\
\hline $\begin{array}{c}\text { Capacidade Analítica } \\
\text { Capacidade de } \\
\text { Classificação }\end{array}$ & Baixa & $\begin{array}{c}\text { Capacidade de } \\
\text { Antecipação } \\
\text { Capacidade de Tomada de } \\
\text { Decisões }\end{array}$ & Baixa & Baixa \\
\hline II & Baixa & II & Média & Baixa \\
\hline II & Baixa & II & Alta & M édia \\
\hline II & Média & II & Baixa & Baixa \\
\hline II & Média & II & Média & M édia \\
\hline II & Média & II & Alta & Alta \\
\hline II & Alta & II & Baixa & M édia \\
\hline II & Alta & II & Média & Alta \\
\hline II & Alta & II & Alta & Alta \\
\hline
\end{tabular}




\begin{tabular}{|c|c|c|c|c|}
\hline $\begin{array}{c}\text { Inteligência numérica } \\
\text { (capacidade de cálculos) } \\
\text { Percepção de séries }\end{array}$ & Baixa & $\begin{array}{c}\text { Memória } \\
\text { Predisposição para novos } \\
\text { conhecimentos }\end{array}$ & Baixa & Baixa \\
\hline II & Baixa & II & Média & M édia \\
\hline II & Baixa & $\|$ & Alta & Alta \\
\hline II & Média & II & Baixa & Baixa \\
\hline II & Média & II & Média & M édia \\
\hline II & Média & $\|$ & Alta & Alta \\
\hline II & Alta & II & Baixa & M édia \\
\hline$I I$ & Alta & II & Média & Alta \\
\hline II & Alta & II & Alta & Alta \\
\hline
\end{tabular}

Os PSFs Agressão e Autonomia são fatores de personalidade indiferentes para a Ação, portanto este SIF de segundo nível só depende da possibilidade de erro parcial proveniente do SIF de primeiro nível que composto pelos PSFs Afago e Afiliação.

\begin{tabular}{|c|c|c|c|c|}
\hline $\begin{array}{c}\text { Afago } \\
\text { Afiliação }\end{array}$ & Baixa & $\begin{array}{c}\text { Agressão } \\
\text { Autonomia }\end{array}$ & Ind. & Baixa \\
\hline II & Média & II & Ind. & M édia \\
\hline II & Alta & II & Ind. & Alta \\
\hline
\end{tabular}

O SIF abaixo reflete o quanto a personalidade do funcionário é capaz de incentivar o seu desempenho durante a realização de uma tarefa, bem como sua vontade por terminá-la com sucesso.

\begin{tabular}{|c|c|c|c|c|}
\hline $\begin{array}{c}\text { Desempenho } \\
\text { Dominância }\end{array}$ & Baixa & $\begin{array}{c}\text { Ordem } \\
\text { Persistência }\end{array}$ & Baixa & Baixa \\
\hline II & Baixa & II & Média & M édia \\
\hline II & Baixa & II & Alta & M édia \\
\hline II & Média & II & Baixa & M édia \\
\hline II & Média & II & Média & M édia \\
\hline II & Média & $\|$ & Alta & Alta \\
\hline II & Alta & $\|$ & Baixa & M édia \\
\hline II & Alta & II & Média & Alta \\
\hline II & Alta & II & Alta & Alta \\
\hline
\end{tabular}

O SIF abaixo depende apenas da possibilidade de erro parcial do SIF de primeiro nível formado por Exibição e Intracepção, uma vez que Assistência e Deferência são indiferentes para esta etapa. 


\begin{tabular}{|c|c|c|c|c|}
\hline $\begin{array}{c}\text { Assistência } \\
\text { Deferência }\end{array}$ & Ind. & $\begin{array}{c}\text { Exibição } \\
\text { Intracepção }\end{array}$ & Baixa & Baixa \\
\hline II & Ind. & II & Média & M édia \\
\hline II & Ind. & II & Alta & Alta \\
\hline
\end{tabular}

Se apesar de grande Repetição de Movimentos a Dor ou Desconforto for muito Baixa, não é esperado que ocorra erro de Ação. Porém, pode ser considerado como um equilíbrio instável, já que qualquer dor proveniente da repetição que venha a ocorrer será intensificada rapidamente.

\begin{tabular}{|c|c|c|c|c|}
\hline $\begin{array}{c}\text { Constrição de M ovimentos } \\
\text { Dor ou Desconforto }\end{array}$ & Baixa & $\begin{array}{c}\text { Longa Duração do Stress } \\
\text { Repetição de M ovimentos }\end{array}$ & Baixa & Baixa \\
\hline II & Baixa & II & Média & M édia \\
\hline II & Baixa & II & Alta & M édia \\
\hline II & Média & II & Baixa & M édia \\
\hline II & Média & II & Média & M édia \\
\hline II & Média & II & Alta & Alta \\
\hline II & Alta & II & Baixa & Alta \\
\hline II & Alta & II & Média & Alta \\
\hline II & Alta & II & Alta & Alta \\
\hline
\end{tabular}

\begin{tabular}{|c|c|c|c|c|}
\hline $\begin{array}{c}\text { Exercício Físico } \\
\text { Fadiga }\end{array}$ & Baixa & $\begin{array}{c}\text { Fome ou Sede } \\
\text { Interrupção do Ritmo } \\
\text { Circadiano }\end{array}$ & Baixa & Baixa \\
\hline II & Baixa & $\|$ & Média & Baixa \\
\hline$I I$ & Baixa & $\|$ & Alta & M édia \\
\hline$I I$ & Média & $\|$ & Baixa & Baixa \\
\hline$I I$ & Média & $\|$ & Média & M édia \\
\hline$I I$ & Média & $\|$ & Alta & Alta \\
\hline$I I$ & Alta & $\|$ & Baixa & M édia \\
\hline$I I$ & Alta & II & Média & Alta \\
\hline$I I$ & Alta & II & Alta & Alta \\
\hline
\end{tabular}

Como já explicado anteriormente uma variável de entrada deste SIF trata do nervosismo constante ou intermitente sobre o funcionário, enquanto a outra trata de obstáculos para o bom funcionamento da "working memory", ambos de vital importância para a Ação. 


\begin{tabular}{|c|c|c|c|c|}
\hline $\begin{array}{l}\text { Ameaças (de Falha, de } \\
\text { Perda do Emprego, etc.) } \\
\text { Falta de Recompensas, } \\
\text { Reconhecimento e } \\
\text { Benefícios } \\
\text { Motivos Conflitantes sobre } \\
\text { o Desempenho no Trabalho }\end{array}$ & Baixa & $\begin{array}{l}\text { Carga Pesada de } \\
\text { Informações } \\
\text { Início Inesperado do Stress }\end{array}$ & Baixa & Baixa \\
\hline II & Baixa & II & Média & Baixa \\
\hline II & Baixa & II & Alta & Média \\
\hline II & Média & II & Baixa & Baixa \\
\hline II & Média & II & Média & Média \\
\hline II & Média & II & Alta & Alta \\
\hline II & Alta & II & Baixa & Média \\
\hline II & Alta & II & Média & Alta \\
\hline II & Alta & II & Alta & Alta \\
\hline
\end{tabular}

\begin{tabular}{|c|c|c|c|c|}
\hline Reforço Negativo & Baixa & $\begin{array}{c}\text { Períodos de Vigilância } \\
\text { Longos, sem } \\
\text { Acontecimentos } \\
\text { Trabalho Monótono, } \\
\text { Degradante ou Sem } \\
\text { Sentido }\end{array}$ & Baixa & Baixa \\
\hline II & Baixa & II & Média & Baixa \\
\hline II & Baixa & II & Alta & Média \\
\hline II & Média & II & Baixa & Média \\
\hline II & Média & II & Média & Média \\
\hline II & Média & II & Alta & Alta \\
\hline II & Alta & II & Baixa & Alta \\
\hline II & Alta & II & Média & Alta \\
\hline II & Alta & II & Alta & Alta \\
\hline
\end{tabular}

Este SIF trata dos PSFs pertinentes a tarefas baseadas em comunicação e/ou trabalho em equipe. Duas regras incoerentes do ponto de vista prático ocorrem neste SIF, são os casos em que uma variável está indicando Alta possibilidade de erro parcial, enquanto outra está indicando Baixa, e vice-versa. Não são factíveis, pois é pouco provável que a estrutura de equipe esteja ruim enquanto as ações desenvolvidas pelos colegas e a comunicação estiverem boas. Porém, matematicamente, o caso será avaliado (bem como o caso oposto) com peso de importância igual para os dois, ou seja, a saída deste SIF de segundo nível será Média. 


\begin{tabular}{|c|c|c|c|c|}
\hline $\begin{array}{l}\text { Ações desenvolvidas por } \\
\text { Supervisores, Colegas, } \\
\text { Representantes de } \\
\text { Sindicatos, e Pessoal de } \\
\text { Regulamentação } \\
\text { Comunicação }\end{array}$ & Baixa & $\begin{array}{l}\text { Estrutura de Equipe } \\
\text { Estrutura Organizacional }\end{array}$ & Baixa & Baixa \\
\hline II & Baixa & II & Média & Baixa \\
\hline II & Baixa & II & Alta & Média \\
\hline II & Média & II & Baixa & Baixa \\
\hline II & Média & II & Média & Média \\
\hline II & Média & II & Alta & Alta \\
\hline II & Alta & II & Baixa & M édia \\
\hline II & Alta & II & Média & Alta \\
\hline II & Alta & II & Alta & Alta \\
\hline
\end{tabular}

O SIF de segundo nível abaixo, que trata dos PSFs Cuidados e Advertências, Fatores de Interface de Hardware, Feedback (Conhecimento de Resultados), e Procedimentos (Escritos ou Não Escritos) também contém os PSFs Métodos de Trabalho e Políticas da Planta. Porém, estes dois últimos são indiferentes para a etapa de Ação.

\begin{tabular}{|c|c|c|c|c|}
\hline $\begin{array}{c}\text { Cuidados e Advertências } \\
\begin{array}{c}\text { Fatores de Interface de } \\
\text { Hardware }\end{array}\end{array}$ & Baixa & $\begin{array}{c}\text { Feedback (Conhecimento } \\
\text { de Resultados) } \\
\text { Procedimentos (Escritos ou } \\
\text { Não Escritos) }\end{array}$ & Baixa & Baixa \\
\hline II & Baixa & II & Média & Baixa \\
\hline II & Baixa & II & Alta & M édia \\
\hline II & Média & II & Baixa & M édia \\
\hline II & Média & II & Média & M édia \\
\hline II & Média & II & Alta & Alta \\
\hline II & Alta & II & Baixa & M édia \\
\hline II & Alta & II & Média & Alta \\
\hline II & Alta & II & Alta & Alta \\
\hline
\end{tabular}

Conforme comentado no SIF de primeiro nível que trata destes PSFs, os mesmos são altamente correlacionáveis, por isso são avaliados em conjunto no segundo nível. A Baixa Quantidade de Pessoal, e precário Rodízio de Turnos só podem se manifestar negativamente caso a Freqüência e a Repetitividade da Tarefa estejam significativas, bem como as Horas e Intervalos estejam ruins. Caso tal sub-grupo de PSFs compense o mal desempenho do outro, pode-se considerar que ocorre um equilíbrio instável, pois uma modificação suave neste quadro 
poderá impactar fortemente o resultado da possibilidade de erro parcial deste SIF para a etapa de $A c ̧ \tilde{a} o$.

\begin{tabular}{|c|c|c|c|c|}
\hline $\begin{array}{c}\text { Freqüência e } \\
\text { Repetitividade da Tarefa } \\
\text { Horas de Trabalho / } \\
\text { Intervalos de Trabalho }\end{array}$ & Baixa & $\begin{array}{c}\text { Quantidade de Pessoal } \\
\text { Rodízio de Turnos }\end{array}$ & Baixa & Baixa \\
\hline II & Baixa & II & Média & Baixa \\
\hline II & Baixa & II & Alta & Baixa \\
\hline II & Média & II & Baixa & Média \\
\hline II & Média & II & Média & Média \\
\hline II & Média & II & Alta & Alta \\
\hline II & Alta & II & Baixa & Média \\
\hline II & Alta & II & Média & Alta \\
\hline II & Alta & II & Alta & Alta \\
\hline
\end{tabular}

Caso a Motivação bem como a Tensão Mental ou Física estiverem indicando Alta possibilidade de erro de Ação significa que: a falta de vontade e de capacidade de executar a tarefa impedirão qualquer Decisão bem tomada no passo anterior de ser posta em prática.

\begin{tabular}{|c|c|c|c|c|}
\hline $\begin{array}{c}\text { Condição Física/Saúde } \\
\text { Influência de outros } \\
\text { agentes externos (pessoas, } \\
\text { família) }\end{array}$ & Baixa & Tensão Mental ou Física & Baixa & Baixa \\
\hline II & Baixa & II & Média & M édia \\
\hline II & Baixa & II & Alta & Alta \\
\hline II & Média & II & Baixa & M édia \\
\hline II & Média & II & Média & M édia \\
\hline II & Média & II & Alta & Alta \\
\hline$I I$ & Alta & II & Baixa & M édia \\
\hline II & Alta & II & Média & Alta \\
\hline II & Alta & II & Alta & Alta \\
\hline
\end{tabular}

Novamente, para melhor exibir as regras deste SIF, três grupos de regras serão apresentados.

Uma situação interessante tratada por este SIF é a de o funcionário ter treinamento e práticas ruins, enquanto tem bons conhecimentos de padrões de desempenho e experiência, assim como bons níveis de cultura de segurança e organizacional. Independentemente do bom conhecimento adquirido a respeito de sua empresa, lhe falta perícia e habilidade para executar a tarefa com sucesso (resultando em Alta possibilidade de erro de Ação para este SIF). Isto significa 
que, caso os PSFs Nível de Práticas e Qualidade do Treinamento estejam indicando Alta possibilidade de erro de Ação em seu SIF de primeiro nível, este SIF de segundo nível também resultará em Alta possibilidade de erro de Ação, independentemente do desempenho de suas demais variáveis de entrada.

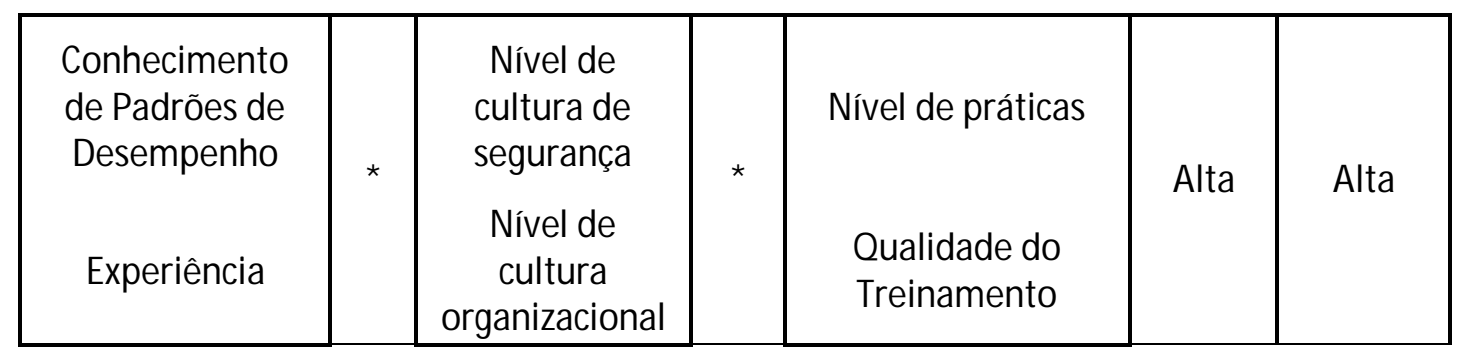

Caso o SIF do primeiro nível que engloba Nível de Práticas e Qualidade do Treinamento esteja indicando Baixa possibilidade de erro de Ação:

\begin{tabular}{|c|c|c|c|c|}
\hline $\begin{array}{c}\text { Conhecimento de Padrões } \\
\text { de Desempenho } \\
\text { Experiência }\end{array}$ & Baixa & $\begin{array}{c}\text { Nível de cultura de } \\
\text { segurança } \\
\text { Nível de cultura } \\
\text { organizacional }\end{array}$ & Baixa & Baixa \\
\hline II & Baixa & II & Média & Baixa \\
\hline II & Baixa & II & Alta & Baixa \\
\hline II & Média & II & Baixa & Baixa \\
\hline II & Média & II & Média & M édia \\
\hline II & Média & II & Alta & Média \\
\hline II & Alta & II & Baixa & Baixa \\
\hline II & Alta & II & Média & M édia \\
\hline II & Alta & II & Alta & Alta \\
\hline
\end{tabular}

E caso esteja indicando Média:

\begin{tabular}{|c|c|c|c|c|}
\hline $\begin{array}{c}\text { Conhecimento de Padrões } \\
\text { de Desempenho } \\
\text { Experiência }\end{array}$ & Baixa & $\begin{array}{c}\text { Nível de cultura de } \\
\text { segurança } \\
\text { Nível de cultura } \\
\text { organizacional }\end{array}$ & Baixa & M édia \\
\hline II & Baixa & II & Média & M édia \\
\hline II & Baixa & II & Alta & M édia \\
\hline II & Média & II & Baixa & M édia \\
\hline II & Média & II & Média & M édia \\
\hline II & Média & II & Alta & Alta \\
\hline II & Alta & II & Baixa & M édia \\
\hline II & Alta & II & Média & Alta \\
\hline II & Alta & II & Alta & Alta \\
\hline
\end{tabular}




\subsubsection{3.}

\section{SIFs Hierárquicos do Terceiro Nível}

Como já explicado nos respectivos SIFs do segundo nível, um sub-grupo trata do nervosismo e da "working memory" enquanto outro é responsável por representar as nuances relativas à equipe a qual o funcionário pertence.

\begin{tabular}{|c|c|c|c|c|}
\hline $\begin{array}{c}\text { Se possibilidade de erro } \\
\text { de Informação do Sub- } \\
\text { grupo }\end{array}$ & é & $\begin{array}{l}\text { e possibilidade de erro de } \\
\text { Informação do Sub-grupo }\end{array}$ & é & $\begin{array}{c}\text { Então } \\
\text { possibilidade } \\
\text { de erro de } \\
\text { Ação é }\end{array}$ \\
\hline $\begin{array}{l}\text { Ameaças (de Falha, de } \\
\text { Perda do Emprego, etc.) } \\
\text { Falta de Recompensas, } \\
\text { Reconhecimento e } \\
\text { Benefícios } \\
\text { Motivos Conflitantes } \\
\text { sobre o Desempenho no } \\
\text { Trabalho } \\
\text { Carga Pesada de } \\
\text { Informações } \\
\text { Início Inesperado do } \\
\text { Stress }\end{array}$ & Baixa & $\begin{array}{l}\text { Ações desenvolvidas por } \\
\text { Supervisores, Colegas, } \\
\text { Representantes de } \\
\text { Sindicatos, e Pessoal de } \\
\text { Regulamentação } \\
\text { Comunicação } \\
\text { Estrutura de Equipe } \\
\text { Estrutura Organizacional }\end{array}$ & Baixa & Baixa \\
\hline II & Baixa & II & Média & Média \\
\hline II & Baixa & II & Alta & Média \\
\hline II & Média & II & Baixa & Média \\
\hline II & Média & II & Média & Média \\
\hline II & Média & II & Alta & Alta \\
\hline II & Alta & II & Baixa & Média \\
\hline II & Alta & II & Média & Alta \\
\hline II & Alta & II & Alta & Alta \\
\hline
\end{tabular}

O SIF abaixo engloba o PSF Alta Velocidade na Execução da Tarefa, e é pertinente apenas para tarefas que demandem bom desempenho físico por parte do colaborador. 


\begin{tabular}{|c|c|c|c|c|}
\hline $\begin{array}{c}\text { Constrição de M ovimentos } \\
\text { Dor ou Desconforto } \\
\text { Longa Duração do Stress } \\
\text { Repetição de M ovimentos }\end{array}$ & Baixa & $\begin{array}{c}\text { Alta Velocidade na } \\
\text { Execução da Tarefa }\end{array}$ & Baixa & Baixa \\
\hline II & Baixa & II & Média & Baixa \\
\hline II & Baixa & II & Alta & Média \\
\hline II & Média & II & Baixa & Média \\
\hline II & Média & II & Média & Média \\
\hline II & Média & II & Alta & Alta \\
\hline II & Alta & II & $*$ & Alta \\
\hline
\end{tabular}

Os PSFs contidos neste SIF são de grande importância para tarefas intrinsecamente intelectuais, tendo menor impacto em tarefas operacionais.

\begin{tabular}{|c|c|c|c|c|}
\hline $\begin{array}{c}\text { Capacidade Analítica } \\
\text { Capacidade de Classificação } \\
\text { Capacidade de Antecipação } \\
\text { Capacidade de Tomada de } \\
\text { Decisões }\end{array}$ & Baixa & $\begin{array}{c}\text { Inteligência numérica } \\
\text { (capacidade de cálculos) } \\
\text { Percepção de séries } \\
\text { Memória } \\
\text { Predisposição para novos } \\
\text { conhecimentos }\end{array}$ & Baixa & Baixa \\
\hline II & Baixa & II & Média & Média \\
\hline II & Baixa & II & Alta & Média \\
\hline II & Média & II & Baixa & Média \\
\hline II & Média & II & Média & Média \\
\hline II & Média & II & Alta & Alta \\
\hline II & Alta & II & Baixa & Média \\
\hline II & Alta & II & Média & Alta \\
\hline II & Alta & II & Alta & Alta \\
\hline
\end{tabular}

O SIF abaixo possui três variáveis de entrada: a saída do SIF de segundo nível composta por Cuidados e Advertências, Fatores de Interface de Hardware, Métodos de Trabalho, Políticas da Planta, Feedback (Conhecimento de Resultados), e Procedimentos (Escritos ou Não Escritos); a saída do SIF de primeiro nível composta por Disponibilidade de Equipamentos Especiais, Instrumentos, e Insumos; e a possibilidade de erro de Ação parcial devida à Qualidade do Ambiente. Contudo, a primeira variável de entrada citada possui três PSF indiferentes, sendo representada então apenas pelos PSFs Cuidados e Advertências, Fatores de Interface de Hardware, e Procedimentos (Escritos ou Não Escritos). 
Não possuir o equipamento necessário impede a realização da tarefa, como por exemplo: imprimir relatórios sem ter a impressora, enviar um email sem ter internet, revisar documentação sem ter a documentação.

\begin{tabular}{|c|c|c|c|c|c|c|}
\hline $\begin{array}{c}\text { Cuidados e Advertências } \\
\text { Fatores de Interface de } \\
\text { Hardware }\end{array}$ & $\begin{array}{c}\text { Disponibilidade } \\
\text { de Equipamentos } \\
\text { Especiais }\end{array}$ & & Alta & $\begin{array}{c}\text { Qualidade } \\
\text { do Ambiente }\end{array}$ & $*$ & Alta \\
$\begin{array}{c}\text { Políticas da Planta } \\
\text { Feedback (Conhecimento } \\
\text { de Resultados) } \\
\begin{array}{c}\text { Procedimentos (Escritos } \\
\text { ou Não Escritos) }\end{array}\end{array}$ & $*$ & Instrumentos & & & & \\
\hline
\end{tabular}

Por mais que a Qualidade do Ambiente esteja boa e todos os equipamentos necessários estejam à disposição, o funcionário não será capaz de executar a tarefa com sucesso se for negligente para com os Cuidados e Advertências, não entender os Fatores de Interfaces de Hardware, e desconhecer os Procedimentos corretos.

\begin{tabular}{|c|c|c|c|c|c|c|}
\hline $\begin{array}{c}\text { Cuidados e Advertências } \\
\text { Fatores de Interface de } \\
\text { Hardware }\end{array}$ & $\begin{array}{c}\text { Disponibilidade } \\
\text { de Equipamentos } \\
\text { Especiais }\end{array}$ \\
$\left.\begin{array}{c}\text { Métodos de Trabalho } \\
\text { Políticas da Planta } \\
\begin{array}{c}\text { Feedback (Conhecimento } \\
\text { de Resultados) } \\
\begin{array}{c}\text { Procedimentos (Escritos } \\
\text { ou Não Escritos) }\end{array}\end{array}\end{array}\right)$ Alta & $*$ & $\begin{array}{c}\text { Qualidade do } \\
\text { Ambiente }\end{array}$ & $*$ & Alta \\
\hline
\end{tabular}

Caso os PSFs Cuidados e Advertências, Fatores de Interface de Hardware, e Procedimentos (Escritos ou Não Escritos) estejam indicando Baixa possibilidade de erro de $A c ̧ \tilde{a} o$ :

\begin{tabular}{|c|c|c|c|c|}
\hline $\begin{array}{c}\text { Disponibilidade de } \\
\text { Equipamentos Especiais }\end{array}$ & Baixa & Qualidade do Ambiente & Baixa & Baixa \\
\hline $\begin{array}{c}\text { Instrumentos } \\
\text { Insumos }\end{array}$ & & & & \\
\hline II & Baixa & II & Média & Baixa \\
\hline II & Baixa & II & Alta & Média \\
\hline$I I$ & Média & II & Baixa & Média \\
\hline II & Média & II & Média & Média \\
\hline$I I$ & Média & II & Alta & Média \\
\hline
\end{tabular}


E caso estejam indicando Média possibilidade de erro de Ação:

\begin{tabular}{|c|c|c|c|c|}
\hline $\begin{array}{c}\text { Disponibilidade de } \\
\text { Equipamentos Especiais } \\
\text { Instrumentos } \\
\text { Insumos }\end{array}$ & Baixa & Qualidade do Ambiente & Baixa & Média \\
\hline II & Baixa & II & Média & Média \\
\hline II & Baixa & II & Alta & Média \\
\hline II & Média & II & Baixa & Média \\
\hline II & Média & II & Média & Média \\
\hline II & Média & II & Alta & Alta \\
\hline
\end{tabular}

No SIF abaixo, para a etapa $A c ̧ \tilde{a} o$ o sub-grupo da esquerda (fatores de stress fisiológicos) é imprescindível, qualquer PSF mal desempenhado irá causar um erro, porém, algumas tarefas não exigem nenhuma característica física, fazendo com que automaticamente a entrada dessas variáveis indiquem o valor "don't care". Esta diferenciação será feita no capítulo seguinte.

Supondo que a tarefa não descarte a necessidade do bom desempenho dos PSFs pertencentes ao Grupo de PSFs Fatores de Stress Fisiológicos, caso Exercício Físico estiver precário, Fadiga estiver Alta, o funcionário estiver com Fome ou Sede, e estiver tendo problemas com sua rotina de relógio biológico, ocorrerá o erro de Ação, ainda que seus sentidos estejam funcionando corretamente e ele não esteja distraído.

\begin{tabular}{|c|c|c|c|c|c|c|}
\hline $\begin{array}{l}\text { Exercício Físico } \\
\text { Fadiga } \\
\text { Fome ou Sede } \\
\text { Interrupção do } \\
\text { Ritmo Circadiano }\end{array}$ & Alta & $\begin{array}{l}\text { Distrações (devido a } \\
\text { Ruído, Clarão, } \\
\text { Movimentos, etc.) } \\
\text { Perda de Sensibilidade }\end{array}$ & $*$ & $\begin{array}{c}\text { Trabalho em } \\
\text { Alturas }\end{array}$ & $*$ & Alta \\
\hline
\end{tabular}

Analogamente, por melhor que seja o preparo físico do colaborador, bem como sua alimentação e rotina, o erro de Ação ocorrerá se seu nível de Distração estiver Alto. 


\begin{tabular}{|c|l|c|c|c|c|c|}
\hline Exercício Físico & & $\begin{array}{c}\text { Distrações (devido a } \\
\text { Ruído, Clarão, } \\
\text { Movimentos, etc.) }\end{array}$ & Alta & $\begin{array}{c}\text { Trabalho em } \\
\text { Alturas }\end{array}$ & $*$ & Alta \\
$\begin{array}{c}\text { Fome ou Sede } \\
\text { Interrupção do } \\
\text { Ritmo Circadiano }\end{array}$ & $*$ & Perda de Sensibilidade & & & & \\
\hline
\end{tabular}

Para os demais casos, se a saída do SIF de segundo nível composto pelos PSFs Exercício Físico, Fadiga, Fome ou Sede, e Interrupção do Ritmo Circadiano

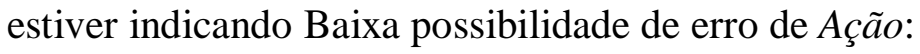

\begin{tabular}{|c|c|c|c|c|}
\hline $\begin{array}{c}\text { Distrações (devido a Ruído, } \\
\text { Clarão, M ovimentos, etc.) } \\
\text { Perda de Sensibilidade }\end{array}$ & Baixa & Trabalho em Alturas & Baixa & Baixa \\
\hline II & Baixa & II & Média & Baixa \\
\hline II & Baixa & II & Alta & Baixa \\
\hline II & Média & II & Baixa & Média \\
\hline II & Média & II & Média & Média \\
\hline II & Média & II & Alta & Média \\
\hline
\end{tabular}

E se indicar Média possibilidade de erro de Ação:

\begin{tabular}{|c|c|c|c|c|}
\hline $\begin{array}{c}\text { Distrações (devido a Ruído, } \\
\text { Clarão, M ovimentos, etc.) } \\
\text { Perda de Sensibilidade }\end{array}$ & Alta & Trabalho em Alturas & $*$ & Alta \\
\hline$I I$ & Baixa & II & Baixa & Média \\
\hline$I I$ & Baixa & II & Média & Média \\
\hline$I I$ & Baixa & II & Alta & Média \\
\hline II & Média & II & Baixa & Média \\
\hline$I I$ & Média & II & Média & Média \\
\hline$I I$ & Média & II & Alta & Alta \\
\hline
\end{tabular}

O SIF abaixo relaciona criticidade da tarefa com pausas e descansos. Um caso interessante de se observar é o de uma dada tarefa ter freqüência de ocorrência Alta, sendo muito repetitiva, com pouco pessoal e rodízio de turnos raro, a possibilidade de um erro de Ação poderá ser amenizada se tal tarefa for extremamente simples e não crítica. 


\begin{tabular}{|c|c|c|c|c|}
\hline $\begin{array}{c}\text { Capacidade Crítica da } \\
\text { Tarefa }\end{array}$ & Baixa & $\begin{array}{c}\text { Freqüência e } \\
\text { Repetitividade da Tarefa } \\
\text { Horas de Trabalho / } \\
\text { Intervalos de Trabalho } \\
\text { Quantidade de Pessoal } \\
\text { (Carga de Informações) }\end{array}$ & Baixa de Turnos & Baixa \\
\hline II & Baixa & II & Média & Baixa \\
\hline II & Baixa & II & Alta & Média \\
\hline II & Média & II & Baixa & Baixa \\
\hline II & Média & II & M édia & Média \\
\hline II & Média & II & Alta & Alta \\
\hline II & Alta & II & Baixa & Média \\
\hline II & Alta & II & Média & Média \\
\hline II & Alta & II & Alta & Alta \\
\hline
\end{tabular}

Este SIF avalia conjuntamente a vontade de realizar a tarefa de maneira polida, correta, eficiente com o conhecimento que o funcionário tem das diferentes e melhores maneiras de fazê-lo. Caso ambas características estiverem sendo bem desempenhadas, o erro de Ação não ocorrerá, por outro lado se uma delas estiver aquém do necessário, a outra não terá sua capacidade aproveitada. Ainda que o funcionário tenha o conhecimento, não terá sucesso na efetiva execução se estiver desleixado. Da mesma forma que se o funcionário tem vontade de executar a tarefa da melhor maneira possível, poderá fracassar caso lhe falte o conhecimento necessário (o que poderia ter sido corrigido se lhe fosse proporcionado um melhor treinado, ou tivesse estudado melhor a cultura de segurança e organizacional da empresa).

\begin{tabular}{|c|c|c|c|c|}
\hline $\begin{array}{c}\text { Desempenho } \\
\text { Dominância }\end{array}$ & Baixa & $\begin{array}{c}\text { Conhecimento de Padrões } \\
\text { de Desempenho } \\
\text { Experiência } \\
\text { Nível de cultura de } \\
\text { segurança } \\
\text { Nível de cultura organiz. } \\
\text { Nível de práticas } \\
\text { Qualidade do Treinamento }\end{array}$ & Baixa & Baixa \\
\hline Persistência & Baixa & II & Média & Média \\
\hline II & Baixa & II & Alta & Média \\
\hline II & Média & II & Baixa & Baixa \\
\hline II & Média & II & Média & Média \\
\hline II & Média & II & Alta & Alta \\
\hline II & Alta & II & Baixa & Média \\
\hline II & Alta & II & Média & Alta \\
\hline II & Alta & II & Alta & Alta \\
\hline II & &
\end{tabular}


Ainda que exerça influência direta sobre a Ação, o PSF Denegação não é tão importante quanto os PSFs de Fatores Externos que influenciam a capacidade de concentração do funcionário, fazendo com que o peso destes seja maior do que o daquele neste SIF. Isto é, tensão física e mental, assim como saúde e motivação são muito mais críticos do que o sentimento de inferioridade. Por outro lado, se o funcionário possuir personalidade que valorize a negação de sua própria opinião, é esperado que sua motivação seja abalada mais facilmente, assim como a influência de outras pessoas seja mais impactante para ele.

\begin{tabular}{|c|c|c|c|c|}
\hline $\begin{array}{c}\text { Condição Física/Saúde } \\
\text { Influência de outros } \\
\text { agentes externos (pessoas, } \\
\text { família) } \\
\text { M otivação } \\
\text { Tensão Mental ou Física }\end{array}$ & Baixa & Denegação & Baixa & Baixa \\
\hline II & Baixa & II & Média & Baixa \\
\hline II & Baixa & II & Alta & Média \\
\hline II & Média & II & Baixa & Média \\
\hline II & Média & II & Média & Média \\
\hline II & Média & II & Alta & Alta \\
\hline II & Alta & II & $*$ & Alta \\
\hline
\end{tabular}

Como os PSFs Agressão e Autonomia não influenciam diretamente a Ação, a outra variável de entrada tem maior importância para este SIF de terceiro nível.

\begin{tabular}{|c|c|c|c|c|}
\hline Afago & Baixa & $\begin{array}{c}\text { Períodos de Vigilância } \\
\text { Longos, sem } \\
\text { Acontecimentos } \\
\text { Trabalho M onótono, } \\
\text { Afiliação } \\
\text { Agressão } \\
\text { Autonomiante ou Sem Sentido } \\
\text { Reforço Negativo } \\
\text { Sugestões Inconsistentes }\end{array}$ & Baixa & Baixa \\
\hline II & Baixa & II & Média & M édia \\
\hline II & Baixa & II & Alta & M édia \\
\hline II & M édia & II & Baixa & Baixa \\
\hline II & M édia & II & Média & Média \\
\hline II & M édia & II & Alta & Alta \\
\hline II & Alta & II & Baixa & Média \\
\hline II & Alta & II & Média & Média \\
\hline II & Alta & II & Alta & Alta \\
\hline
\end{tabular}

Enquanto os PSFs Assistência e Deferência exercem influência apenas indireta na Ação, o PSF Mudança tem grande impacto: gostar de alterar, no 
momento da execução da tarefa, o que foi planejado anteriormente pode culminar em erro, seja por falta de tempo para se avaliar cuidadosamente todos os parâmetros pertinentes, ou por não informar todos os membros da equipe envolvidos, ou ainda por imprudentemente esquecer algum procedimento.

\begin{tabular}{|c|c|c|c|c|}
\hline $\begin{array}{c}\text { Assistência } \\
\text { Deferência } \\
\text { Exibição } \\
\text { Intracepção }\end{array}$ & Baixa & Mudança & Baixa & Baixa \\
\hline II & Baixa & II & Média & Baixa \\
\hline II & Baixa & II & Alta & Média \\
\hline II & Média & II & Baixa & Baixa \\
\hline II & Média & II & Média & Média \\
\hline II & Média & II & Alta & Alta \\
\hline II & Alta & II & Baixa & Média \\
\hline II & Alta & II & Média & Alta \\
\hline II & Alta & II & Alta & Alta \\
\hline
\end{tabular}

\subsubsection{4.}

\section{SIFs Hierárquicos do Quarto Nível}

Novamente, caso os fatores de stress fisiológicos englobados por este SIF sejam necessários para a tarefa, seu bom desempenho será vital para o sucesso da mesma.

\begin{tabular}{|c|c|c|c|c|}
\hline $\begin{array}{c}\text { Se possibilidade de erro de } \\
\text { Informação do Sub-grupo }\end{array}$ & é & $\begin{array}{c}\text { Então } \\
\text { e possibilidade de erro de } \\
\text { Informação do Sub-grupo } \\
\text { Dor ou Desconforto } \\
\text { Longa Duração do Stress } \\
\text { Repetição de M ovimentos } \\
\text { de erro de } \\
\text { Ação é }\end{array}$ \\
\hline $\begin{array}{c}\text { Alta Velocidade na } \\
\text { Execução da Tarefa }\end{array}$ & Baixa & $\begin{array}{c}\text { Capacidade Crítica da } \\
\text { Tarefa } \\
\text { Complexidade da Tarefa } \\
\text { (Carga de Informações) } \\
\text { Freqüência e } \\
\text { Repetitividade da Tarefa } \\
\text { Horas de Trabalho / } \\
\text { Intervalos de Trabalho } \\
\text { Quantidade de Pessoal } \\
\text { Rodízio de Turnos }\end{array}$ & Baixa & Baixa \\
\hline II & Baixa & II & Média & Média \\
\hline II & Baixa & II & Alta & Média \\
\hline II & Média & II & Baixa & Média \\
\hline II & Média & II & Média & Média \\
\hline II & Média & II & Alta & Alta \\
\hline II & Alta & II & $*$ & Alta \\
\hline
\end{tabular}


Como o SIF abaixo possui três variáveis de entrada, suas regras foram separadas em três para permitir sua melhor exibição.

Caso o SIF de terceiro nível composto pelos PSFs Ameaças (de Falha, de Perda do Emprego, etc.); Falta de Recompensas, Reconhecimento e Benefícios; Motivos Conflitantes sobre o Desempenho no Trabalho; Carga Pesada de Informações; Início Inesperado do Stress; Ações desenvolvidas por Supervisores, Colegas, Representantes de Sindicatos, e Pessoal de Regulamentação; Comunicação; Estrutura de Equipe; e Estrutura Organizacional esteja indicando Baixa possibilidade de erro de Ação:

Não há motivo para executar a tarefa erroneamente se a comunicação está ok: apesar de não gostar ou não se identificar com sua equipe, não há problemas que impedirão o bom funcionamento do grupo.

\begin{tabular}{|c|c|c|c|c|}
\hline 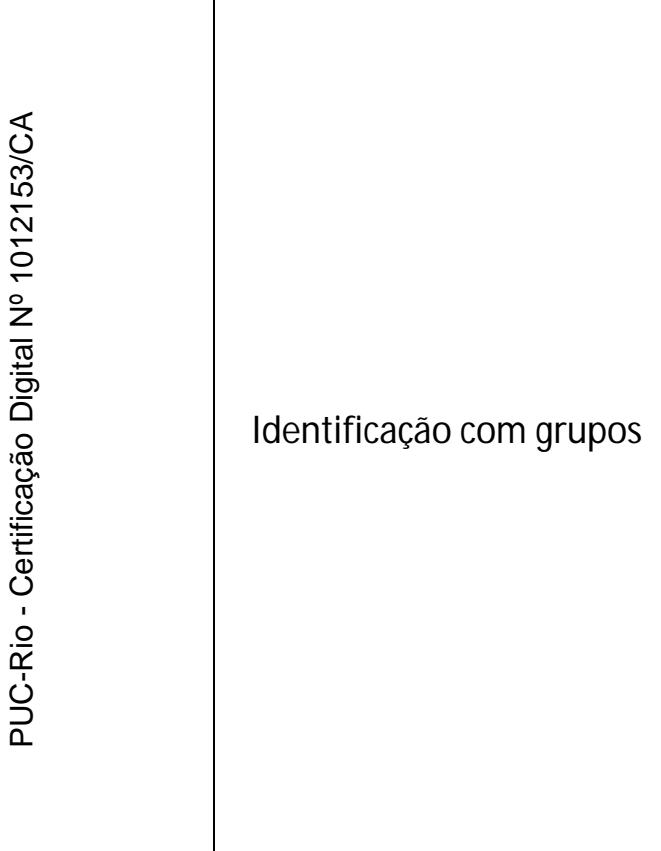 & Baixa & $\begin{array}{c}\text { Afago } \\
\text { Afiliação } \\
\text { Agressão } \\
\text { Autonomia } \\
\text { Períodos de Vigilância } \\
\text { Longos, sem } \\
\text { Acontecimentos } \\
\text { Trabalho M onótono, } \\
\text { Degradante ou Sem } \\
\text { Sentido } \\
\text { Reforço Negativo } \\
\text { Sugestões Inconsistentes }\end{array}$ & Baixa & Baixa \\
\hline II & Baixa & II & Média & Baixa \\
\hline II & Baixa & II & Alta & Baixa \\
\hline II & Média & II & Baixa & Baixa \\
\hline II & Média & II & Média & Média \\
\hline II & Média & II & Alta & M édia \\
\hline II & Alta & II & Baixa & Baixa \\
\hline II & Alta & II & Média & M édia \\
\hline II & Alta & II & Alta & Média \\
\hline
\end{tabular}

Caso o SIF de terceiro nível que contém o PSFs Ameaças (de Falha, de Perda do Emprego, etc.) indique Média possibilidade de erro de Ação: 
Apesar de se identificar com o grupo, a Comunicação está parcialmente prejudicada, se concomitantemente estiver ocorrendo Reforço Negativo e Sugestões Inconsistentes, a possibilidade de um erro de ação acontecer será Alta, principalmente se o funcionário estiver desempenhando uma função que julgue ser monótona.

\begin{tabular}{|c|c|c|c|c|}
\hline Identificação com grupos & Baixa & $\begin{array}{c}\text { Afago / Afiliação / Agressão } \\
\text { / Autonomia / Períodos } \\
\text { sem Acontecimentos / } \\
\text { Trabalho M onótono / } \\
\text { Reforço Negativo / } \\
\text { Sugestões Inconsistentes }\end{array}$ & Baixa & M édia \\
\hline II & Baixa & II & Média & M édia \\
\hline II & Baixa & II & Alta & Alta \\
\hline II & Média & II & Baixa & M édia \\
\hline II & Média & II & Média & M édia \\
\hline II & Média & II & Alta & Alta \\
\hline II & Alta & II & Baixa & M édia \\
\hline II & Alta & II & Média & Alta \\
\hline II & Alta & II & Alta & Alta \\
\hline
\end{tabular}

Por fim, caso de terceiro nível que contém o PSFs Ameaças (de Falha, de Perda do Emprego, etc.) indique Alta possibilidade de erro de Ação, as demais variáveis de entrada deste SIF de quarto nível não serão capazes por si só de garantir o sucesso da tarefa.

\begin{tabular}{|c|c|c|c|c|}
\hline Identificação com grupos & $*$ & $\begin{array}{l}\text { Afago / Afiliação / Agressão } \\
\text { / Autonomia / Períodos sem } \\
\text { Acontecimentos / Trabalho } \\
\text { M onótono / Reforço } \\
\text { Negativo / Sugestões } \\
\text { Inconsistentes }\end{array}$ & $*$ & Alta \\
\hline
\end{tabular}

Ainda que o ambiente esteja ruim, não exista sinalização de como proceder ou com o que tomar cuidado, o erro de Ação pode ser evitado se o funcionário tiver sido bem treinamento, conhecer os padrões de desempenho, possuir experiência, for organizado e primar por realizar o trabalho de maneira bem feita. 


\begin{tabular}{|c|c|c|c|c|}
\hline $\begin{array}{c}\text { Cuidados e Advertências } \\
\text { Fatores de Interface de } \\
\text { Hardware } \\
\text { Métodos de Trabalho } \\
\text { Políticas da Planta } \\
\text { Feedback (Conhecimento } \\
\text { de Resultados) } \\
\text { Procedimentos (Escritos ou } \\
\text { Não Escritos) } \\
\text { Qualidade do Ambiente }\end{array}$ & Baixa & $\begin{array}{c}\text { Desempenho } \\
\text { Dominância } \\
\text { Ordem } \\
\text { Persistência } \\
\text { Conhecimento de Padrões } \\
\text { de Desempenho } \\
\text { Experiência } \\
\text { Nível de cultura de } \\
\text { segurança } \\
\text { Nível de cultura } \\
\text { organizacional } \\
\text { Nível de práticas } \\
\text { Qualidade do Treinamento }\end{array}$ & Baixa & Baixa \\
\hline II & Baixa & II & Média & Média \\
\hline II & Baixa & II & Alta & Média \\
\hline II & Média & II & Baixa & Baixa \\
\hline II & Média & II & Média & Média \\
\hline II & Média & II & Alta & Alta \\
\hline II & Alta & II & Baixa & Média \\
\hline II & Alta & II & Média & Alta \\
\hline II & Alta & II & Alta & Alta \\
\hline
\end{tabular}


Espera-se que na prática (assim como no estudo de caso do capítulo seguinte) que ambas variáveis de entrada deste SIF tenham desempenho similar, uma vez que não é coerente possuir condição física ruim e exercício físico bom. Mesmo que se tratasse de um colaborador que tenha bom condicionamento físico passando por uma recuperação, ou questão de saúde, essas condições fariam com que Perda de Sensibilidade estivesse indicando Alta possibilidade de erro, bem como a Interrupção do Ritmo Circadiano.

\begin{tabular}{|c|c|c|c|c|}
\hline $\begin{array}{c}\text { Exercício Físico } \\
\text { Fadiga } \\
\text { Fome ou Sede } \\
\text { Interrupção do Ritmo } \\
\text { Circadiano } \\
\text { Distrações (devido a } \\
\text { Ruído, Clarão, } \\
\text { Movimentos, etc.) } \\
\text { Perda de Sensibilidade } \\
\text { Trabalho em Alturas }\end{array}$ & Baixa & $\begin{array}{c}\text { Condição Física/Saúde } \\
\text { Influência de outros agentes } \\
\text { externos (pessoas, família) } \\
\text { M otivação } \\
\text { Tensão M ental ou Física } \\
\text { Denegação }\end{array}$ & Baixa & Baixa \\
\hline II & Baixa & II & Média & Média \\
\hline II & Baixa & II & Alta & Média \\
\hline II & Média & II & Baixa & Baixa \\
\hline II & Média & II & Média & Média \\
\hline II & Média & II & Alta & Alta \\
\hline II & Alta & II & Baixa & Média \\
\hline II & Alta & II & Média & Alta \\
\hline II & Alta & II & Alta & Alta \\
\hline
\end{tabular}


3.4.3.5.

SIFs Hierárquicos do Quinto Nível

\begin{tabular}{|c|c|c|c|c|}
\hline $\begin{array}{c}\text { Se possibilidade de erro } \\
\text { de Informação do Sub- } \\
\text { grupo }\end{array}$ & é & $\begin{array}{l}\text { e possibilidade de erro de } \\
\text { Informação do Sub-grupo }\end{array}$ & é & $\begin{array}{c}\text { Então } \\
\text { possibilidade } \\
\text { de erro de } \\
\text { Ação é }\end{array}$ \\
\hline $\begin{array}{c}\text { Constrição de } \\
\text { Movimentos } \\
\text { Dor ou Desconforto } \\
\text { Longa Duração do } \\
\text { Stress } \\
\text { Repetição de } \\
\text { Movimentos } \\
\text { Alta Velocidade na } \\
\text { Execução da Tarefa } \\
\text { Capacidade Crítica da } \\
\text { Tarefa } \\
\text { Complexidade da Tarefa } \\
\text { (Carga de Informações) } \\
\text { Freqüência e } \\
\text { Repetitividade da } \\
\text { Tarefa } \\
\text { Horas de Trabalho / } \\
\text { Intervalos de Trabalho } \\
\text { Quantidade de Pessoal } \\
\text { Rodízio de Turnos }\end{array}$ & Baixa & $\begin{array}{c}\text { Exercício Físico } \\
\text { Fadiga } \\
\text { Fome ou Sede } \\
\text { Interrupção do Ritmo } \\
\text { Circadiano } \\
\text { Distrações (devido a Ruído, } \\
\text { Clarão, M ovimentos, etc.) } \\
\text { Perda de Sensibilidade } \\
\text { Trabalho em Alturas } \\
\text { Condição Física/Saúde } \\
\text { Influência de outros agentes } \\
\text { externos (pessoas, família) } \\
\text { M otivação } \\
\text { Tensão M ental ou Física } \\
\text { Denegação }\end{array}$ & Baixa & Baixa \\
\hline II & Baixa & II & Média & Média \\
\hline II & Baixa & II & Alta & Média \\
\hline II & Média & II & Baixa & Média \\
\hline II & Média & II & Média & Média \\
\hline II & Média & II & Alta & Alta \\
\hline II & Alta & II & Baixa & Média \\
\hline II & Alta & II & Média & Alta \\
\hline II & Alta & II & Alta & Alta \\
\hline
\end{tabular}




\begin{tabular}{|c|c|c|c|c|}
\hline $\begin{array}{c}\text { Cuidados e Advertências } \\
\text { Fatores de Interface de } \\
\text { Hardware } \\
\text { Métodos de Trabalho } \\
\text { Políticas da Planta } \\
\text { Feedback (Conhecimento } \\
\text { de Resultados) } \\
\text { Procedimentos (Escritos ou } \\
\text { Não Escritos) } \\
\text { Qualidade do Ambiente } \\
\text { Desempenho } \\
\text { Dominância } \\
\text { Ordem } \\
\text { Persistência } \\
\text { Conhecimento de Padrões } \\
\text { de Desempenho } \\
\text { Experiência } \\
\text { Nível de cultura de } \\
\text { segurança } \\
\text { Nível de cultura } \\
\text { organizacional } \\
\text { Nível de práticas } \\
\text { Qualidade do Treinamento }\end{array}$ & Baixa & $\begin{array}{l}\text { Continuidade de matrizes } \\
\text { ou conjuntos }\end{array}$ & Baixa & Baixa \\
\hline II & Baixa & II & Média & Baixa \\
\hline II & Baixa & II & Alta & Baixa \\
\hline II & Média & II & Baixa & Média \\
\hline II & Média & II & Média & Média \\
\hline II & Média & II & Alta & Alta \\
\hline II & Alta & II & $*$ & Alta \\
\hline
\end{tabular}




\begin{tabular}{|c|c|c|c|c|}
\hline $\begin{array}{l}\text { Ameaças (de Falha, de } \\
\text { Perda do Emprego, etc.) } \\
\text { Falta de Recompensas, } \\
\text { Reconhecimento e } \\
\text { Benefícios } \\
\text { Motivos Conflitantes sobre } \\
\text { o Desempenho no Trabalho } \\
\text { Carga Pesada de } \\
\text { Informações } \\
\text { Início Inesperado do Stress } \\
\text { Ações desenvolvidas por } \\
\text { Supervisores, Colegas, } \\
\text { Representantes de } \\
\text { Sindicatos, e Pessoal de } \\
\text { Regulamentação } \\
\text { Comunicação } \\
\text { Estrutura de Equipe } \\
\text { Estrutura Organizacional } \\
\text { Identificação com grupos } \\
\text { Afago } \\
\text { Afiliação } \\
\text { Agressão } \\
\text { Autonomia } \\
\text { Períodos de Vigilância } \\
\text { Longos, sem } \\
\text { Acontecimentos } \\
\text { Trabalho M onótono, } \\
\text { Degradante ou Sem } \\
\text { Sentido } \\
\text { Reforço Negativo } \\
\text { Sugestões Inconsistentes }\end{array}$ & Baixa & $\begin{array}{l}\text { Intracepção } \\
\text { Mudança }\end{array}$ & Baixa & Baixa \\
\hline II & Baixa & II & Média & Baixa \\
\hline II & Baixa & II & Alta & Baixa \\
\hline II & Média & II & Baixa & Média \\
\hline II & Média & II & Média & Média \\
\hline II & Média & II & Alta & Alta \\
\hline II & Alta & II & $*$ & Alta \\
\hline
\end{tabular}

\subsubsection{6.}

\section{SIF Hierárquico do Sexto Nível}

Este SIF avalia a junção dos PSFs relativos ao ambiente que circunda o funcionário, e aos seus conhecimentos sobre a empresa com os principais fatores cognitivos, permitindo que a contextualização de suas capacidades seja feita. 


\begin{tabular}{|c|c|c|c|c|}
\hline $\begin{array}{c}\text { Se possibilidade de erro } \\
\text { de Informação do Sub- } \\
\text { grupo }\end{array}$ & é & $\begin{array}{l}\text { e possibilidade de erro de } \\
\text { Informação do Sub-grupo }\end{array}$ & é & $\begin{array}{c}\text { Então } \\
\text { possibilidade } \\
\text { de erro de } \\
\text { Ação é }\end{array}$ \\
\hline $\begin{array}{c}\text { Cuidados / Fatores de } \\
\text { Interface / Métodos de } \\
\text { Trabalho / Políticas da } \\
\text { Planta / Feedback / } \\
\text { Procedimentos / } \\
\text { Qualidade do Ambiente / } \\
\text { Desempenho / } \\
\text { Dominância / Ordem / } \\
\text { Persistência / } \\
\text { Conhecimento de Padrões } \\
\text { / Experiência / Cultura de } \\
\text { segurança / Cultura } \\
\text { organizacional / Práticas / } \\
\text { Qualidade do } \\
\text { Treinamento / } \\
\text { Continuidade de matrizes } \\
\text { ou conjuntos / } \\
\text { Estruturação do campo } \\
\text { perceptivo (topologia) }\end{array}$ & Baixa & $\begin{array}{c}\text { Capacidade de } \\
\text { Classificação } \\
\text { Capacidade de } \\
\text { Antecipação } \\
\text { Capacidade de Tomada de } \\
\text { Decisões } \\
\text { Inteligência numérica } \\
\text { (capacidade de cálculos) } \\
\text { Percepção de séries } \\
\text { Memória } \\
\text { Predisposição para novos } \\
\text { conhecimentos }\end{array}$ & Baixa & Baixa \\
\hline II & Baixa & II & Média & M édia \\
\hline II & Baixa & II & Alta & Média \\
\hline II & M édia & II & Baixa & M édia \\
\hline II & M édia & II & Média & Média \\
\hline II & Média & II & Alta & Alta \\
\hline II & Alta & II & Baixa & Média \\
\hline II & Alta & II & Média & Alta \\
\hline II & Alta & II & Alta & Alta \\
\hline
\end{tabular}

\subsubsection{7.}

\section{SIF Hierárquico do Sétimo Nível}

No que diz respeito às características pertinentes à etapa de $A c ̧ a \tilde{o}$, a variável de entrada exposta na primeira coluna do SIF abaixo representa o conhecimento, as habilidades e a perícia, enquanto a outra variável é representativa do nível de nervosismo e de quão propício a deslizes está o funcionário. 


\begin{tabular}{|c|c|c|c|c|}
\hline $\begin{array}{l}\text { Se possibilidade de erro de } \\
\text { Informação do Sub-grupo }\end{array}$ & é & $\begin{array}{l}\text { e possibilidade de } \\
\text { erro de Informação } \\
\text { do Sub-grupo }\end{array}$ & é & $\begin{array}{c}\text { Então } \\
\text { possibilidade } \\
\text { de erro de } \\
\text { Ação é }\end{array}$ \\
\hline $\begin{array}{c}\text { Cuidados / Fatores de } \\
\text { Interface / M étodos de } \\
\text { Trabalho / Políticas da Planta } \\
\text { / Feedback / Procedimentos / } \\
\text { Qualidade do Ambiente / } \\
\text { Desempenho / Dominância / } \\
\text { Ordem / Persistência / } \\
\text { Conhecimento de Padrões / } \\
\text { Experiência / Cultura de } \\
\text { segurança / Cultura } \\
\text { organizacional / Práticas / } \\
\text { Qualidade do Treinamento / } \\
\text { Continuidade de matrizes ou } \\
\text { conjuntos / Estruturação do } \\
\text { campo perceptivo (topologia) } \\
\text { / Capacidade Analítica / } \\
\text { Capacidade de Classificação / } \\
\text { Capacidade de Antecipação / } \\
\text { Capacidade de Tomada de } \\
\text { Decisões / Inteligência } \\
\text { numérica / Percepção de } \\
\text { séries / M emória / } \\
\text { Predisposição para novos } \\
\text { conhecimentos }\end{array}$ & Baixa & $\begin{array}{c}\text { Ameaças / Falta de } \\
\text { Reconhecimento / } \\
\text { Motivos Conflitantes / } \\
\text { Carga Pesada de } \\
\text { Informações / Início } \\
\text { Inesperado do Stress / } \\
\text { Ações desenvolvidas } \\
\text { por Sup. / } \\
\text { Comunicação / } \\
\text { Estrutura de Equipe / } \\
\text { Estrutura } \\
\text { Organizacional / } \\
\text { Identificação com } \\
\text { grupos / Afago / } \\
\text { Afiliação / Agressão / } \\
\text { Autonomia / Períodos } \\
\text { sem Acontecimentos / } \\
\text { Trabalho M onótono / } \\
\text { Reforço Negativo / } \\
\text { Sugestões } \\
\text { Inconsistentes / } \\
\text { Assistência / } \\
\text { Deferência / Mudança }\end{array}$ & Baixa & Baixa \\
\hline II & Baixa & II & Média & Baixa \\
\hline II & Baixa & II & Alta & Média \\
\hline II & Média & II & Baixa & Média \\
\hline II & Média & II & Média & Média \\
\hline II & Média & II & Alta & Alta \\
\hline II & Alta & II & $*$ & Alta \\
\hline
\end{tabular}

\subsubsection{8.}

\section{SIF Hierárquico do Oitavo Nível}

Este SIF de oitavo nível é responsável por avaliar como fatores de personalidade e de conhecimento adquirido (que demandam maior tempo para serem alterados) influenciam no comportamento do funcionário diante de diferentes fatores situacionais, que podem ser alterados a cada variação de contexto. 


\begin{tabular}{|c|c|c|c|c|}
\hline $\begin{array}{l}\text { Se possibilidade de erro de } \\
\text { Informação do Sub-grupo }\end{array}$ & é & $\begin{array}{l}\text { e possibilidade de } \\
\text { erro de Informação } \\
\text { do Sub-grupo }\end{array}$ & é & $\begin{array}{c}\text { Então } \\
\text { possibilidade } \\
\text { de erro de } \\
\text { Ação é }\end{array}$ \\
\hline $\begin{array}{c}\text { Cuidados / Fatores de Interface / } \\
\text { M étodos de Trabalho / Políticas da } \\
\text { Planta / Feedback / Procedimentos / } \\
\text { Qualidade do Ambiente / } \\
\text { Desempenho / Dominância / Ordem } \\
\text { / Persistência / Conhecimento de } \\
\text { Padrões / Experiência / Cultura de } \\
\text { segurança / Cultura organizacional / } \\
\text { Práticas / Qualidade do Treinamento } \\
\text { / Continuidade de matrizes ou } \\
\text { conjuntos / Estruturação do campo } \\
\text { perceptivo (topologia) / Capacidade } \\
\text { Analítica / Capacidade de } \\
\text { Classificação / Capacidade de } \\
\text { Antecipação / Capacidade de } \\
\text { Tomada de Decisões / Inteligência } \\
\text { numérica / Percepção de séries / } \\
\text { Memória / Predisposição para novos } \\
\text { conhecimentos / Ameaças / Falta de } \\
\text { Reconhecimento / M otivos } \\
\text { Conflitantes / Carga Pesada de } \\
\text { Informações / Início Inesperado do } \\
\text { Stress / Ações desenvolvidas por } \\
\text { Sup. / Comunicação / Estrutura de } \\
\text { Equipe Estrutura Organizacional / } \\
\text { Identificação com grupos / Afago / } \\
\text { Afiliação / Agressão / Autonomia / } \\
\text { Períodos sem Acontecimentos / } \\
\text { Trabalho M onótono / Reforço } \\
\text { Negativo / Sugestões Inconsistentes } \\
\text { / Assistência / Deferência / M udança }\end{array}$ & Baixa & $\begin{array}{l}\text { Constrição de } \\
\text { M ovimentos / Dor } \\
\text { ou Desconforto / } \\
\text { Longa duração do } \\
\text { Stress / Repetição } \\
\text { de M ov. / Alta } \\
\text { Velocidade na } \\
\text { Execução / } \\
\text { Capacidade Crítica / } \\
\text { Complexidade / } \\
\text { Repetitividade / } \\
\text { Intervalos / } \\
\text { Quantidade de } \\
\text { Pessoal / Turnos / } \\
\text { Exercício Físico / } \\
\text { Fadiga / Fome ou } \\
\text { Sede / Int. Ritmo } \\
\text { Circ. / Distrações / } \\
\text { Perda de } \\
\text { Sensibilidade / } \\
\text { Trabalho em Alturas } \\
\text { / Condição } \\
\text { Física/ Saúde / } \\
\text { Agentes externos / } \\
\text { Motivação / Tensão } \\
\text { M ental ou Física / } \\
\text { Denegação }\end{array}$ & Baixa & Baixa \\
\hline II & Baixa & II & Média & Baixa \\
\hline II & Baixa & II & Alta & Média \\
\hline II & Média & II & Baixa & Média \\
\hline II & Média & II & Média & Média \\
\hline II & Média & II & Alta & Alta \\
\hline II & Alta & II & $*$ & Alta \\
\hline
\end{tabular}

\subsubsection{9.}

\section{SIF Hierárquico do Nono Nível}

A grande importância do PSF Nível de Atenção para a etapa Ação é devido ao fato de que lapsos e deslizes podem ocorrer a qualquer momento, se pouca 
atenção estiver sendo dedicada ao trabalho que se está desempenhando. Caso um funcionário esteja focado em outro problema enquanto realiza suas funções, um erro de execução pequeno pode tomar dimensões maiores, por não ser capaz de percebê-lo a tempo. Isto significa que tal PSF funciona como um fator multiplicador neste SIF: a criticidade do erro, bem como sua possibilidade de acontecimento será tão grande quanto subestimado for o nível de atenção do funcionário para com a tarefa.

Os demais PSFs, contudo, tem nível de importância maior para este SIF: problemas existentes em características vitais ao sucesso da tarefa não serão contrabalanceadas apenas pelo funcionário estar exercendo suas funções com atenção. É necessário que os PSFs garantam o sucesso da mesma por estarem sendo bem desempenhados como um todo.

\begin{tabular}{|c|c|c|c|c|}
\hline Demais PSFs & Baixa & Nível de Atenção & Baixa & Baixa \\
\hline Demais PSFs & Baixa & Nível de Atenção & Média & M édia \\
\hline Demais PSFs & Baixa & Nível de Atenção & Alta & M édia \\
\hline Demais PSFs & Média & Nível de Atenção & Baixa & M édia \\
\hline Demais PSFs & Média & Nível de Atenção & Média & M édia \\
\hline Demais PSFs & Média & Nível de Atenção & Alta & Alta \\
\hline Demais PSFs & Alta & Nível de Atenção & $*$ & Alta \\
\hline
\end{tabular}




\section{4. \\ Estudos de Caso}

\section{1.}

\section{Contextualização de PSFs com Tarefas}

Além da crítica de se avaliarem PSFs isoladamente, supondo que os demais estejam sendo bem desempenhados, outra observação pertinente é que PSFs variam de acordo com o contexto (Hollnagel, 2005) - tanto no ponto de vista do nível de importância para cada tarefa, quanto na maneira como ela é desempenhada.

Para compreender como o nível de importância varia, basta considerar uma tarefa com alta demanda física. Ela exigirá de seu executor boas qualidades relativas ao Grupo de PSFs Fatores de Stress Fisiológicos, como, por exemplo: Constrição de Movimentos, Dor ou Desconforto, Exercício Físico, e Fadiga. Porém, uma tarefa de escritório que seja realizada diante de um computador não irá demandar tais PSFs com o mesmo grau de importância (talvez não demande nada deles).

Similarmente, para compreender como um PSF pode ser desempenhado com diferentes graus de qualidade, pode-se considerar uma pessoa que, em uma mesma posição numa empresa, seja responsável por diferentes tarefas. O desempenho de um mesmo PSF pode ser excelente em uma tarefa quanto péssimo em outra, por exemplo: o PSF Disponibilidade de Equipamentos Especiais pode ser satisfatório para uma tarefa em que o número de equipamentos é igual ou superior ao número de funcionários que a executam simultaneamente, e insatisfatório em outra na qual, recorrentemente, o número de equipamentos é inferior ao mínimo necessário para que todos a desempenhem simultaneamente, causando esperas desnecessárias.

Com o objetivo de considerar as diferentes demandas por diferentes PSFs de cada tarefa, o modelo proposto deve ser alimentado com os dados de cada empregado, para cada tarefa, de maneira que se possa calcular a possibilidade de erro de Informação, de Decisão e de Ação para cada uma delas. 


\section{2. \\ O Projeto ConfHIA}

De 2011 a 2012 foi realizado, no DEE-PUC-Rio, um projeto de Pesquisa \& Desenvolvimento intitulado ConfHIA. Esse projeto caracterizou a confiabilidade humana da State Grid, uma empresa chinesa que atua como transmissora de energia do setor elétrico brasileiro. Como a pesquisa e o desenvolvimento, bem como sua implementação, se deram antes da realização da metodologia aqui proposta, o projeto caracterizou-a apenas em nível de processos. Com o objetivo de aplicar a metodologia proposta em situações reais, as informações coletadas no projeto foram utilizadas como estudo de caso, e são apresentadas neste capítulo.

\section{3. Implementação}

A metodologia desenvolvida neste trabalho foi implementada em C\# utilizando o software Visual Studio 2012. O sistema criado é capaz de assimilar todas as variáveis fuzzy, regras fuzzy, e realizar os cálculos necessários. Embora não conte com uma interface amigável/comercializável, sua implementação foi necessária pois seria extremamente demorado, e passível de erros, realizar tais cálculos sem o seu auxílio.

O sistema recebe o desempenho da pessoa a ser avaliada, em relação aos PSFs pertinentes para uma tarefa por vez (com valores de $0 \%$ a $100 \%$ ), e então verifica quais regras são ativadas e, em seguida, determina os conseqüentes com os respectivos graus de pertinência.

Como dito anteriormente, os conjuntos de saída de um SIF são idênticos aos de entrada do SIF seguinte: condição necessária para que se possa calcular como uma possibilidade de erro parcial influencia em outra.

A saída de um SIF, que servirá como variável de entrada para o SIF do nível seguinte, não pode ser defuzzificada, pois isto implicaria em um erro acumulado expressivo, uma vez que o sistema engloba nove níveis de SIFs hierárquicos. Este erro ocorreria porque, ao se defuzzificar um conjunto de saída com um grau de pertinência específico, o resultado é um número que, se alimentado como entrada de um SIF,poderá ativar mais de um conjunto e não somente o conjunto de saída original. Para exemplificar, suponha que a saída de um SIF tenha sido Alta com 
grau de pertinência 0,7 . O que o SIF seguinte deveria receber como variável de entrada seria exatamente Alta com grau de pertinência 0,7. Contudo, se o resultado do primeiro SIF for defuzzificado, para então ser fuzzificado na entrada do SIF seguinte, não só o conjunto Alta será ativado com, possivelmente, um grau de pertinência diferente de 0,7 (dependendo das configurações do sistema fuzzy tais como método de defuzzificação e formato dos conjuntos), mas também o Média será (considerando que o Média possui interseção com o Alta no ponto relativo ao grau de pertinência 0,7 deste conjunto). Assim, seria introduzido um erro no cálculo, uma vez que diferentes regras seriam ativadas, e também diferentes conseqüentes.

O sistema reavalia o funcionário para cada tipo de erro desejado (neste trabalho, erros de Informação, Decisão, e Ação), e exibe qual a possibilidade de erro para cada um deles. Todos os valores intermediários (isto é, internos a cada SIF) são armazenados, tornando possível identificar quais SIFs estão indicando maior possibilidade de erro parcial e, em ultima instância, quais PSFs estão mais críticos para determinada tarefa para um dado tipo de erro. Assim, permite ao usuário uma verificação de qual PSF daquela pessoa é "responsável" por um erro humano em potencial naquela tarefa.

\section{4 . Tarefas Avaliadas}

Para alimentar o Sistema de Inferência Fuzzy como um todo (considerando que todos os SIFs hierárquicos são partes internas dele), idealmente dever-se-ia medir os PSFs de cada operador para cada tarefa. A maneira como eles são medidos pode variar para aprimorar sua veracidade e precisão. No desenvolvimento do projeto ConfHIA, tais informações foram coletadas por meio de questionários. Contudo, como citado, os operadores foram submetidos ao preenchimento dos questionários anteriormente ao início do trabalho. Portanto, responderam os questionários a respeito do desempenho de seus PSFs para o processo como um todo, e não contextualizando-os por tarefa.

Apesar de diferentes tarefas demandarem diferentes PSFs com níveis de importância variável, este trabalho considerou apenas se o PSF era ou não importante para a tarefa em questão. Assim, as tarefas dos procedimentos da State 
Grid foram avaliadas uma a uma, com o objetivo de se estabelecer uma lista para cada uma delas, associando-as aos seus PSFs pertinentes.

Um conjunto seqüencial de tarefas é chamado de procedimento, e os procedimentos tratados neste estudo são listados a seguir:

- Procedimento para Execução de Intervenção (23 tarefas)

- Procedimento para Implantação de Documentação (5 tarefas)

- Procedimento para Operação em Regime Normal (8 tarefas)

- Procedimento para Programação de Intervenção em Urgência ou Emergência (10 tarefas)

- Procedimento para Recomposição (10 tarefas)

- Procedimento para Registros de Operação (9 tarefas)

As associações de cada tarefa de cada procedimento com os PSFs são exibidas no Apêndice A.

\section{5. Casos Hipotéticos (para Validação do Modelo)}

Antes de aplicar a metodologia desenvolvida a um caso real, optou-se por validá-la utilizando situações hipotéticas. Os três primeiros exemplos são:

- uma tarefa que demande todos os PSFs, e um funcionário que esteja com desempenho mínimo em todos eles

- uma tarefa que demande todos os PSFs, e um funcionário que esteja com desempenho máximo em todos eles

- uma tarefa que demande todos os PSFs, e um funcionário que esteja com desempenho médio em todos eles

Para o primeiro caso, o SIF final retornou a possibilidade de erro de 81,70\% para todas as três etapas (Informação, Decisão, e Ação). Isto ocorre por que o método de defuzzificação utilizado é o Centro de Gravidade, e os conjuntos são triangulares. Portanto, por maior que seja o grau de ativação do conjunto de saída "Alto", a saída numérica defuzzificada não poderá ser 100\%. Analogamente, caso os PSFs tenham o melhor desempenho possível, e a saída "Baixa" seja ativada 
com alto grau de pertinência, o sistema não informará $0 \%$ de possibilidade de erro devido ao método de defuzzificação utilizado.

Para o segundo caso, o SIF final retornou a possibilidade de erro de 18,30\%, também para todas as três etapas, valor mais baixo possível de ser produzido para este sistema.

Para o terceiro caso, o SIF final retornou 50,00\% como possibilidade de erro para todas as três diferentes etapas consideradas neste trabalho.

Os resultados obtidos nesta validação foram os esperados: se o funcionário estiver com desempenho máximo em todos os PSFs espera-se que a possibilidade de erro seja a menor possível para todas as etapas. Da mesma forma que se o seu desempenho for o mínimo, espera-se que a possibilidade de erro seja a maior possível.

O próximo exemplo trata de um operador da State Grid (Holding do Brasil), que respondeu aos questionários do projeto ConfHIA, em uma tarefa hipotética que demanda todos os PSFs.

Para este operador, as possibilidades de erro informadas pelo sistema foram:

- $80,91 \%$ para a etapa Informação

- $19,08 \%$ para a etapa Decisão

- $50,00 \%$ para a etapa $A c ̧ a \tilde{o}$

Considerando que o seu desempenho foi o apresentado na Tabela 9 (no projeto ConfHIA o operador deveria selecionar em múltipla escolha as opções de desempenho $0 \%, 25 \%, 50 \%, 75 \%$ ou $100 \%)$.

\begin{tabular}{|c|c|c|}
\hline Grupo de PSFs & PSF & $\begin{array}{c}\text { Avaliação } \\
\text { do } \\
\text { operador }\end{array}$ \\
\hline Fatores Cognitivos & Capacidade Analítica & $75 \%$ \\
\hline Fatores Cognitivos & Capacidade de Antecipação & $75 \%$ \\
\hline Fatores Cognitivos & Capacidade de Classificação & $75 \%$ \\
\hline Fatores Cognitivos & Capacidade de Tomada de Decisões & $75 \%$ \\
\hline Fatores Cognitivos & Continuidade de matrizes ou conjuntos & $50 \%$ \\
\hline Fatores Cognitivos & Estruturação do campo perceptivo (topologia) & $75 \%$ \\
\hline Fatores Cognitivos & Identificação com grupos & $100 \%$ \\
\hline Fatores Cognitivos & Inteligência numérica (capacidade de cálculos) & $75 \%$ \\
\hline Fatores Cognitivos & Memória & $50 \%$ \\
\hline Fatores Cognitivos & Nível de Atenção & $75 \%$ \\
\hline Fatores Cognitivos & Percepção de séries & $75 \%$ \\
\hline Fatores Cognitivos & Predisposição para novos conhecimentos & $75 \%$ \\
\hline
\end{tabular}




\begin{tabular}{|c|c|c|}
\hline Fatores de Personalidade & Afago & $25 \%$ \\
\hline Fatores de Personalidade & Afiliação & $100 \%$ \\
\hline Fatores de Personalidade & Agressão & $50 \%$ \\
\hline Fatores de Personalidade & Assistência & $50 \%$ \\
\hline Fatores de Personalidade & Autonomia & $25 \%$ \\
\hline Fatores de Personalidade & Deferência & $50 \%$ \\
\hline Fatores de Personalidade & Denegação & $25 \%$ \\
\hline Fatores de Personalidade & Desempenho & $50 \%$ \\
\hline Fatores de Personalidade & Dominância & $50 \%$ \\
\hline Fatores de Personalidade & Exibição & $25 \%$ \\
\hline Fatores de Personalidade & Intracepção & $25 \%$ \\
\hline Fatores de Personalidade & Mudança & $50 \%$ \\
\hline Fatores de Personalidade & Ordem & $75 \%$ \\
\hline Fatores de Personalidade & Persistência & $75 \%$ \\
\hline Fatores de Stress Fisiológicos & Constrição de Movimentos & $25 \%$ \\
\hline Fatores de Stress Fisiológicos & Dor ou Desconforto & $50 \%$ \\
\hline Fatores de Stress Fisiológicos & Exercício Físico & $50 \%$ \\
\hline Fatores de Stress Fisiológicos & Fadiga & $50 \%$ \\
\hline Fatores de Stress Fisiológicos & Fome ou Sede & $25 \%$ \\
\hline Fatores de Stress Fisiológicos & Interrupção do Ritmo Circadiano & $50 \%$ \\
\hline Fatores de Stress Fisiológicos & Longa Duração do Stress & $50 \%$ \\
\hline Fatores de Stress Fisiológicos & Repetição de Movimentos & $50 \%$ \\
\hline Fatores de Stress Fisiológicos & Trabalho em Alturas & $0 \%$ \\
\hline Fatores de Stress Psicológicos & Alta Velocidade na Execução da Tarefa & $50 \%$ \\
\hline Fatores de Stress Psicológicos & Ameaças (de Falha, de Perda do Emprego, etc.) & $25 \%$ \\
\hline Fatores de Stress Psicológicos & Carga Pesada de Informações & $50 \%$ \\
\hline Fatores de Stress Psicológicos & Distrações (devido a Ruído, Clarão, Movimentos, etc.) & $50 \%$ \\
\hline Fatores de Stress Psicológicos & Falta de Recompensas, Reconhecimento e Benefícios & $50 \%$ \\
\hline Fatores de Stress Psicológicos & Início Inesperado do Stress & $50 \%$ \\
\hline Fatores de Stress Psicológicos & Motivos Conflitantes sobre o Desempenho no Trabalho & $25 \%$ \\
\hline Fatores de Stress Psicológicos & Perda de Sensibilidade & $25 \%$ \\
\hline Fatores de Stress Psicológicos & Períodos de Vigilância Longos, sem Acontecimentos & $50 \%$ \\
\hline Fatores de Stress Psicológicos & Reforço Negativo & $25 \%$ \\
\hline Fatores de Stress Psicológicos & Sugestões Inconsistentes & $0 \%$ \\
\hline Fatores de Stress Psicológicos & Trabalho Monótono, Degradante ou Sem Sentido & $25 \%$ \\
\hline Fatores Externos & $\begin{array}{c}\text { Ações desenvolvidas por Supervisores, Colegas, } \\
\text { Representantes de Sindicatos, e Pessoal de } \\
\text { Regulamentação }\end{array}$ & $50 \%$ \\
\hline Fatores Externos & Capacidade Crítica da Tarefa & $50 \%$ \\
\hline Fatores Externos & Complexidade da Tarefa (Carga de Informações) & $50 \%$ \\
\hline Fatores Externos & Comunicação & $75 \%$ \\
\hline Fatores Externos & Comunicações Escritas ou Orais & $50 \%$ \\
\hline Fatores Externos & Cuidados e Advertências & $100 \%$ \\
\hline Fatores Externos & Disponibilidade de Equipamentos Especiais & $50 \%$ \\
\hline Fatores Externos & Estrutura de Equipe & $75 \%$ \\
\hline Fatores Externos & Estrutura Organizacional & $50 \%$ \\
\hline Fatores Externos & Fatores de Interface de Hardware & $50 \%$ \\
\hline
\end{tabular}




\begin{tabular}{|c|c|c|}
\hline Fatores Externos & Feedback (Conhecimento de Resultados) & $50 \%$ \\
\hline Fatores Externos & Freqüência e Repetitividade da Tarefa & $50 \%$ \\
\hline Fatores Externos & Horas de Trabalho / Intervalos de Trabalho & $50 \%$ \\
\hline Fatores Externos & Instrumentos & $50 \%$ \\
\hline Fatores Externos & Insumos & $50 \%$ \\
\hline Fatores Externos & Métodos de Trabalho & $50 \%$ \\
\hline Fatores Externos & Políticas da Planta & $50 \%$ \\
\hline Fatores Externos & Procedimentos (Escritos ou Não Escritos) & $75 \%$ \\
\hline Fatores Externos & Qualidade do Ambiente & $50 \%$ \\
\hline Fatores Externos & Quantidade de Pessoal & $50 \%$ \\
\hline Fatores Externos & Rodízio de Turnos & $50 \%$ \\
\hline Fatores Internos & Condição Física/Saúde & $75 \%$ \\
\hline Fatores Internos & Conhecimento de Padrões de Desempenho & $75 \%$ \\
\hline Fatores Internos & Experiência & $100 \%$ \\
\hline Fatores Internos & Influência de outros agentes externos (pessoas, família) & $50 \%$ \\
\hline Fatores Internos & Motivação & $50 \%$ \\
\hline Fatores Internos & Nível de cultura de segurança & $75 \%$ \\
\hline Fatores Internos & Nível de cultura organizacional & $75 \%$ \\
\hline Fatores Internos & Nível de práticas & $75 \%$ \\
\hline Fatores Internos & Qualidade do Treinamento & $75 \%$ \\
\hline Fatores Internos & Tensão Mental ou Física & $50 \%$ \\
\hline \multirow{\delta}{0}{}
\end{tabular}

Tabela 9: Desempenho dos PSFs do operador

\section{6. \\ Casos com Tarefas Reais}

Caso o mesmo operador do exemplo hipotético do sub-item anterior fosse submetido à tarefa "Revisar/Analisar os documentos recebidos com antecedência" do Procedimento para Execução de Intervenção, suas possibilidades de falha seriam:

- $50,00 \%$ para a etapa Informação

- $19,08 \%$ para a etapa Decisão

- $50,00 \%$ para a etapa $A c ̧ a ̃ o$

A tarefa em questão demanda apenas 33 dos 77 PSFs existentes (vide Apêndice A). Porém, apesar da redução de mais da metade do número de PSFs avaliados, apenas a etapa Informação teve sua possibilidade de erro afetada, que foi reduzida de $80,91 \%$ para $50,00 \%$. Isto ocorreu pois a retirada dos PSFs não pertinentes a esta tarefa não influenciam em muito as demais etapas; o comportamento dos PSFs remanescentes permaneceu o mesmo. 
Outro operador foi selecionado no banco de dados do projeto ConfHIA e seu desempenho quanto aos PSFs aqui estudados foram inseridos no SIF desenvolvido neste trabalho. Suas possibilidades de erro para as cinco primeiras tarefas de cada procedimento são exibidas nas Tabelas 10, 11, 12, 13, 14 e 15 .

É importante ressaltar que este operador, assim como todos os demais que responderam aos questionários, apresenta um desempenho muito baixo em alguns PSFs, fazendo com que sua possibilidade de erro seja a máxima possível quando tais PSFs forem pertinentes à tarefa avaliada. Em contrapartida, em alguns outros PSFs o seu desempenho é muito bom, fazendo com que, caso apenas estes sejam pertinentes, a sua possibilidade de erro na tarefa seja a menor possível.

\begin{tabular}{|l|c|c|c|}
\hline \multicolumn{1}{|c|}{ Tarefas } & Informação & Decisão & Ação \\
\hline $\begin{array}{l}\text { Revisar/Analisar os documentos } \\
\text { recebidos com antecedência }\end{array}$ & $81.70 \%$ & $18.30 \%$ & $18.30 \%$ \\
\hline $\begin{array}{l}\text { Esclarecer com a Gerência de } \\
\text { Engenharia de O\&M as eventuais } \\
\text { dúvidas referente aos documentos } \\
\text { recebidos }\end{array}$ & $81.70 \%$ & $18.30 \%$ & $81.70 \%$ \\
\hline $\begin{array}{l}\text { Realizar contatos prévios necessários } \\
\text { para possibilitar a realização dos } \\
\text { contatos com o Centro de Operação do } \\
\begin{array}{l}\text { ONS correspondente, conforme } \\
\text { instrução de operação do ONS, IO- } \\
\text { PD.BR.01 }\end{array}\end{array}$ & $81.70 \%$ & $50.00 \%$ & $50.00 \%$ \\
\hline $\begin{array}{l}\text { Solicitar autorização para inicio da } \\
\text { intervenção ao Centro de Operação do } \\
\text { ONS correspondente }\end{array}$ & $50.00 \%$ & $18.30 \%$ & $18.30 \%$ \\
\hline $\begin{array}{l}\text { Coordenar com outros agentes a } \\
\text { abertura dos documentos AI, ATEIE, } \\
\text { AISTE e/ou Mensagem de Operação, } \\
\text { quando necessário }\end{array}$ & $81.70 \%$ & $18.30 \%$ & $50.00 \%$ \\
\hline
\end{tabular}

Tabela 10: Possibilidades de Erro do operador selecionado para as primeiras tarefas do Procedimento para Execução de Intervenção 


\begin{tabular}{|l|c|c|c|}
\hline \multicolumn{1}{|c|}{ Tarefas } & Informação & Decisão & Ação \\
\hline $\begin{array}{l}\text { Salvar documentos atualizados em } \\
\text { meio digital }\end{array}$ & $18.30 \%$ & $18.30 \%$ & $18.30 \%$ \\
\hline Imprimir documentos atualizados & $18.30 \%$ & $18.30 \%$ & $18.30 \%$ \\
\hline $\begin{array}{l}\text { Arquivar documentos atualizados em } \\
\text { papel }\end{array}$ & $18.30 \%$ & $18.30 \%$ & $18.30 \%$ \\
\hline $\begin{array}{l}\text { Excluir documentos desatualizados, } \\
\text { digital e papel }\end{array}$ & $18.30 \%$ & $18.30 \%$ & $18.30 \%$ \\
\hline $\begin{array}{l}\text { Estudar alteração dos documentos } \\
\text { atualizados, se necessário }\end{array}$ & $18.30 \%$ & $18.30 \%$ & $18.30 \%$ \\
\hline
\end{tabular}

Tabela 11: Possibilidades de Erro do operador selecionado para as tarefas do Procedimento para Implantação de Documentação

O desempenho do operador selecionado está muito bom para as tarefas do Procedimento para Implantação de Documentação (Tabela 11), a possibilidade de erro retornada pelo SIF para todas as tarefas deste procedimento é a menor possível. Assim, após a verificação do resultado do sistema, o gestor seria aconselhado a destinar tal funcionário à execução destas tarefas.

\begin{tabular}{|l|c|c|c|}
\hline \multicolumn{1}{|c|}{ Tarefas } & Informação & Decisão & Ação \\
\hline Preencher o Livro de Ocorrências & $81.70 \%$ & $18.30 \%$ & $18.30 \%$ \\
\hline $\begin{array}{l}\text { Elaborar Relatório Diário de Operação } \\
\text { - RDO }\end{array}$ & $81.70 \%$ & $18.30 \%$ & $18.30 \%$ \\
\hline $\begin{array}{l}\text { Revisar Relatório Diário de Operação } \\
\text { - RDO }\end{array}$ & $81.70 \%$ & $18.30 \%$ & $18.30 \%$ \\
\hline $\begin{array}{l}\text { Enviar Relatório Diário de Operação - } \\
\text { RDO }\end{array}$ & $81.70 \%$ & $18.30 \%$ & $50.00 \%$ \\
\hline Criar Eventos & $81.70 \%$ & $18.30 \%$ & $18.30 \%$ \\
\hline
\end{tabular}

Tabela 12: Possibilidades de Erro do operador selecionado para as cinco primeiras tarefas do Procedimento para Registros de Operação 


\begin{tabular}{|l|c|c|c|}
\hline \multicolumn{1}{|c|}{ Tarefas } & Informação & Decisão & Ação \\
\hline $\begin{array}{l}\text { Supervisionar as instalações de sua } \\
\text { responsabilidade }\end{array}$ & $81.70 \%$ & $18.30 \%$ & $18.30 \%$ \\
\hline $\begin{array}{l}\text { Efetuar testes de funcionamento nos } \\
\text { equipamentos de comunicação }\end{array}$ & $81.70 \%$ & $18.30 \%$ & $18.30 \%$ \\
\hline $\begin{array}{l}\text { Executar manobras nos equipamentos } \\
\text { das subestações de sua } \\
\text { responsabilidade sempre que } \\
\text { necessário (controle de tensão) }\end{array}$ & $81.70 \%$ & $18.30 \%$ & $18.30 \%$ \\
\hline $\begin{array}{l}\text { Delegar ao operador - mantenedor de } \\
\text { uma subestação remota de sua } \\
\text { responsabilidade a execução de } \\
\text { manobras sempre que necessário }\end{array}$ & $18.30 \%$ & $18.30 \%$ & $18.30 \%$ \\
\hline Detectar as anormalidades & $18.30 \%$ & $18.30 \%$ & $18.30 \%$ \\
\hline
\end{tabular}

Tabela 13: Possibilidades de Erro do operador selecionado para as cinco primeiras tarefas do Procedimento para Operação em Regime Normal

\begin{tabular}{|l|c|c|c|}
\hline \multicolumn{1}{|c|}{ Tarefas } & Informação & Decisão & Ação \\
\hline Receber Solicitação de Intervenção & $18.30 \%$ & $18.30 \%$ & $18.30 \%$ \\
\hline $\begin{array}{l}\text { Cadastrar intervenção no aplicativo } \\
\text { SGI do ONS }\end{array}$ & $50.00 \%$ & $18.30 \%$ & $18.30 \%$ \\
\hline $\begin{array}{l}\text { Realizar contato com o Centro de } \\
\text { Operação do ONS correspondente } \\
\text { para obter aprovação da intervenção } \\
\text { cadastrada }\end{array}$ & $50.00 \%$ & $18.30 \%$ & $18.30 \%$ \\
\hline $\begin{array}{l}\text { Coordenar a intervenção com os } \\
\text { demais agentes envolvidos quando } \\
\text { necessário }\end{array}$ & $81.70 \%$ & $18.30 \%$ & $18.30 \%$ \\
\hline $\begin{array}{l}\text { Informar ao solicitante a aprovação da } \\
\text { intervenção pelo ONS }\end{array}$ & $81.70 \%$ & $18.30 \%$ & $50.00 \%$ \\
\hline
\end{tabular}

Tabela 14: Possibilidades de Erro do operador selecionado para as cinco primeiras tarefas do Procedimento para Programação de Intervenção em Urgência ou Emergência 


\begin{tabular}{|l|c|c|c|}
\hline \multicolumn{1}{|c|}{ Tarefas } & Informação & Decisão & Ação \\
\hline $\begin{array}{l}\text { Identificar a configuração das SE's } \\
\text { envolvidas após a ocorrência, } \\
\text { reconhecendo o estado dos disjuntores } \\
\text { nas telas dos diagramas unifilares } \\
\text { gerais e também de cada SE }\end{array}$ & $81.70 \%$ & $18.30 \%$ & $18.30 \%$ \\
\hline $\begin{array}{l}\text { Identificar na Lista de Alarmes as } \\
\text { proteções atuadas }\end{array}$ & $81.70 \%$ & $50.00 \%$ & $50.00 \%$ \\
\hline $\begin{array}{l}\text { Verificar a presença de bloqueios em } \\
\text { disjuntores }\end{array}$ & $81.70 \%$ & $18.30 \%$ & $18.30 \%$ \\
\hline $\begin{array}{l}\text { Verificar a existência de documento } \\
\text { de intervenção aberto que exija } \\
\text { contato com a equipe de campo para } \\
\text { recomposição da função transmissão } \\
\text { ou disjuntor que sofreu o } \\
\text { desligamento }\end{array}$ & $50.00 \%$ & $18.30 \%$ & $18.30 \%$ \\
\hline $\begin{array}{l}\text { Disponibilizar para operação a função } \\
\text { transmissão ou disjuntor que sofreu o } \\
\text { desligamento ao Centro de Operação } \\
\text { do ONS correspondente }\end{array}$ & $81.70 \%$ & $18.30 \%$ & $18.30 \%$ \\
\hline
\end{tabular}

Tabela 15: Possibilidades de Erro do operador selecionado para as cinco primeiras tarefas do Procedimento para Recomposição

Após a verificação dos resultados obtidos, percebe-se que, para este operador, o sistema retornou apenas três valores de saída distintos. Isto ocorre pois o funcionário teve seus PSFs avaliados para o processo como um todo, e não por tarefa, como deveria ter sido. Assim, a única variação possível é a causada pela presença ou não, em cada tarefa, dos PSFs críticos.

A comparação destes resultados com os do projeto ConfHIA é uma confirmação de que o desempenho do operador foi aquém do esperado para a maioria dos PSFs, uma vez que o seu Grau de Atendimento Global para o processo como um todo foi de 56,77\%. Este conceito de Grau de Atendimento Global representa o desempenho de um operador em relação a todas as tarefas em conjunto, isto é, a qualidade geral do seu desempenho (vale destacar que isso é uma medida válida apenas para a ocasião da avaliação, podendo variar significativamente caso ele seja realocado. Uma nova avaliação, em um novo projeto, também poderá apresentar um resultado distinto). 


\section{5. \\ Conclusões e Trabalhos Futuros}

\section{1.}

\section{Conclusões}

Este trabalho demonstrou como pode ser realizada a modelagem de um Sistema de Inferência Fuzzy, composto de sub-sistemas hierárquicos, para a caracterização da confiabilidade humana. Este sistema foi desenvolvido para ser aplicado em qualquer tarefa que tenha seus PSFs (Performance Shaping Factors) previamente selecionados e medidos. Sua precisão é diretamente proporcional ao cuidado que se tem ao medir tais PSFs, e permite indicar quais são as possibilidades de erro humano nas etapas de recebimento de informação, de tomada de decisão e de execução real de cada tarefa.

O sistema desenvolvido apresentou bom desempenho ao avaliar as possibilidades de erros de tarefas hipotéticas e reais. Além disso, demonstrou a vantagem de contextualizar os PSFs, tornando mais realista a caracterização da confiabilidade humana.

Como esperado, as situações que tratam de PSFs relativos à comunicação indicaram maior erro de informação; os PSFs de fatores cognitivos demonstraram ter maior impacto na etapa de tomada de decisão, enquanto que os fisiológicos afetaram a execução diretamente.

A metodologia aqui proposta, se aplicada em empresas e indústrias, permitirá a gestores contarem com uma ferramenta para lhes auxiliar em:

- tomar decisão de quais tarefas devem receber mais atenção por estarem mais críticas

- identificar os operadores mais aptos a realizarem determinadas tarefas - possibilitando que as responsabilidades de cada funcionário sejam re-organizadas

- identificar as características mais críticas de cada operador, que poderão culminar em erros 
Com as informações disponibilizadas por esta metodologia espera-se que erros em potencial sejam identificados antes que de fato ocorram.

\section{2.}

\section{Trabalhos Futuros}

A aplicação do modelo proposto pressupõe a instalação de um software na empresa. Deve-se confeccionar um programa que embarque a metodologia aqui desenvolvida, e adicione a ela características comerciais, tais como: interface amigável, tratamento de acesso, cadastro de funcionários, opções de edição de tarefas já cadastradas, inclusão de tarefas e procedimentos novos, etc. Enquanto a parte matemática foi totalmente implementada, cabe lembrar que questões relativas a consultoria também devem ser executadas em uma possível comercialização da ferramenta (avaliação dos PSFs pertinentes às tarefas da empresa).

As seguintes oportunidades de trabalhos futuros podem ser destacadas:

- As variáveis fuzzy utilizadas neste trabalho foram tratadas com três valores linguísticos: Baixo, Médio e Alto. Eventualmente, uma melhor avaliação poderá ser obtida com a utilização de cinco valores: Muito Baixo, Baixo, Médio, Alto, e Muito Alto.

- Redimensionamento dos conjuntos fuzzy por variável: cabe testar outros formatos que não apenas o triangular empregado neste trabalho.

- O método de defuzzificação utilizado foi o Centro de Gravidade, porém outros métodos poderiam ser testados para se tentar atingir os valores $0 \%$ e $100 \%$ como resultados mínimo e máximo, respectivamente.

- Segundo Hendrickson (2010), cada etapa que compõe uma tarefa contém subetapas, isto é, a etapa de Informação contém as sub-etapas Informação, Decisão e Ação, assim como a etapa de Decisão contém as sub-etapas Informação, Decisão, e Ação, e a etapa de Ação também contém suas subetapas Informação, Decisão, e Ação. A metodologia aqui desenvolvida se 
ateve a avaliar os erros humanos apenas nas três etapas de alto nível, sem considerar as sub-etapas. Um trabalho futuro poderia considerá-las.

- Aplicar a metodologia em uma empresa em que os operadores tenham seus PSFs medidos por tarefa, de forma que o sistema seja idealmente alimentado.

- A mesma metodologia pode ser aplicada a outras áreas do conhecimento, se variáveis representativas puderem substituir os PSFs. A confiabilidade humana é constituída de PSFs como suas variáveis básicas, ou de baixo nível, assim como a sustentabilidade, por exemplo, pode ser avaliada como constituída de indicadores de relatórios. É possível, portanto, que a sustentabilidade de uma empresa seja avaliada de maneira análoga à confiabilidade humana na metodologia aqui apresentada. 


\section{Referências Bibliográficas}

SWAIN, A. D. Human Reliability Analysis: need, status, trends and limitations. Reliability Engineering and System Safety, v. 29, n. 3, pp. 301-313, 1990.

LORENZO, D. K. API-770 Reducing Human Errors (A Manager's Guide to Reducing Human Errors - Improving Human Performance in the Process Industries). American Petroleum Institute Inc., 2001.

Federal Aviation Administration. System Safety Handbook. U.S. Department of Transportation. 2013.

JINZHU, X. FPSO Design to Minimise Operational Downtime due to Adverse Metocean Conditions off North West Australia. Australia, 2012.

SHAPPELL, S. A.; WIEGMANN, D. A. Applying reason: The human factors analysis and classification system (HFACS). Human Factors and Aerospace Safety, Vol 1(1), pp. 59-86, 2001.

JALLON, R.; IMBEAU, D.; de MARCELLIS-WARIN, N. Development of an indirect-cost calculation model suitable for workplace use. Journal of Safety Research, Volume 42, Issue 3, pp. 149-164, 2011.

SZWARCMAN, D.M.; DOMECH, J.; TANSCHEIT, R.; VELLASCO, M.; PACHECO, M.; RIBEIRO N. P. A Fuzzy System for the Assessment of Human Reliability. Joint 2009 International Fuzzy Systems Association World Congress and 2009 European Society of Fuzzy Logic and Technology Conference, Lisbon, Portugal, pp. 1102-1107, 2009.

DOMECH, J.; TANSCHEIT, R.; VELLASCO, M.; PACHECO, M.; SZWARCMAN, D.M. A Fuzzy Approach to the Study of Human Reliability in the Petroleum Industry. Advances in Soft Computing - Theoretical Advances and Applications of Fuzzy Logic and Soft Computing, Springer, 42: pp. 415-424, 2007.

HOLlNAGEL, E. Human Reliability Assessment In Context, Linköping, Suécia, 2005.

DOMECH, J. M. A Fuzzy Approach to Evaluation the Human Reliability In the Ultrasonic Nondestructive Examinations, Ph.D. Thesis, COPPE/UFRJ, Brasil, 2004.

BADDELEY, A. Working memory: looking back and looking forward. Nature Reviews Neuroscience 4 (10): pp. 829-839, 2003. 
HENDRICKSON, S. M. L.; WHALEY, A. M.; BORING, R. L.; CHANG, J. Y. H.; SHEN, S. H.; MOSLEH, A.; OXSTRAND, J. H.; FORESTER, J. A.; KELLY, D. L. A Mid-Layer Model for Human Reliability Analysis: Understanding the Cognitive Causes of Human Failure Events. Idaho National Laboratory, 2010.

U.S. Department of Labor. Ergonomics: The Study of Work. Occupational Safety and Health Administration, OSHA 3125, Estados Unidos, 2000.

WANG, Y. On Cognitive Properties of Human Factors and Error Models in Engineering and Socialization. University of Calgary, Canada, 2008.

FUJITA, Y. Human Reliability Analysis: A Human Point of View. Reliability Engineering and System Safety, Ed. Elsevier Applied Science, v. 38, 1992.

SWAIN, A. D. Human Reliability Analysis: need, status, trends and limitations. Reliability Engineering and System Safety, v. 29, n. 3, pp. 301-313, 1990.

SWAIN, A. D., GUTTMANN, H. E. Handbook of Human Reliability Analysis with Emphasis on Nuclear Power Plant Applications. NUREG/CR-1278, USNRC, 1983.

RASSMUSSEN, J. Learning from experience? How? Some research issues in industrial risk management. Ed. Octares/Enterprises, Marseille, 1990.

WHALlEY, S. P. The use of Human Reliability in Risk Studies. ABB Impel Ltd., 1983.

EMBREY, D.E. Human Error. Sigtto Information Paper, Nº 8, 1990.

HOLLnAGEL, E. Cognitive Reliability and Error Analysis Method, Elsevier Science, Oxford, England, 1998.

KIM, I. S. Human reliability analysis in the man-machine interface design review. Annals of Nuclear Energy, v. 28, pp. 1069-1081, 2001.

SZWARCMAN, D. M.; DOMECH, J.; TANSCHEIT, R.; VELLASCO, M.; RIBEIRO, N. P. Um Sistema Fuzzy para Caracterização da Confiabilidade Humana. Congresso Brasileiro de Automática, 2010.

Embrey, D.; ZAED, S. A Set Of Computer Based Tools Identifying And Preventing Human Error In Plant Operations. 2010. 


\section{Apêndice A - Tarefas e PSFs Pertinentes}

São mostrados nas Tabelas 16, 17, 18, 19, 20 e 21 os PSFs considerados para cada tarefa. Cada tabela abaixo é referente a um procedimento, essas são apresentadas em quatro colunas: a primeira mostra a ordem da tarefa dentro do procedimento, isto é qual a sua posição seqüencial, a segunda mostra a descrição da tarefa, a terceira indica a qual Grupo de PSFs pertence o PSF de cada linha da tabela, e a última contém os PSFs pertinentes à tarefa em questão.

As associações de cada tarefa de cada procedimento com os PSFs são exibidas abaixo:

\begin{tabular}{|c|c|c|c|}
\hline \multicolumn{4}{|c|}{ Procedimento para Execução de Intervenção } \\
\hline & Tarefas & Grupo de PSFs & PSF \\
\hline \multirow{18}{*}{1} & \multirow{18}{*}{$\begin{array}{l}\text { Revisar/Analisar os } \\
\text { documentos recebidos } \\
\text { com antecedência }\end{array}$} & Fatores Cognitivos & Capacidade Analítica \\
\hline & & Fatores Cognitivos & Capacidade de Antecipação \\
\hline & & Fatores Cognitivos & Capacidade de Classificação \\
\hline & & Fatores Cognitivos & $\begin{array}{l}\text { Capacidade de Tomada de } \\
\text { Decisões }\end{array}$ \\
\hline & & Fatores Cognitivos & Nível de Atenção \\
\hline & & Fatores de Personalidade & Ordem \\
\hline & & Fatores de Personalidade & Agressão \\
\hline & & Fatores de Personalidade & Autonomia \\
\hline & & Fatores de Personalidade & Desempenho \\
\hline & & $\begin{array}{l}\text { Fatores de Stress } \\
\text { Fisiológicos }\end{array}$ & Fome ou Sede \\
\hline & & $\begin{array}{c}\text { Fatores de Stress } \\
\text { Fisiológicos }\end{array}$ & $\begin{array}{c}\text { Interrupção do Ritmo } \\
\text { Circadiano }\end{array}$ \\
\hline & & $\begin{array}{l}\text { Fatores de Stress } \\
\text { Fisiológicos }\end{array}$ & Longa Duração do Stress \\
\hline & & $\begin{array}{l}\text { Fatores de Stress } \\
\text { Psicológicos }\end{array}$ & $\begin{array}{c}\text { Ameaças (de Falha, de Perda } \\
\text { do Emprego, etc.) }\end{array}$ \\
\hline & & $\begin{array}{l}\text { Fatores de Stress } \\
\text { Psicológicos }\end{array}$ & Carga Pesada de Informações \\
\hline & & $\begin{array}{l}\text { Fatores de Stress } \\
\text { Psicológicos }\end{array}$ & $\begin{array}{l}\text { Falta de Recompensas, } \\
\text { Reconhecimento e Benefícios }\end{array}$ \\
\hline & & $\begin{array}{l}\text { Fatores de Stress } \\
\text { Psicológicos }\end{array}$ & Início Inesperado do Stress \\
\hline & & $\begin{array}{l}\text { Fatores de Stress } \\
\text { Psicológicos }\end{array}$ & $\begin{array}{c}\text { Motivos Conflitantes sobre o } \\
\text { Desempenho no Trabalho }\end{array}$ \\
\hline & & Fatores de Stress & Reforço Negativo \\
\hline
\end{tabular}




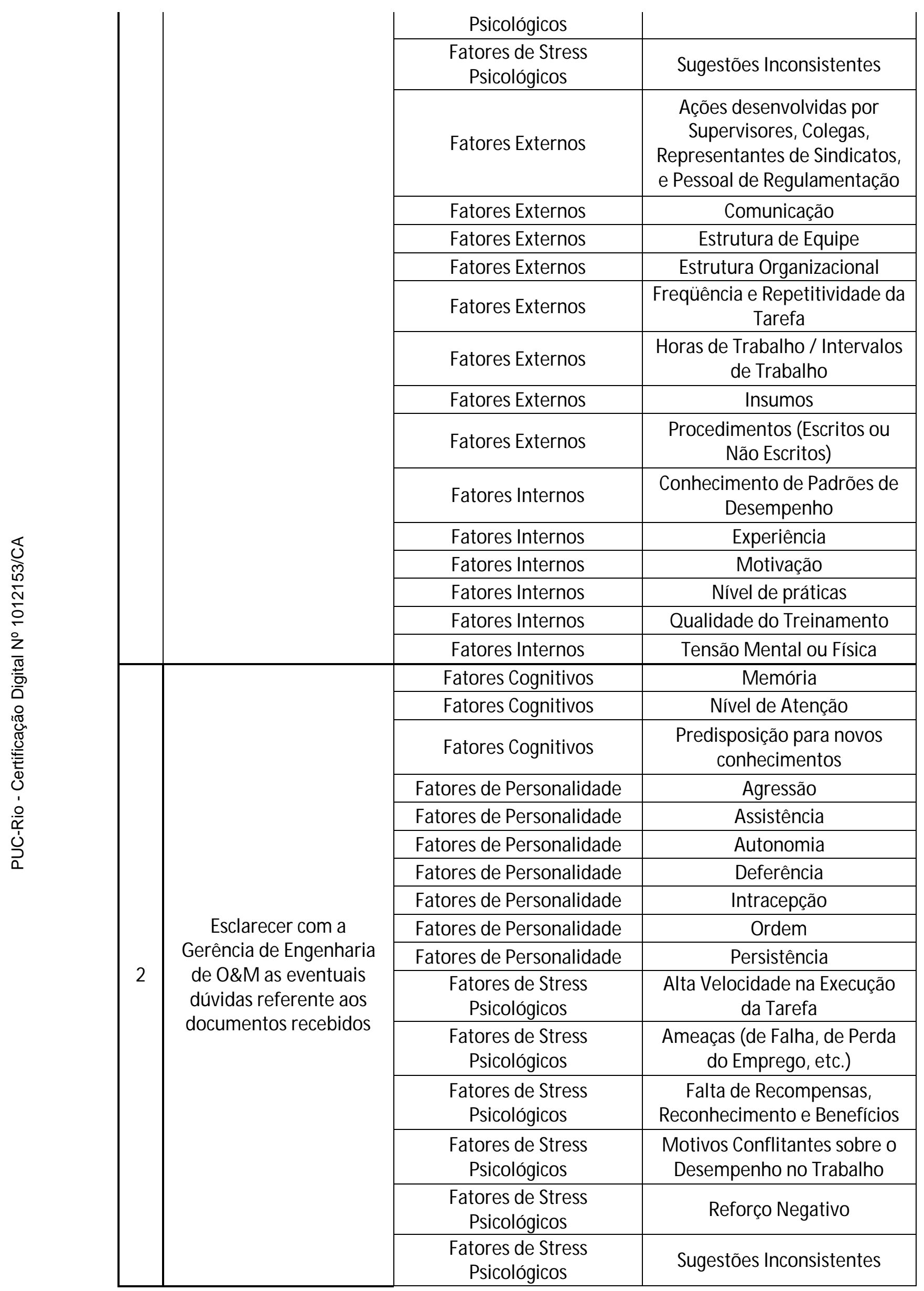




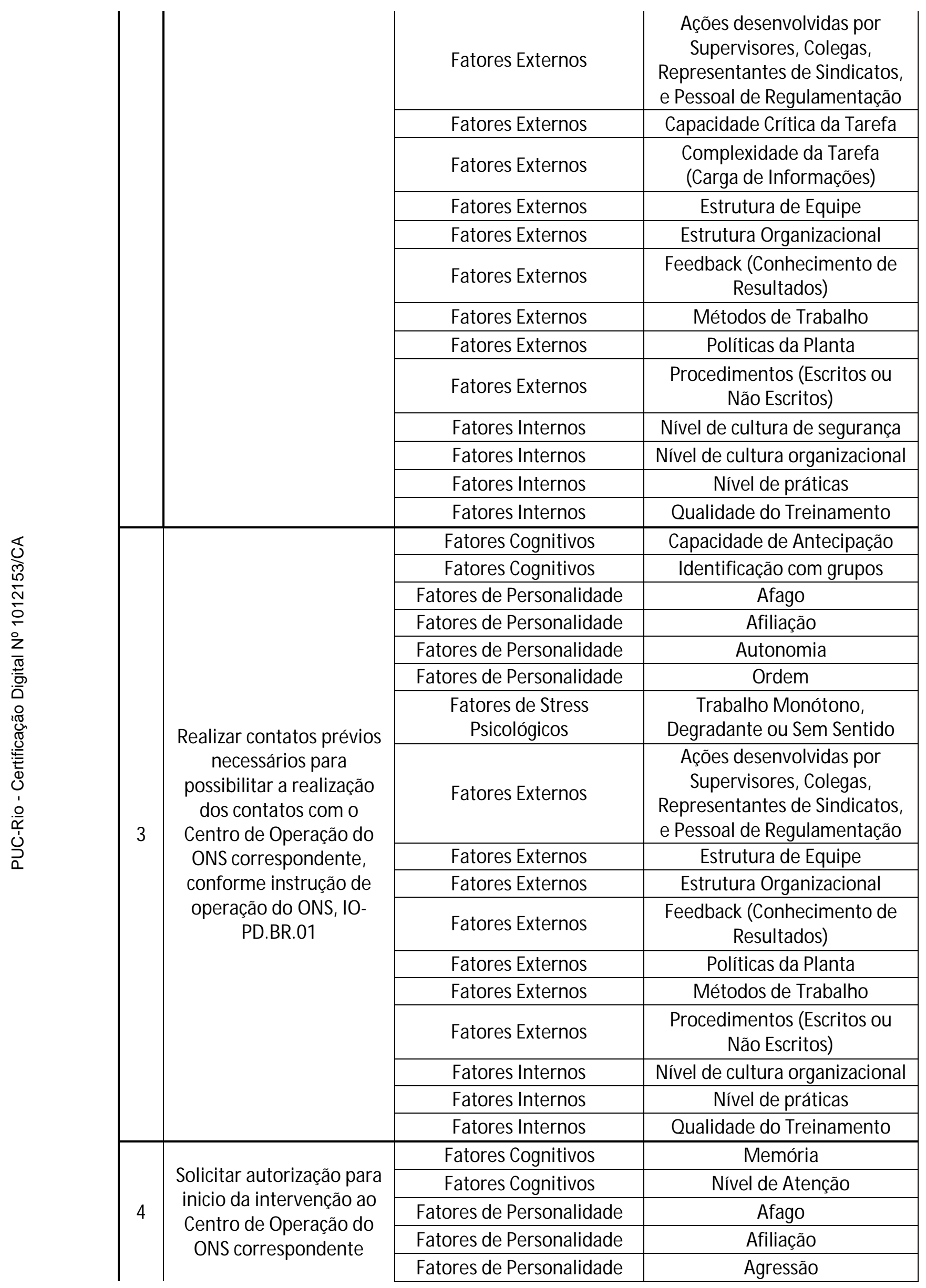




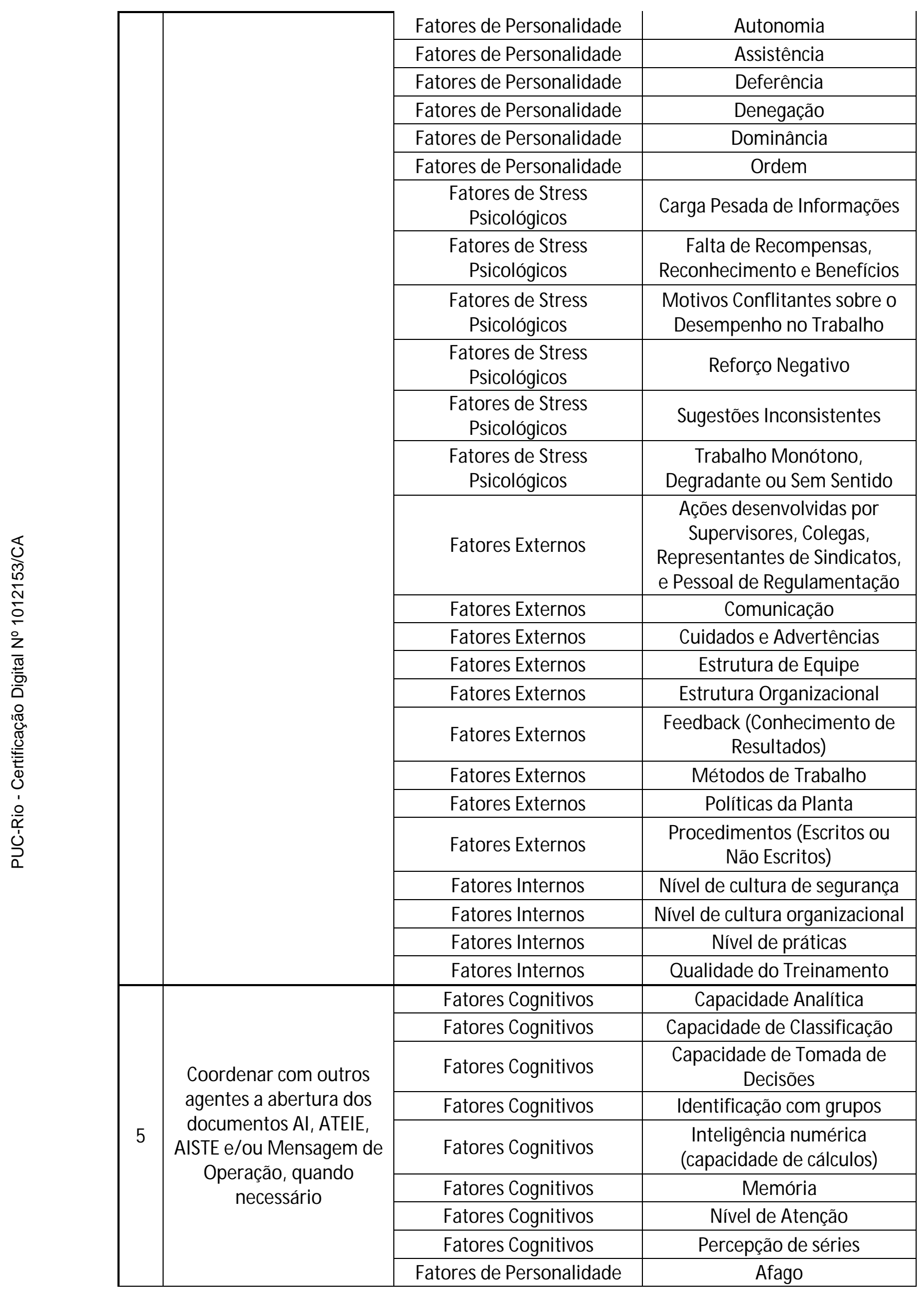




\begin{tabular}{|c|c|c|c|}
\hline & & Fatores de Personalidade & Afiliação \\
\hline & & Fatores de Personalidade & Agressão \\
\hline & & Fatores de Personalidade & Assistência \\
\hline & & Fatores de Personalidade & Autonomia \\
\hline & & Fatores de Personalidade & Desempenho \\
\hline & & Fatores de Personalidade & Dominância \\
\hline & & Fatores de Personalidade & Ordem \\
\hline & & $\begin{array}{l}\text { Fatores de Stress } \\
\text { Psicológicos }\end{array}$ & $\begin{array}{c}\text { Alta Velocidade na Execução } \\
\text { da Tarefa }\end{array}$ \\
\hline & & $\begin{array}{l}\text { Fatores de Stress } \\
\text { Psicológicos }\end{array}$ & Carga Pesada de Informações \\
\hline & & $\begin{array}{l}\text { Fatores de Stress } \\
\text { Psicológicos }\end{array}$ & Início Inesperado do Stress \\
\hline & & $\begin{array}{l}\text { Fatores de Stress } \\
\text { Psicológicos }\end{array}$ & Reforço Negativo \\
\hline & & $\begin{array}{l}\text { Fatores de Stress } \\
\text { Psicológicos }\end{array}$ & Sugestões Inconsistentes \\
\hline & & Fatores Externos & $\begin{array}{c}\text { Ações desenvolvidas por } \\
\text { Supervisores, Colegas, } \\
\text { Representantes de Sindicatos, } \\
\text { e Pessoal de Regulamentação }\end{array}$ \\
\hline ભ్ & & Fatores Externos & Capacidade Crítica da Tarefa \\
\hline $\begin{array}{l}\bar{N} \\
\frac{1}{0} \\
\frac{1}{7}\end{array}$ & & Fatores Externos & $\begin{array}{l}\text { Complexidade da Tarefa } \\
\text { (Carga de Informações) }\end{array}$ \\
\hline$\frac{\pi}{\pi}$ & & Fatores Externos & Comunicação \\
\hline & & Fatores Externos & Estrutura de Equipe \\
\hline 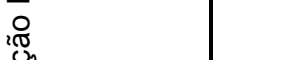 & & Fatores Externos & Estrutura Organizacional \\
\hline 胥 & & Fatores Externos & $\begin{array}{c}\text { Procedimentos (Escritos ou } \\
\text { Não Escritos) }\end{array}$ \\
\hline & & Fatores Externos & Rodízio de Turnos \\
\hline$\stackrel{\circ}{\sim}$ & & Fatores Externos & Quantidade de Pessoal \\
\hline & & Fatores Internos & Experiência \\
\hline & & Fatores Internos & M otivação \\
\hline & & Fatores Internos & Nível de cultura de segurança \\
\hline & & Fatores Internos & Nível de cultura organizacional \\
\hline & & Fatores Internos & Nível de práticas \\
\hline & & Fatores Internos & Qualidade do Treinamento \\
\hline & & Fatores Internos & Tensão Mental ou Física \\
\hline & & Fatores Cognitivos & Capacidade Analítica \\
\hline & Executar as manobras & Fatores Cognitivos & Nível de Atenção \\
\hline & necessárias para liberar & Fatores Cognitivos & Percepção de séries \\
\hline & os equipamentos para & Fatores de Personalidade & Autonomia \\
\hline 6 & manutenção, após & Fatores de Personalidade & Ordem \\
\hline & receber autorização do & Fatores de Personalidade & Persistência \\
\hline & $\begin{array}{l}\text { Centro de Operação do } \\
\text { ONS correspondente }\end{array}$ & $\begin{array}{l}\text { Fatores de Stress } \\
\text { Fisiológicos }\end{array}$ & Constrição de Movimentos \\
\hline & & Fatores de Stress & Dor ou Desconforto \\
\hline
\end{tabular}




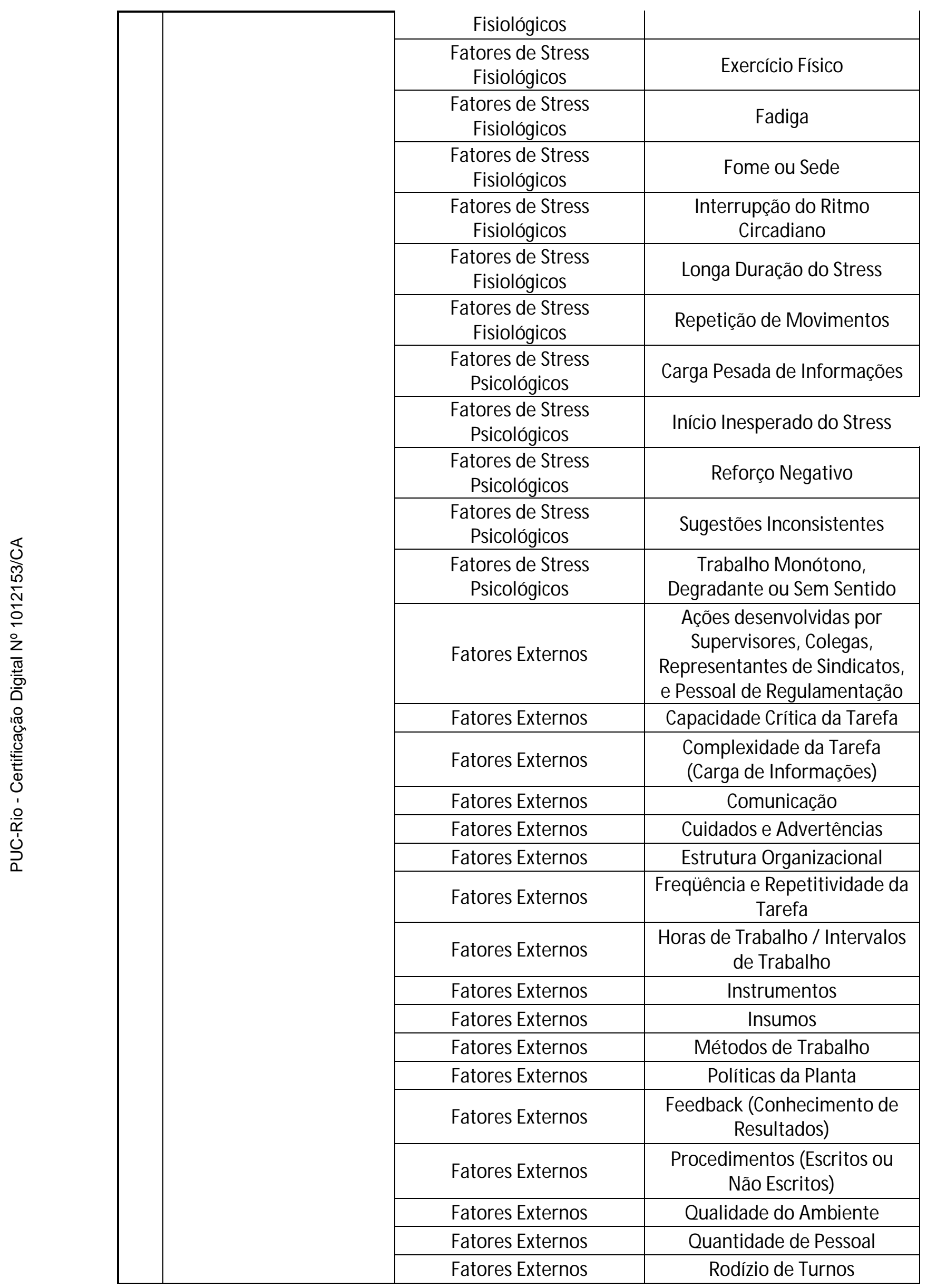




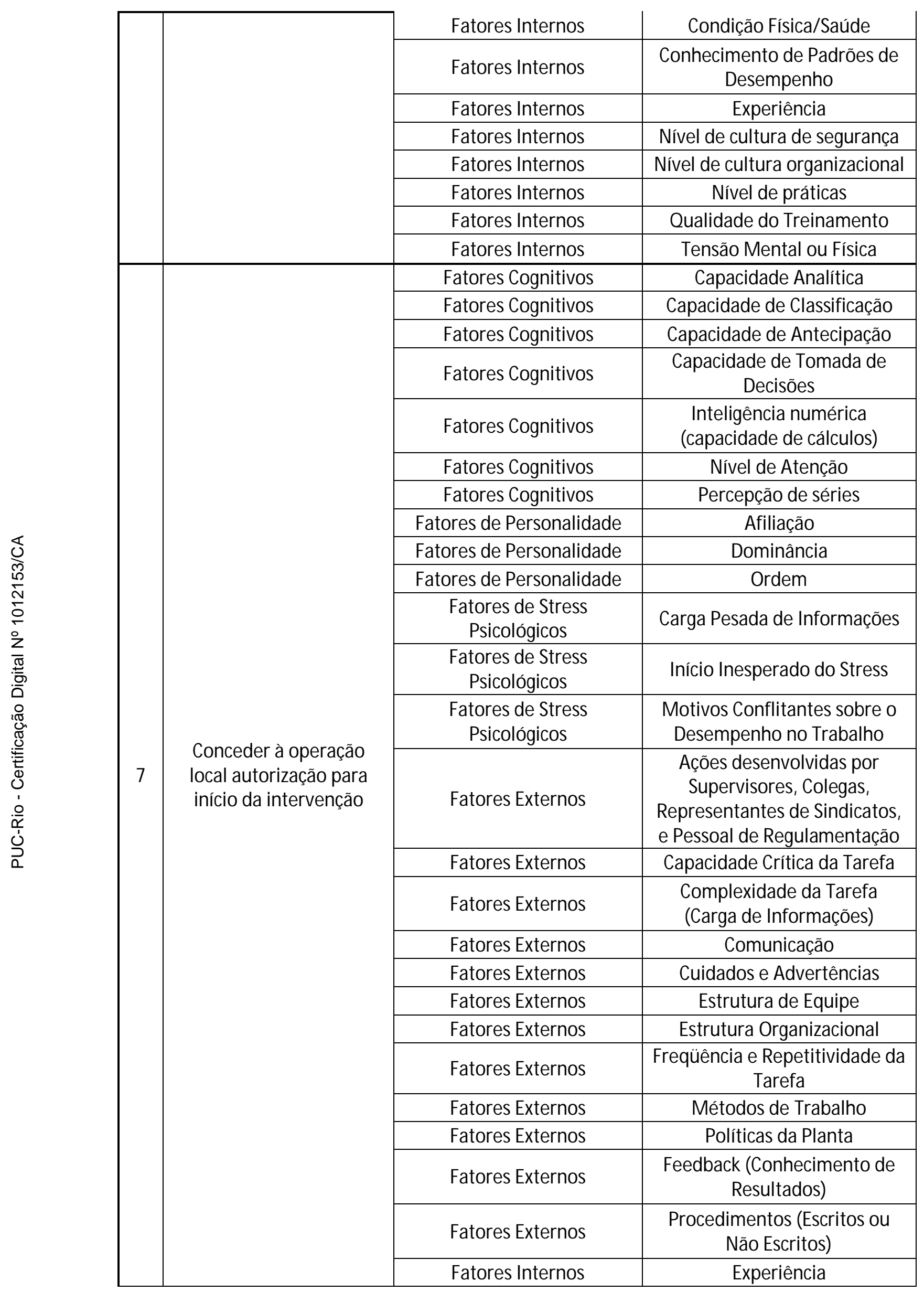




\begin{tabular}{|c|c|c|c|}
\hline & & Fatores Internos & Nível de cultura de segurança \\
\hline & & Fatores Internos & Nível de cultura organizacional \\
\hline & & Fatores Internos & Nível de práticas \\
\hline & & Fatores Internos & Qualidade do Treinamento \\
\hline \multirow{28}{*}{8} & \multirow{28}{*}{$\begin{array}{c}\text { Receber da operação } \\
\text { local as instalações livres } \\
\text { para operação }\end{array}$} & Fatores Cognitivos & Memória \\
\hline & & Fatores Cognitivos & Nível de Atenção \\
\hline & & Fatores Cognitivos & $\begin{array}{l}\text { Predisposição para novos } \\
\text { conhecimentos }\end{array}$ \\
\hline & & Fatores de Personalidade & Afago \\
\hline & & Fatores de Personalidade & Afiliação \\
\hline & & Fatores de Personalidade & Agressão \\
\hline & & Fatores de Personalidade & Autonomia \\
\hline & & Fatores de Personalidade & Deferência \\
\hline & & Fatores de Personalidade & Mudança \\
\hline & & Fatores de Personalidade & Ordem \\
\hline & & $\begin{array}{l}\text { Fatores de Stress } \\
\text { Fisiológicos }\end{array}$ & Fome ou Sede \\
\hline & & $\begin{array}{l}\text { Fatores de Stress } \\
\text { Fisiológicos }\end{array}$ & $\begin{array}{l}\text { Interrupção do Ritmo } \\
\text { Circadiano }\end{array}$ \\
\hline & & $\begin{array}{l}\text { Fatores de Stress } \\
\text { Psicológicos }\end{array}$ & $\begin{array}{c}\text { Alta Velocidade na Execução } \\
\text { da Tarefa }\end{array}$ \\
\hline & & $\begin{array}{l}\text { Fatores de Stress } \\
\text { Psicológicos }\end{array}$ & Carga Pesada de Informações \\
\hline & & $\begin{array}{l}\text { Fatores de Stress } \\
\text { Psicológicos }\end{array}$ & Início Inesperado do Stress \\
\hline & & $\begin{array}{l}\text { Fatores de Stress } \\
\text { Psicológicos }\end{array}$ & Reforço Negativo \\
\hline & & $\begin{array}{l}\text { Fatores de Stress } \\
\text { Psicolóqicos }\end{array}$ & Sugestões Inconsistentes \\
\hline & & Fatores Externos & $\begin{array}{c}\text { Ações desenvolvidas por } \\
\text { Supervisores, Colegas, } \\
\text { Representantes de Sindicatos, } \\
\text { e Pessoal de Regulamentação }\end{array}$ \\
\hline & & Fatores Externos & Capacidade Crítica da Tarefa \\
\hline & & Fatores Externos & $\begin{array}{l}\text { Complexidade da Tarefa } \\
\text { (Carga de Informações) }\end{array}$ \\
\hline & & Fatores Externos & Comunicação \\
\hline & & Fatores Externos & $\begin{array}{l}\text { Freqüência e Repetitividade da } \\
\text { Tarefa }\end{array}$ \\
\hline & & Fatores Externos & M étodos de Trabalho \\
\hline & & Fatores Externos & Políticas da Planta \\
\hline & & Fatores Internos & Nível de cultura de segurança \\
\hline & & Fatores Internos & Nível de cultura organizacional \\
\hline & & Fatores Internos & Nível de práticas \\
\hline & & Fatores Internos & Qualidade do Treinamento \\
\hline \multirow[b]{2}{*}{9} & \multirow{2}{*}{$\begin{array}{l}\text { Coordenar com outros } \\
\text { agentes o fechamento } \\
\text { dos documentos Al, }\end{array}$} & Fatores Cognitivos & Capacidade Analítica \\
\hline & & Fatores Cognitivos & $\begin{array}{c}\text { Capacidade de Tomada de } \\
\text { Decisões }\end{array}$ \\
\hline
\end{tabular}




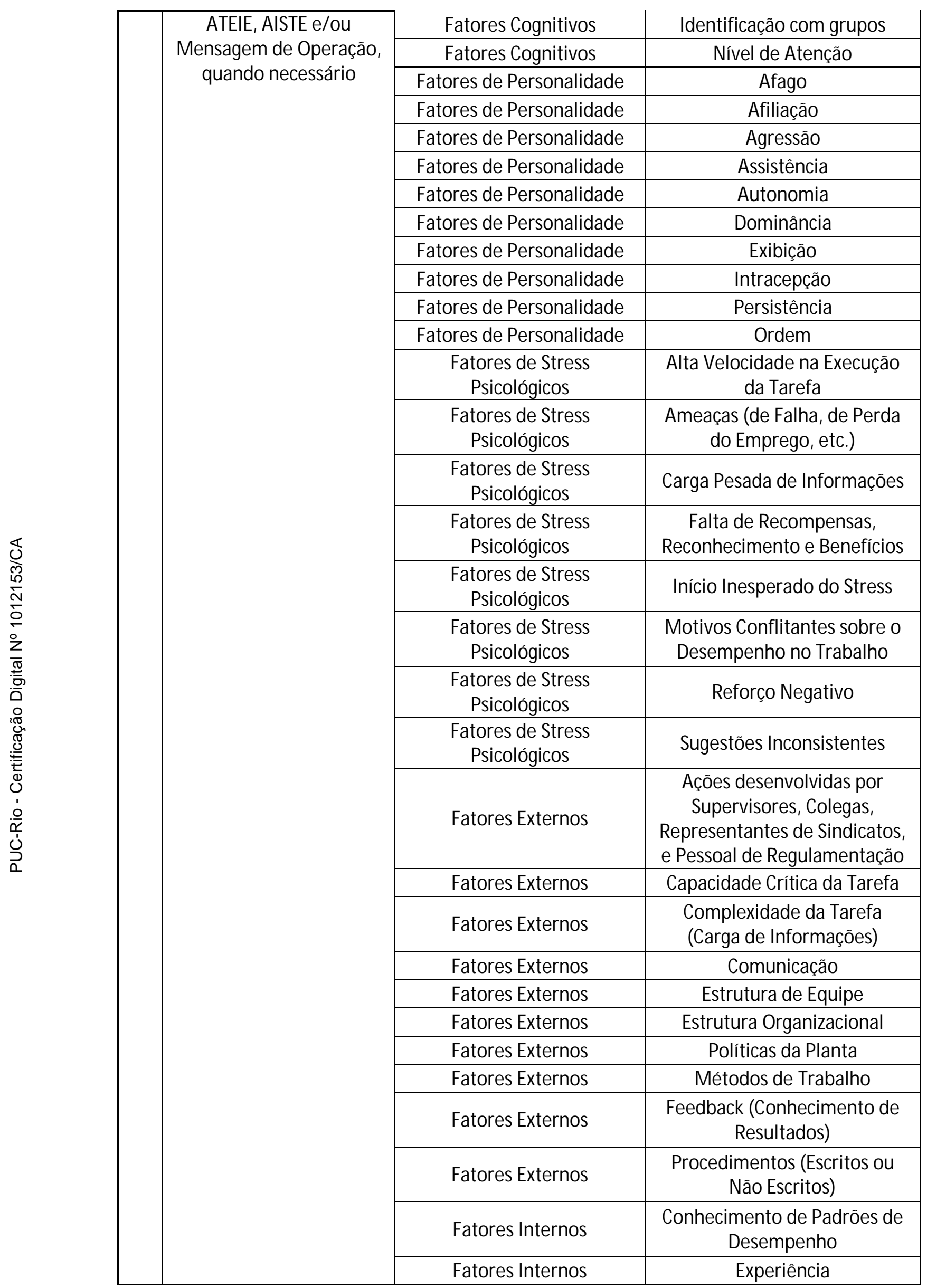




\begin{tabular}{|c|c|c|c|}
\hline & & Fatores Internos & Nível de cultura de segurança \\
\hline & & Fatores Internos & Nível de cultura organizacional \\
\hline & & Fatores Internos & Nível de práticas \\
\hline & & Fatores Internos & Qualidade do Treinamento \\
\hline & & Fatores Internos & Tensão Mental ou Física \\
\hline \multirow{25}{*}{10} & \multirow{25}{*}{$\begin{array}{c}\text { Executar as manobras } \\
\text { necessárias para } \\
\text { disponibilizar os } \\
\text { equipamentos para } \\
\text { operação }\end{array}$} & Fatores Cognitivos & Capacidade Analítica \\
\hline & & Fatores Cognitivos & $\begin{array}{c}\text { Capacidade de Tomada de } \\
\text { Decisões }\end{array}$ \\
\hline & & Fatores Cognitivos & Memória \\
\hline & & Fatores Cognitivos & Nível de Atenção \\
\hline & & Fatores de Personalidade & Afago \\
\hline & & Fatores de Personalidade & Ordem \\
\hline & & Fatores de Personalidade & Persistência \\
\hline & & $\begin{array}{l}\text { Fatores de Stress } \\
\text { Fisiológicos }\end{array}$ & Constrição de M ovimentos \\
\hline & & $\begin{array}{l}\text { Fatores de Stress } \\
\text { Fisiológicos }\end{array}$ & Dor ou Desconforto \\
\hline & & $\begin{array}{l}\text { Fatores de Stress } \\
\text { Fisiológicos }\end{array}$ & Exercício Físico \\
\hline & & $\begin{array}{l}\text { Fatores de Stress } \\
\text { Fisiológicos }\end{array}$ & Fadiga \\
\hline & & $\begin{array}{l}\text { Fatores de Stress } \\
\text { Fisiológicos }\end{array}$ & Fome ou Sede \\
\hline & & $\begin{array}{l}\text { Fatores de Stress } \\
\text { Fisiológicos }\end{array}$ & $\begin{array}{l}\text { Interrupção do Ritmo } \\
\text { Circadiano }\end{array}$ \\
\hline & & $\begin{array}{l}\text { Fatores de Stress } \\
\text { Fisiológicos }\end{array}$ & Longa Duração do Stress \\
\hline & & $\begin{array}{l}\text { Fatores de Stress } \\
\text { Fisiológicos }\end{array}$ & Repetição de M ovimentos \\
\hline & & $\begin{array}{l}\text { Fatores de Stress } \\
\text { Fisiológicos }\end{array}$ & Trabalho em Alturas \\
\hline & & $\begin{array}{l}\text { Fatores de Stress } \\
\text { Psicológicos }\end{array}$ & $\begin{array}{c}\text { Alta Velocidade na Execução } \\
\text { da Tarefa }\end{array}$ \\
\hline & & $\begin{array}{l}\text { Fatores de Stress } \\
\text { Psicológicos }\end{array}$ & $\begin{array}{c}\text { Ameaças (de Falha, de Perda } \\
\text { do Emprego, etc.) }\end{array}$ \\
\hline & & $\begin{array}{l}\text { Fatores de Stress } \\
\text { Psicológicos }\end{array}$ & Carga Pesada de Informações \\
\hline & & $\begin{array}{l}\text { Fatores de Stress } \\
\text { Psicológicos }\end{array}$ & $\begin{array}{l}\text { Distrações (devido a Ruído, } \\
\text { Clarão, M ovimentos, etc.) }\end{array}$ \\
\hline & & $\begin{array}{l}\text { Fatores de Stress } \\
\text { Psicológicos }\end{array}$ & $\begin{array}{c}\text { Falta de Recompensas, } \\
\text { Reconhecimento e Benefícios }\end{array}$ \\
\hline & & $\begin{array}{l}\text { Fatores de Stress } \\
\text { Psicológicos }\end{array}$ & Início Inesperado do Stress \\
\hline & & $\begin{array}{l}\text { Fatores de Stress } \\
\text { Psicológicos }\end{array}$ & $\begin{array}{l}\text { Motivos Conflitantes sobre o } \\
\text { Desempenho no Trabalho }\end{array}$ \\
\hline & & $\begin{array}{l}\text { Fatores de Stress } \\
\text { Psicológicos }\end{array}$ & Perda de Sensibilidade \\
\hline & & Fatores de Stress & Reforço Negativo \\
\hline
\end{tabular}




\begin{tabular}{|c|c|c|c|}
\hline & & Psicológicos & \\
\hline & & $\begin{array}{l}\text { Fatores de Stress } \\
\text { Psicológicos }\end{array}$ & Sugestões Inconsistentes \\
\hline & & Fatores Externos & Capacidade Crítica da Tarefa \\
\hline & & Fatores Externos & $\begin{array}{l}\text { Complexidade da Tarefa } \\
\text { (Carga de Informações) }\end{array}$ \\
\hline & & Fatores Externos & Cuidados e Advertências \\
\hline & & Fatores Externos & $\begin{array}{c}\text { Disponibilidade de } \\
\text { Equipamentos Especiais }\end{array}$ \\
\hline & & Fatores Externos & $\begin{array}{c}\text { Fatores de Interface de } \\
\text { Hardware }\end{array}$ \\
\hline & & Fatores Externos & $\begin{array}{l}\text { Freqüência e Repetitividade da } \\
\text { Tarefa }\end{array}$ \\
\hline & & Fatores Externos & Instrumentos \\
\hline & & Fatores Externos & $\begin{array}{l}\text { Feedback (Conhecimento de } \\
\text { Resultados) }\end{array}$ \\
\hline & & Fatores Externos & $\begin{array}{l}\text { Procedimentos (Escritos ou } \\
\text { Não Escritos) }\end{array}$ \\
\hline & & Fatores Internos & $\begin{array}{l}\text { Conhecimento de Padrões de } \\
\text { Desempenho }\end{array}$ \\
\hline & & Fatores Internos & Experiência \\
\hline & & Fatores Internos & Nível de cultura de segurança \\
\hline & & Fatores Internos & Nível de cultura organizacional \\
\hline & & Fatores Internos & Nível de práticas \\
\hline & & Fatores Internos & Qualidade do Treinamento \\
\hline & & Fatores Cognitivos & Capacidade de Classificação \\
\hline & & Fatores Cognitivos & Memória \\
\hline & & Fatores de Personalidade & Agressão \\
\hline & & Fatores de Personalidade & Autonomia \\
\hline & & Fatores de Personalidade & desempenho \\
\hline & & Fatores de Personalidade & Dominância \\
\hline & & Fatores de Personalidade & Ordem \\
\hline & & $\begin{array}{l}\text { Fatores de Stress } \\
\text { Psicológicos }\end{array}$ & Carga Pesada de Informações \\
\hline 11 & $\begin{array}{l}\text { de Operação do ONS } \\
\text { correspondente os }\end{array}$ & $\begin{array}{l}\text { Fatores de Stress } \\
\text { Psicológicos }\end{array}$ & $\begin{array}{l}\text { Períodos de Vigilância Longos, } \\
\text { sem Acontecimentos }\end{array}$ \\
\hline & $\begin{array}{l}\text { equipamentos para } \\
\text { operação }\end{array}$ & $\begin{array}{l}\text { Fatores de Stress } \\
\text { Psicológicos }\end{array}$ & Reforço Negativo \\
\hline & & $\begin{array}{l}\text { Fatores de Stress } \\
\text { Psicológicos }\end{array}$ & Sugestões Inconsistentes \\
\hline & & $\begin{array}{l}\text { Fatores de Stress } \\
\text { Psicológicos }\end{array}$ & $\begin{array}{c}\text { Trabalho M onótono, } \\
\text { Degradante ou Sem Sentido }\end{array}$ \\
\hline & & Fatores Externos & $\begin{array}{c}\text { Ações desenvolvidas por } \\
\text { Supervisores, Colegas, } \\
\text { Representantes de Sindicatos, } \\
\text { e Pessoal de Regulamentação }\end{array}$ \\
\hline & & Fatores Externos & Capacidade Crítica da Tarefa \\
\hline
\end{tabular}




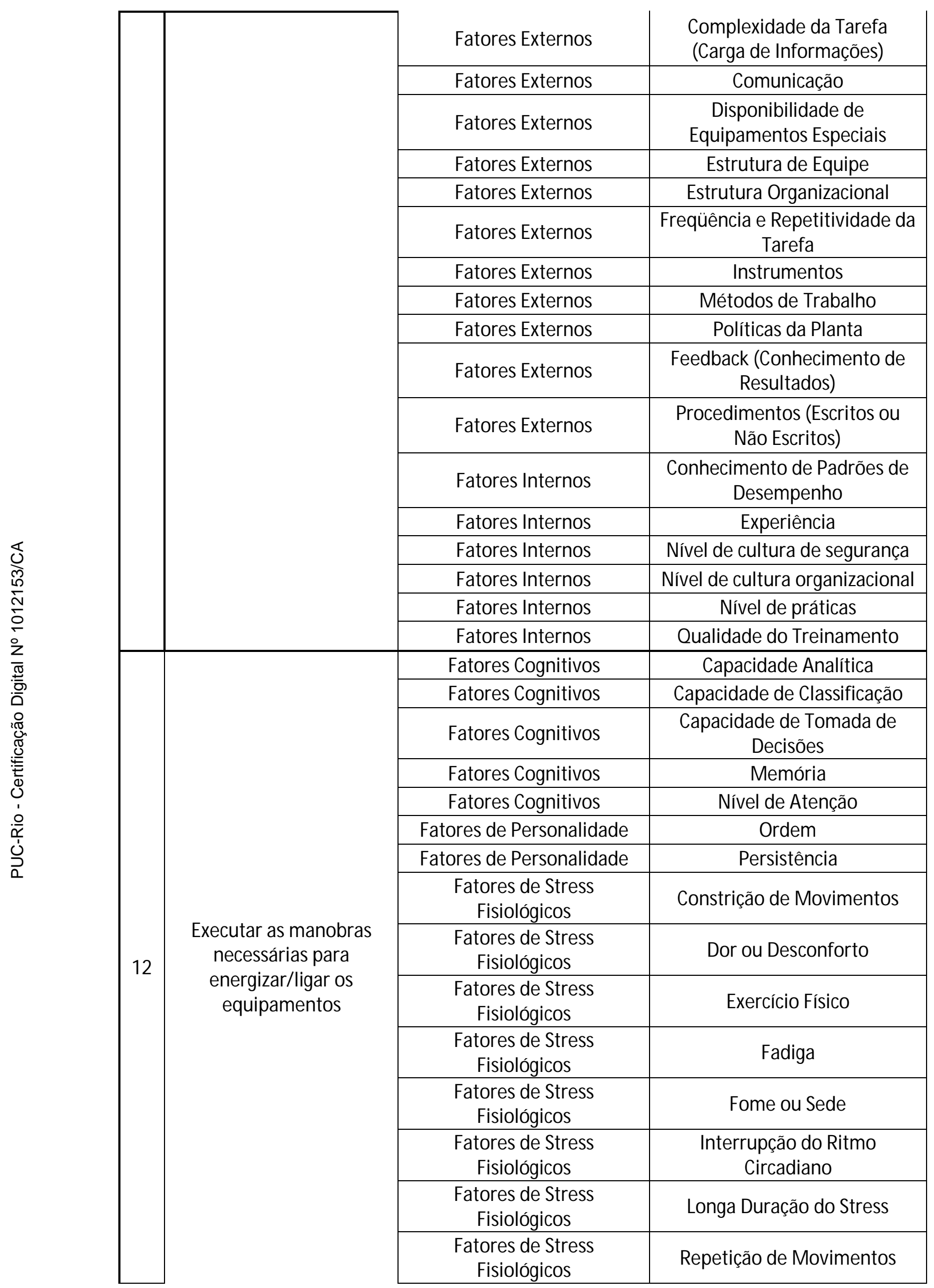




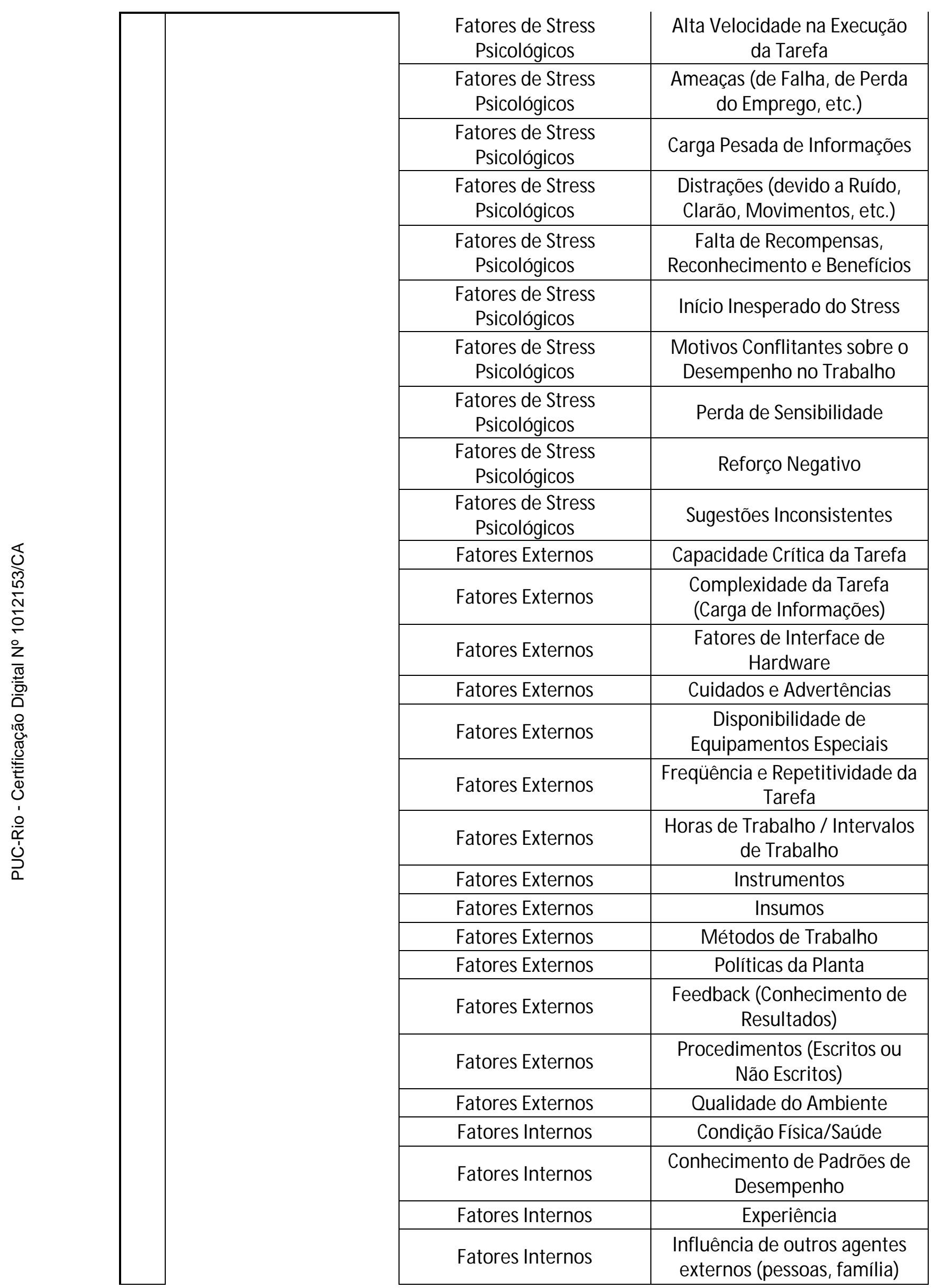




\begin{tabular}{|c|c|c|c|}
\hline & & Fatores Internos & M otivação \\
\hline & & Fatores Internos & Nível de cultura de segurança \\
\hline & & Fatores Internos & Nível de cultura organizacional \\
\hline & & Fatores Internos & Nível de práticas \\
\hline & & Fatores Internos & Qualidade do Treinamento \\
\hline & & Fatores Internos & Tensão M ental ou Física \\
\hline \multirow{27}{*}{13} & \multirow{27}{*}{$\begin{array}{l}\text { Liberar o início da } \\
\text { intervenção para o } \\
\text { responsável da } \\
\text { manutenção }\end{array}$} & Fatores Cognitivos & Identificação com grupos \\
\hline & & Fatores Cognitivos & Nível de Atenção \\
\hline & & Fatores de Personalidade & Afago \\
\hline & & Fatores de Personalidade & Afiliação \\
\hline & & Fatores de Personalidade & Agressão \\
\hline & & Fatores de Personalidade & Autonomia \\
\hline & & Fatores de Personalidade & Desempenho \\
\hline & & Fatores de Personalidade & Dominância \\
\hline & & Fatores de Personalidade & Ordem \\
\hline & & $\begin{array}{l}\text { Fatores de Stress } \\
\text { Fisiológicos }\end{array}$ & Fome ou Sede \\
\hline & & $\begin{array}{l}\text { Fatores de Stress } \\
\text { Fisiológicos }\end{array}$ & $\begin{array}{c}\text { Interrupção do Ritmo } \\
\text { Circadiano }\end{array}$ \\
\hline & & $\begin{array}{l}\text { Fatores de Stress } \\
\text { Psicológicos }\end{array}$ & $\begin{array}{c}\text { Ameaças (de Falha, de Perda } \\
\text { do Emprego, etc.) }\end{array}$ \\
\hline & & $\begin{array}{l}\text { Fatores de Stress } \\
\text { Psicológicos }\end{array}$ & Carga Pesada de Informações \\
\hline & & $\begin{array}{l}\text { Fatores de Stress } \\
\text { Psicológicos }\end{array}$ & $\begin{array}{c}\text { Falta de Recompensas, } \\
\text { Reconhecimento e Benefícios }\end{array}$ \\
\hline & & $\begin{array}{l}\text { Fatores de Stress } \\
\text { Psicológicos }\end{array}$ & Início Inesperado do Stress \\
\hline & & $\begin{array}{l}\text { Fatores de Stress } \\
\text { Psicológicos }\end{array}$ & $\begin{array}{l}\text { M otivos Conflitantes sobre o } \\
\text { Desempenho no Trabalho }\end{array}$ \\
\hline & & $\begin{array}{l}\text { Fatores de Stress } \\
\text { Psicológicos }\end{array}$ & $\begin{array}{l}\text { Períodos de Vigilância Longos, } \\
\text { sem Acontecimentos }\end{array}$ \\
\hline & & $\begin{array}{l}\text { Fatores de Stress } \\
\text { Psicológicos }\end{array}$ & Reforço Negativo \\
\hline & & $\begin{array}{l}\text { Fatores de Stress } \\
\text { Psicológicos }\end{array}$ & Sugestões Inconsistentes \\
\hline & & $\begin{array}{l}\text { Fatores de Stress } \\
\text { Psicológicos }\end{array}$ & $\begin{array}{l}\text { Trabalho M onótono, } \\
\text { Degradante ou Sem Sentido }\end{array}$ \\
\hline & & Fatores Externos & $\begin{array}{c}\text { Ações desenvolvidas por } \\
\text { Supervisores, Colegas, } \\
\text { Representantes de Sindicatos, } \\
\text { e Pessoal de Regulamentação }\end{array}$ \\
\hline & & Fatores Externos & Capacidade Crítica da Tarefa \\
\hline & & Fatores Externos & $\begin{array}{l}\text { Complexidade da Tarefa } \\
\text { (Carga de Informações) }\end{array}$ \\
\hline & & Fatores Externos & Comunicação \\
\hline & & Fatores Externos & Cuidados e Advertências \\
\hline & & Fatores Externos & Estrutura de Equipe \\
\hline & & Fatores Externos & Estrutura Organizacional \\
\hline
\end{tabular}




\begin{tabular}{|c|c|c|c|}
\hline & & Fatores Externos & $\begin{array}{l}\text { Feedback (Conhecimento de } \\
\text { Resultados) }\end{array}$ \\
\hline & & Fatores Externos & M étodos de Trabalho \\
\hline & & Fatores Externos & Políticas da Planta \\
\hline & & Fatores Externos & $\begin{array}{l}\text { Procedimentos (Escritos ou } \\
\text { Não Escritos) }\end{array}$ \\
\hline & & Fatores Internos & $\begin{array}{l}\text { Conhecimento de Padrões de } \\
\text { Desempenho }\end{array}$ \\
\hline & & Fatores Internos & Experiência \\
\hline & & Fatores Internos & Nível de cultura de segurança \\
\hline & & Fatores Internos & Nível de cultura organizacional \\
\hline & & Fatores Internos & Nível de práticas \\
\hline & & Fatores Internos & Qualidade do Treinamento \\
\hline & & Fatores Cognitivos & Identificação com grupos \\
\hline & & Fatores Cognitivos & Nível de Atenção \\
\hline & & Fatores de Personalidade & Afago \\
\hline & & Fatores de Personalidade & Afiliação \\
\hline & & Fatores de Personalidade & Agressão \\
\hline & & Fatores de Personalidade & Autonomia \\
\hline & & Fatores de Personalidade & Desempenho \\
\hline & & Fatores de Personalidade & Dominância \\
\hline & & Fatores de Personalidade & Ordem \\
\hline & & Fatores de Personalidade & Persistência \\
\hline$\frac{d}{\underline{\pi}}$ & & $\begin{array}{l}\text { Fatores de Stress } \\
\text { Psicológicos }\end{array}$ & $\begin{array}{c}\text { Alta Velocidade na Execução } \\
\text { da Tarefa }\end{array}$ \\
\hline 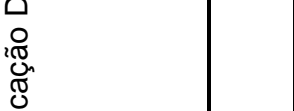 & & $\begin{array}{l}\text { Fatores de Stress } \\
\text { Psicológicos }\end{array}$ & Carga Pesada de Informações \\
\hline 吡 & $\begin{array}{l}\text { Receber do responsável } \\
\text { da manutencão as }\end{array}$ & $\begin{array}{l}\text { Fatores de Stress } \\
\text { Psicológicos }\end{array}$ & Início Inesperado do Stress \\
\hline 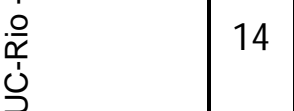 & $\begin{array}{l}\text { instalações livres para } \\
\text { operação (conclusão dos }\end{array}$ & $\begin{array}{l}\text { Fatores de Stress } \\
\text { Psicológicos }\end{array}$ & $\begin{array}{c}\text { Falta de Recompensas, } \\
\text { Reconhecimento e Benefícios }\end{array}$ \\
\hline & serviços) & $\begin{array}{l}\text { Fatores de Stress } \\
\text { Psicológicos }\end{array}$ & $\begin{array}{l}\text { Motivos Conflitantes sobre o } \\
\text { Desempenho no Trabalho }\end{array}$ \\
\hline & & $\begin{array}{l}\text { Fatores de Stress } \\
\text { Psicológicos }\end{array}$ & $\begin{array}{c}\text { Períodos de Vigilância Longos, } \\
\text { sem Acontecimentos }\end{array}$ \\
\hline & & $\begin{array}{l}\text { Fatores de Stress } \\
\text { Psicológicos }\end{array}$ & Reforço Negativo \\
\hline & & $\begin{array}{l}\text { Fatores de Stress } \\
\text { Psicológicos }\end{array}$ & Sugestões Inconsistentes \\
\hline & & $\begin{array}{l}\text { Fatores de Stress } \\
\text { Psicológicos }\end{array}$ & $\begin{array}{c}\text { Trabalho M onótono, } \\
\text { Degradante ou Sem Sentido }\end{array}$ \\
\hline & & Fatores Externos & $\begin{array}{c}\text { Ações desenvolvidas por } \\
\text { Supervisores, Colegas, } \\
\text { Representantes de Sindicatos, } \\
\text { e Pessoal de Regulamentação }\end{array}$ \\
\hline & & Fatores Externos & Comunicação \\
\hline & & Fatores Externos & Estrutura de Equipe \\
\hline
\end{tabular}




\begin{tabular}{|c|c|c|c|}
\hline & & Fatores Externos & Estrutura Organizacional \\
\hline & & Fatores Externos & Métodos de Trabalho \\
\hline & & Fatores Externos & Políticas da Planta \\
\hline & & Fatores Externos & $\begin{array}{l}\text { Procedimentos (Escritos ou } \\
\text { Não Escritos) }\end{array}$ \\
\hline & & Fatores Internos & Experiência \\
\hline & & Fatores Internos & Nível de cultura de segurança \\
\hline & & Fatores Internos & Nível de cultura organizacional \\
\hline & & Fatores Internos & Nível de práticas \\
\hline & & Fatores Internos & Qualidade do Treinamento \\
\hline \multirow{23}{*}{15} & \multirow{23}{*}{$\begin{array}{l}\text { Receber do responsável } \\
\text { da manutenção } \\
\text { solicitação para prorrogar } \\
\text { a intervenção }\end{array}$} & Fatores Cognitivos & Identificação com grupos \\
\hline & & Fatores Cognitivos & Nível de Atenção \\
\hline & & Fatores Cognitivos & $\begin{array}{l}\text { Inteligência numérica } \\
\text { (capacidade de cálculos) }\end{array}$ \\
\hline & & Fatores Cognitivos & Percepção de séries \\
\hline & & Fatores de Personalidade & Afago \\
\hline & & Fatores de Personalidade & Afiliação \\
\hline & & Fatores de Personalidade & Agressão \\
\hline & & Fatores de Personalidade & Autonomia \\
\hline & & Fatores de Personalidade & Desempenho \\
\hline & & Fatores de Personalidade & Dominância \\
\hline & & Fatores de Personalidade & Ordem \\
\hline & & $\begin{array}{l}\text { Fatores de Stress } \\
\text { Psicológicos }\end{array}$ & $\begin{array}{c}\text { Alta Velocidade na Execução } \\
\text { da Tarefa }\end{array}$ \\
\hline & & $\begin{array}{l}\text { Fatores de Stress } \\
\text { Psicológicos }\end{array}$ & Carga Pesada de Informações \\
\hline & & $\begin{array}{l}\text { Fatores de Stress } \\
\text { Psicológicos }\end{array}$ & Início Inesperado do Stress \\
\hline & & $\begin{array}{l}\text { Fatores de Stress } \\
\text { Psicológicos }\end{array}$ & $\begin{array}{c}\text { Ameaças (de Falha, de Perda } \\
\text { do Emprego, etc.) }\end{array}$ \\
\hline & & $\begin{array}{l}\text { Fatores de Stress } \\
\text { Psicológicos }\end{array}$ & $\begin{array}{c}\text { Falta de Recompensas, } \\
\text { Reconhecimento e Benefícios }\end{array}$ \\
\hline & & $\begin{array}{l}\text { Fatores de Stress } \\
\text { Psicológicos }\end{array}$ & $\begin{array}{l}\text { Motivos Conflitantes sobre o } \\
\text { Desempenho no Trabalho }\end{array}$ \\
\hline & & $\begin{array}{l}\text { Fatores de Stress } \\
\text { Psicológicos }\end{array}$ & $\begin{array}{l}\text { Períodos de Vigilância Longos, } \\
\text { sem Acontecimentos }\end{array}$ \\
\hline & & $\begin{array}{l}\text { Fatores de Stress } \\
\text { Psicológicos }\end{array}$ & Reforço Negativo \\
\hline & & $\begin{array}{l}\text { Fatores de Stress } \\
\text { Psicológicos }\end{array}$ & Sugestões Inconsistentes \\
\hline & & $\begin{array}{l}\text { Fatores de Stress } \\
\text { Psicológicos }\end{array}$ & $\begin{array}{l}\text { Trabalho M onótono, } \\
\text { Degradante ou Sem Sentido }\end{array}$ \\
\hline & & Fatores Externos & $\begin{array}{l}\text { Ações desenvolvidas por } \\
\text { Supervisores, Colegas, } \\
\text { Representantes de Sindicatos, } \\
\text { e Pessoal de Regulamentação }\end{array}$ \\
\hline & & Fatores Externos & Comunicação \\
\hline
\end{tabular}




\begin{tabular}{|c|c|c|c|}
\hline & & Fatores Externos & Estrutura de Equipe \\
\hline & & Fatores Externos & Estrutura Organizacional \\
\hline & & Fatores Externos & Métodos de Trabalho \\
\hline & & Fatores Externos & Políticas da Planta \\
\hline & & Fatores Externos & $\begin{array}{l}\text { Feedback (Conhecimento de } \\
\text { Resultados) }\end{array}$ \\
\hline & & Fatores Externos & $\begin{array}{l}\text { Procedimentos (Escritos ou } \\
\text { Não Escritos) }\end{array}$ \\
\hline & & Fatores Internos & $\begin{array}{l}\text { Conhecimento de Padrões de } \\
\text { Desempenho }\end{array}$ \\
\hline & & Fatores Internos & Experiência \\
\hline & & Fatores Internos & Nível de cultura de segurança \\
\hline & & Fatores Internos & Nível de cultura organizacional \\
\hline & & Fatores Internos & Nível de práticas \\
\hline & & Fatores Internos & Qualidade do Treinamento \\
\hline \multirow{21}{*}{16} & \multirow{21}{*}{$\begin{array}{l}\text { Receber do responsável } \\
\text { da manutenção } \\
\text { solicitação para } \\
\text { reprogramar a } \\
\text { intervenção }\end{array}$} & Fatores Cognitivos & Identificação com grupos \\
\hline & & Fatores Cognitivos & Nível de Atenção \\
\hline & & Fatores Cognitivos & $\begin{array}{l}\text { Inteligência numérica } \\
\text { (capacidade de cálculos) }\end{array}$ \\
\hline & & Fatores Cognitivos & Percepção de séries \\
\hline & & Fatores de Personalidade & Afago \\
\hline & & Fatores de Personalidade & Afiliação \\
\hline & & Fatores de Personalidade & Agressão \\
\hline & & Fatores de Personalidade & Autonomia \\
\hline & & Fatores de Personalidade & Desempenho \\
\hline & & Fatores de Personalidade & Dominância \\
\hline & & Fatores de Personalidade & Ordem \\
\hline & & Fatores de Personalidade & Persistência \\
\hline & & $\begin{array}{l}\text { Fatores de Stress } \\
\text { Psicológicos }\end{array}$ & $\begin{array}{c}\text { Alta Velocidade na Execução } \\
\text { da Tarefa }\end{array}$ \\
\hline & & $\begin{array}{l}\text { Fatores de Stress } \\
\text { Psicológicos }\end{array}$ & Carga Pesada de Informações \\
\hline & & $\begin{array}{l}\text { Fatores de Stress } \\
\text { Psicológicos }\end{array}$ & Início Inesperado do Stress \\
\hline & & $\begin{array}{l}\text { Fatores de Stress } \\
\text { Psicológicos }\end{array}$ & $\begin{array}{c}\text { Ameaças (de Falha, de Perda } \\
\text { do Emprego, etc.) }\end{array}$ \\
\hline & & $\begin{array}{l}\text { Fatores de Stress } \\
\text { Psicológicos }\end{array}$ & $\begin{array}{c}\text { Falta de Recompensas, } \\
\text { Reconhecimento e Benefícios }\end{array}$ \\
\hline & & $\begin{array}{l}\text { Fatores de Stress } \\
\text { Psicológicos }\end{array}$ & $\begin{array}{c}\text { Motivos Conflitantes sobre } 0 \\
\text { Desempenho no Trabalho }\end{array}$ \\
\hline & & $\begin{array}{l}\text { Fatores de Stress } \\
\text { Psicológicos }\end{array}$ & $\begin{array}{c}\text { Períodos de Vigilância Longos, } \\
\text { sem Acontecimentos }\end{array}$ \\
\hline & & $\begin{array}{l}\text { Fatores de Stress } \\
\text { Psicológicos }\end{array}$ & Reforço Negativo \\
\hline & & $\begin{array}{l}\text { Fatores de Stress } \\
\text { Psicológicos }\end{array}$ & Sugestões Inconsistentes \\
\hline
\end{tabular}




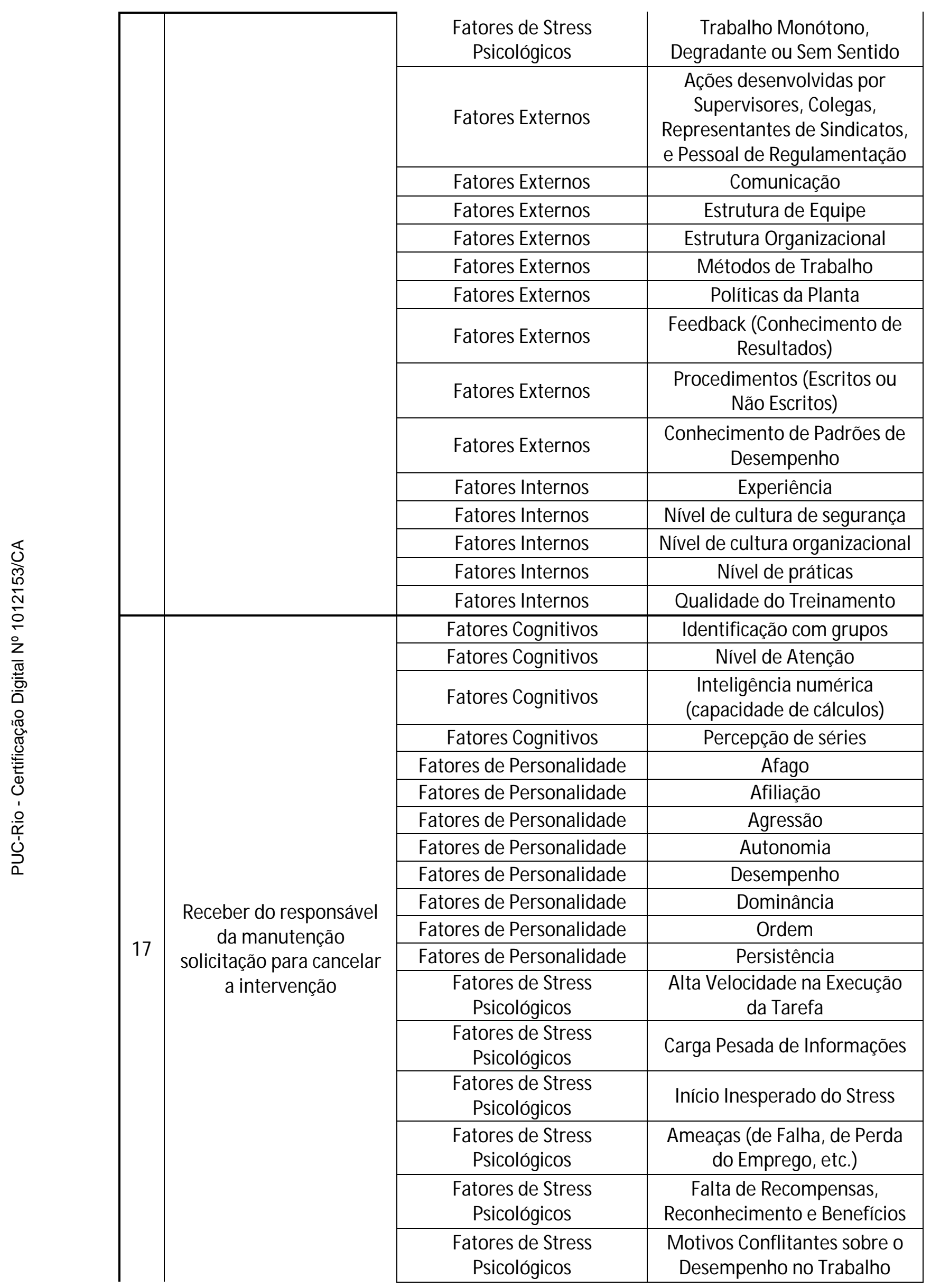




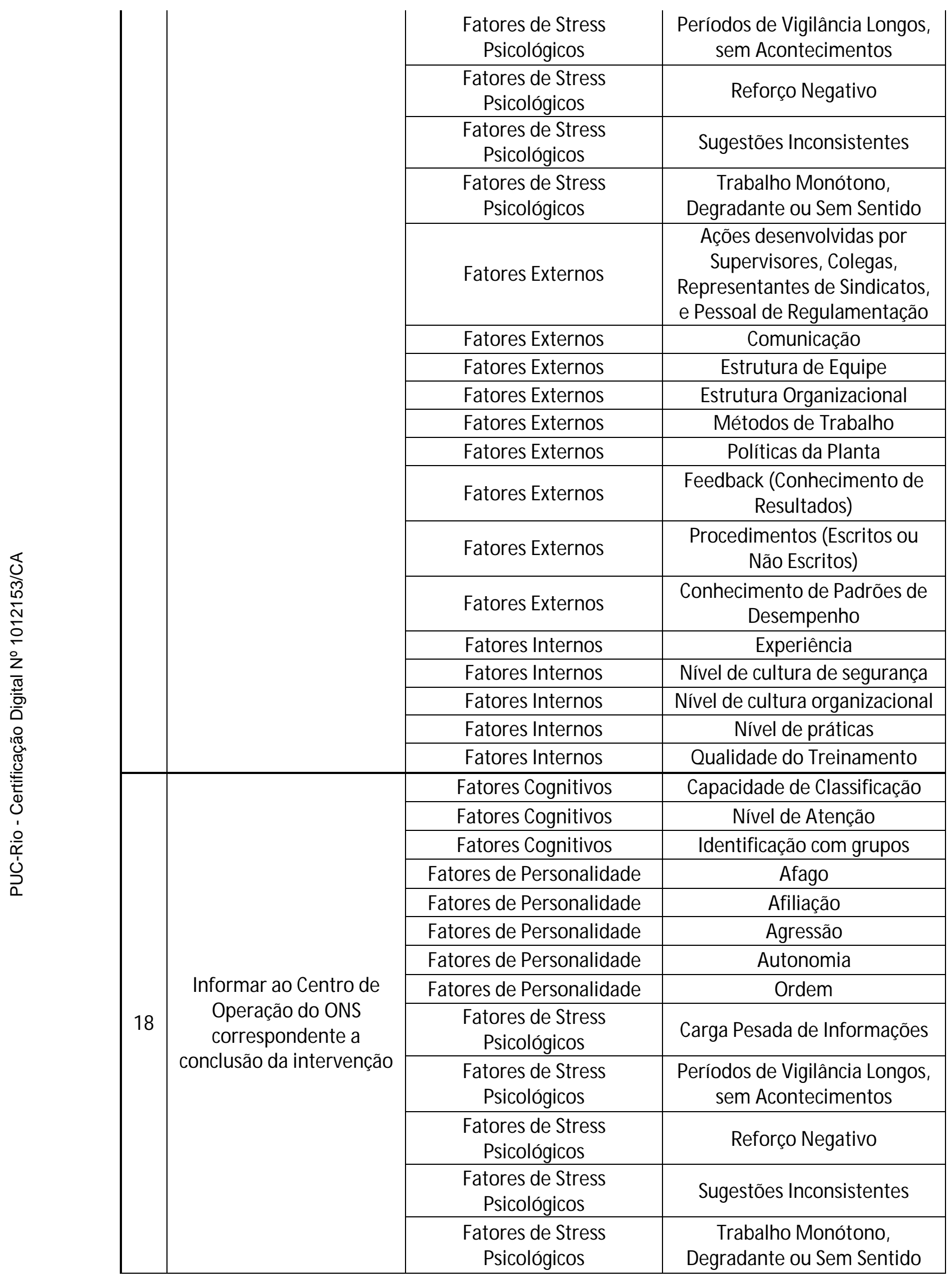




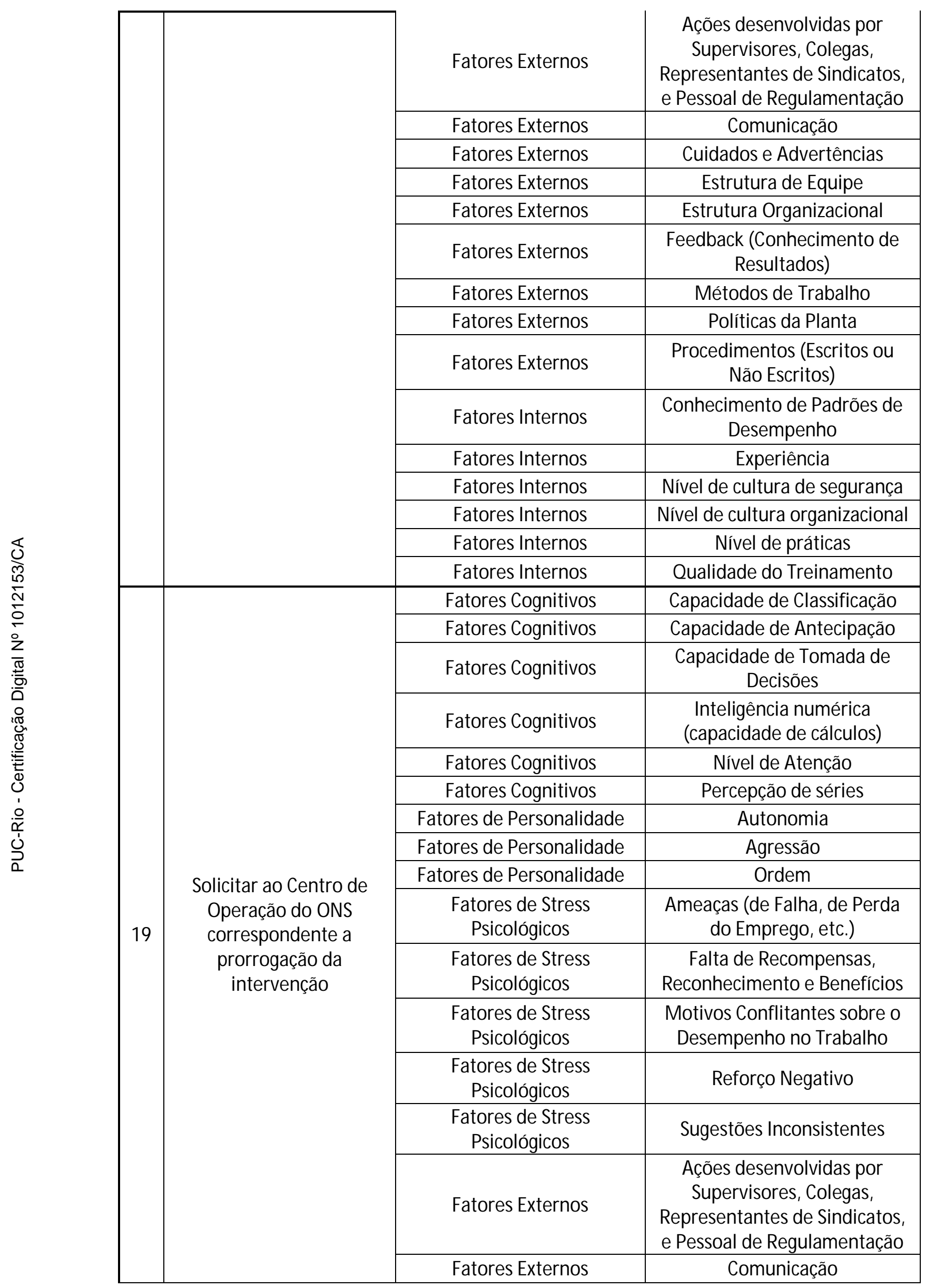




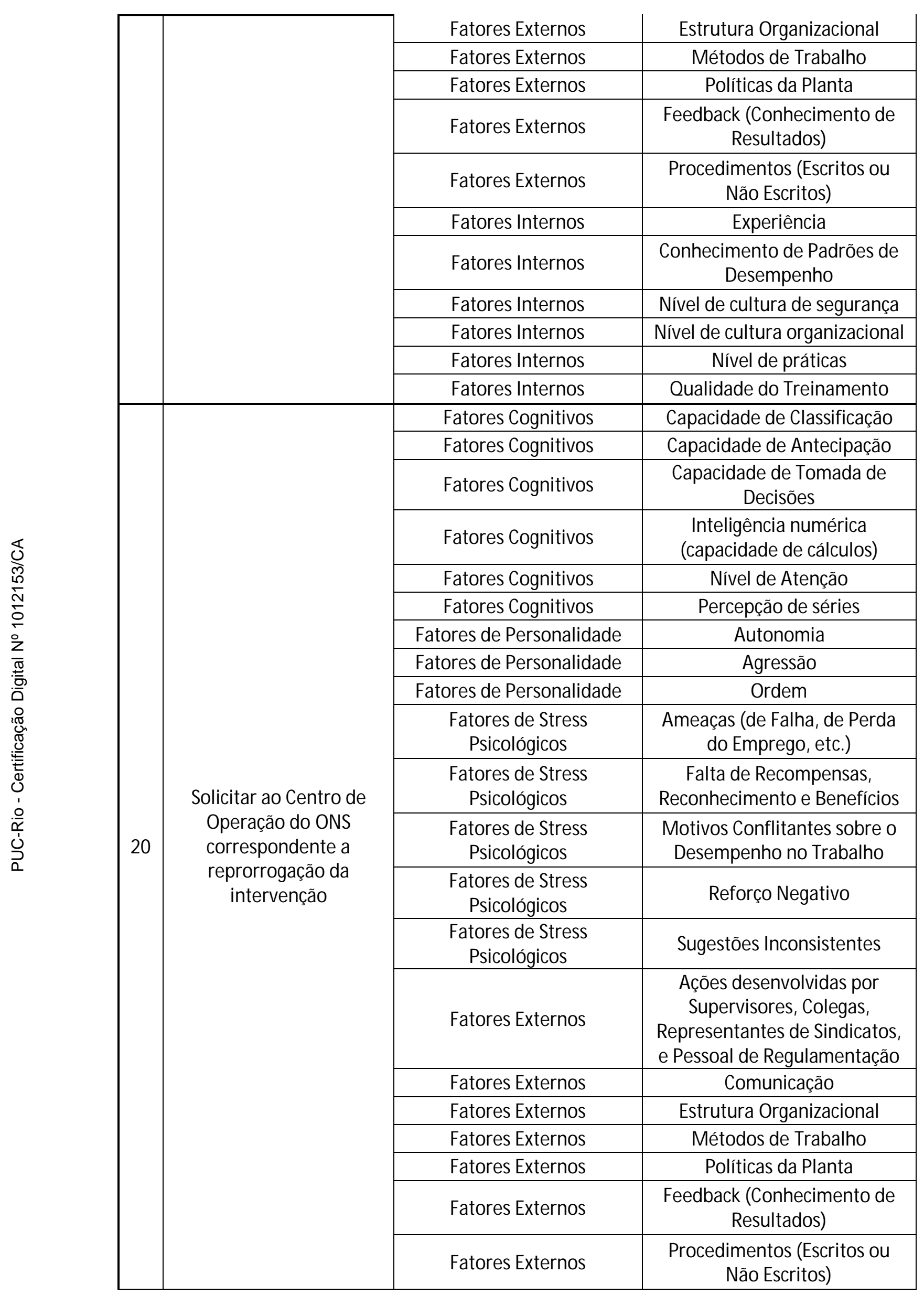




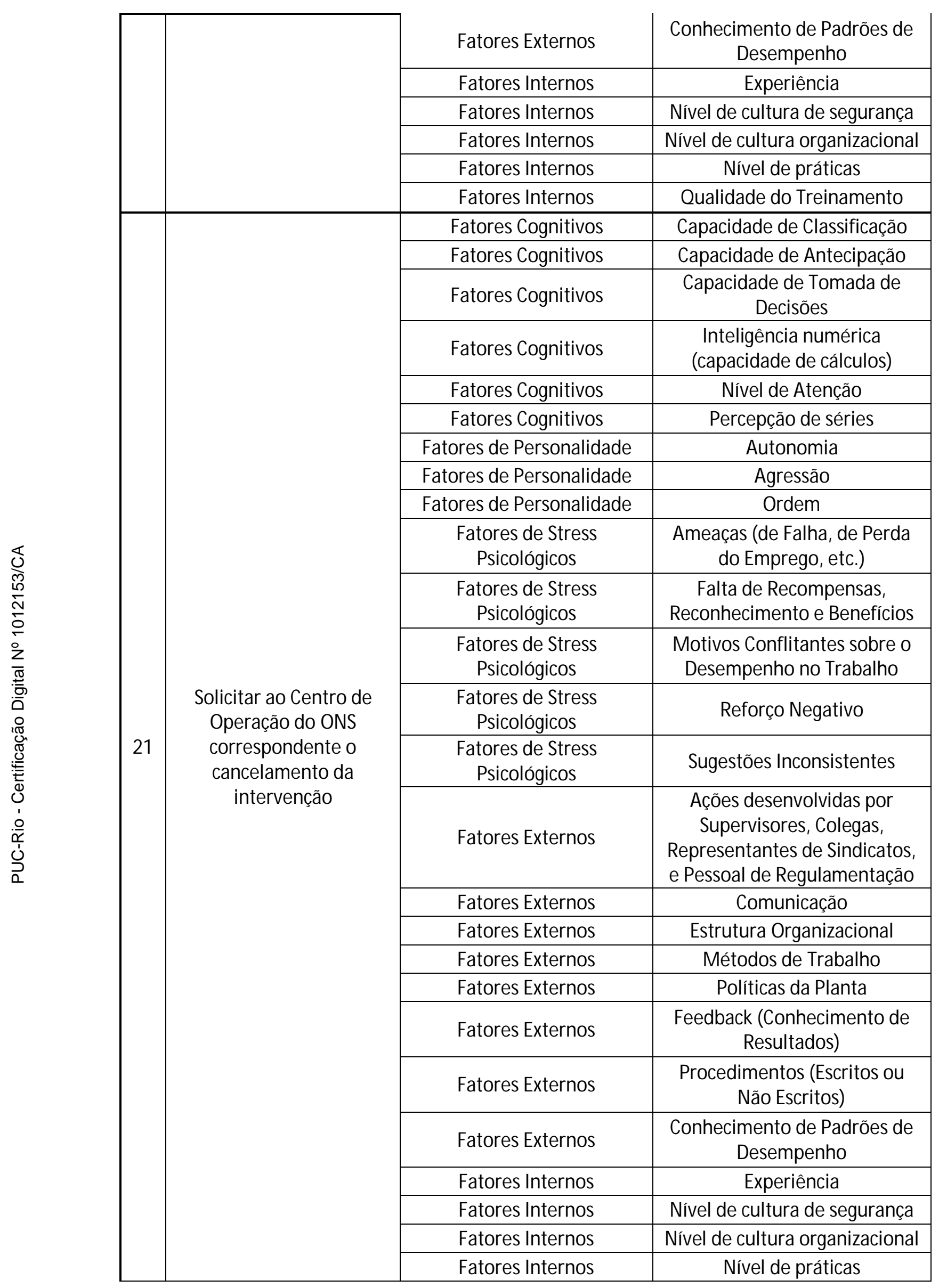




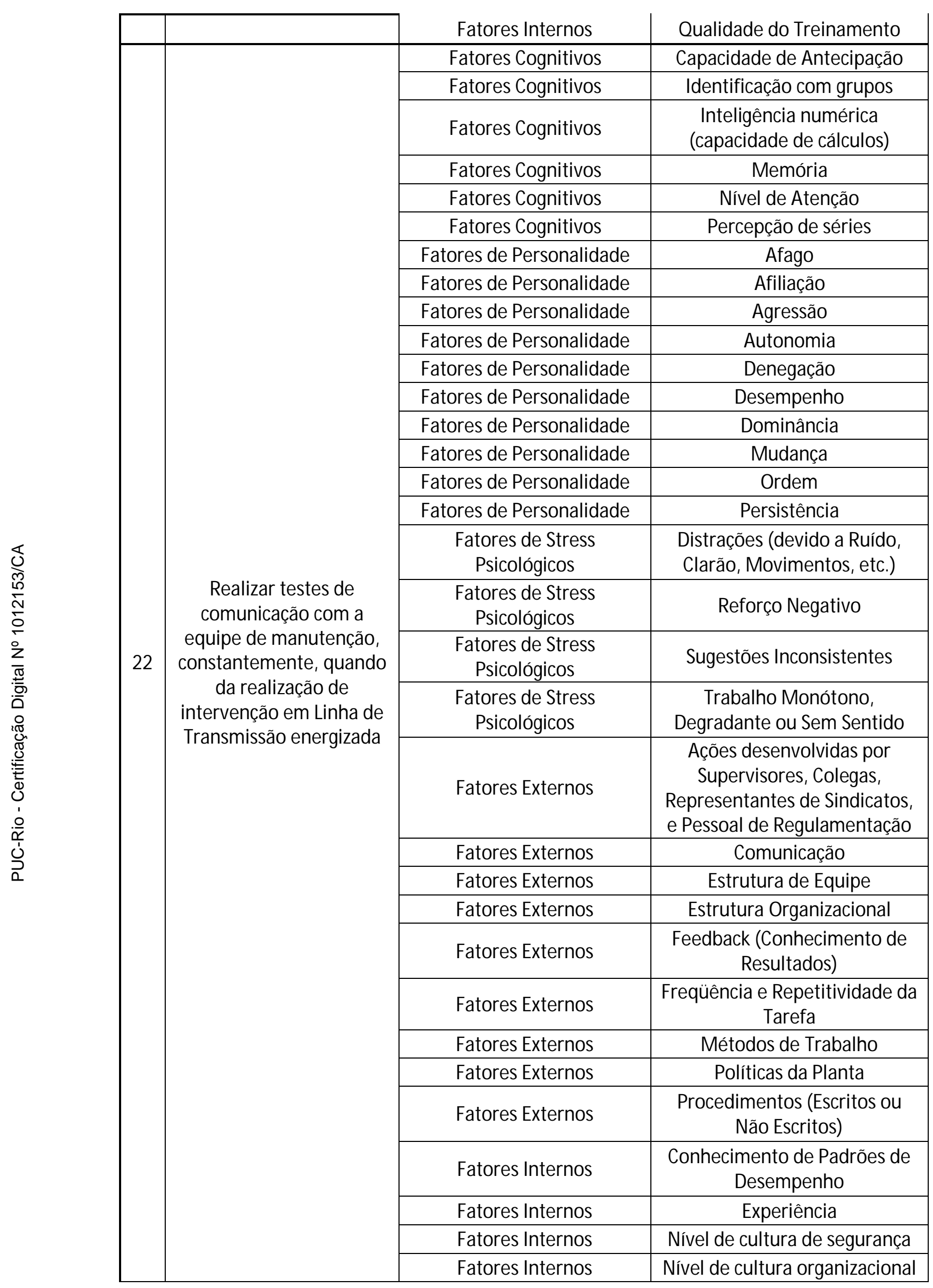




\begin{tabular}{|c|c|c|c|}
\hline & & Fatores Internos & Nível de práticas \\
\hline & & Fatores Internos & Qualidade do Treinamento \\
\hline & & Fatores Internos & M otivação \\
\hline & & Fatores Internos & Tensão M ental ou Física \\
\hline \multirow{28}{*}{23} & \multirow{28}{*}{$\begin{array}{l}\text { Executar manobras nos } \\
\text { equipamentos das } \\
\text { subestações de sua } \\
\text { responsabilidade sem } \\
\text { autorização do Centro de } \\
\text { Operação do ONS } \\
\text { correspondente (situação } \\
\text { de emergência) }\end{array}$} & Fatores Cognitivos & Capacidade Analítica \\
\hline & & Fatores Cognitivos & Capacidade de Classificação \\
\hline & & Fatores Cognitivos & Capacidade de Antecipação \\
\hline & & Fatores Cognitivos & $\begin{array}{l}\text { Capacidade de Tomada de } \\
\text { Decisões }\end{array}$ \\
\hline & & Fatores Cognitivos & $\begin{array}{l}\text { Inteligência numérica } \\
\text { (capacidade de cálculos) }\end{array}$ \\
\hline & & Fatores Cognitivos & Memória \\
\hline & & Fatores Cognitivos & Nível de Atenção \\
\hline & & Fatores de Personalidade & Afago \\
\hline & & Fatores de Personalidade & Afiliação \\
\hline & & Fatores de Personalidade & Autonomia \\
\hline & & Fatores de Personalidade & Desempenho \\
\hline & & Fatores de Personalidade & Exibição \\
\hline & & Fatores de Personalidade & Intracepção \\
\hline & & Fatores de Personalidade & Mudança \\
\hline & & Fatores de Personalidade & Ordem \\
\hline & & $\begin{array}{l}\text { Fatores de Stress } \\
\text { Fisiológicos }\end{array}$ & Exercício Físico \\
\hline & & $\begin{array}{c}\text { Fatores de Stress } \\
\text { Fisiológicos }\end{array}$ & Fadiga \\
\hline & & $\begin{array}{l}\text { Fatores de Stress } \\
\text { Psicológicos }\end{array}$ & $\begin{array}{c}\text { Alta Velocidade na Execução } \\
\text { da Tarefa }\end{array}$ \\
\hline & & $\begin{array}{l}\text { Fatores de Stress } \\
\text { Psicológicos }\end{array}$ & $\begin{array}{c}\text { Ameaças (de Falha, de Perda } \\
\text { do Emprego, etc.) }\end{array}$ \\
\hline & & $\begin{array}{l}\text { Fatores de Stress } \\
\text { Psicológicos }\end{array}$ & Carga Pesada de Informações \\
\hline & & $\begin{array}{l}\text { Fatores de Stress } \\
\text { Psicológicos }\end{array}$ & $\begin{array}{c}\text { Falta de Recompensas, } \\
\text { Reconhecimento e Benefícios }\end{array}$ \\
\hline & & $\begin{array}{l}\text { Fatores de Stress } \\
\text { Psicológicos }\end{array}$ & Início Inesperado do Stress \\
\hline & & $\begin{array}{l}\text { Fatores de Stress } \\
\text { Psicológicos }\end{array}$ & $\begin{array}{l}\text { Motivos Conflitantes sobre o } \\
\text { Desempenho no Trabalho }\end{array}$ \\
\hline & & $\begin{array}{l}\text { Fatores de Stress } \\
\text { Psicológicos }\end{array}$ & Reforço Negativo \\
\hline & & $\begin{array}{l}\text { Fatores de Stress } \\
\text { Psicológicos }\end{array}$ & Sugestões Inconsistentes \\
\hline & & Fatores Externos & $\begin{array}{c}\text { Ações desenvolvidas por } \\
\text { Supervisores, Colegas, } \\
\text { Representantes de Sindicatos, } \\
\text { e Pessoal de Regulamentação }\end{array}$ \\
\hline & & Fatores Externos & Capacidade Crítica da Tarefa \\
\hline & & Fatores Externos & Cuidados e Advertências \\
\hline
\end{tabular}




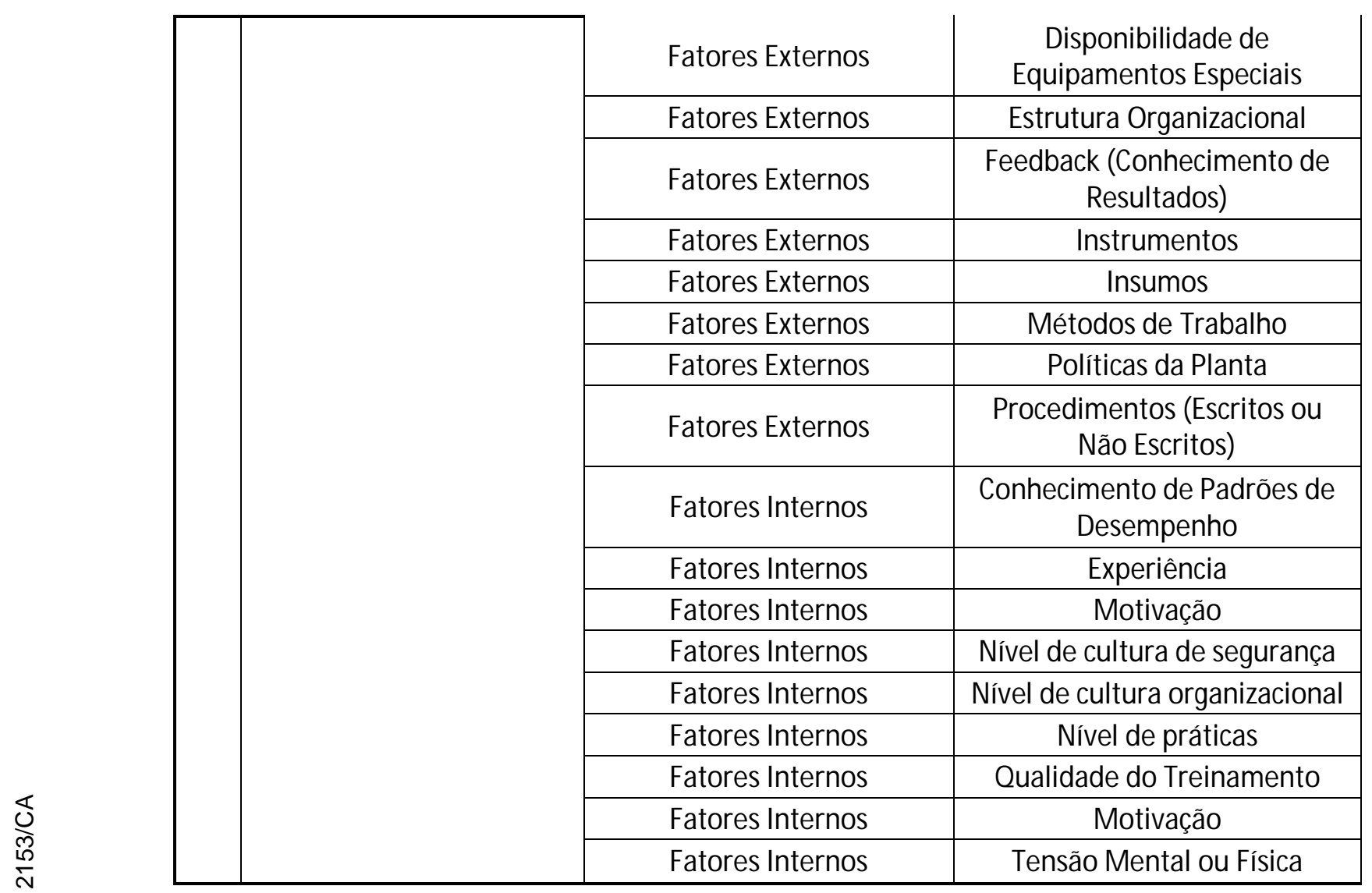

Tabela 16: Associação de tarefas do Procedimento para Execução de Intervenção com PSFs pertinentes

\begin{tabular}{|c|c|c|c|}
\hline \multicolumn{4}{|c|}{ Procedimento para Implantação de Documentação } \\
\hline & Tarefas & Grupo de PSFs & PSF \\
\hline \multirow{15}{*}{1} & \multirow{15}{*}{$\begin{array}{l}\text { Salvar documentos } \\
\text { atualizados em meio } \\
\text { digital }\end{array}$} & Fatores Cognitivos & Capacidade Analítica \\
\hline & & Fatores Cognitivos & Capacidade de Classificação \\
\hline & & Fatores Cognitivos & Memória \\
\hline & & Fatores Cognitivos & Nível de Atenção \\
\hline & & Fatores de Personalidade & Afago \\
\hline & & Fatores de Personalidade & Afiliação \\
\hline & & Fatores de Personalidade & Agressão \\
\hline & & Fatores de Personalidade & Autonomia \\
\hline & & Fatores de Personalidade & Ordem \\
\hline & & $\begin{array}{l}\text { Fatores de Stress } \\
\text { Psicológicos }\end{array}$ & Carga Pesada de Informações \\
\hline & & $\begin{array}{l}\text { Fatores de Stress } \\
\text { Psicológicos }\end{array}$ & Início Inesperado do Stress \\
\hline & & $\begin{array}{l}\text { Fatores de Stress } \\
\text { Psicológicos }\end{array}$ & $\begin{array}{c}\text { Trabalho M onótono, } \\
\text { Degradante ou Sem Sentido }\end{array}$ \\
\hline & & Fatores Externos & Estrutura Organizacional \\
\hline & & Fatores Externos & Métodos de Trabalho \\
\hline & & Fatores Externos & Políticas da Planta \\
\hline
\end{tabular}




\begin{tabular}{|c|c|c|c|}
\hline & & Fatores Externos & $\begin{array}{l}\text { Procedimentos (Escritos ou } \\
\text { Não Escritos) }\end{array}$ \\
\hline & & Fatores Internos & Nível de cultura de segurança \\
\hline & & Fatores Internos & Nível de cultura organizacional \\
\hline & & Fatores Internos & Nível de práticas \\
\hline & & Fatores Internos & Qualidade do Treinamento \\
\hline & & Fatores Cognitivos & Capacidade Analítica \\
\hline & & Fatores Cognitivos & Capacidade de Classificação \\
\hline & & Fatores Cognitivos & Memória \\
\hline & & Fatores Cognitivos & Nível de Atenção \\
\hline & & Fatores de Personalidade & Afago \\
\hline & & Fatores de Personalidade & Afiliação \\
\hline & & Fatores de Personalidade & Agressão \\
\hline & & Fatores de Personalidade & Autonomia \\
\hline & & Fatores de Personalidade & Ordem \\
\hline & & $\begin{array}{l}\text { Fatores de Stress } \\
\text { Psicológicos }\end{array}$ & Carga Pesada de Informações \\
\hline 2 & $\begin{array}{l}\text { Imprimir documentos } \\
\text { atualizados }\end{array}$ & $\begin{array}{l}\text { Fatores de Stress } \\
\text { Psicológicos }\end{array}$ & Início Inesperado do Stress \\
\hline & & $\begin{array}{l}\text { Fatores de Stress } \\
\text { Psicológicos }\end{array}$ & $\begin{array}{c}\text { Trabalho M onótono, } \\
\text { Degradante ou Sem Sentido }\end{array}$ \\
\hline & & Fatores Externos & Estrutura Organizacional \\
\hline & & Fatores Externos & Métodos de Trabalho \\
\hline & & Fatores Externos & Políticas da Planta \\
\hline 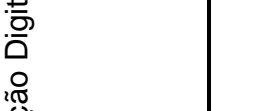 & & Fatores Externos & $\begin{array}{c}\text { Procedimentos (Escritos ou } \\
\text { Não Escritos) }\end{array}$ \\
\hline & & Fatores Internos & Nível de cultura de segurança \\
\hline & & Fatores Internos & Nível de cultura organizacional \\
\hline & & Fatores Internos & Nível de práticas \\
\hline & & Fatores Internos & Qualidade do Treinamento \\
\hline & & Fatores Cognitivos & Capacidade Analítica \\
\hline & & Fatores Cognitivos & Capacidade de Classificação \\
\hline & & Fatores Cognitivos & Memória \\
\hline & & Fatores Cognitivos & Nível de Atenção \\
\hline & & Fatores de Personalidade & Afago \\
\hline & & Fatores de Personalidade & Afiliação \\
\hline & & Fatores de Personalidade & Agressão \\
\hline 3 & Arquivar documentos & Fatores de Personalidade & Autonomia \\
\hline & atualizados em papel & Fatores de Personalidade & Ordem \\
\hline & & $\begin{array}{l}\text { Fatores de Stress } \\
\text { Psicológicos }\end{array}$ & Carga Pesada de Informações \\
\hline & & $\begin{array}{l}\text { Fatores de Stress } \\
\text { Psicológicos }\end{array}$ & Início Inesperado do Stress \\
\hline & & $\begin{array}{l}\text { Fatores de Stress } \\
\text { Psicológicos }\end{array}$ & $\begin{array}{l}\text { Trabalho M onótono, } \\
\text { Degradante ou Sem Sentido }\end{array}$ \\
\hline & & Fatores Externos & Estrutura Organizacional \\
\hline
\end{tabular}




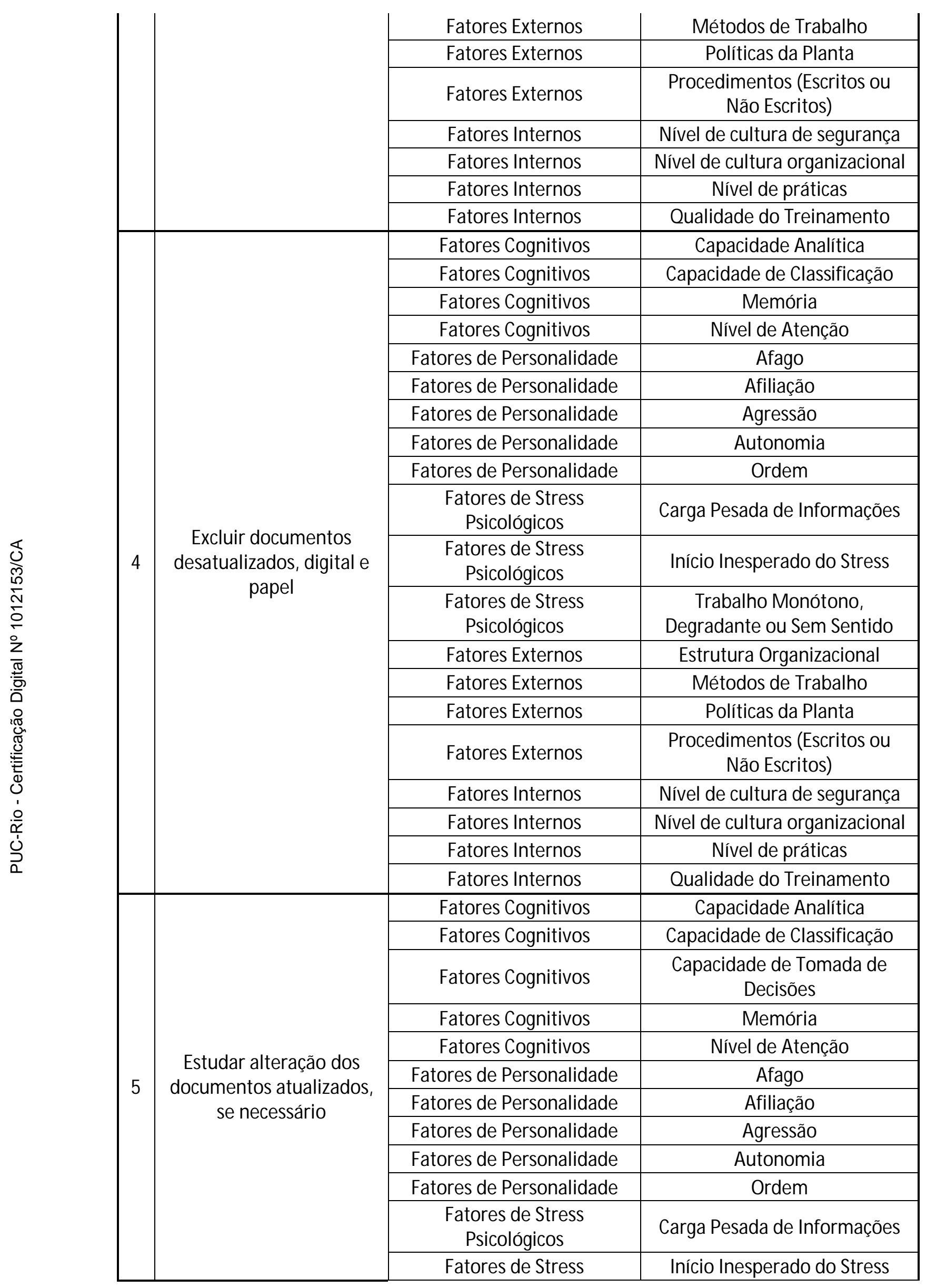




\begin{tabular}{|c|c|}
\hline Psicológicos & \\
\hline $\begin{array}{l}\text { Fatores de Stress } \\
\text { Psicológicos }\end{array}$ & $\begin{array}{c}\text { Trabalho M onótono, } \\
\text { Degradante ou Sem Sentido }\end{array}$ \\
\hline Fatores Externos & Estrutura Organizacional \\
\hline Fatores Externos & Métodos de Trabalho \\
\hline Fatores Externos & Políticas da Planta \\
\hline Fatores Externos & $\begin{array}{c}\text { Procedimentos (Escritos ou } \\
\text { Não Escritos) }\end{array}$ \\
\hline Fatores Internos & Nível de cultura de segurança \\
\hline Fatores Internos & Nível de cultura organizacional \\
\hline Fatores Internos & Nível de práticas \\
\hline Fatores Internos & Qualidade do Treinamento \\
\hline
\end{tabular}

Tabela 17: Associação de tarefas do Procedimento para Implantação de

Documentação com PSFs pertinentes

\begin{tabular}{|c|c|c|c|}
\hline \multicolumn{4}{|c|}{ Procedimento para Registros de Operação } \\
\hline & Tarefas & Grupo de PSFs & PSF \\
\hline \multirow{18}{*}{1} & \multirow{18}{*}{$\begin{array}{l}\text { Preencher o Livro de } \\
\text { Ocorrências }\end{array}$} & Fatores Cognitivos & Memória \\
\hline & & Fatores Cognitivos & Nível de Atenção \\
\hline & & Fatores de Personalidade & Afago \\
\hline & & Fatores de Personalidade & Afiliação \\
\hline & & Fatores de Personalidade & Autonomia \\
\hline & & Fatores de Personalidade & Ordem \\
\hline & & $\begin{array}{l}\text { Fatores de Stress } \\
\text { Psicológicos }\end{array}$ & Carga Pesada de Informações \\
\hline & & $\begin{array}{l}\text { Fatores de Stress } \\
\text { Psicológicos }\end{array}$ & $\begin{array}{c}\text { Ameaças (de Falha, de Perda } \\
\text { do Emprego, etc.) }\end{array}$ \\
\hline & & $\begin{array}{l}\text { Fatores de Stress } \\
\text { Psicológicos }\end{array}$ & $\begin{array}{l}\text { Motivos Conflitantes sobre } 0 \\
\text { Desempenho no Trabalho }\end{array}$ \\
\hline & & $\begin{array}{l}\text { Fatores de Stress } \\
\text { Psicológicos }\end{array}$ & $\begin{array}{c}\text { Falta de Recompensas, } \\
\text { Reconhecimento e Benefícios }\end{array}$ \\
\hline & & $\begin{array}{l}\text { Fatores de Stress } \\
\text { Psicológicos }\end{array}$ & Início Inesperado do Stress \\
\hline & & $\begin{array}{l}\text { Fatores de Stress } \\
\text { Psicológicos }\end{array}$ & Reforço Negativo \\
\hline & & $\begin{array}{l}\text { Fatores de Stress } \\
\text { Psicológicos }\end{array}$ & Sugestões Inconsistentes \\
\hline & & $\begin{array}{l}\text { Fatores de Stress } \\
\text { Psicológicos }\end{array}$ & $\begin{array}{c}\text { Trabalho M onótono, } \\
\text { Degradante ou Sem Sentido }\end{array}$ \\
\hline & & Fatores Externos & $\begin{array}{c}\text { Ações desenvolvidas por } \\
\text { Supervisores, Colegas, } \\
\text { Representantes de Sindicatos, } \\
\text { e Pessoal de Regulamentação }\end{array}$ \\
\hline & & Fatores Externos & Capacidade Crítica da Tarefa \\
\hline & & Fatores Externos & $\begin{array}{c}\text { Complexidade da Tarefa (Carga } \\
\text { de Informações) }\end{array}$ \\
\hline & & Fatores Externos & Comunicação \\
\hline
\end{tabular}




\begin{tabular}{|c|c|c|c|}
\hline & & Fatores Externos & Cuidados e Advertências \\
\hline & & Fatores Externos & Instrumentos \\
\hline & & Fatores Externos & Insumos \\
\hline & & Fatores Externos & $\begin{array}{c}\text { Disponibilidade de } \\
\text { Equipamentos Especiais }\end{array}$ \\
\hline & & Fatores Externos & Estrutura Organizacional \\
\hline & & Fatores Externos & $\begin{array}{l}\text { Freqüência e Repetitividade da } \\
\text { Tarefa }\end{array}$ \\
\hline & & Fatores Externos & Métodos de Trabalho \\
\hline & & Fatores Externos & Políticas da Planta \\
\hline & & Fatores Internos & $\begin{array}{l}\text { Feedback (Conhecimento de } \\
\text { Resultados) }\end{array}$ \\
\hline & & Fatores Externos & $\begin{array}{c}\text { Procedimentos (Escritos ou } \\
\text { Não Escritos) }\end{array}$ \\
\hline & & Fatores Internos & $\begin{array}{c}\text { Conhecimento de Padrões de } \\
\text { Desempenho }\end{array}$ \\
\hline & & Fatores Internos & Experiência \\
\hline & & Fatores Internos & Nível de cultura de segurança \\
\hline & & Fatores Internos & Nível de cultura organizacional \\
\hline & & Fatores Internos & Nível de práticas \\
\hline ల్ల & & Fatores Internos & Qualidade do Treinamento \\
\hline & & Fatores Internos & Tensão M ental ou Física \\
\hline$\frac{5}{0}$ & & Fatores Cognitivos & $\begin{array}{c}\text { Capacidade de Tomada de } \\
\text { Decisões }\end{array}$ \\
\hline & & Fatores Cognitivos & Identificação com grupos \\
\hline 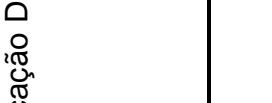 & & Fatores Cognitivos & $\begin{array}{l}\text { Inteligência numérica } \\
\text { (capacidade de cálculos) }\end{array}$ \\
\hline & & Fatores Cognitivos & Memória \\
\hline$\bigcup_{1}^{0}$ & & Fatores Cognitivos & Nível de Atenção \\
\hline.$ㅇ$ & & Fatores Cognitivos & Percepção de séries \\
\hline & & Fatores Cognitivos & $\begin{array}{l}\text { Predisposição para novos } \\
\text { conhecimentos }\end{array}$ \\
\hline & & Fatores de Personalidade & Afago \\
\hline 2 & Elaborar Relatório Diário & Fatores de Personalidade & Afiliação \\
\hline & & Fatores de Personalidade & Agressão \\
\hline & & Fatores de Personalidade & Assistência \\
\hline & & Fatores de Personalidade & Autonomia \\
\hline & & Fatores de Personalidade & Deferência \\
\hline & & Fatores de Personalidade & Exibição \\
\hline & & Fatores de Personalidade & Intracepção \\
\hline & & Fatores de Personalidade & Mudança \\
\hline & & Fatores de Personalidade & Ordem \\
\hline & & Fatores de Personalidade & Persistência \\
\hline & & $\begin{array}{l}\text { Fatores de Stress } \\
\text { Psicológicos }\end{array}$ & $\begin{array}{c}\text { Alta Velocidade na Execução da } \\
\text { Tarefa }\end{array}$ \\
\hline
\end{tabular}




\begin{tabular}{|c|c|c|c|}
\hline & & $\begin{array}{l}\text { Fatores de Stress } \\
\text { Psicológicos }\end{array}$ & $\begin{array}{c}\text { Ameaças (de Falha, de Perda } \\
\text { do Emprego, etc.) }\end{array}$ \\
\hline & & $\begin{array}{l}\text { Fatores de Stress } \\
\text { Psicológicos }\end{array}$ & Carga Pesada de Informações \\
\hline & & $\begin{array}{l}\text { Fatores de Stress } \\
\text { Psicológicos }\end{array}$ & $\begin{array}{c}\text { Falta de Recompensas, } \\
\text { Reconhecimento e Benefícios }\end{array}$ \\
\hline & & $\begin{array}{l}\text { Fatores de Stress } \\
\text { Psicológicos }\end{array}$ & Início Inesperado do Stress \\
\hline & & $\begin{array}{l}\text { Fatores de Stress } \\
\text { Psicológicos }\end{array}$ & $\begin{array}{c}\text { Motivos Conflitantes sobre } 0 \\
\text { Desempenho no Trabalho }\end{array}$ \\
\hline & & $\begin{array}{l}\text { Fatores de Stress } \\
\text { Psicológicos }\end{array}$ & Reforço Negativo \\
\hline & & $\begin{array}{l}\text { Fatores de Stress } \\
\text { Psicológicos }\end{array}$ & Sugestões Inconsistentes \\
\hline & & $\begin{array}{l}\text { Fatores de Stress } \\
\text { Psicológicos }\end{array}$ & $\begin{array}{c}\text { Trabalho M onótono, } \\
\text { Degradante ou Sem Sentido }\end{array}$ \\
\hline & & Fatores Externos & $\begin{array}{c}\text { Ações desenvolvidas por } \\
\text { Supervisores, Colegas, } \\
\text { Representantes de Sindicatos, } \\
\text { e Pessoal de Regulamentação }\end{array}$ \\
\hline & & Fatores Externos & Capacidade Crítica da Tarefa \\
\hline 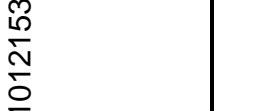 & & Fatores Externos & $\begin{array}{c}\text { Complexidade da Tarefa (Carga } \\
\text { de Informações) }\end{array}$ \\
\hline ò & & Fatores Externos & Comunicação \\
\hline$\overline{\bar{\pi}}$ & & Fatores Externos & Cuidados e Advertências \\
\hline "임 & & Fatores Externos & Estrutura de Equipe \\
\hline I্: & & Fatores Externos & Estrutura Organizacional \\
\hline 总 & & Fatores Externos & $\begin{array}{c}\text { Feedback (Conhecimento de } \\
\text { Resultados) }\end{array}$ \\
\hline ó & & Fatores Externos & Métodos de Trabalho \\
\hline & & Fatores Externos & Políticas da Planta \\
\hline$\stackrel{2}{2}$ & & Fatores Externos & $\begin{array}{l}\text { Procedimentos (Escritos ou } \\
\text { Não Escritos) }\end{array}$ \\
\hline & & Fatores Internos & $\begin{array}{c}\text { Conhecimento de Padrões de } \\
\text { Desempenho }\end{array}$ \\
\hline & & Fatores Internos & Experiência \\
\hline & & Fatores Internos & Motivação \\
\hline & & Fatores Internos & Nível de cultura de segurança \\
\hline & & Fatores Internos & Nível de cultura organizacional \\
\hline & & Fatores Internos & Nível de práticas \\
\hline & & Fatores Internos & Qualidade do Treinamento \\
\hline & & Fatores Internos & Tensão M ental ou Física \\
\hline & & Fatores Cognitivos & $\begin{array}{c}\text { Capacidade de Tomada de } \\
\text { Decisões }\end{array}$ \\
\hline 3 & de Oneracão - RDO & Fatores Cognitivos & Identificação com grupos \\
\hline & & Fatores Cognitivos & $\begin{array}{l}\text { Inteligência numérica } \\
\text { (capacidade de cálculos) }\end{array}$ \\
\hline
\end{tabular}




\begin{tabular}{|c|c|c|}
\hline & Fatores Cognitivos & Memória \\
\hline & Fatores Cognitivos & Nível de Atenção \\
\hline & Fatores Cognitivos & Percepção de séries \\
\hline & Fatores Cognitivos & $\begin{array}{l}\text { Predisposição para novos } \\
\text { conhecimentos }\end{array}$ \\
\hline & Fatores de Personalidade & Afago \\
\hline & Fatores de Personalidade & Afiliação \\
\hline & Fatores de Personalidade & Agressão \\
\hline & Fatores de Personalidade & Assistência \\
\hline & Fatores de Personalidade & Autonomia \\
\hline & Fatores de Personalidade & Deferência \\
\hline & Fatores de Personalidade & Exibição \\
\hline & Fatores de Personalidade & Intracepção \\
\hline & Fatores de Personalidade & Mudança \\
\hline & Fatores de Personalidade & Ordem \\
\hline & Fatores de Personalidade & Persistência \\
\hline & $\begin{array}{l}\text { Fatores de Stress } \\
\text { Psicológicos }\end{array}$ & $\begin{array}{c}\text { Alta Velocidade na Execução da } \\
\text { Tarefa }\end{array}$ \\
\hline & $\begin{array}{l}\text { Fatores de Stress } \\
\text { Psicológicos }\end{array}$ & $\begin{array}{l}\text { Ameaças (de Falha, de Perda } \\
\text { do Emprego, etc.) }\end{array}$ \\
\hline 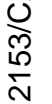 & $\begin{array}{l}\text { Fatores de Stress } \\
\text { Psicológicos }\end{array}$ & Carga Pesada de Informações \\
\hline$\frac{5}{\grave{0}}$ & $\begin{array}{l}\text { Fatores de Stress } \\
\text { Psicológicos }\end{array}$ & $\begin{array}{c}\text { Falta de Recompensas, } \\
\text { Reconhecimento e Benefícios }\end{array}$ \\
\hline 产 & $\begin{array}{l}\text { Fatores de Stress } \\
\text { Psicológicos }\end{array}$ & Início Inesperado do Stress \\
\hline 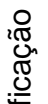 & $\begin{array}{l}\text { Fatores de Stress } \\
\text { Psicológicos }\end{array}$ & $\begin{array}{c}\text { M otivos Conflitantes sobre o } \\
\text { Desempenho no Trabalho }\end{array}$ \\
\hline 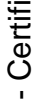 & $\begin{array}{l}\text { Fatores de Stress } \\
\text { Psicológicos }\end{array}$ & Reforço Negativo \\
\hline 高 & $\begin{array}{l}\text { Fatores de Stress } \\
\text { Psicológicos }\end{array}$ & Sugestões Inconsistentes \\
\hline & $\begin{array}{l}\text { Fatores de Stress } \\
\text { Psicológicos }\end{array}$ & $\begin{array}{c}\text { Trabalho M onótono, } \\
\text { Degradante ou Sem Sentido }\end{array}$ \\
\hline & Fatores Externos & $\begin{array}{c}\text { Ações desenvolvidas por } \\
\text { Supervisores, Colegas, } \\
\text { Representantes de Sindicatos, } \\
\text { e Pessoal de Regulamentação }\end{array}$ \\
\hline & Fatores Externos & Capacidade Crítica da Tarefa \\
\hline & Fatores Externos & $\begin{array}{c}\text { Complexidade da Tarefa (Carga } \\
\text { de Informações) }\end{array}$ \\
\hline & Fatores Externos & Comunicação \\
\hline & Fatores Externos & Cuidados e Advertências \\
\hline & Fatores Externos & Estrutura de Equipe \\
\hline & Fatores Externos & Estrutura Organizacional \\
\hline & Fatores Externos & $\begin{array}{l}\text { Feedback (Conhecimento de } \\
\text { Resultados) }\end{array}$ \\
\hline & Fatores Externos & Métodos de Trabalho \\
\hline
\end{tabular}




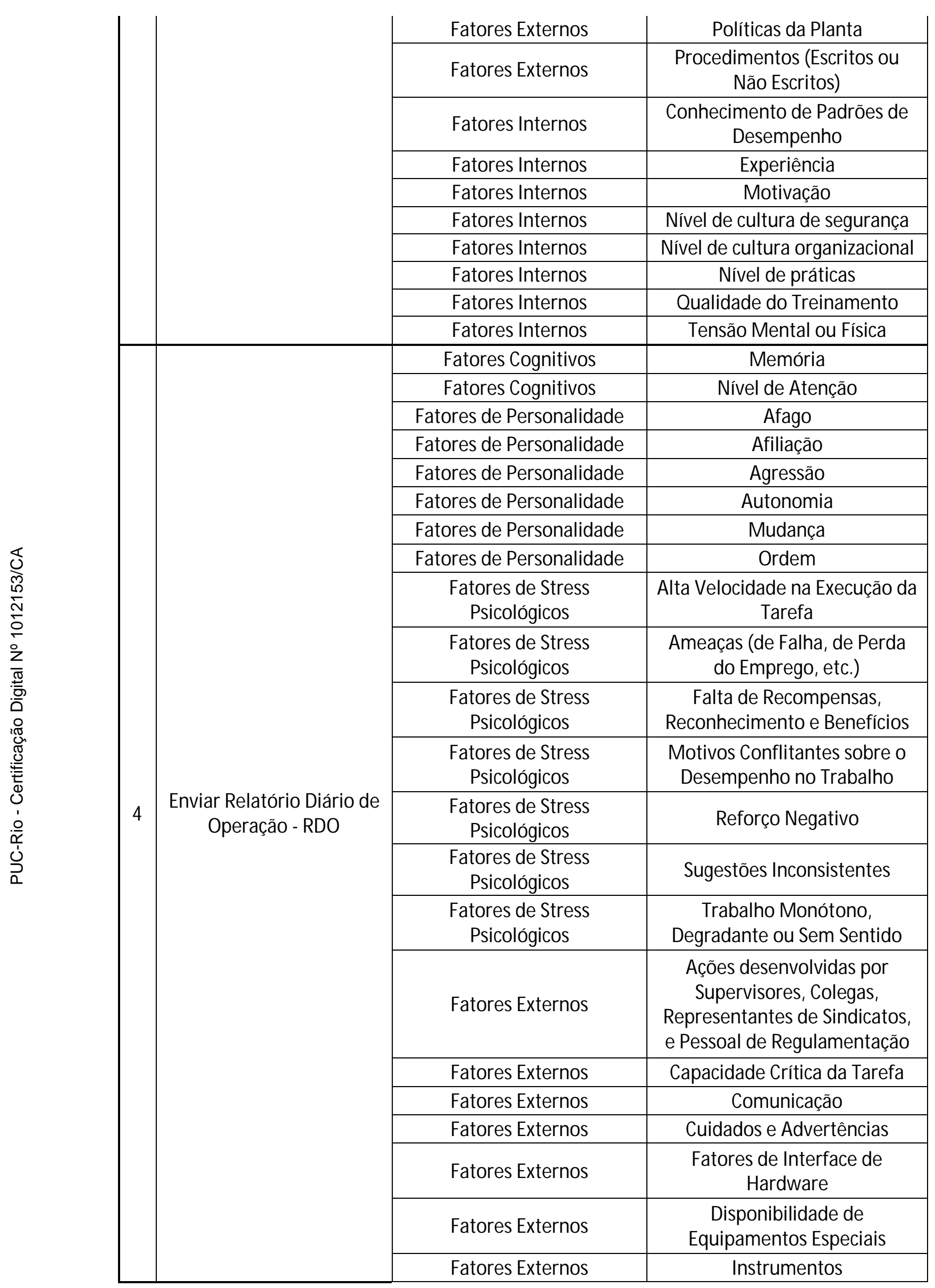




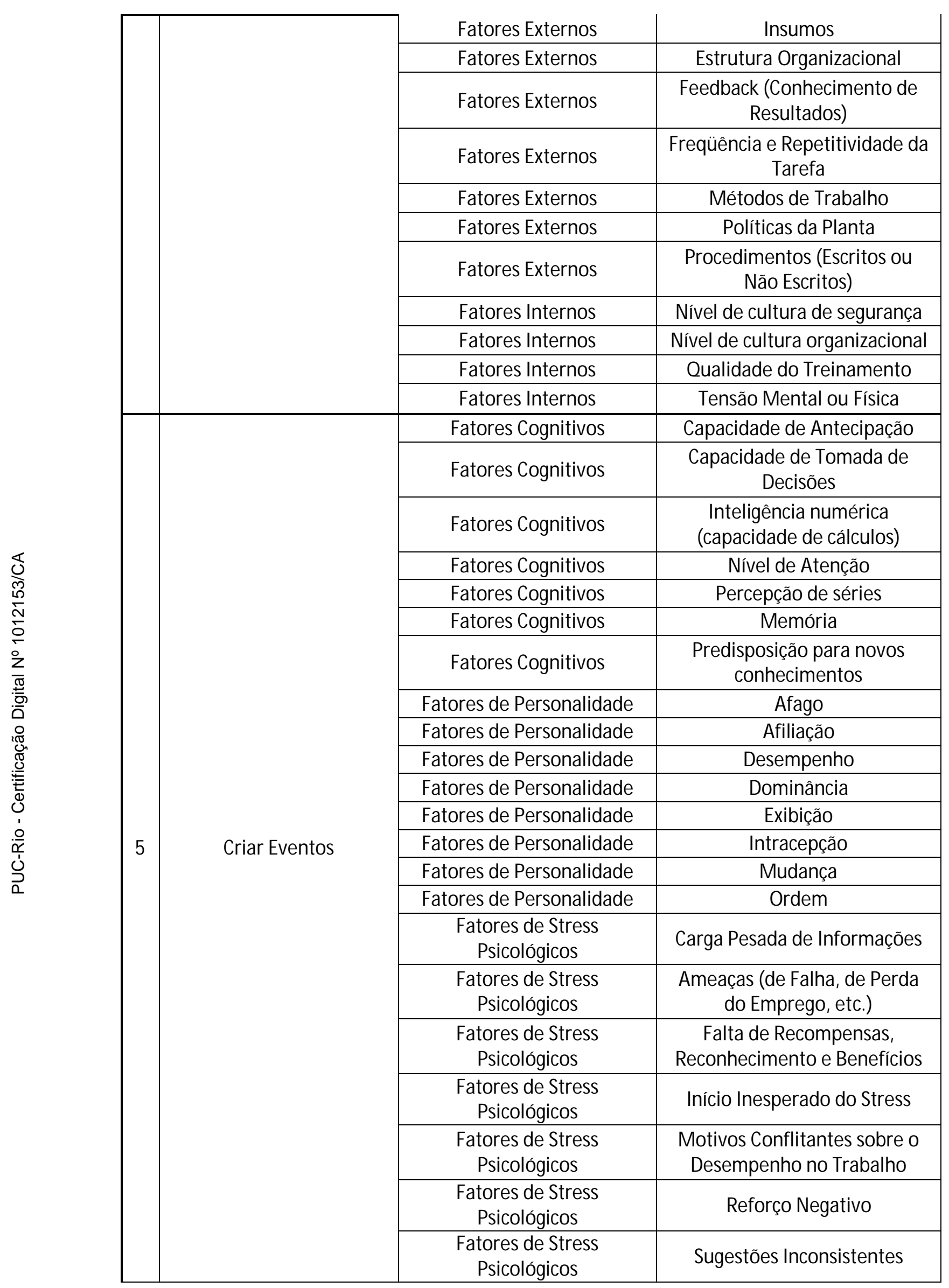




\begin{tabular}{|c|c|c|c|}
\hline & & $\begin{array}{l}\text { Fatores de Stress } \\
\text { Psicológicos }\end{array}$ & $\begin{array}{l}\text { Trabalho M onótono, } \\
\text { Degradante ou Sem Sentido }\end{array}$ \\
\hline & & Fatores Externos & $\begin{array}{l}\text { Ações desenvolvidas por } \\
\text { Supervisores, Colegas, } \\
\text { Representantes de Sindicatos, } \\
\text { e Pessoal de Regulamentação }\end{array}$ \\
\hline & & Fatores Externos & Capacidade Crítica da Tarefa \\
\hline & & Fatores Externos & $\begin{array}{c}\text { Complexidade da Tarefa (Carga } \\
\text { de Informações) }\end{array}$ \\
\hline & & Fatores Externos & Cuidados e Advertências \\
\hline & & Fatores Externos & $\begin{array}{c}\text { Disponibilidade de } \\
\text { Equipamentos Especiais }\end{array}$ \\
\hline & & Fatores Externos & Estrutura Organizacional \\
\hline & & Fatores Externos & $\begin{array}{l}\text { Feedback (Conhecimento de } \\
\text { Resultados) }\end{array}$ \\
\hline & & Fatores Externos & $\begin{array}{c}\text { Freqüência e Repetitividade da } \\
\text { Tarefa }\end{array}$ \\
\hline & & Fatores Externos & Métodos de Trabalho \\
\hline & & Fatores Externos & Políticas da Planta \\
\hline & & Fatores Externos & $\begin{array}{l}\text { Procedimentos (Escritos ou } \\
\text { Não Escritos) }\end{array}$ \\
\hline & & Fatores Externos & Motivação \\
\hline 두 & & Fatores Internos & $\begin{array}{l}\text { Conhecimento de Padrões de } \\
\text { Desempenho }\end{array}$ \\
\hline & & Fatores Internos & Experiência \\
\hline & & Fatores Internos & Nível de cultura de segurança \\
\hline 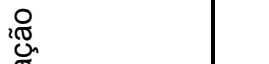 & & Fatores Internos & Nível de cultura organizacional \\
\hline & & Fatores Internos & Tensão M ental ou Física \\
\hline & \multirow{14}{*}{ Disponibilizar eventos } & Fatores Cognitivos & Capacidade de Antecipação \\
\hline ó & & Fatores Cognitivos & $\begin{array}{c}\text { Capacidade de Tomada de } \\
\text { Decisões }\end{array}$ \\
\hline & & Fatores Cognitivos & Identificação com grupos \\
\hline & & Fatores Cognitivos & Memória \\
\hline & & Fatores Cognitivos & Nível de Atenção \\
\hline & & Fatores de Personalidade & Dominância \\
\hline & & Fatores de Personalidade & Exibição \\
\hline & & Fatores de Personalidade & Intracepção \\
\hline 6 & & Fatores de Personalidade & Mudança \\
\hline & & Fatores de Personalidade & Ordem \\
\hline & & $\begin{array}{l}\text { Fatores de Stress } \\
\text { Psicológicos }\end{array}$ & $\begin{array}{c}\text { Alta Velocidade na Execução da } \\
\text { Tarefa }\end{array}$ \\
\hline & & $\begin{array}{l}\text { Fatores de Stress } \\
\text { Psicológicos }\end{array}$ & Início Inesperado do Stress \\
\hline & & $\begin{array}{l}\text { Fatores de Stress } \\
\text { Psicológicos }\end{array}$ & $\begin{array}{l}\text { M otivos Conflitantes sobre } 0 \\
\text { Desempenho no Trabalho }\end{array}$ \\
\hline & & $\begin{array}{l}\text { Fatores de Stress } \\
\text { Psicológicos }\end{array}$ & Reforço Negativo \\
\hline
\end{tabular}




\begin{tabular}{|c|c|c|c|}
\hline & & $\begin{array}{l}\text { Fatores de Stress } \\
\text { Psicológicos }\end{array}$ & Sugestões Inconsistentes \\
\hline & & $\begin{array}{l}\text { Fatores de Stress } \\
\text { Psicológicos }\end{array}$ & $\begin{array}{c}\text { Trabalho M onótono, } \\
\text { Degradante ou Sem Sentido }\end{array}$ \\
\hline & & Fatores Externos & $\begin{array}{l}\text { Ações desenvolvidas por } \\
\text { Supervisores, Colegas, } \\
\text { Representantes de Sindicatos, } \\
\text { e Pessoal de Regulamentação }\end{array}$ \\
\hline & & Fatores Externos & Capacidade Crítica da Tarefa \\
\hline & & Fatores Externos & Comunicação \\
\hline & & Fatores Externos & Cuidados e Advertências \\
\hline & & Fatores Externos & $\begin{array}{c}\text { Disponibilidade de } \\
\text { Equipamentos Especiais }\end{array}$ \\
\hline & & Fatores Externos & Estrutura de Equipe \\
\hline & & Fatores Externos & Estrutura Organizacional \\
\hline & & Fatores Externos & $\begin{array}{l}\text { Feedback (Conhecimento de } \\
\text { Resultados) }\end{array}$ \\
\hline & & Fatores Externos & $\begin{array}{c}\text { Freqüência e Repetitividade da } \\
\text { Tarefa }\end{array}$ \\
\hline & & Fatores Externos & Métodos de Trabalho \\
\hline & & Fatores Externos & Políticas da Planta \\
\hline & & Fatores Externos & $\begin{array}{l}\text { Procedimentos (Escritos ou } \\
\text { Não Escritos) }\end{array}$ \\
\hline & & Fatores Internos & Motivação \\
\hline & & Fatores Internos & Nível de cultura de segurança \\
\hline & & Fatores Internos & Nível de cultura organizacional \\
\hline & & Fatores Internos & Nível de práticas \\
\hline & & Fatores Internos & Qualidade do Treinamento \\
\hline & & Fatores Internos & Tensão M ental ou Física \\
\hline \multirow{14}{*}{7} & \multirow{14}{*}{ Substituir eventos } & Fatores Cognitivos & Capacidade de Antecipação \\
\hline & & Fatores Cognitivos & $\begin{array}{l}\text { Capacidade de Tomada de } \\
\text { Decisões }\end{array}$ \\
\hline & & Fatores Cognitivos & Memória \\
\hline & & Fatores Cognitivos & Nível de Atenção \\
\hline & & Fatores Cognitivos & Percepção de séries \\
\hline & & Fatores Cognitivos & $\begin{array}{l}\text { Predisposição para novos } \\
\text { conhecimentos }\end{array}$ \\
\hline & & Fatores de Personalidade & Afago \\
\hline & & Fatores de Personalidade & Afiliação \\
\hline & & Fatores de Personalidade & Agressão \\
\hline & & Fatores de Personalidade & Autonomia \\
\hline & & Fatores de Personalidade & Dominância \\
\hline & & Fatores de Personalidade & Mudança \\
\hline & & Fatores de Personalidade & Ordem \\
\hline & & $\begin{array}{l}\text { Fatores de Stress } \\
\text { Psicológicos }\end{array}$ & $\begin{array}{c}\text { Alta Velocidade na Execução da } \\
\text { Tarefa }\end{array}$ \\
\hline
\end{tabular}




\begin{tabular}{|c|c|c|c|}
\hline & & $\begin{array}{l}\text { Fatores de Stress } \\
\text { Psicológicos }\end{array}$ & Carga Pesada de Informações \\
\hline & & $\begin{array}{l}\text { Fatores de Stress } \\
\text { Psicológicos }\end{array}$ & Início Inesperado do Stress \\
\hline & & $\begin{array}{l}\text { Fatores de Stress } \\
\text { Psicológicos }\end{array}$ & $\begin{array}{l}\text { Motivos Conflitantes sobre o } \\
\text { Desempenho no Trabalho }\end{array}$ \\
\hline & & $\begin{array}{l}\text { Fatores de Stress } \\
\text { Psicológicos }\end{array}$ & Reforço Negativo \\
\hline & & $\begin{array}{l}\text { Fatores de Stress } \\
\text { Psicológicos }\end{array}$ & Sugestões Inconsistentes \\
\hline & & Fatores Externos & $\begin{array}{l}\text { Ações desenvolvidas por } \\
\text { Supervisores, Colegas, } \\
\text { Representantes de Sindicatos, } \\
\text { e Pessoal de Regulamentação }\end{array}$ \\
\hline & & Fatores Externos & Capacidade Crítica da Tarefa \\
\hline & & Fatores Externos & $\begin{array}{c}\text { Complexidade da Tarefa (Carga } \\
\text { de Informações) }\end{array}$ \\
\hline & & Fatores Externos & Comunicação \\
\hline & & Fatores Externos & Cuidados e Advertências \\
\hline & & Fatores Externos & $\begin{array}{c}\text { Disponibilidade de } \\
\text { Equipamentos Especiais }\end{array}$ \\
\hline & & Fatores Externos & Estrutura de Equipe \\
\hline & & Fatores Externos & Estrutura Organizacional \\
\hline 익 & & Fatores Externos & $\begin{array}{c}\text { Feedback (Conhecimento de } \\
\text { Resultados) }\end{array}$ \\
\hline 产 & & Fatores Externos & $\begin{array}{l}\text { Freqüência e Repetitividade da } \\
\text { Tarefa }\end{array}$ \\
\hline & & Fatores Externos & Métodos de Trabalho \\
\hline & & Fatores Externos & Políticas da Planta \\
\hline $\begin{array}{l}0 \\
0 \\
1\end{array}$ & & Fatores Externos & $\begin{array}{l}\text { Procedimentos (Escritos ou } \\
\text { Não Escritos) }\end{array}$ \\
\hline & & Fatores Internos & $\begin{array}{c}\text { Conhecimento de Padrões de } \\
\text { Desempenho }\end{array}$ \\
\hline & & Fatores Internos & Experiência \\
\hline & & Fatores Internos & Nível de cultura de segurança \\
\hline & & Fatores Internos & Nível de cultura organizacional \\
\hline & \multirow{9}{*}{$\begin{array}{l}\text { Criar Solicitação de } \\
\text { Serviço }\end{array}$} & Fatores Cognitivos & Capacidade de Antecipação \\
\hline & & Fatores Cognitivos & $\begin{array}{l}\text { Capacidade de Tomada de } \\
\text { Decisões }\end{array}$ \\
\hline & & Fatores Cognitivos & $\begin{array}{l}\text { Inteligência numérica } \\
\text { (capacidade de cálculos) }\end{array}$ \\
\hline 8 & & Fatores Cognitivos & Memória \\
\hline 8 & & Fatores Cognitivos & Nível de Atenção \\
\hline & & Fatores Cognitivos & Percepção de séries \\
\hline & & Fatores Cognitivos & $\begin{array}{l}\text { Predisposição para novos } \\
\text { conhecimentos }\end{array}$ \\
\hline & & Fatores de Personalidade & Afago \\
\hline & & Fatores de Personalidade & Afiliação \\
\hline
\end{tabular}




\begin{tabular}{|c|c|c|c|}
\hline & & Fatores de Personalidade & Autonomia \\
\hline & & Fatores de Personalidade & Dominância \\
\hline & & Fatores de Personalidade & Mudança \\
\hline & & Fatores de Personalidade & Ordem \\
\hline & & $\begin{array}{l}\text { Fatores de Stress } \\
\text { Psicológicos }\end{array}$ & $\begin{array}{c}\text { Alta Velocidade na Execução da } \\
\text { Tarefa }\end{array}$ \\
\hline & & $\begin{array}{l}\text { Fatores de Stress } \\
\text { Psicológicos }\end{array}$ & Carga Pesada de Informações \\
\hline & & $\begin{array}{l}\text { Fatores de Stress } \\
\text { Psicológicos }\end{array}$ & Início Inesperado do Stress \\
\hline & & $\begin{array}{l}\text { Fatores de Stress } \\
\text { Psicológicos }\end{array}$ & $\begin{array}{l}\text { M otivos Conflitantes sobre } 0 \\
\text { Desempenho no Trabalho }\end{array}$ \\
\hline & & $\begin{array}{l}\text { Fatores de Stress } \\
\text { Psicológicos }\end{array}$ & Reforço Negativo \\
\hline & & $\begin{array}{l}\text { Fatores de Stress } \\
\text { Psicológicos }\end{array}$ & Sugestões Inconsistentes \\
\hline & & $\begin{array}{l}\text { Fatores de Stress } \\
\text { Psicológicos }\end{array}$ & $\begin{array}{c}\text { Trabalho M onótono, } \\
\text { Degradante ou Sem Sentido }\end{array}$ \\
\hline 㐫 & & Fatores Externos & $\begin{array}{c}\text { Ações desenvolvidas por } \\
\text { Supervisores, Colegas, } \\
\text { Representantes de Sindicatos, } \\
\text { e Pessoal de Regulamentação }\end{array}$ \\
\hline 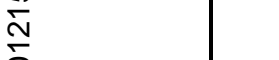 & & Fatores Externos & Capacidade Crítica da Tarefa \\
\hline$\frac{\sum_{0}^{\circ}}{\frac{1}{2}}$ & & Fatores Externos & $\begin{array}{c}\text { Complexidade da Tarefa (Carga } \\
\text { de Informações) }\end{array}$ \\
\hline 产 & & Fatores Externos & Comunicação \\
\hline 吕 & & Fatores Externos & Cuidados e Advertências \\
\hline 苋 & & Fatores Externos & $\begin{array}{c}\text { Disponibilidade de } \\
\text { Equipamentos Especiais }\end{array}$ \\
\hline$\bigcup_{1}^{0}$ & & Fatores Externos & Estrutura de Equipe \\
\hline$\frac{}{\pi}$ & & Fatores Externos & Estrutura Organizacional \\
\hline & & Fatores Externos & $\begin{array}{l}\text { Feedback (Conhecimento de } \\
\text { Resultados) }\end{array}$ \\
\hline & & Fatores Externos & $\begin{array}{l}\text { Freqüência e Repetitividade da } \\
\text { Tarefa }\end{array}$ \\
\hline & & Fatores Externos & Métodos de Trabalho \\
\hline & & Fatores Externos & Políticas da Planta \\
\hline & & Fatores Externos & $\begin{array}{l}\text { Procedimentos (Escritos ou } \\
\text { Não Escritos) }\end{array}$ \\
\hline & & Fatores Internos & $\begin{array}{c}\text { Conhecimento de Padrões de } \\
\text { Desempenho }\end{array}$ \\
\hline & & Fatores Internos & Experiência \\
\hline & & Fatores Internos & Nível de cultura de segurança \\
\hline & & Fatores Internos & Nível de cultura organizacional \\
\hline & & Fatores Internos & Tensão M ental ou Física \\
\hline 0 & Encaminhar Solicitação de & Fatores Cognitivos & Capacidade de Antecipação \\
\hline$y$ & Serviço para os & Fatores Cognitivos & Capacidade de Classificação \\
\hline
\end{tabular}




\begin{tabular}{|c|c|c|}
\hline \multirow[t]{30}{*}{ responsáveis das áreas } & Fatores Cognitivos & $\begin{array}{c}\text { Capacidade de Tomada de } \\
\text { Decisões }\end{array}$ \\
\hline & Fatores Cognitivos & Memória \\
\hline & Fatores Cognitivos & Nível de Atenção \\
\hline & Fatores de Personalidade & Autonomia \\
\hline & Fatores de Personalidade & Dominância \\
\hline & Fatores de Personalidade & Mudança \\
\hline & Fatores de Personalidade & Ordem \\
\hline & $\begin{array}{c}\text { Fatores de Stress } \\
\text { Psicológicos }\end{array}$ & $\begin{array}{c}\text { Alta Velocidade na Execução da } \\
\text { Tarefa } \\
\end{array}$ \\
\hline & $\begin{array}{l}\text { Fatores de Stress } \\
\text { Psicológicos }\end{array}$ & $\begin{array}{c}\text { Ameaças (de Falha, de Perda } \\
\text { do Emprego, etc.) }\end{array}$ \\
\hline & $\begin{array}{l}\text { Fatores de Stress } \\
\text { Psicológicos }\end{array}$ & $\begin{array}{c}\text { Falta de Recompensas, } \\
\text { Reconhecimento e Benefícios }\end{array}$ \\
\hline & $\begin{array}{l}\text { Fatores de Stress } \\
\text { Psicológicos }\end{array}$ & $\begin{array}{c}\text { Motivos Conflitantes sobre o } \\
\text { Desempenho no Trabalho }\end{array}$ \\
\hline & $\begin{array}{l}\text { Fatores de Stress } \\
\text { Psicológicos }\end{array}$ & Início Inesperado do Stress \\
\hline & $\begin{array}{l}\text { Fatores de Stress } \\
\text { Psicológicos }\end{array}$ & Reforço Negativo \\
\hline & $\begin{array}{l}\text { Fatores de Stress } \\
\text { Psicológicos }\end{array}$ & Sugestões Inconsistentes \\
\hline & $\begin{array}{l}\text { Fatores de Stress } \\
\text { Psicológicos }\end{array}$ & $\begin{array}{c}\text { Trabalho M onótono, } \\
\text { Degradante ou Sem Sentido }\end{array}$ \\
\hline & Fatores Externos & $\begin{array}{l}\text { Ações desenvolvidas por } \\
\text { Supervisores, Colegas, } \\
\text { Representantes de Sindicatos, } \\
\text { e Pessoal de Regulamentação }\end{array}$ \\
\hline & Fatores Externos & Capacidade Crítica da Tarefa \\
\hline & Fatores Externos & Comunicação \\
\hline & Fatores Externos & Cuidados e Advertências \\
\hline & Fatores Externos & $\begin{array}{c}\text { Disponibilidade de } \\
\text { Equipamentos Especiais }\end{array}$ \\
\hline & Fatores Externos & Estrutura de Equipe \\
\hline & Fatores Externos & Estrutura Organizacional \\
\hline & Fatores Externos & $\begin{array}{l}\text { Feedback (Conhecimento de } \\
\text { Resultados) }\end{array}$ \\
\hline & Fatores Externos & $\begin{array}{c}\text { Freqüência e Repetitividade da } \\
\text { Tarefa }\end{array}$ \\
\hline & Fatores Externos & Métodos de Trabalho \\
\hline & Fatores Externos & Políticas da Planta \\
\hline & Fatores Externos & $\begin{array}{c}\text { Procedimentos (Escritos ou } \\
\text { Não Escritos) }\end{array}$ \\
\hline & Fatores Externos & Rodízio de Turnos \\
\hline & Fatores Internos & Nível de cultura de segurança \\
\hline & Fatores Internos & Nível de cultura organizacional \\
\hline
\end{tabular}




\begin{tabular}{|l|l|c|}
\hline \multirow{2}{*}{} & Fatores Internos & Nível de práticas \\
\cline { 2 - 3 } & Fatores Internos & Qualidade do Treinamento \\
\cline { 2 - 3 } & Fatores Internos & Tensão M ental ou Física \\
\hline
\end{tabular}

Tabela 18: Associação de tarefas do Procedimento para Implantação de

Documentação com PSFs pertinentes

\begin{tabular}{|c|c|c|c|}
\hline \multicolumn{4}{|c|}{ Procedimento para Operação em Regime Normal } \\
\hline & Tarefas & Grupo de PSFs & PSF \\
\hline \multirow{25}{*}{1} & \multirow{25}{*}{$\begin{array}{l}\text { Supervisionar as } \\
\text { instalações de sua } \\
\text { responsabilidade }\end{array}$} & Fatores Cognitivos & Capacidade Analítica \\
\hline & & Fatores Cognitivos & $\begin{array}{c}\text { Capacidade de Tomada de } \\
\text { Decisões }\end{array}$ \\
\hline & & Fatores Cognitivos & Identificação com grupos \\
\hline & & Fatores Cognitivos & $\begin{array}{l}\text { Inteligência numérica } \\
\text { (capacidade de cálculos) }\end{array}$ \\
\hline & & Fatores Cognitivos & Memória \\
\hline & & Fatores Cognitivos & Nível de Atenção \\
\hline & & Fatores Cognitivos & Percepção de séries \\
\hline & & Fatores de Personalidade & Afago \\
\hline & & Fatores de Personalidade & Afiliação \\
\hline & & Fatores de Personalidade & Agressão \\
\hline & & Fatores de Personalidade & Assistência \\
\hline & & Fatores de Personalidade & Desempenho \\
\hline & & Fatores de Personalidade & Dominância \\
\hline & & Fatores de Personalidade & Intracepção \\
\hline & & Fatores de Personalidade & Ordem \\
\hline & & $\begin{array}{l}\text { Fatores de Stress } \\
\text { Psicológicos }\end{array}$ & Carga Pesada de Informações \\
\hline & & $\begin{array}{l}\text { Fatores de Stress } \\
\text { Psicológicos }\end{array}$ & Início Inesperado do Stress \\
\hline & & $\begin{array}{l}\text { Fatores de Stress } \\
\text { Psicológicos }\end{array}$ & $\begin{array}{l}\text { Distrações (devido a Ruído, } \\
\text { Clarão, M ovimentos, etc.) }\end{array}$ \\
\hline & & $\begin{array}{l}\text { Fatores de Stress } \\
\text { Psicológicos }\end{array}$ & $\begin{array}{c}\text { Ameaças (de Falha, de Perda } \\
\text { do Emprego, etc.) }\end{array}$ \\
\hline & & $\begin{array}{l}\text { Fatores de Stress } \\
\text { Psicológicos }\end{array}$ & $\begin{array}{c}\text { Falta de Recompensas, } \\
\text { Reconhecimento e Benefícios }\end{array}$ \\
\hline & & $\begin{array}{l}\text { Fatores de Stress } \\
\text { Psicológicos }\end{array}$ & Carga Pesada de Informações \\
\hline & & $\begin{array}{l}\text { Fatores de Stress } \\
\text { Psicológicos }\end{array}$ & Início Inesperado do Stress \\
\hline & & $\begin{array}{l}\text { Fatores de Stress } \\
\text { Psicológicos }\end{array}$ & $\begin{array}{c}\text { M otivos Conflitantes sobre o } \\
\text { Desempenho no Trabalho }\end{array}$ \\
\hline & & $\begin{array}{l}\text { Fatores de Stress } \\
\text { Psicológicos }\end{array}$ & $\begin{array}{c}\text { Períodos de Vigilância Longos, } \\
\text { sem Acontecimentos }\end{array}$ \\
\hline & & $\begin{array}{l}\text { Fatores de Stress } \\
\text { Psicológicos }\end{array}$ & $\begin{array}{c}\text { Trabalho M onótono, } \\
\text { Degradante ou Sem Sentido }\end{array}$ \\
\hline
\end{tabular}




\begin{tabular}{|c|c|c|c|}
\hline & & Fatores Externos & $\begin{array}{c}\text { Ações desenvolvidas por } \\
\text { Supervisores, Colegas, } \\
\text { Representantes de Sindicatos, } \\
\text { e Pessoal de Regulamentação }\end{array}$ \\
\hline & & Fatores Externos & Capacidade Crítica da Tarefa \\
\hline & & Fatores Externos & $\begin{array}{c}\text { Complexidade da Tarefa (Carga } \\
\text { de Informações) }\end{array}$ \\
\hline & & Fatores Externos & Comunicação \\
\hline & & Fatores Externos & Cuidados e Advertências \\
\hline & & Fatores Externos & Estrutura de Equipe \\
\hline & & Fatores Externos & Estrutura Organizacional \\
\hline & & Fatores Externos & Métodos de Trabalho \\
\hline & & Fatores Externos & Políticas da Planta \\
\hline & & Fatores Externos & $\begin{array}{l}\text { Feedback (Conhecimento de } \\
\text { Resultados) }\end{array}$ \\
\hline & & Fatores Externos & $\begin{array}{l}\text { Procedimentos (Escritos ou } \\
\text { Não Escritos) }\end{array}$ \\
\hline & & Fatores Externos & Qualidade do Ambiente \\
\hline & & Fatores Externos & Quantidade de Pessoal \\
\hline$\frac{\widehat{\bigcup}}{\text { O্ }}$ & & Fatores Internos & $\begin{array}{c}\text { Conhecimento de Padrões de } \\
\text { Desempenho }\end{array}$ \\
\hline & & Fatores Internos & Experiência \\
\hline & & Fatores Internos & Nível de cultura de segurança \\
\hline$\frac{\pi}{\pi}$ & & Fatores Internos & Nível de cultura organizacional \\
\hline & & Fatores Internos & Nível de práticas \\
\hline$\circ$ & & Fatores Internos & Qualidade do Treinamento \\
\hline & & Fatores Internos & Tensão M ental ou Física \\
\hline & \multirow{13}{*}{$\begin{array}{l}\text { Efetuar testes de } \\
\text { funcionamento nos } \\
\text { equipamentos de } \\
\text { comunicação }\end{array}$} & Fatores Cognitivos & Capacidade Analítica \\
\hline & & Fatores Cognitivos & Capacidade de Classificação \\
\hline 产 & & Fatores Cognitivos & Memória \\
\hline & & Fatores Cognitivos & Nível de Atenção \\
\hline & & Fatores Cognitivos & Percepção de séries \\
\hline & & Fatores de Personalidade & Afago \\
\hline & & Fatores de Personalidade & Ordem \\
\hline & & $\begin{array}{l}\text { Fatores de Stress } \\
\text { Psicológicos }\end{array}$ & $\begin{array}{c}\text { Ameaças (de Falha, de Perda } \\
\text { do Emprego, etc.) }\end{array}$ \\
\hline 2 & & $\begin{array}{l}\text { Fatores de Stress } \\
\text { Psicológicos }\end{array}$ & Carga Pesada de Informações \\
\hline & & $\begin{array}{l}\text { Fatores de Stress } \\
\text { Psicológicos }\end{array}$ & $\begin{array}{l}\text { Distrações (devido a Ruído, } \\
\text { Clarão, M ovimentos, etc.) }\end{array}$ \\
\hline & & $\begin{array}{l}\text { Fatores de Stress } \\
\text { Psicológicos }\end{array}$ & $\begin{array}{c}\text { Falta de Recompensas, } \\
\text { Reconhecimento e Benefícios }\end{array}$ \\
\hline & & $\begin{array}{l}\text { Fatores de Stress } \\
\text { Psicológicos }\end{array}$ & Início Inesperado do Stress \\
\hline & & $\begin{array}{l}\text { Fatores de Stress } \\
\text { Psicológicos }\end{array}$ & $\begin{array}{l}\text { M otivos Conflitantes sobre o } \\
\text { Desempenho no Trabalho }\end{array}$ \\
\hline
\end{tabular}




\begin{tabular}{|c|c|c|c|}
\hline & & $\begin{array}{l}\text { Fatores de Stress } \\
\text { Psicológicos }\end{array}$ & Perda de Sensibilidade \\
\hline & & $\begin{array}{l}\text { Fatores de Stress } \\
\text { Psicológicos }\end{array}$ & Reforço Negativo \\
\hline & & $\begin{array}{l}\text { Fatores de Stress } \\
\text { Psicológicos }\end{array}$ & Sugestões Inconsistentes \\
\hline & & $\begin{array}{l}\text { Fatores de Stress } \\
\text { Psicológicos }\end{array}$ & $\begin{array}{c}\text { Trabalho M onótono, } \\
\text { Degradante ou Sem Sentido }\end{array}$ \\
\hline & & Fatores Externos & $\begin{array}{c}\text { Ações desenvolvidas por } \\
\text { Supervisores, Colegas, } \\
\text { Representantes de Sindicatos, } \\
\text { e Pessoal de Regulamentação }\end{array}$ \\
\hline & & Fatores Externos & Capacidade Crítica da Tarefa \\
\hline & & Fatores Externos & $\begin{array}{c}\text { Complexidade da Tarefa (Carga } \\
\text { de Informações) }\end{array}$ \\
\hline & & Fatores Externos & Comunicação \\
\hline & & Fatores Externos & $\begin{array}{c}\text { Disponibilidade de } \\
\text { Equipamentos Especiais }\end{array}$ \\
\hline & & Fatores Externos & Estrutura de Equipe \\
\hline & & Fatores Externos & Estrutura Organizacional \\
\hline 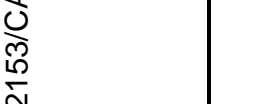 & & Fatores Externos & $\begin{array}{c}\text { Fatores de Interface de } \\
\text { Hardware }\end{array}$ \\
\hline $\begin{array}{l}\frac{1}{5} \\
\frac{1}{0} \\
\text { ol } \\
Z\end{array}$ & & Fatores Externos & $\begin{array}{l}\text { Feedback (Conhecimento de } \\
\text { Resultados) }\end{array}$ \\
\hline : & & Fatores Externos & $\begin{array}{c}\text { Freqüência e Repetitividade da } \\
\text { Tarefa }\end{array}$ \\
\hline 胥 & & Fatores Externos & $\begin{array}{c}\text { Horas de Trabalho / Intervalos } \\
\text { de Trabalho }\end{array}$ \\
\hline & & Fatores Externos & Instrumentos \\
\hline & & Fatores Externos & Insumos \\
\hline & & Fatores Externos & M étodos de Trabalho \\
\hline & & Fatores Externos & Políticas da Planta \\
\hline & & Fatores Externos & $\begin{array}{l}\text { Procedimentos (Escritos ou } \\
\text { Não Escritos) }\end{array}$ \\
\hline & & Fatores Externos & Qualidade do Ambiente \\
\hline & & Fatores Internos & $\begin{array}{l}\text { Conhecimento de Padrões de } \\
\text { Desempenho }\end{array}$ \\
\hline & & Fatores Internos & Experiência \\
\hline & & Fatores Internos & Nível de cultura de segurança \\
\hline & & Fatores Internos & Nível de cultura organizacional \\
\hline & & Fatores Internos & Nível de práticas \\
\hline & & Fatores Internos & Qualidade do Treinamento \\
\hline & & Fatores Internos & Tensão M ental ou Física \\
\hline 3 & Executar manobras nos & Fatores Cognitivos & Capacidade Analítica \\
\hline 3 & equipamentos das & Fatores Cognitivos & Capacidade de Classificação \\
\hline
\end{tabular}


subestações de sua responsabilidade sempre que necessário (controle de tensão)

\begin{tabular}{|c|c|}
\hline Fatores Cognitivos & $\begin{array}{c}\text { Capacidade de Tomada de } \\
\text { Decisões }\end{array}$ \\
\hline Fatores Cognitivos & Memória \\
\hline Fatores Cognitivos & Nível de Atenção \\
\hline Fatores de Personalidade & Afiliação \\
\hline Fatores de Personalidade & Afago \\
\hline Fatores de Personalidade & Ordem \\
\hline Fatores de Personalidade & Persistência \\
\hline $\begin{array}{c}\text { Fatores de Stress } \\
\text { Fisiológicos }\end{array}$ & Constrição de M ovimentos \\
\hline $\begin{array}{l}\text { Fatores de Stress } \\
\text { Fisiológicos }\end{array}$ & Dor ou Desconforto \\
\hline $\begin{array}{l}\text { Fatores de Stress } \\
\text { Fisiológicos }\end{array}$ & Exercício Físico \\
\hline $\begin{array}{l}\text { Fatores de Stress } \\
\text { Fisiológicos }\end{array}$ & Fadiga \\
\hline $\begin{array}{l}\text { Fatores de Stress } \\
\text { Fisiológicos }\end{array}$ & Fome ou Sede \\
\hline $\begin{array}{l}\text { Fatores de Stress } \\
\text { Fisiológicos }\end{array}$ & $\begin{array}{l}\text { Interrupção do Ritmo } \\
\text { Circadiano }\end{array}$ \\
\hline $\begin{array}{c}\text { Fatores de Stress } \\
\text { Fisiológicos }\end{array}$ & Longa Duração do Stress \\
\hline $\begin{array}{l}\text { Fatores de Stress } \\
\text { Fisiológicos }\end{array}$ & Repetição de M ovimentos \\
\hline $\begin{array}{l}\text { Fatores de Stress } \\
\text { Fisiológicos }\end{array}$ & Trabalho em Alturas \\
\hline $\begin{array}{l}\text { Fatores de Stress } \\
\text { Psicológicos }\end{array}$ & $\begin{array}{l}\text { Alta Velocidade na Execução da } \\
\text { Tarefa }\end{array}$ \\
\hline $\begin{array}{l}\text { Fatores de Stress } \\
\text { Psicológicos }\end{array}$ & $\begin{array}{c}\text { Ameaças (de Falha, de Perda } \\
\text { do Emprego, etc.) }\end{array}$ \\
\hline $\begin{array}{l}\text { Fatores de Stress } \\
\text { Psicológicos }\end{array}$ & Carga Pesada de Informações \\
\hline $\begin{array}{l}\text { Fatores de Stress } \\
\text { Psicológicos }\end{array}$ & $\begin{array}{l}\text { Distrações (devido a Ruído, } \\
\text { Clarão, M ovimentos, etc.) }\end{array}$ \\
\hline $\begin{array}{l}\text { Fatores de Stress } \\
\text { Psicológicos }\end{array}$ & $\begin{array}{c}\text { Falta de Recompensas, } \\
\text { Reconhecimento e Benefícios }\end{array}$ \\
\hline $\begin{array}{l}\text { Fatores de Stress } \\
\text { Psicológicos }\end{array}$ & Início Inesperado do Stress \\
\hline $\begin{array}{c}\text { Fatores de Stress } \\
\text { Psicológicos }\end{array}$ & $\begin{array}{c}\text { M otivos Conflitantes sobre o } \\
\text { Desempenho no Trabalho }\end{array}$ \\
\hline $\begin{array}{l}\text { Fatores de Stress } \\
\text { Psicológicos }\end{array}$ & Perda de Sensibilidade \\
\hline $\begin{array}{l}\text { Fatores de Stress } \\
\text { Psicológicos }\end{array}$ & Reforço Negativo \\
\hline $\begin{array}{l}\text { Fatores de Stress } \\
\text { Psicológicos }\end{array}$ & Sugestões Inconsistentes \\
\hline $\begin{array}{l}\text { Fatores de Stress } \\
\text { Psicológicos }\end{array}$ & $\begin{array}{c}\text { Trabalho M onótono, } \\
\text { Degradante ou Sem Sentido }\end{array}$ \\
\hline
\end{tabular}




\begin{tabular}{|c|c|c|c|}
\hline & & Fatores Externos & $\begin{array}{l}\text { Ações desenvolvidas por } \\
\text { Supervisores, Colegas, } \\
\text { Representantes de Sindicatos, } \\
\text { e Pessoal de Regulamentação }\end{array}$ \\
\hline & & Fatores Externos & Capacidade Crítica da Tarefa \\
\hline & & Fatores Externos & $\begin{array}{c}\text { Complexidade da Tarefa (Carga } \\
\text { de Informações) }\end{array}$ \\
\hline & & Fatores Externos & Cuidados e Advertências \\
\hline & & Fatores Externos & $\begin{array}{c}\text { Disponibilidade de } \\
\text { Equipamentos Especiais }\end{array}$ \\
\hline & & Fatores Externos & $\begin{array}{c}\text { Fatores de Interface de } \\
\text { Hardware }\end{array}$ \\
\hline & & Fatores Externos & $\begin{array}{l}\text { Freqüência e Repetitividade da } \\
\text { Tarefa }\end{array}$ \\
\hline & & Fatores Externos & Instrumentos \\
\hline & & Fatores Externos & Insumos \\
\hline & & Fatores Externos & $\begin{array}{l}\text { Feedback (Conhecimento de } \\
\text { Resultados) }\end{array}$ \\
\hline & & Fatores Externos & $\begin{array}{c}\text { Procedimentos (Escritos ou } \\
\text { Não Escritos) }\end{array}$ \\
\hline 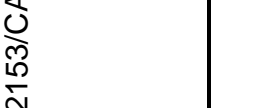 & & Fatores Internos & $\begin{array}{l}\text { Conhecimento de Padrões de } \\
\text { Desempenho }\end{array}$ \\
\hline & & Fatores Internos & Experiência \\
\hline 高 & & Fatores Internos & Tensão M ental ou Física \\
\hline$\overline{\bar{\sigma}}$ & & Fatores Internos & Motivação \\
\hline & & Fatores Internos & Nível de cultura de segurança \\
\hline ৪ & & Fatores Internos & Nível de cultura organizacional \\
\hline & & Fatores Internos & Nível de práticas \\
\hline 吾 & & Fatores Internos & Qualidade do Treinamento \\
\hline & & Fatores Cognitivos & Capacidade Analítica \\
\hline & & Fatores Cognitivos & $\begin{array}{c}\text { Capacidade de Tomada de } \\
\text { Decisões }\end{array}$ \\
\hline & & Fatores Cognitivos & Identificação com grupos \\
\hline & & Fatores Cognitivos & $\begin{array}{l}\text { Inteligência numérica } \\
\text { (capacidade de cálculos) }\end{array}$ \\
\hline & Delegar ao operador - & Fatores Cognitivos & Nível de Atenção \\
\hline 4 & mantenedor de uma & Fatores Cognitivos & $\begin{array}{l}\text { Inteligência numérica } \\
\text { (capacidade de cálculos) }\end{array}$ \\
\hline & execucão de manobras & Fatores Cognitivos & Percepção de séries \\
\hline & sempre que necessário & Fatores de Personalidade & Afago \\
\hline & & Fatores de Personalidade & Afiliação \\
\hline & & Fatores de Personalidade & Autonomia \\
\hline & & Fatores de Personalidade & Desempenho \\
\hline & & Fatores de Personalidade & Dominância \\
\hline & & Fatores de Personalidade & Ordem \\
\hline & & Fatores de Personalidade & Persistência \\
\hline
\end{tabular}




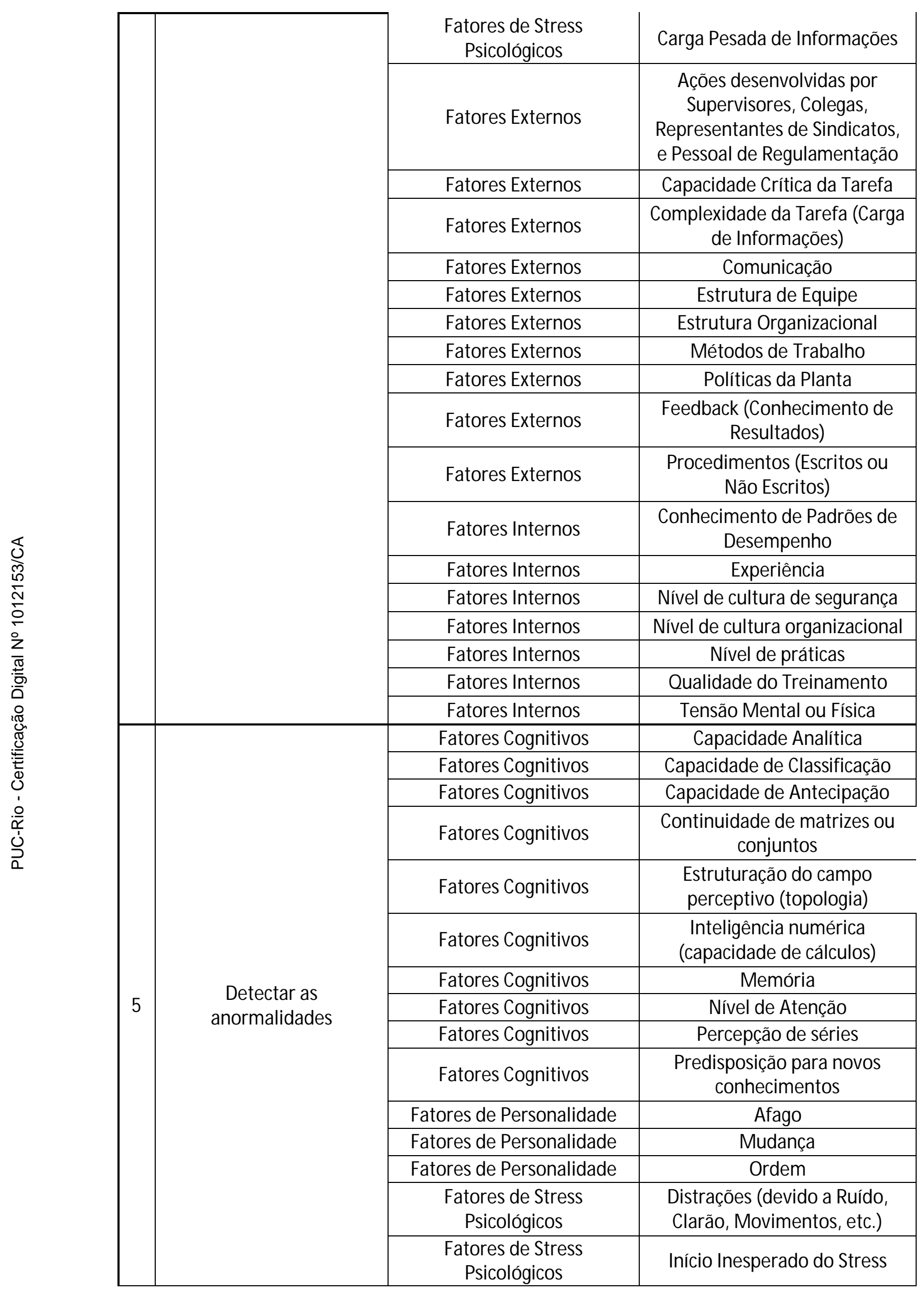




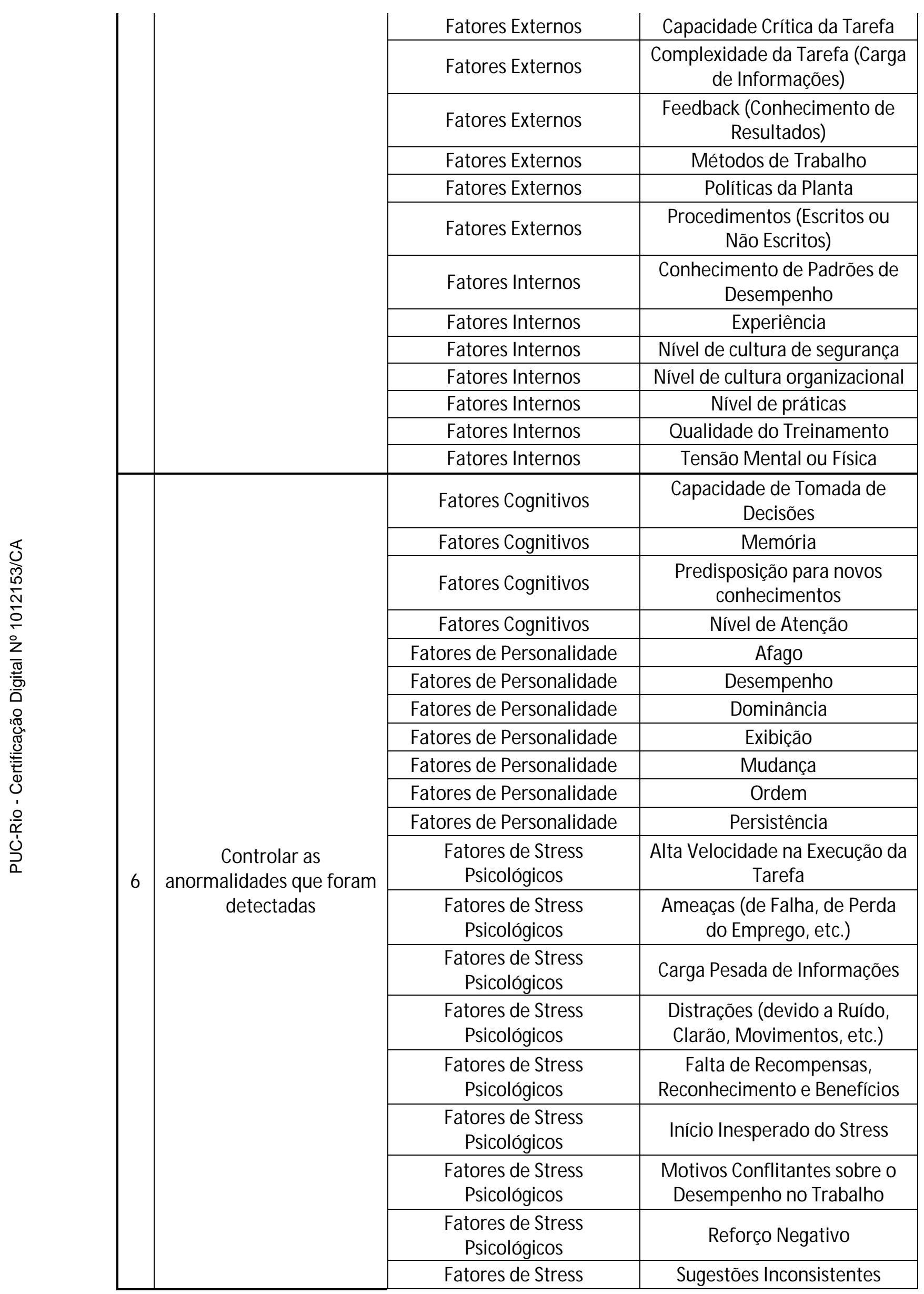




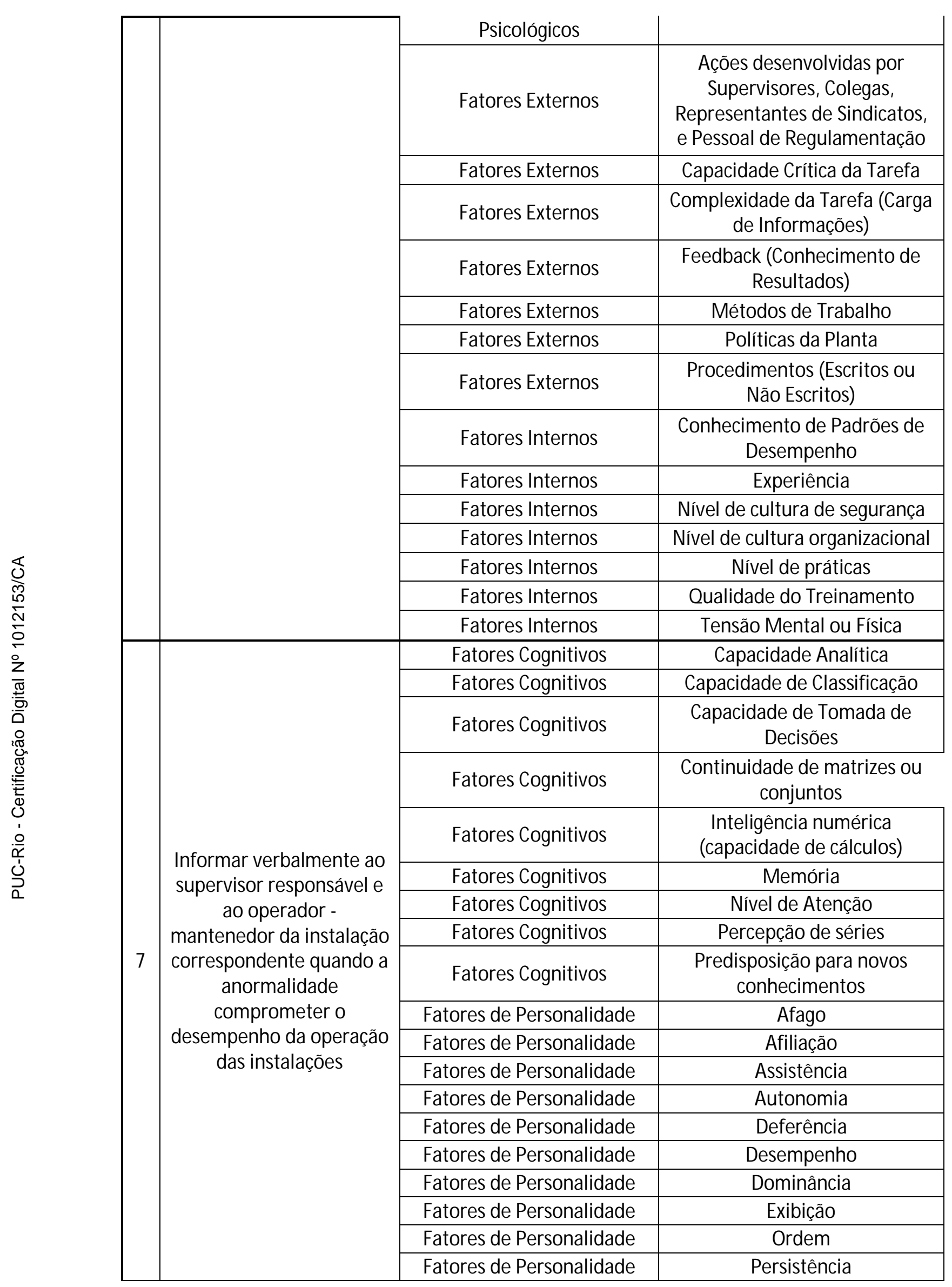




\begin{tabular}{|c|c|c|c|}
\hline & & $\begin{array}{l}\text { Fatores de Stress } \\
\text { Psicológicos }\end{array}$ & $\begin{array}{l}\text { Alta Velocidade na Execução da } \\
\text { Tarefa }\end{array}$ \\
\hline & & $\begin{array}{l}\text { Fatores de Stress } \\
\text { Psicológicos }\end{array}$ & Carga Pesada de Informações \\
\hline & & $\begin{array}{l}\text { Fatores de Stress } \\
\text { Psicológicos }\end{array}$ & Início Inesperado do Stress \\
\hline & & $\begin{array}{l}\text { Fatores de Stress } \\
\text { Psicológicos }\end{array}$ & $\begin{array}{l}\text { Motivos Conflitantes sobre } 0 \\
\text { Desempenho no Trabalho }\end{array}$ \\
\hline & & Fatores Externos & $\begin{array}{l}\text { Ações desenvolvidas por } \\
\text { Supervisores, Colegas, } \\
\text { Representantes de Sindicatos, } \\
\text { e Pessoal de Regulamentação }\end{array}$ \\
\hline & & Fatores Externos & Comunicação \\
\hline & & Fatores Externos & Estrutura de Equipe \\
\hline & & Fatores Externos & Estrutura Organizacional \\
\hline & & Fatores Externos & Métodos de Trabalho \\
\hline & & Fatores Externos & Políticas da Planta \\
\hline & & Fatores Externos & $\begin{array}{l}\text { Feedback (Conhecimento de } \\
\text { Resultados) }\end{array}$ \\
\hline & & Fatores Externos & $\begin{array}{l}\text { Procedimentos (Escritos ou } \\
\text { Não Escritos) }\end{array}$ \\
\hline 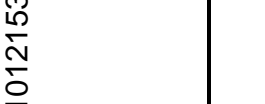 & & Fatores Internos & $\begin{array}{l}\text { Conhecimento de Padrões de } \\
\text { Desempenho }\end{array}$ \\
\hline ò & & Fatores Internos & Experiência \\
\hline$\frac{\bar{\sigma}}{\sigma}$ & & Fatores Internos & Nível de cultura de segurança \\
\hline & & Fatores Internos & Nível de cultura organizacional \\
\hline i্ & & Fatores Internos & Nível de práticas \\
\hline & & Fatores Internos & Qualidade do Treinamento \\
\hline & & Fatores Internos & Tensão M ental ou Física \\
\hline & & Fatores Cognitivos & Capacidade de Antecipação \\
\hline & & Fatores Cognitivos & Identificação com grupos \\
\hline & & Fatores Cognitivos & Nível de Atenção \\
\hline & & Fatores Cognitivos & Percepção de séries \\
\hline & & Fatores de Personalidade & Afago \\
\hline & & Fatores de Personalidade & Afiliação \\
\hline & & Fatores de Personalidade & Desempenho \\
\hline & & Fatores de Personalidade & Dominância \\
\hline 8 & Realizar transferência de & Fatores de Personalidade & Ordem \\
\hline & & Fatores de Personalidade & Persistência \\
\hline & & $\begin{array}{l}\text { Fatores de Stress } \\
\text { Psicológicos }\end{array}$ & $\begin{array}{c}\text { Alta Velocidade na Execução da } \\
\text { Tarefa }\end{array}$ \\
\hline & & $\begin{array}{l}\text { Fatores de Stress } \\
\text { Psicológicos }\end{array}$ & $\begin{array}{l}\text { Distrações (devido a Ruído, } \\
\text { Clarão, M ovimentos, etc.) }\end{array}$ \\
\hline & & Fatores Externos & $\begin{array}{c}\text { Ações desenvolvidas por } \\
\text { Supervisores, Colegas, } \\
\text { Representantes de Sindicatos, } \\
\text { e Pessoal de Regulamentação }\end{array}$ \\
\hline
\end{tabular}




\begin{tabular}{|c|c|}
\hline Fatores Externos & Comunicação \\
\hline Fatores Externos & Estrutura de Equipe \\
\hline Fatores Externos & Estrutura Organizacional \\
\hline Fatores Externos & $\begin{array}{c}\text { Horas de Trabalho / Intervalos } \\
\text { de Trabalho }\end{array}$ \\
\hline Fatores Externos & Políticas da Planta \\
\hline Fatores Externos & $\begin{array}{l}\text { Procedimentos (Escritos ou } \\
\text { Não Escritos) }\end{array}$ \\
\hline Fatores Externos & Quantidade de Pessoal \\
\hline Fatores Externos & Rodízio de Turnos \\
\hline Fatores Internos & Condição Física/Saúde \\
\hline Fatores Internos & $\begin{array}{c}\text { Conhecimento de Padrões de } \\
\text { Desempenho }\end{array}$ \\
\hline Fatores Internos & Experiência \\
\hline Fatores Internos & $\begin{array}{l}\text { Influência de outros agentes } \\
\text { externos (pessoas, família) }\end{array}$ \\
\hline Fatores Internos & Nível de cultura de segurança \\
\hline Fatores Internos & Nível de cultura organizacional \\
\hline Fatores Internos & Nível de práticas \\
\hline Fatores Internos & Qualidade do Treinamento \\
\hline Fatores Internos & Tensão M ental ou Física \\
\hline
\end{tabular}

Tabela 19: Associação de tarefas do Procedimento para Operação em Regime

Normal com PSFs pertinentes

\begin{tabular}{|c|c|c|c|}
\hline \multicolumn{4}{|c|}{ Procedimento para Programação de Intervenção em Urgência ou Emergência } \\
\hline & Tarefas & Grupo de PSFs & PSF \\
\hline \multirow{13}{*}{1} & \multirow{13}{*}{$\begin{array}{l}\text { Receber Solicitação de } \\
\text { Intervenção }\end{array}$} & Fatores Cognitivos & Nível de Atenção \\
\hline & & Fatores de Personalidade & Afago \\
\hline & & Fatores de Personalidade & Afiliação \\
\hline & & Fatores de Personalidade & Autonomia \\
\hline & & Fatores de Personalidade & Mudança \\
\hline & & Fatores de Personalidade & Ordem \\
\hline & & Fatores de Personalidade & Persistência \\
\hline & & $\begin{array}{l}\text { Fatores de Stress } \\
\text { Psicológicos }\end{array}$ & $\begin{array}{c}\text { Alta Velocidade na Execução } \\
\text { da Tarefa }\end{array}$ \\
\hline & & $\begin{array}{l}\text { Fatores de Stress } \\
\text { Psicológicos }\end{array}$ & Carga Pesada de Informações \\
\hline & & $\begin{array}{l}\text { Fatores de Stress } \\
\text { Psicológicos }\end{array}$ & $\begin{array}{l}\text { Distrações (devido a Ruído, } \\
\text { Clarão, M ovimentos, etc.) }\end{array}$ \\
\hline & & $\begin{array}{l}\text { Fatores de Stress } \\
\text { Psicológicos }\end{array}$ & $\begin{array}{c}\text { Falta de Recompensas, } \\
\text { Reconhecimento e Benefícios }\end{array}$ \\
\hline & & $\begin{array}{l}\text { Fatores de Stress } \\
\text { Psicológicos }\end{array}$ & Início Inesperado do Stress \\
\hline & & $\begin{array}{l}\text { Fatores de Stress } \\
\text { Psicológicos }\end{array}$ & $\begin{array}{c}\text { Motivos Conflitantes sobre } 0 \\
\text { Desempenho no Trabalho }\end{array}$ \\
\hline
\end{tabular}




\begin{tabular}{|c|c|c|c|}
\hline & & $\begin{array}{l}\text { Fatores de Stress } \\
\text { Psicológicos }\end{array}$ & Sugestões Inconsistentes \\
\hline & & Fatores Externos & $\begin{array}{c}\text { Ações desenvolvidas por } \\
\text { Supervisores, Colegas, } \\
\text { Representantes de Sindicatos, } \\
\text { e Pessoal de Regulamentação }\end{array}$ \\
\hline & & Fatores Externos & Capacidade Crítica da Tarefa \\
\hline & & Fatores Externos & $\begin{array}{c}\text { Complexidade da Tarefa (Carga } \\
\text { de Informações) }\end{array}$ \\
\hline & & Fatores Externos & Comunicação \\
\hline & & Fatores Externos & Cuidados e Advertências \\
\hline & & Fatores Externos & $\begin{array}{c}\text { Feedback (Conhecimento de } \\
\text { Resultados) }\end{array}$ \\
\hline & & Fatores Externos & $\begin{array}{c}\text { Freqüência e Repetitividade da } \\
\text { Tarefa }\end{array}$ \\
\hline & & Fatores Externos & $\begin{array}{c}\text { Horas de Trabalho / Intervalos } \\
\text { de Trabalho }\end{array}$ \\
\hline & & Fatores Externos & Métodos de Trabalho \\
\hline & & Fatores Externos & Políticas da Planta \\
\hline ঠ્ల & & Fatores Externos & $\begin{array}{c}\text { Procedimentos (Escritos ou } \\
\text { Não Escritos) }\end{array}$ \\
\hline$\stackrel{\stackrel{N}{N}}{\stackrel{N}{\tau}}$ & & Fatores Externos & Quantidade de Pessoal \\
\hline 0 & & Fatores Externos & Rodízio de Turnos \\
\hline$\frac{2}{2}$ & & Fatores Internos & $\begin{array}{c}\text { Conhecimento de Padrões de } \\
\text { Desempenho }\end{array}$ \\
\hline $\begin{array}{ll}0 \\
2 \\
2 \\
2\end{array}$ & & Fatores Internos & Experiência \\
\hline שֶ๊ & & Fatores Internos & Nível de cultura de segurança \\
\hline & & Fatores Internos & Nível de cultura organizacional \\
\hline$\stackrel{0}{0}$ & & Fatores Internos & Nível de práticas \\
\hline$\frac{\circ}{\sim}$ & & Fatores Internos & Qualidade do Treinamento \\
\hline 仓่ & & Fatores Internos & Tensão Mental ou Física \\
\hline & & Fatores Cognitivos & Memória \\
\hline & & Fatores Cognitivos & Nível de Atenção \\
\hline & & Fatores de Personalidade & Afago \\
\hline & & Fatores de Personalidade & Agressão \\
\hline & & Fatores de Personalidade & Autonomia \\
\hline & & Fatores de Personalidade & Ordem \\
\hline 2 & Cadastrar intervenção no & $\begin{array}{l}\text { Fatores de Stress } \\
\text { Psicológicos }\end{array}$ & Carga Pesada de Informações \\
\hline & aplicativo SGI do ONS & $\begin{array}{l}\text { Fatores de Stress } \\
\text { Psicológicos }\end{array}$ & Início Inesperado do Stress \\
\hline & & $\begin{array}{l}\text { Fatores de Stress } \\
\text { Psicológicos }\end{array}$ & Reforço Negativo \\
\hline & & $\begin{array}{l}\text { Fatores de Stress } \\
\text { Psicológicos }\end{array}$ & Sugestões Inconsistentes \\
\hline & & $\begin{array}{l}\text { Fatores de Stress } \\
\text { Psicológicos }\end{array}$ & $\begin{array}{c}\text { Trabalho M onótono, } \\
\text { Degradante ou Sem Sentido }\end{array}$ \\
\hline
\end{tabular}




\begin{tabular}{|c|c|c|c|}
\hline & & Fatores Externos & $\begin{array}{l}\text { Ações desenvolvidas por } \\
\text { Supervisores, Colegas, } \\
\text { Representantes de Sindicatos, } \\
\text { e Pessoal de Regulamentação }\end{array}$ \\
\hline & & Fatores Externos & Capacidade Crítica da Tarefa \\
\hline & & Fatores Externos & $\begin{array}{c}\text { Complexidade da Tarefa (Carga } \\
\text { de Informações) }\end{array}$ \\
\hline & & Fatores Externos & Comunicação \\
\hline & & Fatores Externos & Cuidados e Advertências \\
\hline & & Fatores Externos & $\begin{array}{c}\text { Disponibilidade de } \\
\text { Equipamentos Especiais }\end{array}$ \\
\hline & & Fatores Externos & Estrutura de Equipe \\
\hline & & Fatores Externos & Estrutura Organizacional \\
\hline & & Fatores Externos & $\begin{array}{c}\text { Fatores de Interface de } \\
\text { Hardware }\end{array}$ \\
\hline & & Fatores Externos & Instrumentos \\
\hline & & Fatores Externos & Insumos \\
\hline & & Fatores Externos & Métodos de Trabalho \\
\hline & & Fatores Externos & Políticas da Planta \\
\hline & & Fatores Externos & $\begin{array}{l}\text { Procedimentos (Escritos ou } \\
\text { Não Escritos) }\end{array}$ \\
\hline $\bar{N}$ & & Fatores Internos & $\begin{array}{c}\text { Conhecimento de Padrões de } \\
\text { Desempenho }\end{array}$ \\
\hline & & Fatores Internos & Experiência \\
\hline & & Fatores Internos & Nível de cultura de segurança \\
\hline & & Fatores Internos & Nível de cultura organizacional \\
\hline & & Fatores Internos & Nível de práticas \\
\hline & & Fatores Internos & Qualidade do Treinamento \\
\hline & & Fatores Internos & Tensão Mental ou Física \\
\hline 윽 & \multirow{13}{*}{$\begin{array}{c}\text { Realizar contato com o } \\
\text { Centro de Operação do } \\
\text { ONS correspondente para } \\
\text { obter aprovação da } \\
\text { intervenção cadastrada }\end{array}$} & Fatores Cognitivos & Capacidade de Antecipação \\
\hline & & Fatores Cognitivos & Memória \\
\hline & & Fatores Cognitivos & Nível de Atenção \\
\hline & & Fatores de Personalidade & Afago \\
\hline & & Fatores de Personalidade & Afiliação \\
\hline & & Fatores de Personalidade & Agressão \\
\hline & & Fatores de Personalidade & Autonomia \\
\hline & & Fatores de Personalidade & Ordem \\
\hline 3 & & $\begin{array}{l}\text { Fatores de Stress } \\
\text { Psicológicos }\end{array}$ & Carga Pesada de Informações \\
\hline & & $\begin{array}{l}\text { Fatores de Stress } \\
\text { Psicológicos }\end{array}$ & $\begin{array}{l}\text { Distrações (devido a Ruído, } \\
\text { Clarão, M ovimentos, etc.) }\end{array}$ \\
\hline & & $\begin{array}{c}\text { Fatores de Stress } \\
\text { Psicológicos }\end{array}$ & Início Inesperado do Stress \\
\hline & & $\begin{array}{c}\text { Fatores de Stress } \\
\text { Psicológicos }\end{array}$ & Reforço Negativo \\
\hline & & $\begin{array}{l}\text { Fatores de Stress } \\
\text { Psicológicos }\end{array}$ & Sugestões Inconsistentes \\
\hline
\end{tabular}




\begin{tabular}{|c|c|c|c|}
\hline & & $\begin{array}{l}\text { Fatores de Stress } \\
\text { Psicológicos }\end{array}$ & $\begin{array}{l}\text { Trabalho M onótono, } \\
\text { Degradante ou Sem Sentido }\end{array}$ \\
\hline & & Fatores Externos & $\begin{array}{l}\text { Ações desenvolvidas por } \\
\text { Supervisores, Colegas, } \\
\text { Representantes de Sindicatos, } \\
\text { e Pessoal de Regulamentação }\end{array}$ \\
\hline & & Fatores Externos & Capacidade Crítica da Tarefa \\
\hline & & Fatores Externos & $\begin{array}{c}\text { Complexidade da Tarefa (Carga } \\
\text { de Informações) }\end{array}$ \\
\hline & & Fatores Externos & Comunicação \\
\hline & & Fatores Externos & Cuidados e Advertências \\
\hline & & Fatores Externos & $\begin{array}{l}\text { Freqüência e Repetitividade da } \\
\text { Tarefa }\end{array}$ \\
\hline & & Fatores Externos & $\begin{array}{c}\text { Horas de Trabalho / Intervalos } \\
\text { de Trabalho }\end{array}$ \\
\hline & & Fatores Externos & Métodos de Trabalho \\
\hline & & Fatores Externos & Políticas da Planta \\
\hline & & Fatores Externos & $\begin{array}{l}\text { Feedback (Conhecimento de } \\
\text { Resultados) }\end{array}$ \\
\hline & & Fatores Externos & $\begin{array}{l}\text { Procedimentos (Escritos ou } \\
\text { Não Escritos) }\end{array}$ \\
\hline$\frac{\pi}{\frac{N}{\sigma}}$ & & Fatores Internos & $\begin{array}{l}\text { Conhecimento de Padrões de } \\
\text { Desempenho }\end{array}$ \\
\hline & & Fatores Internos & Experiência \\
\hline & & Fatores Internos & Nível de cultura de segurança \\
\hline & & Fatores Internos & Nível de cultura organizacional \\
\hline & & Fatores Internos & Nível de práticas \\
\hline & & Fatores Internos & Qualidade do Treinamento \\
\hline & & Fatores Internos & Tensão Mental ou Física \\
\hline & \multirow{15}{*}{$\begin{array}{c}\text { Coordenar a intervenção } \\
\text { com os demais agentes } \\
\text { envolvidos quando } \\
\text { necessário }\end{array}$} & Fatores Cognitivos & Capacidade Analítica \\
\hline & & Fatores Cognitivos & Capacidade de Antecipação \\
\hline & & Fatores Cognitivos & $\begin{array}{c}\text { Capacidade de Tomada de } \\
\text { Decisões }\end{array}$ \\
\hline & & Fatores Cognitivos & Identificação com grupos \\
\hline & & Fatores Cognitivos & $\begin{array}{l}\text { Inteligência numérica } \\
\text { (capacidade de cálculos) }\end{array}$ \\
\hline & & Fatores Cognitivos & Memória \\
\hline 4 & & Fatores Cognitivos & Nível de Atenção \\
\hline & & Fatores Cognitivos & Percepção de séries \\
\hline & & Fatores de Personalidade & Afago \\
\hline & & Fatores de Personalidade & Afiliação \\
\hline & & Fatores de Personalidade & Agressão \\
\hline & & Fatores de Personalidade & Assistência \\
\hline & & Fatores de Personalidade & Autonomia \\
\hline & & Fatores de Personalidade & Desempenho \\
\hline & & Fatores de Personalidade & Dominância \\
\hline
\end{tabular}




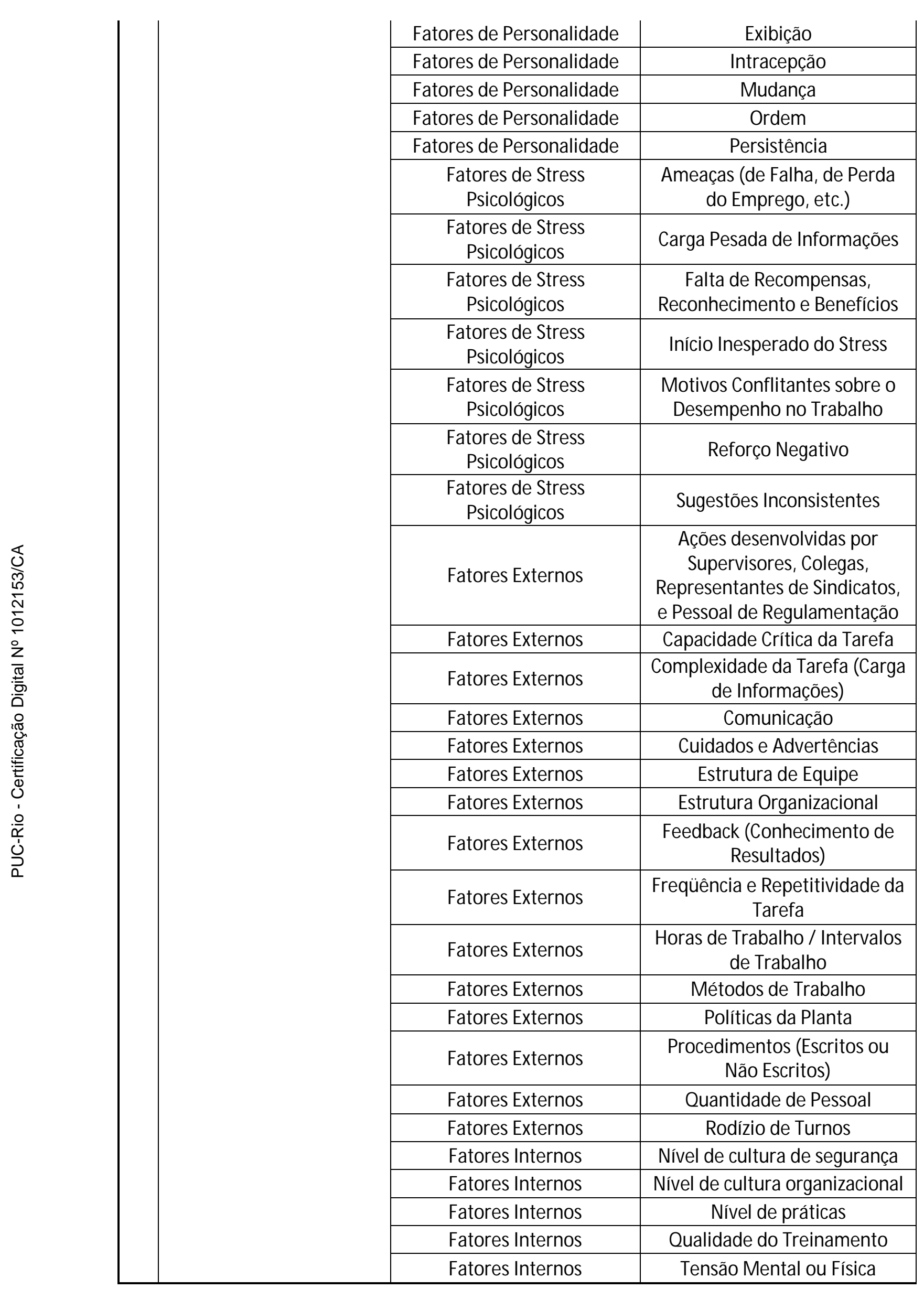




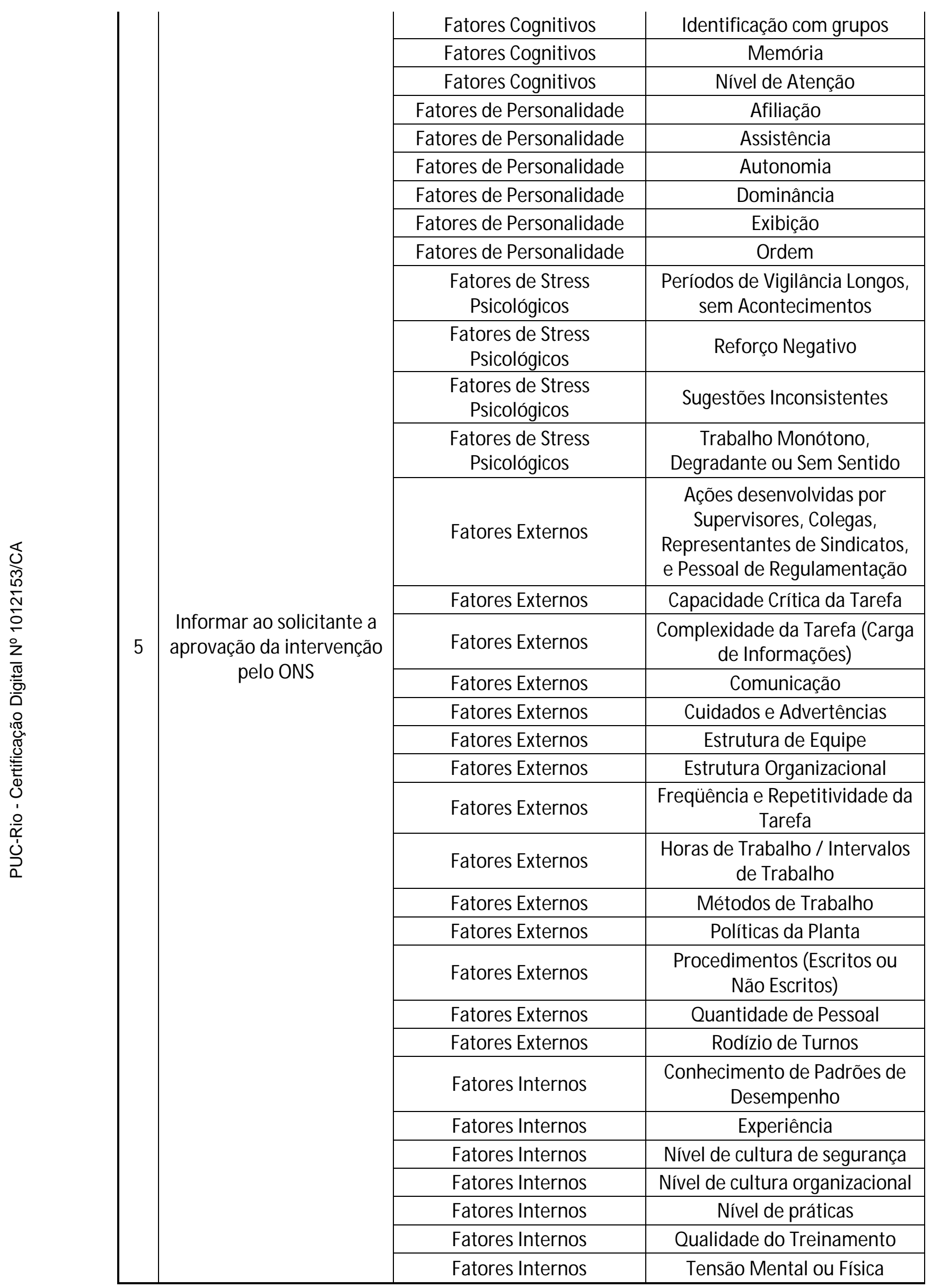




\begin{tabular}{|c|c|c|c|}
\hline & & Fatores Cognitivos & Identificação com grupos \\
\hline & & Fatores Cognitivos & Memória \\
\hline & & Fatores Cognitivos & Nível de Atenção \\
\hline & & Fatores de Personalidade & Afiliação \\
\hline & & Fatores de Personalidade & Assistência \\
\hline & & Fatores de Personalidade & Agressão \\
\hline & & Fatores de Personalidade & Autonomia \\
\hline & & Fatores de Personalidade & Denegação \\
\hline & & Fatores de Personalidade & Dominância \\
\hline & & Fatores de Personalidade & Exibição \\
\hline & & Fatores de Personalidade & Ordem \\
\hline & & $\begin{array}{l}\text { Fatores de Stress } \\
\text { Psicológicos }\end{array}$ & $\begin{array}{l}\text { Períodos de Vigilância Longos, } \\
\text { sem Acontecimentos }\end{array}$ \\
\hline & & $\begin{array}{l}\text { Fatores de Stress } \\
\text { Psicológicos }\end{array}$ & Reforço Negativo \\
\hline & & $\begin{array}{l}\text { Fatores de Stress } \\
\text { Psicológicos }\end{array}$ & Sugestões Inconsistentes \\
\hline & & $\begin{array}{l}\text { Fatores de Stress } \\
\text { Psicológicos }\end{array}$ & $\begin{array}{c}\text { Trabalho M onótono, } \\
\text { Degradante ou Sem Sentido }\end{array}$ \\
\hline 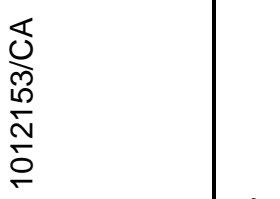 & Informar ao solicitante 0 & Fatores Externos & $\begin{array}{c}\text { Ações desenvolvidas por } \\
\text { Supervisores, Colegas, } \\
\text { Representantes de Sindicatos, } \\
\text { e Pessoal de Regulamentação }\end{array}$ \\
\hline 6 & indeferimento da & Fatores Externos & Capacidade Crítica da Tarefa \\
\hline 震 & & Fatores Externos & $\begin{array}{c}\text { Complexidade da Tarefa (Carga } \\
\text { de Informações) }\end{array}$ \\
\hline & & Fatores Externos & Comunicação \\
\hline & & Fatores Externos & Cuidados e Advertências \\
\hline $\bar{O}$ & & Fatores Externos & Estrutura de Equipe \\
\hline & & Fatores Externos & Estrutura Organizacional \\
\hline & & Fatores Externos & $\begin{array}{c}\text { Freqüência e Repetitividade da } \\
\text { Tarefa }\end{array}$ \\
\hline & & Fatores Externos & $\begin{array}{c}\text { Horas de Trabalho / Intervalos } \\
\text { de Trabalho }\end{array}$ \\
\hline & & Fatores Externos & Métodos de Trabalho \\
\hline & & Fatores Externos & Políticas da Planta \\
\hline & & Fatores Externos & $\begin{array}{l}\text { Procedimentos (Escritos ou } \\
\text { Não Escritos) }\end{array}$ \\
\hline & & Fatores Externos & Quantidade de Pessoal \\
\hline & & Fatores Externos & Rodízio de Turnos \\
\hline & & Fatores Internos & $\begin{array}{l}\text { Conhecimento de Padrões de } \\
\text { Desempenho }\end{array}$ \\
\hline & & Fatores Internos & Experiência \\
\hline & & Fatores Internos & Nível de cultura de segurança \\
\hline & & Fatores Internos & Nível de cultura organizacional \\
\hline & & Fatores Internos & Nível de práticas \\
\hline
\end{tabular}




\begin{tabular}{|c|c|c|c|}
\hline & & Fatores Internos & Qualidade do Treinamento \\
\hline & & Fatores Internos & Tensão Mental ou Física \\
\hline \multirow{32}{*}{7} & \multirow{32}{*}{$\begin{array}{l}\text { Informar ao solicitante a } \\
\text { reprogramação da } \\
\text { intervenção pelo ONS }\end{array}$} & Fatores Cognitivos & Identificação com grupos \\
\hline & & Fatores Cognitivos & Memória \\
\hline & & Fatores Cognitivos & Nível de Atenção \\
\hline & & Fatores de Personalidade & Afiliação \\
\hline & & Fatores de Personalidade & Assistência \\
\hline & & Fatores de Personalidade & Agressão \\
\hline & & Fatores de Personalidade & Autonomia \\
\hline & & Fatores de Personalidade & Denegação \\
\hline & & Fatores de Personalidade & Dominância \\
\hline & & Fatores de Personalidade & Exibição \\
\hline & & Fatores de Personalidade & Ordem \\
\hline & & $\begin{array}{l}\text { Fatores de Stress } \\
\text { Psicológicos }\end{array}$ & $\begin{array}{l}\text { Períodos de Vigilância Longos, } \\
\text { sem Acontecimentos }\end{array}$ \\
\hline & & $\begin{array}{l}\text { Fatores de Stress } \\
\text { Psicológicos }\end{array}$ & Reforço Negativo \\
\hline & & $\begin{array}{l}\text { Fatores de Stress } \\
\text { Psicológicos }\end{array}$ & Sugestões Inconsistentes \\
\hline & & $\begin{array}{l}\text { Fatores de Stress } \\
\text { Psicológicos }\end{array}$ & $\begin{array}{c}\text { Trabalho M onótono, } \\
\text { Degradante ou Sem Sentido }\end{array}$ \\
\hline & & Fatores Externos & $\begin{array}{l}\text { Ações desenvolvidas por } \\
\text { Supervisores, Colegas, } \\
\text { Representantes de Sindicatos, } \\
\text { e Pessoal de Regulamentação }\end{array}$ \\
\hline & & Fatores Externos & Capacidade Crítica da Tarefa \\
\hline & & Fatores Externos & $\begin{array}{c}\text { Complexidade da Tarefa (Carga } \\
\text { de Informações) }\end{array}$ \\
\hline & & Fatores Externos & Comunicação \\
\hline & & Fatores Externos & Cuidados e Advertências \\
\hline & & Fatores Externos & Estrutura de Equipe \\
\hline & & Fatores Externos & Estrutura Organizacional \\
\hline & & Fatores Externos & $\begin{array}{l}\text { Freqüência e Repetitividade da } \\
\text { Tarefa }\end{array}$ \\
\hline & & Fatores Externos & $\begin{array}{c}\text { Horas de Trabalho / Intervalos } \\
\text { de Trabalho }\end{array}$ \\
\hline & & Fatores Externos & M étodos de Trabalho \\
\hline & & Fatores Externos & Políticas da Planta \\
\hline & & Fatores Externos & $\begin{array}{l}\text { Procedimentos (Escritos ou } \\
\text { Não Escritos) }\end{array}$ \\
\hline & & Fatores Externos & Quantidade de Pessoal \\
\hline & & Fatores Externos & Rodízio de Turnos \\
\hline & & Fatores Internos & $\begin{array}{c}\text { Conhecimento de Padrões de } \\
\text { Desempenho }\end{array}$ \\
\hline & & Fatores Internos & Experiência \\
\hline & & Fatores Internos & Nível de cultura de segurança \\
\hline
\end{tabular}




\begin{tabular}{|c|c|c|c|}
\hline & & Fatores Internos & Nível de cultura organizacional \\
\hline & & Fatores Internos & Nível de práticas \\
\hline & & Fatores Internos & Qualidade do Treinamento \\
\hline & & Fatores Internos & Tensão Mental ou Física \\
\hline & & Fatores Cognitivos & Capacidade Analítica \\
\hline & & Fatores Cognitivos & Capacidade de Classificação \\
\hline & & Fatores Cognitivos & $\begin{array}{c}\text { Capacidade de Tomada de } \\
\text { Decisões }\end{array}$ \\
\hline & & Fatores Cognitivos & Memória \\
\hline & & Fatores Cognitivos & $\begin{array}{l}\text { Predisposição para novos } \\
\text { conhecimentos }\end{array}$ \\
\hline & & Fatores Cognitivos & Nível de Atenção \\
\hline & & Fatores de Personalidade & Afago \\
\hline & & Fatores de Personalidade & Afiliação \\
\hline & & Fatores de Personalidade & Agressão \\
\hline & & Fatores de Personalidade & Autonomia \\
\hline & & $\begin{array}{l}\text { Fatores de Stress } \\
\text { Psicológicos }\end{array}$ & Carga Pesada de Informações \\
\hline & & $\begin{array}{l}\text { Fatores de Stress } \\
\text { Psicológicos }\end{array}$ & $\begin{array}{l}\text { Distrações (devido a Ruído, } \\
\text { Clarão, M ovimentos, etc.) }\end{array}$ \\
\hline & Anexar na SI os & $\begin{array}{l}\text { Fatores de Stress } \\
\text { Psicológicos }\end{array}$ & Início Inesperado do Stress \\
\hline & $\begin{array}{l}\text { documentos necessários } \\
\text { para coordenação da }\end{array}$ & $\begin{array}{c}\text { Fatores de Stress } \\
\text { Psicológicos }\end{array}$ & Reforço Negativo \\
\hline 8 & $\begin{array}{l}\text { intervenção em tempo } \\
\text { real (SGI, Al, ATEIE, AISTE, }\end{array}$ & $\begin{array}{l}\text { Fatores de Stress } \\
\text { Psicológicos }\end{array}$ & Sugestões Inconsistentes \\
\hline & e Programa de Manobras) & $\begin{array}{l}\text { Fatores de Stress } \\
\text { Psicológicos }\end{array}$ & $\begin{array}{c}\text { Trabalho M onótono, } \\
\text { Degradante ou Sem Sentido }\end{array}$ \\
\hline & mesmos & Fatores Externos & $\begin{array}{l}\text { Ações desenvolvidas por } \\
\text { Supervisores, Colegas, } \\
\text { Representantes de Sindicatos, } \\
\text { e Pessoal de Regulamentação }\end{array}$ \\
\hline & & Fatores Externos & Capacidade Crítica da Tarefa \\
\hline & & Fatores Externos & $\begin{array}{c}\text { Complexidade da Tarefa (Carga } \\
\text { de Informações) }\end{array}$ \\
\hline & & Fatores Externos & Comunicação \\
\hline & & Fatores Externos & $\begin{array}{c}\text { Fatores de Interface de } \\
\text { Hardware }\end{array}$ \\
\hline & & Fatores Externos & Cuidados e Advertências \\
\hline & & Fatores Externos & $\begin{array}{c}\text { Disponibilidade de } \\
\text { Equipamentos Especiais }\end{array}$ \\
\hline & & Fatores Externos & Estrutura Organizacional \\
\hline & & Fatores Externos & Métodos de Trabalho \\
\hline & & Fatores Externos & Políticas da Planta \\
\hline & & Fatores Externos & $\begin{array}{c}\text { Procedimentos (Escritos ou } \\
\text { Não Escritos) }\end{array}$ \\
\hline
\end{tabular}




\begin{tabular}{|c|c|c|c|}
\hline & & Fatores Internos & $\begin{array}{c}\text { Conhecimento de Padrões de } \\
\text { Desempenho }\end{array}$ \\
\hline & & Fatores Internos & Experiência \\
\hline & & Fatores Internos & Nível de cultura de segurança \\
\hline & & Fatores Internos & Nível de cultura organizacional \\
\hline & & Fatores Internos & Nível de práticas \\
\hline & & Fatores Internos & Qualidade do Treinamento \\
\hline & & Fatores Internos & Tensão M ental ou Física \\
\hline & & Fatores Cognitivos & Memória \\
\hline & & Fatores Cognitivos & Nível de Atenção \\
\hline & & Fatores de Personalidade & Afago \\
\hline & & Fatores de Personalidade & Afiliação \\
\hline & & Fatores de Personalidade & Assistência \\
\hline & & Fatores de Personalidade & Autonomia \\
\hline & & Fatores de Personalidade & Dominância \\
\hline & & Fatores de Personalidade & Exibição \\
\hline & & Fatores de Personalidade & Intracepção \\
\hline & & Fatores de Personalidade & Ordem \\
\hline & & $\begin{array}{l}\text { Fatores de Stress } \\
\text { Psicológicos }\end{array}$ & Carga Pesada de Informações \\
\hline$\frac{m}{\stackrel{n}{N}}$ & & $\begin{array}{l}\text { Fatores de Stress } \\
\text { Psicológicos }\end{array}$ & Início Inesperado do Stress \\
\hline ¿á & & $\begin{array}{l}\text { Fatores de Stress } \\
\text { Psicológicos }\end{array}$ & $\begin{array}{l}\text { Períodos de Vigilância Longos, } \\
\text { sem Acontecimentos }\end{array}$ \\
\hline 衮 & Enviar aos Destinatários & $\begin{array}{l}\text { Fatores de Stress } \\
\text { Psicológicos }\end{array}$ & $\begin{array}{c}\text { Trabalho M onótono, } \\
\text { Degradante ou Sem Sentido }\end{array}$ \\
\hline 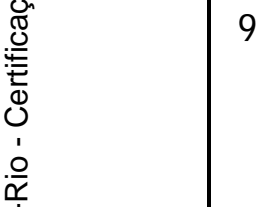 & $\begin{array}{c}\text { mesma já se encontra } \\
\text { autorizada }\end{array}$ & Fatores Externos & $\begin{array}{l}\text { Ações desenvolvidas por } \\
\text { Supervisores, Colegas, } \\
\text { Representantes de Sindicatos, } \\
\text { e Pessoal de Regulamentação }\end{array}$ \\
\hline & & Fatores Externos & Capacidade Crítica da Tarefa \\
\hline & & Fatores Externos & $\begin{array}{c}\text { Complexidade da Tarefa (Carga } \\
\text { de Informações) }\end{array}$ \\
\hline & & & Comunicação \\
\hline & & Fatores Externos & Cuidados e Advertências \\
\hline & & Fatores Externos & $\begin{array}{c}\text { Disponibilidade de } \\
\text { Equipamentos Especiais }\end{array}$ \\
\hline & & Fatores Externos & Estrutura de Equipe \\
\hline & & Fatores Externos & Estrutura Organizacional \\
\hline & & Fatores Externos & $\begin{array}{l}\text { Freqüência e Repetitividade da } \\
\text { Tarefa }\end{array}$ \\
\hline & & Fatores Externos & $\begin{array}{c}\text { Horas de Trabalho / Intervalos } \\
\text { de Trabalho }\end{array}$ \\
\hline & & Fatores Externos & Métodos de Trabalho \\
\hline & & Fatores Externos & Políticas da Planta \\
\hline
\end{tabular}




\begin{tabular}{|c|c|c|c|}
\hline & & Fatores Externos & $\begin{array}{l}\text { Feedback (Conhecimento de } \\
\text { Resultados) }\end{array}$ \\
\hline & & Fatores Externos & $\begin{array}{l}\text { Procedimentos (Escritos ou } \\
\text { Não Escritos) }\end{array}$ \\
\hline & & Fatores Internos & $\begin{array}{l}\text { Conhecimento de Padrões de } \\
\text { Desempenho }\end{array}$ \\
\hline & & Fatores Internos & Experiência \\
\hline & & Fatores Internos & Nível de cultura de segurança \\
\hline & & Fatores Internos & Nível de cultura organizacional \\
\hline & & Fatores Internos & Nível de práticas \\
\hline & & Fatores Internos & Qualidade do Treinamento \\
\hline & & Fatores Internos & Tensão M ental ou Física \\
\hline & & Fatores Cognitivos & Capacidade Analítica \\
\hline & & Fatores Cognitivos & Capacidade de Classificação \\
\hline & & Fatores Cognitivos & $\begin{array}{c}\text { Capacidade de Tomada de } \\
\text { Decisões }\end{array}$ \\
\hline & & Fatores Cognitivos & $\begin{array}{c}\text { Continuidade de matrizes ou } \\
\text { conjuntos }\end{array}$ \\
\hline & & Fatores Cognitivos & $\begin{array}{l}\text { Estruturação do campo } \\
\text { perceptivo (topologia) }\end{array}$ \\
\hline$\stackrel{\substack{\text { D. } \\
\sim}}{\sim}$ & & Fatores Cognitivos & $\begin{array}{l}\text { Inteligência numérica } \\
\text { (capacidade de cálculos) }\end{array}$ \\
\hline & & Fatores Cognitivos & Memória \\
\hline 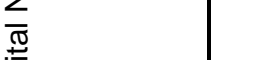 & & Fatores Cognitivos & Nível de Atenção \\
\hline $\bar{a}$ & & Fatores Cognitivos & Percepção de séries \\
\hline 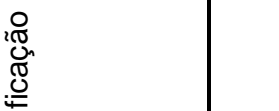 & $\begin{array}{c}\text { Realizar contatos } \\
\text { necessários relatando a }\end{array}$ & Fatores Cognitivos & $\begin{array}{l}\text { Predisposição para novos } \\
\text { conhecimentos }\end{array}$ \\
\hline & ocorrência com precisão, & Fatores de Personalidade & Afago \\
\hline 10 & quando houver tentativa & Fatores de Personalidade & Afiliação \\
\hline 誉 & de energizaçao sem & Fatores de Personalidade & Agressão \\
\hline & $\begin{array}{l}\text { sucesso, com Inaicaçao } \\
\text { de falta nermanente }\end{array}$ & Fatores de Personalidade & Autonomia \\
\hline & & Fatores de Personalidade & Denegação \\
\hline & & Fatores de Personalidade & Exibição \\
\hline & & Fatores de Personalidade & Intracepção \\
\hline & & Fatores de Personalidade & Mudança \\
\hline & & Fatores de Personalidade & Ordem \\
\hline & & Fatores de Personalidade & Persistência \\
\hline & & $\begin{array}{l}\text { Fatores de Stress } \\
\text { Fisiológicos }\end{array}$ & Fome ou Sede \\
\hline & & $\begin{array}{l}\text { Fatores de Stress } \\
\text { Fisiológicos }\end{array}$ & $\begin{array}{c}\text { Interrupção do Ritmo } \\
\text { Circadiano }\end{array}$ \\
\hline & & $\begin{array}{l}\text { Fatores de Stress } \\
\text { Fisiológicos }\end{array}$ & Longa Duração do Stress \\
\hline & & $\begin{array}{l}\text { Fatores de Stress } \\
\text { Fisiológicos }\end{array}$ & Repetição de Movimentos \\
\hline
\end{tabular}




\begin{tabular}{|c|c|}
\hline $\begin{array}{l}\text { Fatores de Stress } \\
\text { Psicológicos }\end{array}$ & $\begin{array}{c}\text { Alta Velocidade na Execução } \\
\text { da Tarefa }\end{array}$ \\
\hline $\begin{array}{l}\text { Fatores de Stress } \\
\text { Psicológicos }\end{array}$ & $\begin{array}{c}\text { Ameaças (de Falha, de Perda } \\
\text { do Emprego, etc.) }\end{array}$ \\
\hline $\begin{array}{l}\text { Fatores de Stress } \\
\text { Psicológicos }\end{array}$ & Carga Pesada de Informações \\
\hline $\begin{array}{l}\text { Fatores de Stress } \\
\text { Psicológicos }\end{array}$ & $\begin{array}{c}\text { Falta de Recompensas, } \\
\text { Reconhecimento e Benefícios }\end{array}$ \\
\hline $\begin{array}{l}\text { Fatores de Stress } \\
\text { Psicológicos }\end{array}$ & Início Inesperado do Stress \\
\hline $\begin{array}{l}\text { Fatores de Stress } \\
\text { Psicológicos }\end{array}$ & $\begin{array}{c}\text { Motivos Conflitantes sobre o } \\
\text { Desempenho no Trabalho }\end{array}$ \\
\hline $\begin{array}{l}\text { Fatores de Stress } \\
\text { Psicológicos }\end{array}$ & Reforço Negativo \\
\hline $\begin{array}{l}\text { Fatores de Stress } \\
\text { Psicológicos }\end{array}$ & Sugestões Inconsistentes \\
\hline $\begin{array}{l}\text { Fatores de Stress } \\
\text { Psicológicos }\end{array}$ & $\begin{array}{c}\text { Trabalho M onótono, } \\
\text { Degradante ou Sem Sentido }\end{array}$ \\
\hline Fatores Externos & $\begin{array}{c}\text { Ações desenvolvidas por } \\
\text { Supervisores, Colegas, } \\
\text { Representantes de Sindicatos, } \\
\text { e Pessoal de Regulamentação }\end{array}$ \\
\hline Fatores Externos & Capacidade Crítica da Tarefa \\
\hline Fatores Externos & $\begin{array}{c}\text { Complexidade da Tarefa (Carga } \\
\text { de Informações) }\end{array}$ \\
\hline Fatores Externos & Comunicação \\
\hline Fatores Externos & Cuidados e Advertências \\
\hline Fatores Externos & $\begin{array}{c}\text { Fatores de Interface de } \\
\text { Hardware }\end{array}$ \\
\hline Fatores Externos & Estrutura de Equipe \\
\hline Fatores Externos & Estrutura Organizacional \\
\hline Fatores Externos & $\begin{array}{l}\text { Feedback (Conhecimento de } \\
\text { Resultados) }\end{array}$ \\
\hline Fatores Externos & Métodos de Trabalho \\
\hline Fatores Externos & Políticas da Planta \\
\hline Fatores Externos & $\begin{array}{l}\text { Procedimentos (Escritos ou } \\
\text { Não Escritos) }\end{array}$ \\
\hline Fatores Internos & $\begin{array}{l}\text { Conhecimento de Padrões de } \\
\text { Desempenho }\end{array}$ \\
\hline Fatores Internos & Experiência \\
\hline Fatores Internos & Nível de cultura de segurança \\
\hline Fatores Internos & Nível de cultura organizacional \\
\hline Fatores Internos & Nível de práticas \\
\hline Fatores Internos & Qualidade do Treinamento \\
\hline Fatores Internos & Tensão Mental ou Física \\
\hline
\end{tabular}


Tabela 20: Associação de tarefas do Procedimento para Programação de Intervenção em Urgência ou Emergência com PSFs pertinentes

\begin{tabular}{|c|c|c|c|}
\hline \multicolumn{4}{|c|}{ Procedimento para Recomposição } \\
\hline & Tarefas & Grupo de PSFs & PSF \\
\hline \multirow{28}{*}{1} & \multirow{28}{*}{$\begin{array}{c}\text { Identificar a configuração } \\
\text { das SE's envolvidas após a } \\
\text { ocorrência, } \\
\text { reconhecendo o estado } \\
\text { dos disjuntores nas telas } \\
\text { dos diagramas unifilares } \\
\text { gerais e também de cada } \\
\text { SE }\end{array}$} & Fatores Cognitivos & Capacidade Analítica \\
\hline & & Fatores Cognitivos & Capacidade de Classificação \\
\hline & & Fatores Cognitivos & $\begin{array}{l}\text { Capacidade de Tomada de } \\
\text { Decisões }\end{array}$ \\
\hline & & Fatores Cognitivos & $\begin{array}{l}\text { Continuidade de matrizes ou } \\
\text { conjuntos }\end{array}$ \\
\hline & & Fatores Cognitivos & $\begin{array}{l}\text { Estruturação do campo } \\
\text { perceptivo (topologia) }\end{array}$ \\
\hline & & Fatores Cognitivos & Memória \\
\hline & & Fatores Cognitivos & Nível de Atenção \\
\hline & & Fatores Cognitivos & Percepção de séries \\
\hline & & Fatores Cognitivos & $\begin{array}{l}\text { Predisposição para novos } \\
\text { conhecimentos }\end{array}$ \\
\hline & & Fatores de Personalidade & Desempenho \\
\hline & & Fatores de Personalidade & Exibição \\
\hline & & Fatores de Personalidade & Intracepção \\
\hline & & Fatores de Personalidade & Mudança \\
\hline & & Fatores de Personalidade & Ordem \\
\hline & & $\begin{array}{l}\text { Fatores de Stress } \\
\text { Psicológicos }\end{array}$ & $\begin{array}{c}\text { Ameaças (de Falha, de Perda } \\
\text { do Emprego, etc.) }\end{array}$ \\
\hline & & $\begin{array}{l}\text { Fatores de Stress } \\
\text { Psicológicos }\end{array}$ & Carga Pesada de Informações \\
\hline & & $\begin{array}{l}\text { Fatores de Stress } \\
\text { Psicológicos }\end{array}$ & $\begin{array}{l}\text { Distrações (devido a Ruído, } \\
\text { Clarão, M ovimentos, etc.) }\end{array}$ \\
\hline & & $\begin{array}{l}\text { Fatores de Stress } \\
\text { Psicológicos }\end{array}$ & $\begin{array}{c}\text { Falta de Recompensas, } \\
\text { Reconhecimento e Benefícios }\end{array}$ \\
\hline & & $\begin{array}{l}\text { Fatores de Stress } \\
\text { Psicológicos }\end{array}$ & Início Inesperado do Stress \\
\hline & & $\begin{array}{l}\text { Fatores de Stress } \\
\text { Psicológicos }\end{array}$ & $\begin{array}{l}\text { Motivos Conflitantes sobre } 0 \\
\text { Desempenho no Trabalho }\end{array}$ \\
\hline & & $\begin{array}{l}\text { Fatores de Stress } \\
\text { Psicológicos }\end{array}$ & Perda de Sensibilidade \\
\hline & & $\begin{array}{l}\text { Fatores de Stress } \\
\text { Psicológicos }\end{array}$ & Reforço Negativo \\
\hline & & $\begin{array}{l}\text { Fatores de Stress } \\
\text { Psicológicos }\end{array}$ & Sugestões Inconsistentes \\
\hline & & Fatores Externos & Capacidade Crítica da Tarefa \\
\hline & & Fatores Externos & $\begin{array}{l}\text { Complexidade da Tarefa (Carga } \\
\text { de Informações) }\end{array}$ \\
\hline & & Fatores Externos & Cuidados e Advertências \\
\hline & & Fatores Externos & $\begin{array}{c}\text { Disponibilidade de } \\
\text { Equipamentos Especiais }\end{array}$ \\
\hline & & Fatores Externos & Estrutura Organizacional \\
\hline
\end{tabular}




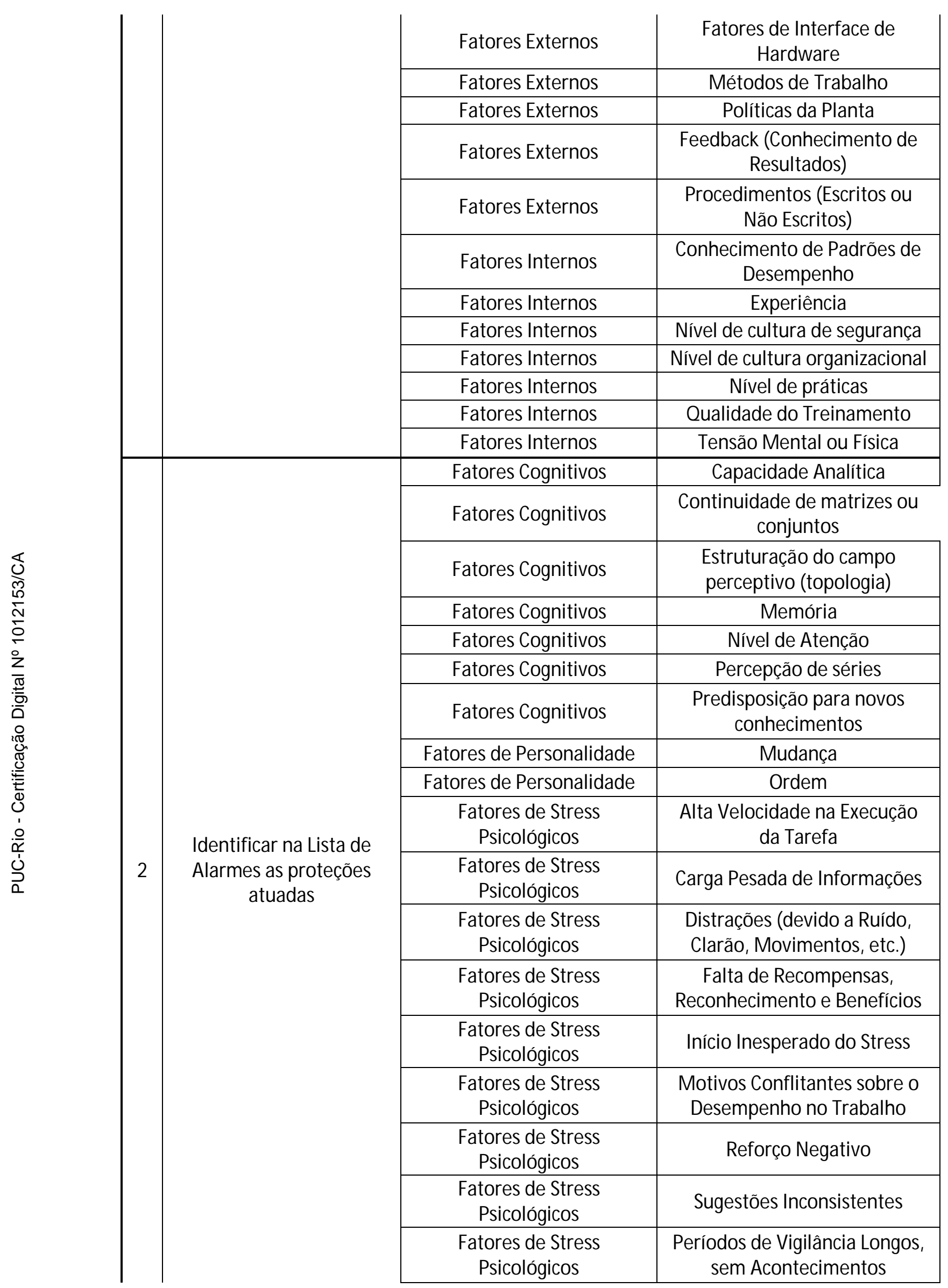




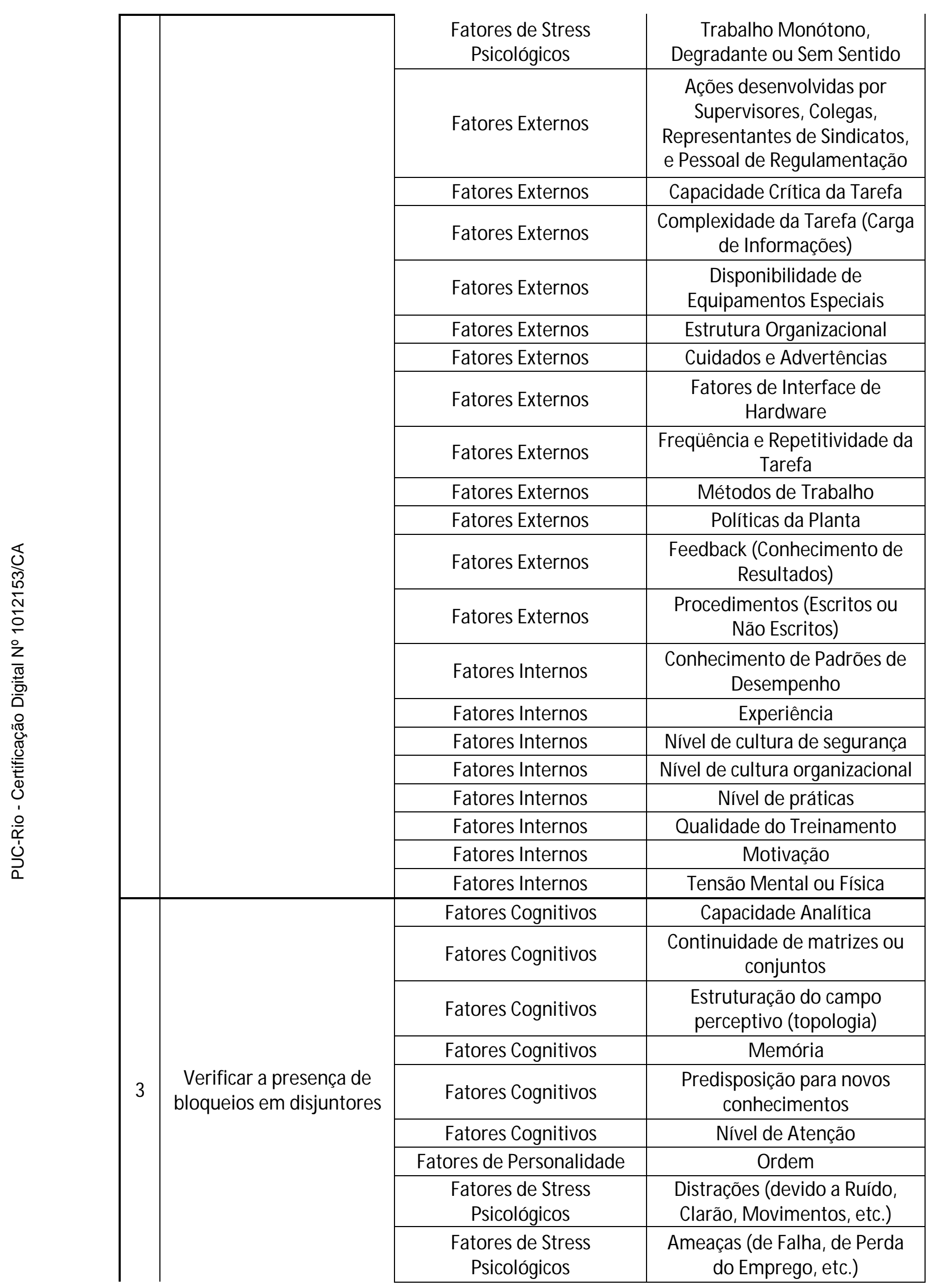




\begin{tabular}{|c|c|c|c|}
\hline & & $\begin{array}{l}\text { Fatores de Stress } \\
\text { Psicológicos }\end{array}$ & $\begin{array}{c}\text { Falta de Recompensas, } \\
\text { Reconhecimento e Benefícios }\end{array}$ \\
\hline & & $\begin{array}{l}\text { Fatores de Stress } \\
\text { Psicológicos }\end{array}$ & $\begin{array}{l}\text { Motivos Conflitantes sobre } 0 \\
\text { Desempenho no Trabalho }\end{array}$ \\
\hline & & $\begin{array}{l}\text { Fatores de Stress } \\
\text { Psicológicos }\end{array}$ & Início Inesperado do Stress \\
\hline & & $\begin{array}{l}\text { Fatores de Stress } \\
\text { Psicológicos }\end{array}$ & $\begin{array}{l}\text { Períodos de Vigilância Longos, } \\
\text { sem Acontecimentos }\end{array}$ \\
\hline & & $\begin{array}{l}\text { Fatores de Stress } \\
\text { Psicológicos }\end{array}$ & Reforço Negativo \\
\hline & & $\begin{array}{l}\text { Fatores de Stress } \\
\text { Psicológicos }\end{array}$ & Sugestões Inconsistentes \\
\hline & & $\begin{array}{l}\text { Fatores de Stress } \\
\text { Psicológicos }\end{array}$ & $\begin{array}{l}\text { Trabalho M onótono, } \\
\text { Degradante ou Sem Sentido }\end{array}$ \\
\hline & & Fatores Externos & $\begin{array}{l}\text { Ações desenvolvidas por } \\
\text { Supervisores, Colegas, } \\
\text { Representantes de Sindicatos, } \\
\text { e Pessoal de Regulamentação }\end{array}$ \\
\hline & & Fatores Externos & $\begin{array}{c}\text { Disponibilidade de } \\
\text { Equipamentos Especiais }\end{array}$ \\
\hline 岕 & & Fatores Externos & $\begin{array}{l}\text { Freqüência e Repetitividade da } \\
\text { Tarefa }\end{array}$ \\
\hline$\overbrace{0}^{2}$ & & Fatores Externos & Métodos de Trabalho \\
\hline$\stackrel{2}{2}$ & & Fatores Externos & Políticas da Planta \\
\hline 高 & & Fatores Externos & $\begin{array}{l}\text { Feedback (Conhecimento de } \\
\text { Resultados) }\end{array}$ \\
\hline ? & & Fatores Externos & $\begin{array}{l}\text { Procedimentos (Escritos ou } \\
\text { Não Escritos) }\end{array}$ \\
\hline $\begin{array}{l}\frac{t}{0} \\
0 \\
0\end{array}$ & & Fatores Internos & $\begin{array}{c}\text { Conhecimento de Padrões de } \\
\text { Desempenho }\end{array}$ \\
\hline & & Fatores Internos & Experiência \\
\hline 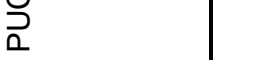 & & Fatores Internos & Nível de cultura de segurança \\
\hline & & Fatores Internos & Nível de cultura organizacional \\
\hline & & Fatores Internos & Tensão Mental ou Física \\
\hline & & Fatores Cognitivos & Capacidade de Classificação \\
\hline & & Fatores Cognitivos & Memória \\
\hline & Verificar a existência de & Fatores Cognitivos & Nível de Atenção \\
\hline & documento de & Fatores de Personalidade & Afago \\
\hline & & Fatores de Personalidade & Autonomia \\
\hline 4 & equipe de campo para & Fatores de Personalidade & Ordem \\
\hline & $\begin{array}{l}\text { recomposição da função } \\
\text { transmissão ou disjuntor }\end{array}$ & $\begin{array}{l}\text { Fatores de Stress } \\
\text { Psicológicos }\end{array}$ & $\begin{array}{c}\text { Ameaças (de Falha, de Perda } \\
\text { do Emprego, etc.) }\end{array}$ \\
\hline & $\begin{array}{l}\text { que sofreu o } \\
\text { desligamento }\end{array}$ & $\begin{array}{l}\text { Fatores de Stress } \\
\text { Psicológicos }\end{array}$ & $\begin{array}{c}\text { Falta de Recompensas, } \\
\text { Reconhecimento e Benefícios }\end{array}$ \\
\hline & & $\begin{array}{l}\text { Fatores de Stress } \\
\text { Psicológicos }\end{array}$ & Início Inesperado do Stress \\
\hline
\end{tabular}




\begin{tabular}{|c|c|c|c|}
\hline & & $\begin{array}{l}\text { Fatores de Stress } \\
\text { Psicológicos }\end{array}$ & $\begin{array}{c}\text { Motivos Conflitantes sobre } 0 \\
\text { Desempenho no Trabalho }\end{array}$ \\
\hline & & $\begin{array}{l}\text { Fatores de Stress } \\
\text { Psicológicos }\end{array}$ & Reforço Negativo \\
\hline & & $\begin{array}{l}\text { Fatores de Stress } \\
\text { Psicológicos }\end{array}$ & Sugestões Inconsistentes \\
\hline & & $\begin{array}{l}\text { Fatores de Stress } \\
\text { Psicológicos }\end{array}$ & $\begin{array}{l}\text { Trabalho M onótono, } \\
\text { Degradante ou Sem Sentido }\end{array}$ \\
\hline & & Fatores Externos & $\begin{array}{l}\text { Ações desenvolvidas por } \\
\text { Supervisores, Colegas, } \\
\text { Representantes de Sindicatos, } \\
\text { e Pessoal de Regulamentação }\end{array}$ \\
\hline & & Fatores Externos & Capacidade Crítica da Tarefa \\
\hline & & Fatores Externos & $\begin{array}{c}\text { Complexidade da Tarefa (Carga } \\
\text { de Informações) }\end{array}$ \\
\hline & & Fatores Externos & Comunicação \\
\hline & & Fatores Externos & Cuidados e Advertências \\
\hline & & Fatores Externos & Estrutura Organizacional \\
\hline & & Fatores Externos & Estrutura de Equipe \\
\hline & & Fatores Externos & Métodos de Trabalho \\
\hline & & Fatores Externos & Políticas da Planta \\
\hline 商 & & Fatores Externos & $\begin{array}{l}\text { Feedback (Conhecimento de } \\
\text { Resultados) }\end{array}$ \\
\hline$\frac{2}{\frac{\pi}{0.0}}$ & & Fatores Externos & $\begin{array}{l}\text { Procedimentos (Escritos ou } \\
\text { Não Escritos) }\end{array}$ \\
\hline & & Fatores Internos & Nível de cultura de segurança \\
\hline & & Fatores Internos & Nível de cultura organizacional \\
\hline & & Fatores Internos & Nível de práticas \\
\hline & & Fatores Internos & Qualidade do Treinamento \\
\hline 으 & & Fatores Internos & Tensão M ental ou Física \\
\hline & & Fatores Cognitivos & Capacidade Analítica \\
\hline & & Fatores Cognitivos & Capacidade de Classificação \\
\hline & & Fatores Cognitivos & Memória \\
\hline & & Fatores Cognitivos & Nível de Atenção \\
\hline & Disponibilizar para & Fatores de Personalidade & Afago \\
\hline & operação a função & Fatores de Personalidade & Afiliação \\
\hline & transmissão ou disjuntor & Fatores de Personalidade & Assistência \\
\hline 5 & que sofreu 0 & Fatores de Personalidade & Mudança \\
\hline & desligamento ao Centro & Fatores de Personalidade & Ordem \\
\hline & correspondente & $\begin{array}{l}\text { Fatores de Stress } \\
\text { Psicológicos }\end{array}$ & Carga Pesada de Informações \\
\hline & & $\begin{array}{l}\text { Fatores de Stress } \\
\text { Psicológicos }\end{array}$ & Início Inesperado do Stress \\
\hline & & $\begin{array}{l}\text { Fatores de Stress } \\
\text { Psicológicos }\end{array}$ & $\begin{array}{c}\text { Ameaças (de Falha, de Perda } \\
\text { do Emprego, etc.) }\end{array}$ \\
\hline
\end{tabular}




\begin{tabular}{|c|c|c|c|}
\hline & & $\begin{array}{l}\text { Fatores de Stress } \\
\text { Psicológicos }\end{array}$ & $\begin{array}{c}\text { Falta de Recompensas, } \\
\text { Reconhecimento e Benefícios }\end{array}$ \\
\hline & & $\begin{array}{l}\text { Fatores de Stress } \\
\text { Psicológicos }\end{array}$ & $\begin{array}{c}\text { Motivos Conflitantes sobre o } \\
\text { Desempenho no Trabalho }\end{array}$ \\
\hline & & $\begin{array}{l}\text { Fatores de Stress } \\
\text { Psicológicos }\end{array}$ & Reforço Negativo \\
\hline & & $\begin{array}{l}\text { Fatores de Stress } \\
\text { Psicológicos }\end{array}$ & Sugestões Inconsistentes \\
\hline & & $\begin{array}{c}\text { Fatores de Stress } \\
\text { Psicológicos }\end{array}$ & $\begin{array}{c}\text { Trabalho M onótono, } \\
\text { Degradante ou Sem Sentido }\end{array}$ \\
\hline & & Fatores Externos & $\begin{array}{l}\text { Ações desenvolvidas por } \\
\text { Supervisores, Colegas, } \\
\text { Representantes de Sindicatos, } \\
\text { e Pessoal de Regulamentação }\end{array}$ \\
\hline & & Fatores Externos & Capacidade Crítica da Tarefa \\
\hline & & Fatores Externos & $\begin{array}{c}\text { Complexidade da Tarefa (Carga } \\
\text { de Informações) }\end{array}$ \\
\hline & & Fatores Externos & Comunicação \\
\hline & & Fatores Externos & Cuidados e Advertências \\
\hline & & Fatores Externos & Estrutura de Equipe \\
\hline ్ֻల్ & & Fatores Externos & Estrutura Organizacional \\
\hline$\stackrel{\sim}{ָ}$ & & Fatores Externos & Métodos de Trabalho \\
\hline 은 & & Fatores Externos & Políticas da Planta \\
\hline$\frac{2}{\frac{\pi}{0}}$ & & Fatores Externos & $\begin{array}{l}\text { Feedback (Conhecimento de } \\
\text { Resultados) }\end{array}$ \\
\hline 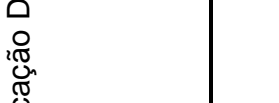 & & Fatores Externos & $\begin{array}{l}\text { Procedimentos (Escritos ou } \\
\text { Não Escritos) }\end{array}$ \\
\hline 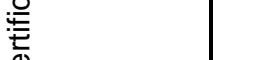 & & Fatores Internos & Nível de cultura de segurança \\
\hline$\bigcup_{1}^{0}$ & & Fatores Internos & Nível de cultura organizacional \\
\hline$\stackrel{ㅇ}{\sim}$ & & Fatores Internos & Nível de práticas \\
\hline ن̀ & & Fatores Internos & Qualidade do Treinamento \\
\hline & & Fatores Internos & Tensão Mental ou Física \\
\hline & & Fatores Cognitivos & Capacidade Analítica \\
\hline & & Fatores Cognitivos & $\begin{array}{l}\text { Continuidade de matrizes ou } \\
\text { conjuntos }\end{array}$ \\
\hline & Identificar com o Centro & Fatores Cognitivos & $\begin{array}{l}\text { Inteligência numérica } \\
\text { (capacidade de cálculos) }\end{array}$ \\
\hline & de Operação do ONS & Fatores Cognitivos & Memória \\
\hline 6 & correspondente a & Fatores Cognitivos & Nível de Atenção \\
\hline & característica do & Fatores Cognitivos & Percepção de séries \\
\hline & desligamento (simples ou & Fatores de Personalidade & Afago \\
\hline & & Fatores de Personalidade & Afiliação \\
\hline & & Fatores de Personalidade & Agressão \\
\hline & & Fatores de Personalidade & Autonomia \\
\hline & & Fatores de Personalidade & Exibição \\
\hline & & Fatores de Personalidade & Intracepção \\
\hline
\end{tabular}




\begin{tabular}{|c|c|c|c|}
\hline & & Fatores de Personalidade & Mudança \\
\hline & & Fatores de Personalidade & Ordem \\
\hline & & $\begin{array}{l}\text { Fatores de Stress } \\
\text { Psicológicos }\end{array}$ & $\begin{array}{c}\text { Alta Velocidade na Execução } \\
\text { da Tarefa }\end{array}$ \\
\hline & & $\begin{array}{l}\text { Fatores de Stress } \\
\text { Psicológicos }\end{array}$ & $\begin{array}{c}\text { Ameaças (de Falha, de Perda } \\
\text { do Emprego, etc.) }\end{array}$ \\
\hline & & $\begin{array}{l}\text { Fatores de Stress } \\
\text { Psicológicos }\end{array}$ & $\begin{array}{c}\text { Falta de Recompensas, } \\
\text { Reconhecimento e Benefícios }\end{array}$ \\
\hline & & $\begin{array}{l}\text { Fatores de Stress } \\
\text { Psicológicos }\end{array}$ & Início Inesperado do Stress \\
\hline & & $\begin{array}{l}\text { Fatores de Stress } \\
\text { Psicológicos }\end{array}$ & $\begin{array}{l}\text { Motivos Conflitantes sobre o } \\
\text { Desempenho no Trabalho }\end{array}$ \\
\hline & & $\begin{array}{l}\text { Fatores de Stress } \\
\text { Psicológicos }\end{array}$ & Reforço Negativo \\
\hline & & $\begin{array}{l}\text { Fatores de Stress } \\
\text { Psicológicos }\end{array}$ & Sugestões Inconsistentes \\
\hline & & $\begin{array}{l}\text { Fatores de Stress } \\
\text { Psicológicos }\end{array}$ & $\begin{array}{c}\text { Trabalho M onótono, } \\
\text { Degradante ou Sem Sentido }\end{array}$ \\
\hline 㐫 & & Fatores Externos & $\begin{array}{l}\text { Ações desenvolvidas por } \\
\text { Supervisores, Colegas, } \\
\text { Representantes de Sindicatos, } \\
\text { e Pessoal de Regulamentação }\end{array}$ \\
\hline$\tilde{O}^{\mathrm{N}}$ & & Fatores Externos & Capacidade Crítica da Tarefa \\
\hline$\frac{\bar{a}}{\frac{1}{0}}$ & & Fatores Externos & $\begin{array}{c}\text { Complexidade da Tarefa (Carga } \\
\text { de Informações) }\end{array}$ \\
\hline o & & Fatores Externos & Comunicação \\
\hline & & Fatores Externos & Cuidados e Advertências \\
\hline $\begin{array}{l}\frac{E}{0} \\
0 \\
0\end{array}$ & & Fatores Externos & Estrutura de Equipe \\
\hline & & Fatores Externos & Estrutura Organizacional \\
\hline 容 & & Fatores Externos & $\begin{array}{c}\text { Feedback (Conhecimento de } \\
\text { Resultados) }\end{array}$ \\
\hline & & Fatores Externos & Métodos de Trabalho \\
\hline & & Fatores Externos & Políticas da Planta \\
\hline & & Fatores Externos & $\begin{array}{l}\text { Procedimentos (Escritos ou } \\
\text { Não Escritos) }\end{array}$ \\
\hline & & Fatores Internos & $\begin{array}{c}\text { Conhecimento de Padrões de } \\
\text { Desempenho }\end{array}$ \\
\hline & & Fatores Internos & Experiência \\
\hline & & Fatores Internos & Nível de cultura de segurança \\
\hline & & Fatores Internos & Nível de cultura organizacional \\
\hline & Solicitar autorização ao & Fatores Cognitivos & Capacidade de Classificação \\
\hline & Centro de Operação do & Fatores Cognitivos & Capacidade de antecipação \\
\hline 7 & $\begin{array}{l}\text { ONS correspondente para } \\
\text { normalização da função }\end{array}$ & Fatores Cognitivos & $\begin{array}{c}\text { Capacidade de Tomada de } \\
\text { Decisões }\end{array}$ \\
\hline & transmissão ou do & Fatores Cognitivos & Memória \\
\hline & disjuntor que sofreu o & Fatores Cognitivos & Nível de Atenção \\
\hline
\end{tabular}




\begin{tabular}{|c|c|c|c|}
\hline & desligamento & Fatores de Personalidade & Afago \\
\hline & & Fatores de Personalidade & Afiliação \\
\hline & & Fatores de Personalidade & Agressão \\
\hline & & Fatores de Personalidade & Autonomia \\
\hline & & Fatores de Personalidade & Intracepção \\
\hline & & Fatores de Personalidade & Mudança \\
\hline & & Fatores de Personalidade & Ordem \\
\hline & & $\begin{array}{l}\text { Fatores de Stress } \\
\text { Psicológicos }\end{array}$ & $\begin{array}{c}\text { Alta Velocidade na Execução } \\
\text { da Tarefa }\end{array}$ \\
\hline & & $\begin{array}{l}\text { Fatores de Stress } \\
\text { Psicológicos }\end{array}$ & Carga Pesada de Informações \\
\hline & & $\begin{array}{l}\text { Fatores de Stress } \\
\text { Psicológicos }\end{array}$ & Início Inesperado do Stress \\
\hline & & $\begin{array}{l}\text { Fatores de Stress } \\
\text { Psicológicos }\end{array}$ & $\begin{array}{c}\text { Ameaças (de Falha, de Perda } \\
\text { do Emprego, etc.) }\end{array}$ \\
\hline & & $\begin{array}{l}\text { Fatores de Stress } \\
\text { Psicológicos }\end{array}$ & $\begin{array}{c}\text { Falta de Recompensas, } \\
\text { Reconhecimento e Benefícios }\end{array}$ \\
\hline & & $\begin{array}{l}\text { Fatores de Stress } \\
\text { Psicológicos }\end{array}$ & $\begin{array}{l}\text { Motivos Conflitantes sobre } 0 \\
\text { Desempenho no Trabalho }\end{array}$ \\
\hline & & $\begin{array}{l}\text { Fatores de Stress } \\
\text { Psicológicos }\end{array}$ & Reforço Negativo \\
\hline$\frac{\bar{N}}{0}$ & & $\begin{array}{l}\text { Fatores de Stress } \\
\text { Psicológicos }\end{array}$ & Sugestões Inconsistentes \\
\hline$\frac{\text { al }}{\sigma}$ & & $\begin{array}{l}\text { Fatores de Stress } \\
\text { Psicológicos }\end{array}$ & $\begin{array}{c}\text { Trabalho M onótono, } \\
\text { Degradante ou Sem Sentido }\end{array}$ \\
\hline 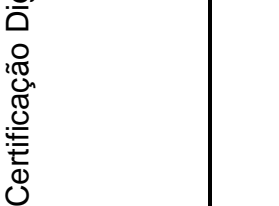 & & Fatores Externos & $\begin{array}{c}\text { Ações desenvolvidas por } \\
\text { Supervisores, Colegas, } \\
\text { Representantes de Sindicatos, } \\
\text { e Pessoal de Regulamentação }\end{array}$ \\
\hline$\stackrel{1}{0}$ & & Fatores Externos & Capacidade Crítica da Tarefa \\
\hline & & Fatores Externos & Comunicação \\
\hline & & Fatores Externos & Cuidados e Advertências \\
\hline & & Fatores Externos & Estrutura Organizacional \\
\hline & & Fatores Externos & $\begin{array}{c}\text { Feedback (Conhecimento de } \\
\text { Resultados) }\end{array}$ \\
\hline & & Fatores Externos & $\begin{array}{l}\text { Freqüência e Repetitividade da } \\
\text { Tarefa }\end{array}$ \\
\hline & & Fatores Externos & Métodos de Trabalho \\
\hline & & Fatores Externos & Políticas da Planta \\
\hline & & Fatores Externos & $\begin{array}{l}\text { Procedimentos (Escritos ou } \\
\text { Não Escritos) }\end{array}$ \\
\hline & & Fatores Internos & Nível de cultura de segurança \\
\hline & & Fatores Internos & Nível de cultura organizacional \\
\hline & & Fatores Internos & Tensão Mental ou Física \\
\hline 8 & Receber autorização do & Fatores Cognitivos & Memória \\
\hline 0 & Centro de Operação do & Fatores Cognitivos & Nível de Atenção \\
\hline
\end{tabular}




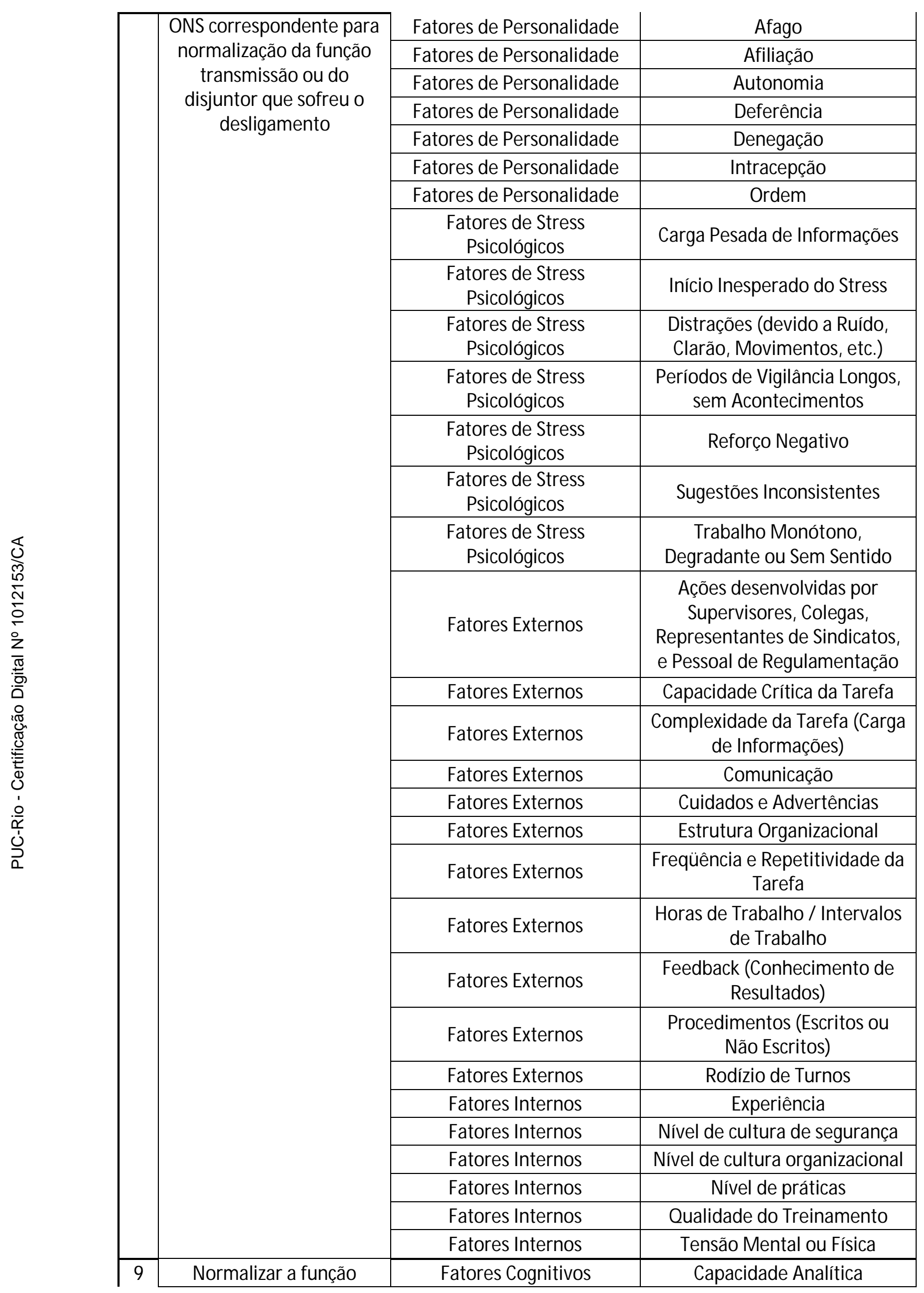




\begin{tabular}{|c|c|c|}
\hline \multirow{28}{*}{$\begin{array}{l}\text { disjuntor que sofreu o } \\
\text { desligamento, em } \\
\text { conformidade com as IO's } \\
\text { de recomposição do ONS }\end{array}$} & Fatores Cognitivos & Capacidade de Classificação \\
\hline & Fatores Cognitivos & $\begin{array}{c}\text { Capacidade de Tomada de } \\
\text { Decisões }\end{array}$ \\
\hline & Fatores Cognitivos & Memória \\
\hline & Fatores Cognitivos & Nível de Atenção \\
\hline & Fatores de Personalidade & Afago \\
\hline & Fatores de Personalidade & Afiliação \\
\hline & Fatores de Personalidade & Autonomia \\
\hline & Fatores de Personalidade & Desempenho \\
\hline & Fatores de Personalidade & Mudança \\
\hline & Fatores de Personalidade & Ordem \\
\hline & Fatores de Personalidade & Persistência \\
\hline & $\begin{array}{l}\text { Fatores de Stress } \\
\text { Fisiológicos }\end{array}$ & Exercício Físico \\
\hline & $\begin{array}{l}\text { Fatores de Stress } \\
\text { Fisiológicos }\end{array}$ & Fadiga \\
\hline & $\begin{array}{l}\text { Fatores de Stress } \\
\text { Fisiológicos }\end{array}$ & Fome ou Sede \\
\hline & $\begin{array}{l}\text { Fatores de Stress } \\
\text { Fisiológicos }\end{array}$ & $\begin{array}{l}\text { Interrupção do Ritmo } \\
\text { Circadiano }\end{array}$ \\
\hline & $\begin{array}{l}\text { Fatores de Stress } \\
\text { Fisiológicos }\end{array}$ & Longa Duração do Stress \\
\hline & $\begin{array}{l}\text { Fatores de Stress } \\
\text { Fisiológicos } \\
\end{array}$ & Repetição de M ovimentos \\
\hline & $\begin{array}{l}\text { Fatores de Stress } \\
\text { Psicológicos }\end{array}$ & $\begin{array}{c}\text { Alta Velocidade na Execução } \\
\text { da Tarefa }\end{array}$ \\
\hline & $\begin{array}{l}\text { Fatores de Stress } \\
\text { Psicológicos }\end{array}$ & $\begin{array}{c}\text { Ameaças (de Falha, de Perda } \\
\text { do Emprego, etc.) }\end{array}$ \\
\hline & $\begin{array}{l}\text { Fatores de Stress } \\
\text { Psicológicos }\end{array}$ & Carga Pesada de Informações \\
\hline & $\begin{array}{l}\text { Fatores de Stress } \\
\text { Psicológicos }\end{array}$ & Início Inesperado do Stress \\
\hline & $\begin{array}{l}\text { Fatores de Stress } \\
\text { Psicológicos }\end{array}$ & $\begin{array}{c}\text { Falta de Recompensas, } \\
\text { Reconhecimento e Benefícios }\end{array}$ \\
\hline & $\begin{array}{l}\text { Fatores de Stress } \\
\text { Psicológicos }\end{array}$ & $\begin{array}{l}\text { Motivos Conflitantes sobre } 0 \\
\text { Desempenho no Trabalho }\end{array}$ \\
\hline & Fatores Externos & $\begin{array}{l}\text { Ações desenvolvidas por } \\
\text { Supervisores, Colegas, } \\
\text { Representantes de Sindicatos, } \\
\text { e Pessoal de Regulamentação }\end{array}$ \\
\hline & Fatores Externos & Capacidade Crítica da Tarefa \\
\hline & Fatores Externos & $\begin{array}{c}\text { Fatores de Interface de } \\
\text { Hardware }\end{array}$ \\
\hline & Fatores Externos & Cuidados e Advertências \\
\hline & Fatores Externos & $\begin{array}{l}\text { Freqüência e Repetitividade da } \\
\text { Tarefa }\end{array}$ \\
\hline
\end{tabular}




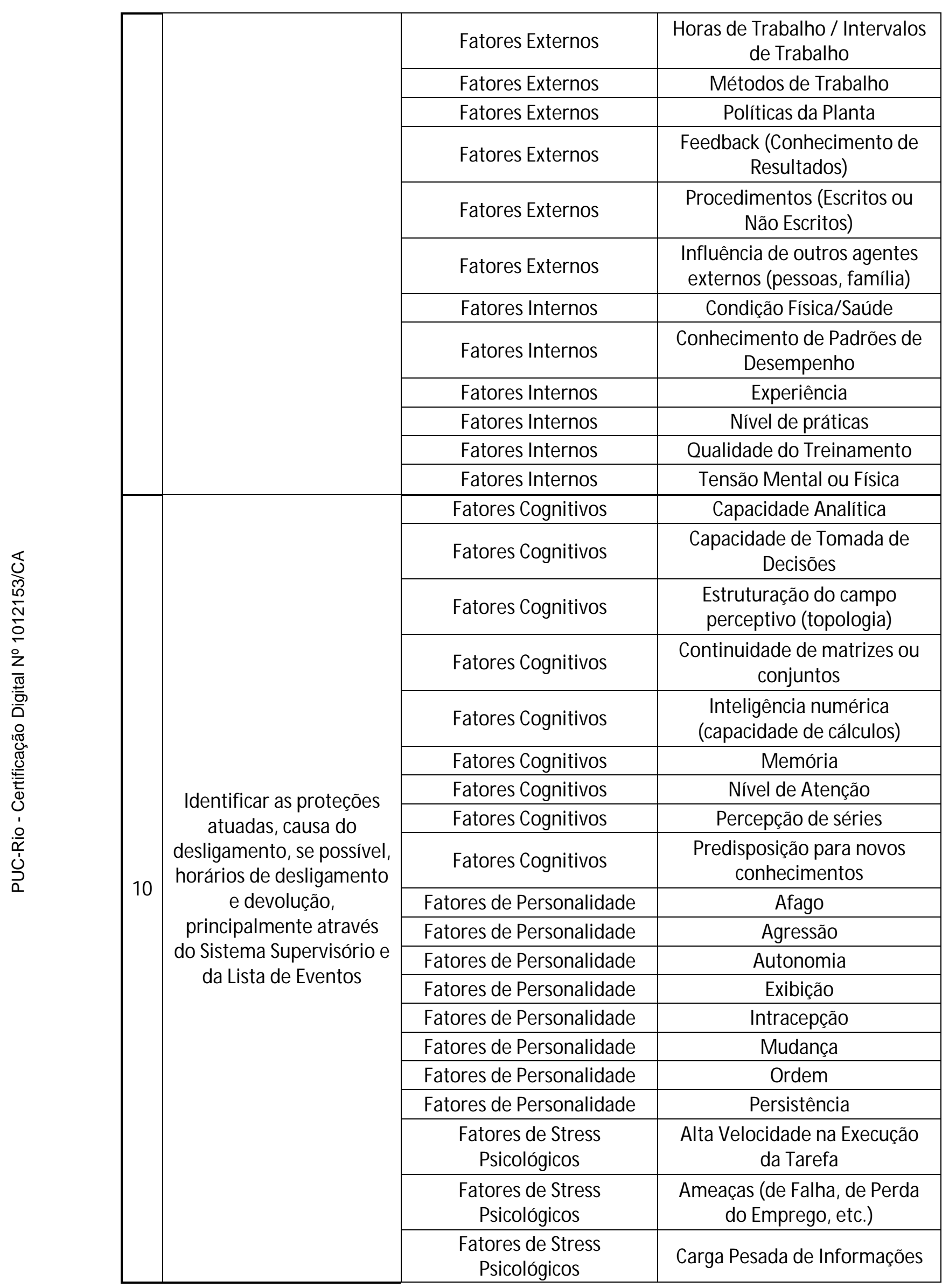




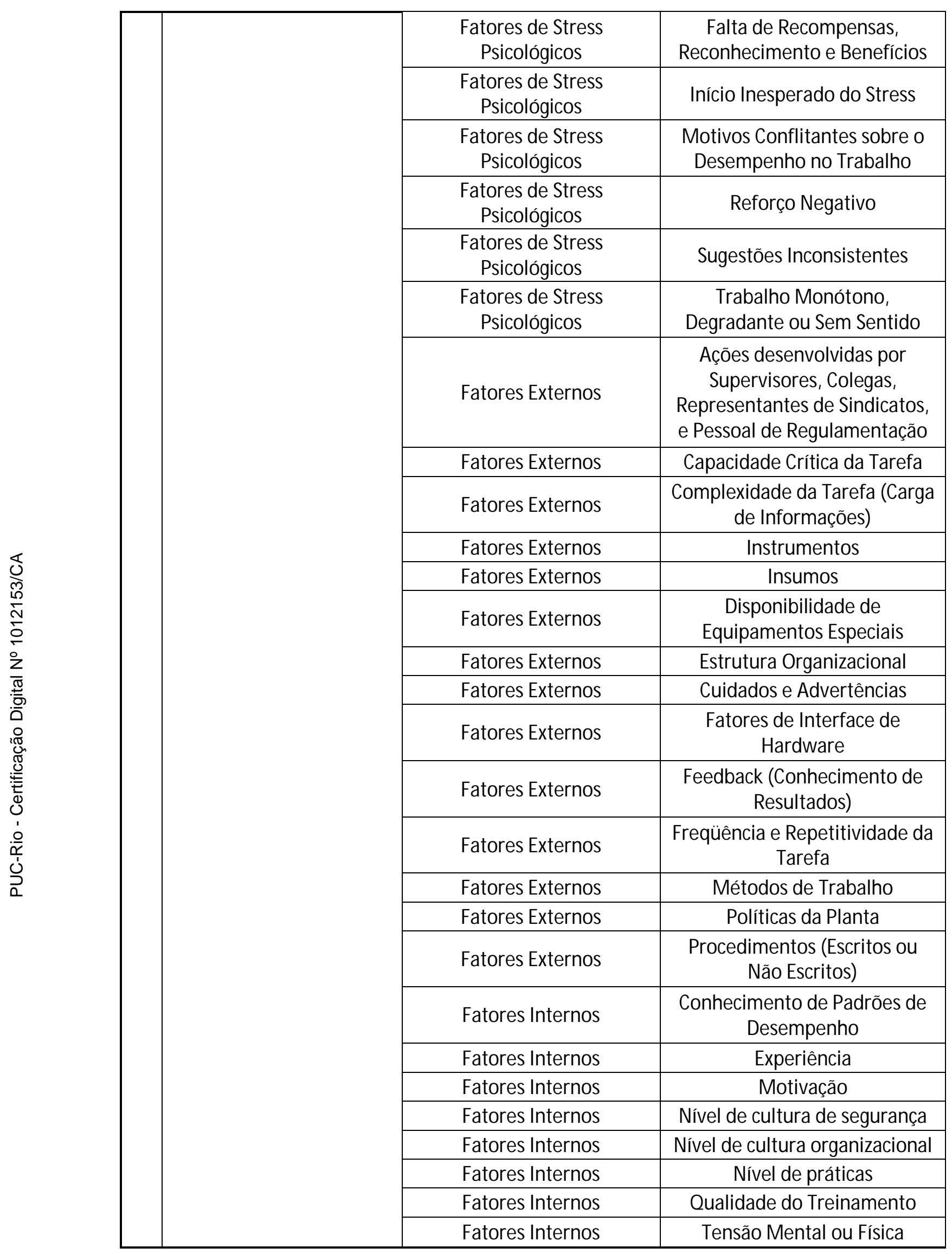

Tabela 21: Associação de tarefas do Procedimento para Recomposição com PSFs pertinentes 